SULITA MENDES PIEROTTI

\title{
AVALIAÇÃO DA PARTIDA DE REATOR ANAERÓBIO DE FLUXO ASCENDENTE E MANTA DE LODO (UASB), EM ESCALA REAL, SOB CONDIÇÕES HIDRÁULICAS DESFAVORÁVEIS.
}

Dissertação apresentada à Escola de Engenharia de São Carlos da Universidade de São Paulo, como parte dos requisitos para obtenção do Título de Mestre em Hidráulica e Saneamento.

ORIENTADOR: Prof. Dr. Jurandyr Povinelli

São Carlos 


\section{AGRADECIMENTOS}

Agradeço ao professor Jurandyr Povinelli pela valiosa oportunidade de participar da operação de uma ETE e pela confiança em mim depositada.

Às queridas amigas Thais e Silvia pela equipe que formamos. As dificuldades foram pequenas frente à nossa união. Obrigada meninas! Vocês marcaram minha vida para sempre!

Aos funcionários do SAAE - São Carlos, em especial à Isabela, Maurílio e Eduardo.

Aos professores do SHS que muito me ensinaram durante as disciplinas e aos que, além disso, participaram do desenvolvimento desta pesquisa, sempre atenciosos e apaixonados pelo seu trabalho, em especial aos professores Campos, Maria Bernadete, Woodrow e Giorgetti.

Aos técnicos do Laboratório de Saneamento: Paulo, Júlio, Juliana e Cidinha, pela amizade, paciência e horas agradáveis que passamos juntos.

Aos meus pais, Lino e Vanda. Às minhas irmãs Sara e Soraia. A meu namorado Eduardo. Todos sofreram junto a cada resultado diferente do esperado e me confortaram com sua companhia e confiança de que ao final o esforço seria recompensado.

Ao amigo Gabriel pelas preciosas observações.

À Eloísa, Beth e Janja, do LPB, por me ajudarem na desconhecida arte dos microscópios e cromatógrafos. E ao professor Heraldo Gallo do IFSC pelos ensinamentos e análise no microscópio eletrônico de varredura.

Aos funcionários do SHS, Sá, Pavi, Rose e Bruno, Flávia e Fernanda, sempre dispostos a me ajudar.

Aos responsáveis pela ETE Flores de Rio Claro - SP, que gentilmente cederam amostras de lodo para análises e posteriormente o inóculo para o reator da ETE Água Vermelha.

Ao CNPQ pela bolsa de estudo. À FAPESP pela verba de auxílio financeiro.

Aos alunos do programa de pós-graduação pela convivência e aprendizado.

Aos professores de graduação da UEL, Sandra, Deize e Fernando Fernandes, que me apresentaram o saneamento e me incentivaram a fazer o mestrado na EESC. 


\section{RESUMO}

PIEROTTI, S. M. (2007). Avaliação da partida de reator anaeróbio de fluxo ascendente e manta de lodo (UASB), em escala real, sob condições hidráulicas desfavoráveis. Dissertação (Mestrado) - Escola de Engenharia de São Carlos, Universidade de São Paulo, São Carlos.

Este estudo teve como objetivo avaliar a partida de reator anaeróbio de fluxo ascendente e manta de lodo (UASB), em escala real, no tratamento de esgoto sanitário, sob condições hidráulicas desfavoráveis. O reator UASB faz parte do sistema de tratamento da ETE Água Vermelha, e é seguido de um biofiltro aerado submerso e de uma unidade de desinfecção por ultravioleta. Foi utilizado metade do volume do reator $\left(117 \mathrm{~m}^{3}\right)$, possibilitando menor tempo de detenção hidráulica $(\mathrm{TDH})$. A pesquisa foi dividida em duas fases, uma sem a adição de inóculo (Fase I) e outra com inoculação (Fase II). Na Fase I, foram aplicados vazão de 480 m³/dia e carga orgânica volumétrica $(\mathrm{COV})$ de $1,74 \mathrm{kgDQO} / \mathrm{m}^{3}$.dia com TDH de 6 horas. Para a Fase II, estes valores foram de $600 \mathrm{~m} /$ dia, $2,88 \mathrm{kgDQO} / \mathrm{m}^{3}$.dia e 5 horas. Os resultados mostraram que as excessivas velocidades ascensionais não permitiram que o reator tivesse desempenho satisfatório. Ocorreu remoção de matéria orgânica e sólidos suspensos apenas na Fase II, com exceção dos sólidos suspensos voláteis, que apresentaram remoção nas duas fases. Os lançamentos indevidos de lodo de fossas à que a ETE está submetida, provocaram aumento de sólidos dissolvidos e alcalinidade no efluente. Os leitos de lodo formados nas fases I e II possuíam concentrações semelhantes de sólidos, porém o segundo apresentou maior eficiência de tratamento. Na Fase I a remoção de matéria orgânica foi pequena e não ocorreu a formação da manta de lodo. Na Fase II ocorreu o provável início da estabilização do processo, aproximadamente 60 dias após a inoculação, a partir de quando a remoção de matéria orgânica dissolvida foi considerada constante e foi observada a formação da manta de lodo. $\mathrm{O}$ descarte de $8,5 \mathrm{~m}^{3}$ de lodo pode ser feito a cada 30 dias.

Palavras chaves: Partida de UASB, ETE, sobrecarga hidráulica, digestão de lodo aeróbio. 


\begin{abstract}
PIEROTTI, S. M. (2007). Start-up of a full-scale upflow anaerobic sludge blanket (UASB) reactor, treating domestic sewage, under unfavorable hydraulic conditions. M.Sc. Dissertation - Escola de Engenharia de São Carlos, Universidade de São Paulo, São Carlos.

The objective of this study was to evaluate the start-up of a full-scale upflow anaerobic sludge blanket (UASB) reactor, treating domestic sewage, under unfavorable hydraulic conditions. The UASB reactor is part of the wastewater treatment plant of Água Vermelha (São Carlos, SP, Brazil), and it is followed by a submerged aerated biofilter and an ultraviolet radiation disinfection unit. Half of the reactor volume was used $\left(117 \mathrm{~m}^{3}\right)$, making it possible to work with a low hydraulic retention time (HRT). The research was divided in two phases, one without reactor seeding (Phase I), and another when the reactor was seeded (Phase II). At Phase I, a flow rate of $480 \mathrm{~m}^{3} / \mathrm{d}$ and a volumetric loading rate of $1,74 \mathrm{kgDQO} / \mathrm{m}^{3}$.d were applied, with 6 hours of HRT. At Phase II, this values were $600 \mathrm{~m}^{3} / \mathrm{d} ; 2,88 \mathrm{kgDQO} / \mathrm{m}^{3} \mathrm{~d}$ and 5 hours. The results showed that excessive upflow velocities prevented satisfactory performance of the reactor. Removal efficiencies of COD, BOD and TSS were obtained only in Phase II, except for VSS, which showed removal in both stages. Unauthorized inputs of septic tanks sludge caused increase in dissolved solids and alkalinity in the effluent. The sludge beds obtained in phases I and II had similar solids concentration; however, the second presented better treatment efficiency. At Phase I, organic matter removal efficiency was low and the blanket sludge was not observed. At Phase II, the process likely stabilized 60 days after inoculation (operations' day 240). From then on, dissolved organic matter digestion was constant and the sludge blanket was observed. The removal of the excess sludge can be done every other 30 days.
\end{abstract}

Keywods: UASB's start-up, WWTP, hydraulic overload, aerobic sludge digestion 


\section{LISTA DE FIGURAS}

Figura 1 - Balanço da DQO (porcentagem representativa para reatores UASB com TDH de 8h). Fonte: Lettinga (1989) apud Carrasco (1992). ............................................. 24

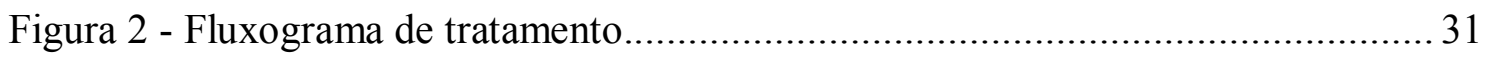

Figura 3 - Tratamento preliminar da ETE Água Vermelha. ........................................ 32

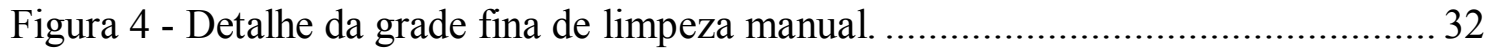

Figura 5 - Detalhe da caixa de areia e o medidor de vazão tipo Parshall. ...................... 33

Figura 6 - Reatores UASB e BAS e as válvulas de lavagem. ................................... 34

Figura 7 - Vista geral da câmara de desinfecção por UV . ........................................... 35

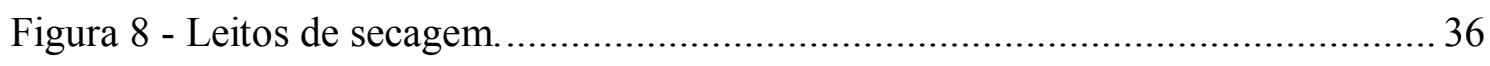

Figura 9 - Corte esquemático do reator UASB - Fonte: Kellner (2003)..................... 37

Figura 10 - Tubulação de recalque e caixa distribuidora de vazão............................... 37

Figura 11 - Caixa distribuidora de vazão e vertedor de entrada................................. 38

Figura 12 - Vertedores e tubulação que conduz ao fundo do reator............................ 38

Figura 13 - Tubulação de gás, queimador, amostrador de lodo e válvulas de descarte de lodo.

Figura 14 - Disposição das tulipas coletoras do efluente tratado, parte superior e lateral da câmara de gás e parede inclinada do separador de fases.

Figura 15 - Mangote do caminhão limpa-fossas preso à parte superior do reator e vista geral do caminhão e reator durante a inoculação.

Figura 16 - Pontos de coleta e materiais utilizados.

Figura 17 - Amostras prontas para receber o banho de ouro antes da observação......... 52

Figura 18 - Vista geral do by-pass instalado na estação elevatória............................... 58

Figura 19 - Vista externa (a) e interna (b) da estação elevatória. ................................ 58

Figura 20 - Hidrograma de vazão do UASB em 13/07/2006 (156 dia de operação - Fase

I), com bom funcionamento do by-pass.

Figura 21 - Hidrograma de vazão do UASB em 15 e 16/08/2006 (190 dia de operação Fase II), com by-pass possivelmente entupido. 60

Figura 22 - Exemplo do hidrograma mais comumente observado na entrada do UASB com picos elevados de pequena duração, dia 211 de operação - Fase II (12/09/2006). 61 Figura 23 - Exemplo de hidrograma com comportamento diferente do mais comumente observado na entrada do UASB, dia 197 de operação - Fase II (22/08/2006). 61 
Figura 24 - Exemplo de hidrograma com comportamento diferente do mais comumente observado na entrada do UASB, dia 204 de operação - Fase II (04/09/2006).

Figura 25 - Produção de metano ao longo do teste de AME do inóculo utilizando acetato como substrato.

Figura 26 - Atividade metanogênica específica do inóculo, utilizando acetato como substrato.

Figura 27 - Produção de metano ao longo do teste de AME do inóculo, com esgoto como substrato.

Figura 28 - Atividade metanogênica específica do inóculo, utilizando esgoto como substrato.

Figura 29 - Atividade metanogênica específica para o leito de lodo, no fim do experimento, utilizando esgoto como substrato.

Figura 30 - Atividade metanogênica específica para o leito de lodo, no fim do experimento, utilizando acetato como substrato. 65

Figura 31 - Fotomicrografias de morfologias semelhantes Methanosarcina sp. em foto comum (a) e com fluorescência (b). 66

Figura 32 - Filamentos semelhantes à Methanosaeta sp. 66

Figura 33 - Fotomicrografias de algumas morfologias presentes no reator no dia 225 de operação. Morfologias semelhantes a Methanosaeta e bacilos (a) e feixes de morfologias semelhantes a Methanosaeta (b).

Figura 34 - Fotomicrografias de morfologias semelhantes a Methanosaeta sp. 68

Figura 35 - Fotomicrografias de algumas morfologias presentes no leito de lodo no dia 280 de operação. Bacilos com inclusões (a) e cadeia de cocos (b). 68

Figura 36 - Desenvolvimento de algas no tanque pulmão. 69

Figura 37 - Algas procedentes no tanque pulmão no reator UASB.

Figura 38 - Fotomicrografia de algumas morfologias presentes no leito de lodo $(0,85 \mathrm{~m})$ no dia 280 de operação. (a) Bacilos semelhantes a bactérias fototróficas anoxigênicas e morfologias semelhantes a Methanosaeta sp., bacilos e vibrios. 70

Figura 39 - Feixe de morfologias semelhantes a Methanosaeta sp. (a) e morfologias isoladas semelhantes a Methanosaeta sp. e bacilos (b).

Figura 40 - Comparação da DQO bruta afluente nas segundas-feiras, entre 8 e 13 horas, em função do dia de operação. 72

Figura 41 - Comparação da DQO bruta efluente nas segundas-feiras, entre 8 e 13 horas, em função do número de amostras. 
Figura 42 - Comparação da DQO bruta afluente nas terças-feiras, entre 8 e 13 horas, em função dos dias de operação.

Figura 43 - Comparação da DQO bruta efluente nas terças-feiras, entre 8 e 13 horas, em função dos dias de operação.

Figura 44 - Comparação da DQO bruta afluente, entre $2^{\mathrm{a}}$ e $3^{\mathrm{a}}$ feira, para o período das 8 às 10 horas.

Figura 45 - Comparação da DQO bruta afluente, entre $2^{\mathrm{a}}$ e $3^{\mathrm{a}}$ feira, para o período das 10 às 12 horas.

Figura 46 - Comparação da DQO bruta afluente, entre $2^{\mathrm{a}}$ e $3^{\mathrm{a}}$ feira, para o período das 12 às 13 horas.

Figura 47 - Comparação da DQO bruta efluente, entre $2^{\mathrm{a}}$ e $3^{\mathrm{a}}$ feira, para o período das 8 às 10 horas. 76

Figura 48 - Comparação da DQO bruta efluente, entre $2^{\mathrm{a}}$ e $3^{\mathrm{a}}$ feira, para o período das 10 às 12 horas. 76

Figura 49 - Comparação da DQO bruta efluente, entre $2^{\mathrm{a}}$ e $3^{\mathrm{a}}$ feira, para o período das 12 às 13 horas.

Figura 50 - Variação de DQO bruta afluente e efluente ao longo do tempo 79

Figura 51 - Variação da concentração de sólidos totais e DQO bruta afluente e efluente.

Figura 52 - Variação da concentração de sólidos totais fixos afluente e efluente. 81

Figura 53 - Variação da concentração de sólidos totais voláteis afluente e efluente. .... 81

Figura 54 - Variação das concentrações afluente e efluente de sólidos suspensos totais 82 Figura 55 - Variação das concentrações afluente e efluente de sólidos suspensos fixos.

Figura 56 - Variação das concentrações afluente e efluente.de sólidos suspensos voláteis

Figura 57 - Variação das concentrações afluente e efluente de sólidos dissolvidos totais ao longo do tempo. 84

Figura 58 - Variação das concentrações afluente e efluente de sólidos dissolvidos fixos ao longo do tempo.

Figura 59 - Variação das concentrações afluente e efluente de sólidos dissolvidos voláteis ao longo do tempo.

Figura 60 - Variação da concentração de sólidos no leito de lodo $(0,25 \mathrm{~m}$ de altura).... 86

Figura 61 - Variação da concentração de sólidos a $0,85 \mathrm{~m}$ de altura. 86 
Figura 62 - Variação da concentração de sólidos a 1,45 m de altura. 87

Figura 63 - Variação da concentração de sólidos a 2,05 m de altura. 87

Figura 64 - Variação da concentração de sólidos a 2,65 m de altura. .87

Figura 65 - Variação da concentração de sólidos a 3,25 m de altura. 88

Figura 66 - Variação da concentração de sólidos a 3,85 m de altura. 89

Figura 67 - Variação dos sólidos sedimentáveis a ao longo da altura do reator. 89

Figura 68 - Perfil de sólidos totais e voláteis no reator, com 60 dias de operação da Fase

I, sem inóculo e com 60 dias de operação Fase II, com inoculação. 90

Figura 69 - Perfil de sólidos totais e voláteis no reator, na da Fase II - 97 dias de operação com inóculo (a) antes do descarte e no final da Fase II - 104 dias de operação, após o descarte de $8,5 \mathrm{~m}^{3}$ de lodo do UASB (b). ................................................. 91

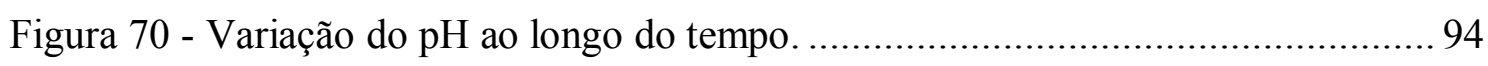

Figura 71 - Variação de alcalinidade total e parcial ao longo do tempo........................ 95

Figura 72 - Variação dos ácidos voláteis afluentes ao longo do tempo........................ 97

Figura 73 - Variação dos ácidos voláteis efluentes ao longo do tempo........................ 97

Figura 74 - Variação da concentração de nitrogênio total Kjeldahl e nitrogênio amoniacal ao longo do tempo. 98

Figura 75 - Variação da concentração de nitrogênio orgânico ao longo do tempo e eficiência de remoção 99

Figura 76 - Variação da concentração de nitrato ao longo do tempo. 99

Figura 77 - Variação da concentração de nitrito ao longo do tempo. 100

Figura 78 - Cesto instalado na caixa distribuidora de vazão do reator UASB. 106 


\section{LISTA DE TABELAS}

Tabela 1 - Composição típica do esgoto bruto doméstico.

Tabela 2 - Eficiências de remoção de DQO e DBO em (\%) para diferentes temperaturas.

Tabela 3 - Condições operacionais e eficiências médias de remoção em reator UASB. 11

Tabela 4 - Eficiências de remoção de DQO em UASB.

Tabela 5 - Variação da concentração de sólidos na manta de lodo e massa de sólidos acumulada......

Tabela 6 - Características dos lodos de fossas sépticas. 30

Tabela 7 - Características operacionais de projeto e das Fases I e II da pesquisa.

Tabela 8 - Características físico-químicas do efluente da TAM adicionado ao reator no início da Fase I.

Tabela 9 - Parâmetros físico-químicos e pontos de amostragem.

Tabela 10 - Valores médios de DQO, nos três períodos do dia observados e seus respectivos desvios-padrões.

Tabela 11 - Valores médios, mínimos e máximos e o número de dados analisados (n) do parâmetro SS e respectiva eficiência durante as fases I e II

Tabela 12 - Porcentagem de sólidos em massa (\% STV/ST) para as alturas de 0,25 m, 0,85 m e 1,45 m para 80 dias de operação da Fase I, 60 dias de operação da Fase II e final do experimento.

Tabela 13 - Concentrações médias de sólidos no lodo de lavagem do biofiltro aerado submerso

Tabela 14 - Valores médios da produção diária de lodo em relação à DQO aplicada em $\mathrm{kgSST} /$ dia, do coeficiente de sólidos observado em $\mathrm{kgSST} / \mathrm{kgDQOaplicada} \mathrm{e}$ respectivos valores de projeto esperados.

Tabela 15 - Valores das concentrações em mg/L de metais pesados para a ETE Água Vermelha.

Tabela 16 - Valores das concentrações em $\mathrm{mg} / \mathrm{L}$ de metais pesados para o perfil do reator UASB.

Tabela 17 - Valores do parâmetro K de Mosey para o reator UASB. 103

Tabela 18 - Eficiências globais de remoção em \% da ETE Água Vermelha em função das análises de DBO afluente e efluente. 


\section{LISTA DE SIGLAS}

BAS - Biofiltro aerado submerso

BRS - Bactérias redutoras de sulfato

CETESB - Companhia de Tecnologia de Saneamento Ambiental

EE - Estação elevatória

EESC - Escola de Engenharia de São Carlos

ETE - Estação de Tratamento de Esgotos

IFSC - Instituto de Física de São Carlos

IPT - Instituto de pesquisas tecnológicas de São Paulo

LPB - Laboratório de processos biológicos

PROSAB - Programa de Pesquisa em Saneamento Básico

RALF - Reator anaeróbio de leito fluidizado

SAAE - Serviço Autônomo de Água e Esgoto

SANEPAR - Companhia de Saneamento do Paraná

TAM - Transportes Aéreos Regionais

UASB - Sigla em inglês para reator anaeróbio de fluxo ascendente e manta de lodo

(Upflow Anaerobic Sludge Blanket)

UFMG - Universidade Federal de Minas Gerais

USP - Universidade de São Paulo

UV - Reator de desinfecção por ultravioleta 


\section{LISTA DE SÍMBOLOS}

AGV - Ácidos graxos voláteis

AME - Atividade metanogênica específica

COT - Carbono orgânico total

COTf - Carbono orgânico total medido em amostra filtrada

COV - Carga orgânica volumétrica

DBO - Demanda bioquímica de oxigênio

DQO - Demanda química de oxigênio

$\mathrm{DQO}_{\mathrm{CH} 4 \text { diss. }}$ - Demanda química de oxigênio do metano dissolvido no líquido

DQOa - Demanda química de oxigênio afluente

DQOaplic - Demanda química de oxigênio aplicada

$\mathrm{DQO}_{\mathrm{CH} 4}$ - Demanda química de oxigênio do metano

DQOe - Demanda química de oxigênio efluente

DQOf - Demanda química de oxigênio medida em amostra filtrada

DQOlodo - Demanda química de oxigênio do lodo

DQOremov - Demanda química de oxigênio removida

gDQOcons. - Gramas de DQO consumida

MEV - Microscopia eletrônica de varredura

OG - Óleos e graxas

SDT - Sólidos dissolvidos totais

SS - Sólidos sedimentáveis

SST - Sólidos suspensos totais

SSV - Sólidos suspensos voláteis

ST - Sólidos totais

TDH - Tempo de detenção hidráulica 
Yobs - coeficiente de produção de sólidos observado

Өc - Tempo de retenção celular ou idade do lodo 


\section{SUMÁRIO}

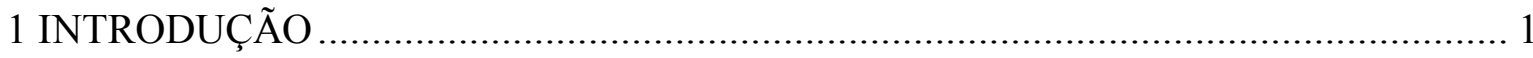

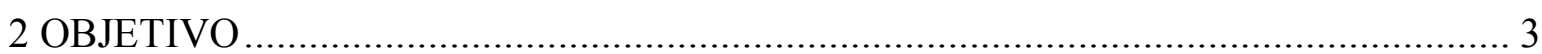

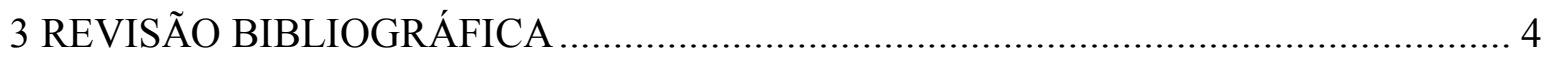

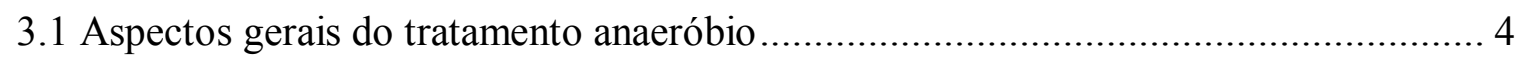

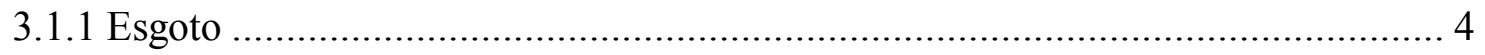

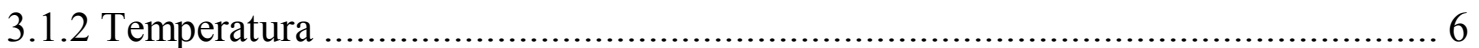

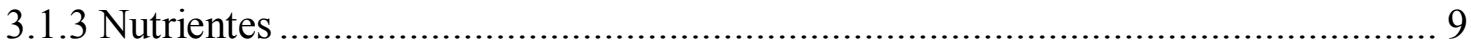

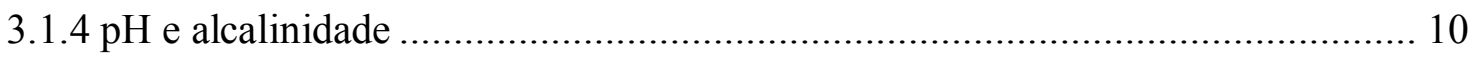

3.1.5 Sobrecargas hidráulicas ........................................................................ 10

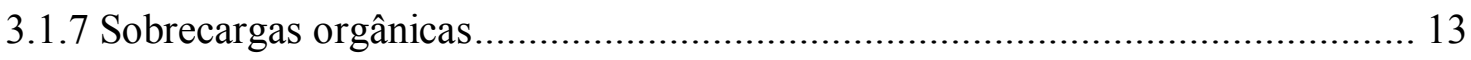

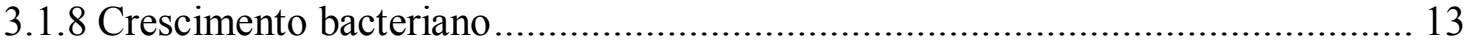

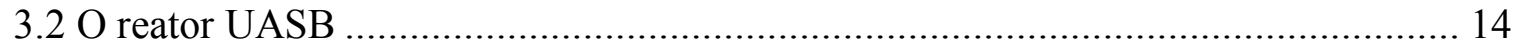

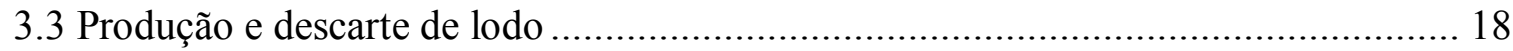

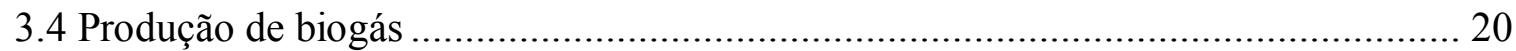

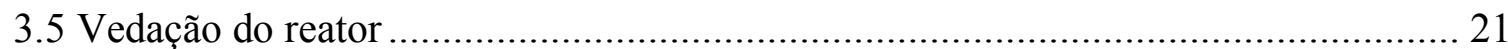

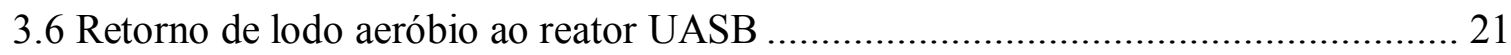

3.7 Balanço de massa em reator UASB ................................................................. 23

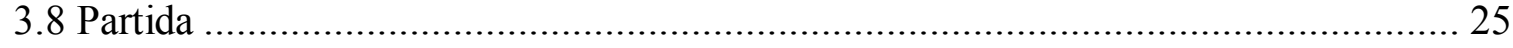

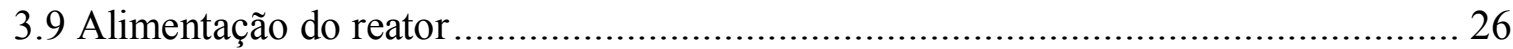

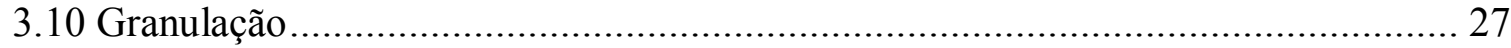

3.11 Disposição de lodo de fossas sépticas em estações de tratamento de esgoto........... 29

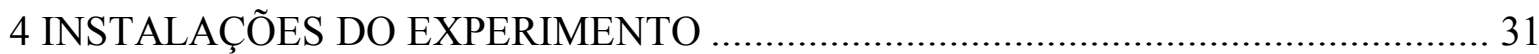

5 PROCEDIMENTOS EXPERIMENTAIS............................................................ 41

5.1 Características operacionais das fases I e II da pesquisa ..................................... 41

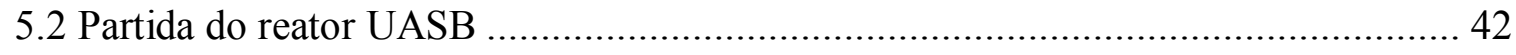

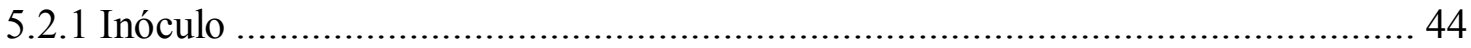

5.3 Avaliação dos parâmetros físico-químicos ............................................................ 46

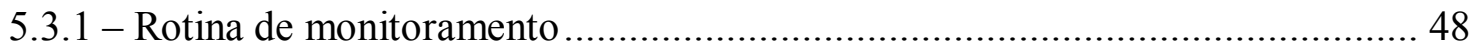

5.3.2 - Cromatografia a gás para ácidos voláteis ................................................ 49

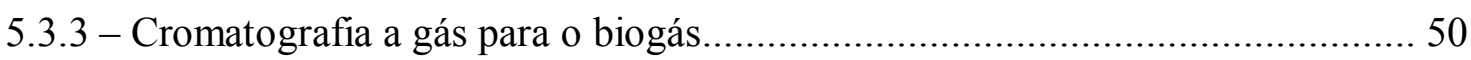

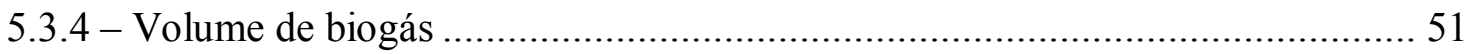

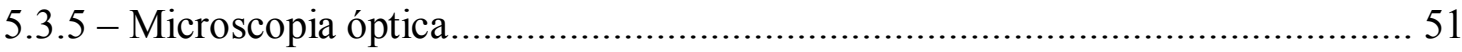


5.3.6 - Microscopia eletrônica de varredura............................................................. 51

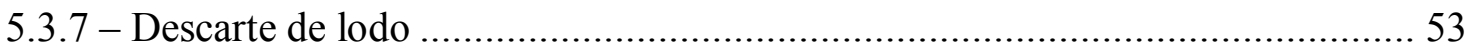

5.3 .8 - Retorno de lodo do BAS para o UASB ..................................................... 53

5.3.9 - Lançamento de lodo de fossas na ETE Água Vermelha ................................ 53

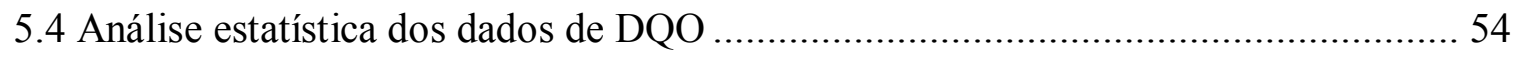

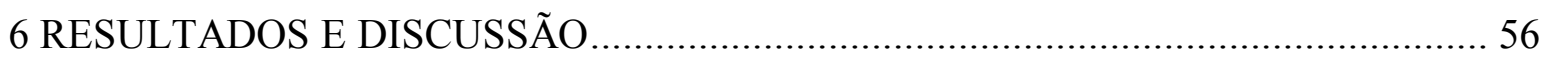

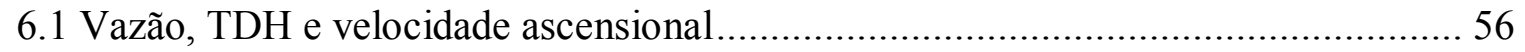

6.2 Teste de atividade metanogênica no inóculo e no lodo ao término do experimento.. 62

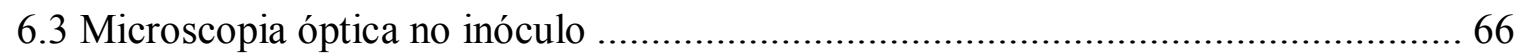

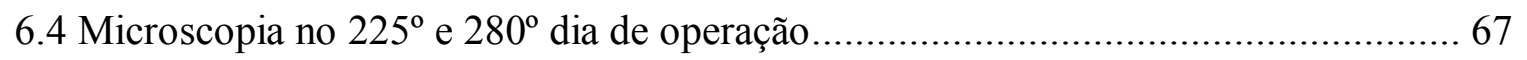

6.5 Microscopia eletrônica de varredura (MEV)...................................................... 70

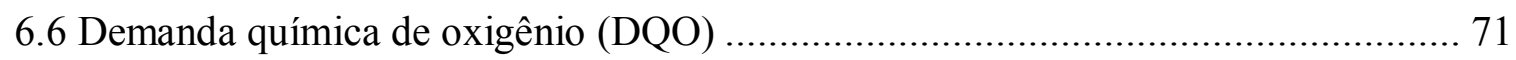

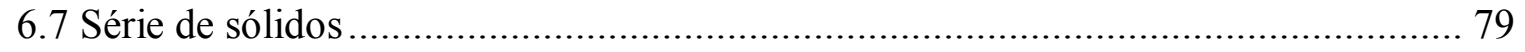

6.8 Caracterização do lodo do BAS recirculado para o UASB ...................................... 92

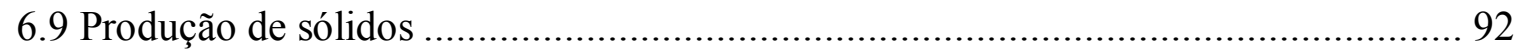

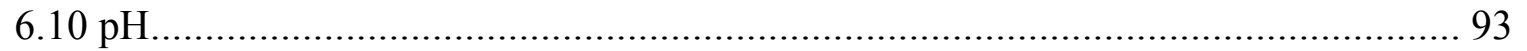

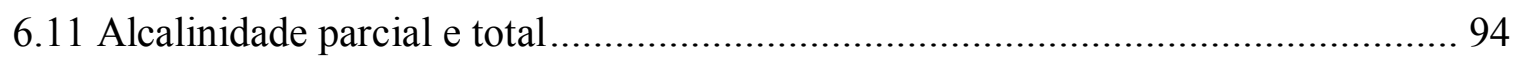

6.12 Relação entre Demanda Bioquímica de Oxigênio (DBO), DQO e Carbono

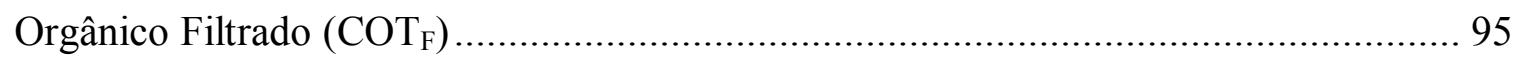

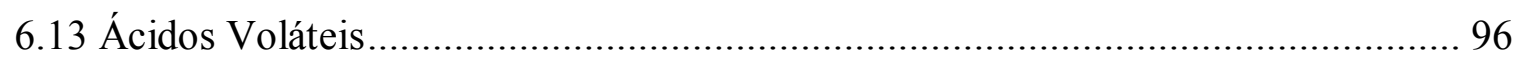

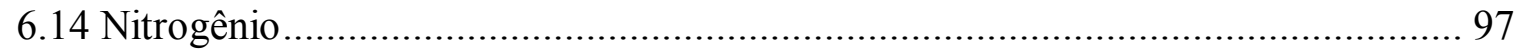

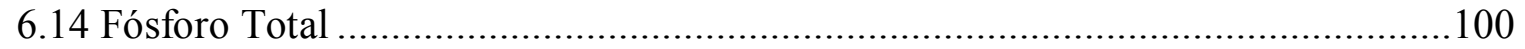

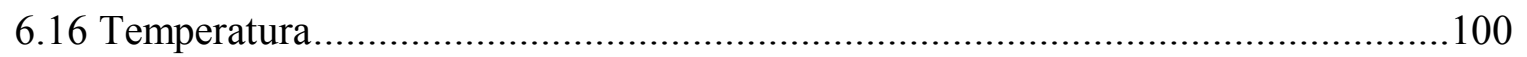

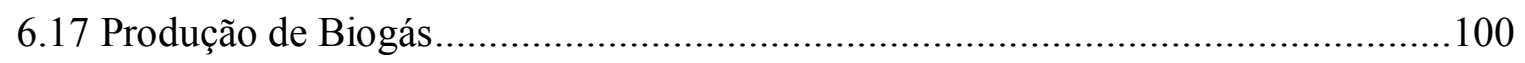

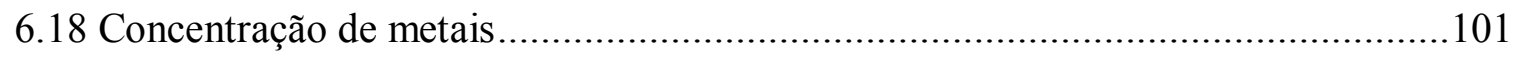

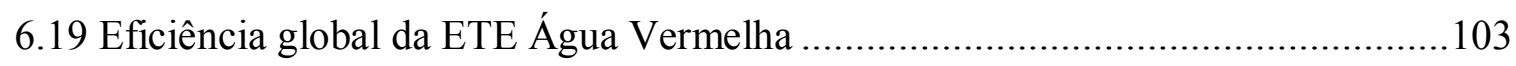

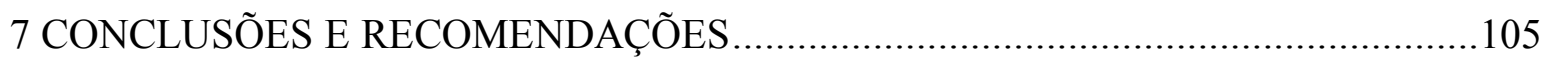

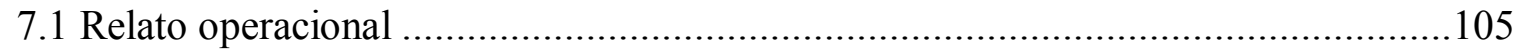

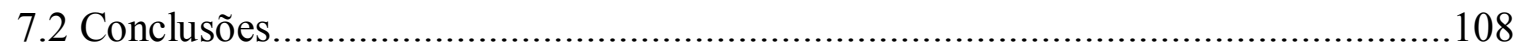

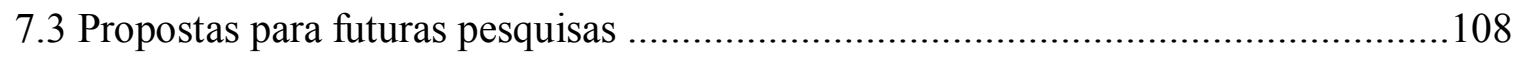

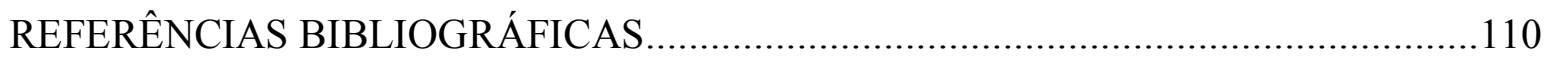

ANEXO A - Valores dos parâmetros físico-químicos...............................................118

ANEXO B - Análise estatística da demanda química de oxigênio (DQO) .......................128

ANEXO C - Teste de Atividade Metanogênica Específica...........................................137 
ANEXO D - Adensamento do lodo do UASB. 


\section{INTRODUÇÃO}

Esta pesquisa foi desenvolvida na Estação de Tratamento de Esgotos (ETE) Água Vermelha, situada no distrito de Água Vermelha, em São Carlos (SP), na subbacia do ribeirão Araras, afluente do rio Mogi-Guaçu. O distrito de Água Vermelha possuía em 2003 aproximadamente 630 habitantes, dez unidades comerciais e três industriais, sendo uma de fabricação de artefatos de cimento e duas unidades de uma indústria de fabricação de peças metálicas (KELLNER, 2003).

Também é atendida unidade da empresa TAM - Transportes Aéreos Regionais, com aproximadamente 800 funcionários, sendo, porém, tratados apenas seus efluentes domésticos, cuja vazão corresponde a aproximadamente $30 \%$ da vazão total afluente à ETE.

Até pouco tempo atrás, a ETE operava com sistema de grade fina, caixa de areia e dois conjuntos de lagoas de estabilização no sistema australiano (lagoa anaeróbia seguida de lagoa facultativa), com Licença de Funcionamento a Título Precário, por não atender aos padrões vigentes de lançamento. No início de 2003, a empresa TAM e o SAAE (Serviço Autônomo de Água e Esgoto) de São Carlos iniciaram conversação para estabelecimento de parceria que possibilitasse a reforma e ampliação da ETE.

A ETE Água Vermelha é agora constituída de grade fina de limpeza manual; caixa de areia; medidor de vazão tipo Parshall; poço pulmão; reator anaeróbio de manta de lodo (UASB - Upflow Anaerobic Sludge Blanket); biofiltro aerado submerso (BAS); dispositivo de desinfecção dos esgotos por ultravioleta (UV); leito de secagem de lodo e escada hidráulica. 
A adoção de pós-tratamento se faz necessária devido às características do efluente de reatores UASB geralmente não atenderem aos padrões da legislação ambiental (CHERNICHARO, 1997). As tecnologias de pós-tratamento de efluentes anaeróbios que se encontram, atualmente, mais consolidadas são a disposição final no solo, lagoas de polimento, reatores com biofilme, lodos ativados, flotação e desinfecção (CHERNICHARO et al, 2001).

Três pesquisas de mestrado, uma para o reator UASB (o presente trabalho), uma para o BAS e outra para a desinfecção por UV, monitoraram a ETE ao longo de 2006, junto ao SAAE São Carlos.

A oportunidade de acompanhar a ETE Água Vermelha desde sua partida possibilitou novos dados de desempenho em escala real que serão úteis como futuros parâmetros de projeto e procedimentos de partida de reatores UASB. 


\section{OBJETIVO}

O objetivo desta pesquisa foi avaliar a partida de reator UASB em escala real, tratando esgoto sanitário sob condições hidráulicas desfavoráveis, com e sem a adição de inóculo. 


\section{REVISÃO BIBLIOGRÁFICA}

\subsection{Aspectos gerais do tratamento anaeróbio}

\subsubsection{Esgoto}

Metcalf \& Eddy (2003) caracterizam o esgoto bruto doméstico, de acordo com a concentração dos constituintes físico-químicos, em concentração elevada, média ou baixa (Tabela 1).

Tabela 1 - Composição típica do esgoto bruto doméstico.

\begin{tabular}{llll}
\hline \multirow{2}{*}{ CONSTITUINTE } & \multicolumn{2}{l}{ CONCENTRAÇÃO $(\mathrm{mg} / \mathrm{L})$} \\
\cline { 2 - 4 } & Elevada & Média & Baixa \\
\hline Sólidos Totais & 1200 & 720 & 350 \\
Sólidos Dissolvidos Totais & 850 & 500 & 250 \\
Sólidos Dissolvidos Fixos & 525 & 300 & 145 \\
Sólidos Dissolvidos Voláteis & 325 & 200 & 105 \\
Sólidos Suspensos Totais & 350 & 220 & 100 \\
Sólidos Suspensos Fixos & 75 & 55 & 20 \\
Sólidos Suspensos Voláteis & 275 & 165 & 80 \\
Sólidos Sedimentáveis (mL/L) & 20 & 10 & 5 \\
DBO & 400 & 220 & 110 \\
COT & 290 & 160 & 80 \\
\hline
\end{tabular}


Tabela 1: Composição típica do esgoto bruto doméstico.

\begin{tabular}{|c|c|c|c|}
\hline DQO & 1000 & 500 & 250 \\
\hline Nitrogênio Total & 85 & 40 & 20 \\
\hline Nitrogênio Orgânico & 35 & 15 & 8 \\
\hline Nitrogênio Amoniacal & 50 & 25 & 12 \\
\hline Nitritos & 0 & 0 & 0 \\
\hline Nitratos & 0 & 0 & 0 \\
\hline Fósforo Total & 15 & 8 & 4 \\
\hline Fósforo Orgânico & 5 & 3 & 1 \\
\hline Fósforo Inorgânico & 10 & 5 & 3 \\
\hline Cloretos $^{1}$ & 100 & 50 & 30 \\
\hline Alcalinidade como $\mathrm{CaCO}_{3}{ }^{1}$ & 200 & 100 & 50 \\
\hline Óleos e Graxas & 150 & 100 & 50 \\
\hline
\end{tabular}

Fonte: Metcalf \& Eddy (2003).

${ }^{1}$ Dependendo do sistema de abastecimento de água.

Pode-se distinguir na conversão anaeróbia de matéria orgânica quatro etapas: hidrólise, acidogênese, acetogênese e metanogênese.

Hidrólise: processo no qual a matéria orgânica particulada é convertida em compostos dissolvidos de massa molecular mais baixa. Aqui são necessárias exoenzimas produzidas pelas bactérias fermentativas, que degradam proteínas a aminoácidos, carboidratos a mono e dissacarídeos e convertem lipídeos a ácidos graxos de cadeia longa e glicerina. Esta etapa pode ser considerada limitante no processo de digestão anaeróbia, pois sua velocidade é usualmente menor que a das demais etapas de conversão.

Acidogênese: a fermentação acidogênica é realizada por grupo diversificado de bactérias, a maioria anaeróbia obrigatória. Neste processo, os produtos da hidrólise são utilizados pelas bactérias fermentativas, as quais excretam substâncias orgânicas simples (ácidos graxos voláteis de cadeia curta - AGV, álcoois e ácido lático, além de compostos minerais como $\mathrm{CO}_{2}, \mathrm{H}_{2}, \mathrm{NH}_{3}, \mathrm{H}_{2} \mathrm{~S}$, entre outros). Porém, existem também espécies facultativas, com grande importância devido à sua capacidade de consumir o oxigênio dissolvido, às vezes presente, que seria tóxico para as anaeróbias estritas.

Acetogênese: neste processo os produtos da acidogênese são convertidos a acetato, hidrogênio e dióxido de carbono pelas bactérias acetogênicas. 
Metanogênese: aqui os produtos da acetogênese são utilizados pelas arquéias metanogênicas acetoclásticas (fermentam o ácido acético) e hidrogenotróficas (reduzem o dióxido de carbono). No caso do sistema não conter oxigênio, mas oxidantes alternativos como o nitrato e o sulfato, podem ocorrem respectivamente processos de desnitrificação $\left(\mathrm{NO}_{3}\right.$ levado a $\left.\mathrm{N}_{2}\right)$, e de redução de sulfato. Este último é geralmente indesejável, pois as bactérias redutoras de sulfato (BRS) competem pelo substrato com as arquéias metanogênicas, diminuindo a produção de metano, além de formar gás sulfídrico, que é corrosivo, confere odor desagradável e pode também ser tóxico à metanogênese. No entanto, a redução anaeróbia de sulfato pode ser interessante quando se visa à remoção deste íon para reúso do efluente em processo industrial, além de auxiliar no controle da toxicidade por metais pesados devido à baixa solubilidade dos compostos formados por estes e os sulfetos.

Dentre os fatores ambientais que influenciam o desempenho da digestão anaeróbia, segundo Foresti et al. (1999), estão: temperatura, nutrientes, pH, alcalinidade, sobrecargas hidráulicas e orgânicas e o crescimento bacteriano.

\subsubsection{Temperatura}

A coleta de dados tem demonstrado que até $28{ }^{\circ} \mathrm{C}$ de temperatura do ar, aproximadamente, a temperatura do esgoto é geralmente um pouco superior à temperatura ambiente, mesmo no inverno, uma vez que o esgoto gerado nas casas é levemente aquecido e escoa protegido por uma tubulação enterrada. Acima desse valor a situação se inverte (JORDÃO \& PESSOA, 2005).

A temperatura altera a velocidade do metabolismo microbiano, o equilíbrio iônico e a solubilidade dos substratos (especialmente lipídeos abaixo de $20^{\circ} \mathrm{C}$ ). $\mathrm{Na}$ faixa de temperatura entre $20^{\circ} \mathrm{C}$ e $25^{\circ} \mathrm{C}$, a velocidade específica de utilização de substrato é a metade da atingida a $35^{\circ} \mathrm{C}$. É importante lembrar que a velocidade global de remoção do substrato está associada também à concentração de microrganismos ativos.

A temperatura é um fator ambiental de extrema importância em qualquer processo biológico, tendo influência nas atividades metabólicas da população microbiana, inibindo ou favorecendo seu crescimento (CARRASCO, 1992).

Singh \& Viraraghavan (2003) estudaram a viabilidade de tratamento de esgotos municipais em reator UASB, de aproximadamente $1 \mathrm{~m}^{3}$, a temperaturas de 32, 20, 15, 11 e $6{ }^{\circ} \mathrm{C}$, aplicando vários $\mathrm{TDHs}$ entre 48 e 3 horas, durante aproximadamente 900 
dias. Após 20 dias da partida foi atingida remoção entre 40 e 60 \% para DQO. A partida durou em torno de 60 dias, atingindo então eficiência de 80 a $85 \%$ de remoção de DQO. Para TDH de 6 horas, acima de $11{ }^{\circ} \mathrm{C}$, o reator apresentou boas eficiências de remoção. Quando o TDH foi reduzido para 4 e 3 horas houve decréscimo de remoção. Similarmente, quando a temperatura foi reduzida de 11 para $6{ }^{\circ} \mathrm{C}$ o reator exibiu condições instáveis, ocorrendo quedas de remoção de DQO e DBO para 30 a 40 \%. Foi observado que no TDH de 3 horas, para as temperaturas de 20 e $30^{\circ} \mathrm{C}$, houve aumento dos sólidos suspensos no efluente, possivelmente devido ao aumento da velocidade ascensional. Em todas as temperaturas estudadas, exceto a $6{ }^{\circ} \mathrm{C}$, houve 80 a $90 \%$ de eficiência de remoção de SS, mostrando que a temperatura não afeta significativamente a remoção de SS. Este bom desempenho é atribuído aos grânulos de lodo existentes no leito de lodo. A Tabela 2 mostra as eficiências de remoção de DQO e DBO para diferentes temperaturas encontradas no estudo de Singh \& Viraraghavan (2003).

Tabela 2 - Eficiências de remoção de DQO e DBO em (\%) para diferentes temperaturas.

\begin{tabular}{lll}
\hline $\begin{array}{l}\text { Temperatura } \\
\left({ }^{\circ} \mathrm{C}\right)\end{array}$ & Efic. remoção de DQO & Efic. remoção de DBO \\
\hline 6 & 60 & 58 \\
11 & 79 & 75 \\
15 & 81 & 79 \\
20 & 84 & 88 \\
32 & 87 & 86 \\
\hline
\end{tabular}

Fonte: Singh \& Viraraghavan (2003).

O trabalho mostrou que é possível a partida de reator UASB a baixas temperaturas para esgotos municipais em regiões frias (temperaturas médias no verão entre 15 e $20^{\circ} \mathrm{C}$ ). Reatores UASB podem ser projetados de forma otimizada para TDHs de 6 a 10 horas, para temperaturas acima de $11^{\circ} \mathrm{C}$. Comparado à qualidade típica requerida para o efluente de $30 \mathrm{mg} / \mathrm{L}$ de $\mathrm{DBO}$ e $\mathrm{SS}$, o reator do estudo conseguiu atender apenas ao limite de SS requerido. As altas concentrações de DBO no efluente (35 a $75 \mathrm{mg} / \mathrm{L}$ ) foram atribuídas à possível presença de produtos solúveis das bactérias que não podiam ser degradados em baixas temperaturas e baixos TDHs, portanto seria necessária a adição de um pós-tratamento para atender aos padrões de lançamento. 
Ekman et al. (2000) estudaram a partida do reator UASB (RALF) da cidade de Caxias do Sul - RS, com temperaturas médias de $16^{\circ} \mathrm{C}$, de janeiro de 1999 a julho de 2000. O sistema é constituído de gradeamento, duas unidades de desarenação, um UASB (com volume de $1000 \mathrm{~m}^{3}$ e formato tronco-cônico) e dois leitos de secagem. A partida ocorreu em 1998, quando então o reator recebia esgoto apenas 2 horas por dia. Em janeiro de 1999 iniciou-se o monitoramento e foram adicionadas cinco cargas (de 8 $\mathrm{m}^{3}$ cada uma) de lodo descartado da cidade de São Leopoldo (RS). Em março de 1999 iniciou-se o tratamento do esgoto, que chegava a ETE durante apenas 12 horas por dia. A partir de abril, passou-se a tratar todo o esgoto afluente durante 24 horas por dia. A vazão média atual é de $14 \mathrm{~L} / \mathrm{s}$, bastante inferior à de projeto $(46 \mathrm{~L} / \mathrm{s})$. O TDH do reator é de 36 horas. No primeiro ano de operação, a remoção de DBO e DQO sofreu grande redução na eficiência nos meses mais frios, ressaltando que o reator ainda não havia alcançado a estabilidade operacional. Nos últimos meses de 1999 o reator apresentou eficiências compatíveis com o esperado. No segundo ano de tratamento as variações não foram tão grandes e a eficiência de remoção foi consideravelmente maior que no mesmo período do ano anterior, principalmente nos meses mais frios, onde se manteve superior a $50 \%$, indicando possível estabilização do reator. A remoção de SS oscilou bastante, fator atribuído no primeiro ano às variações de carga hidráulica, além da infiltração de esgoto pluvial na rede coletora de esgoto. No segundo ano as oscilações foram menores, mas a eficiência situou-se abaixo de $50 \%$ para os meses de junho e julho, quando a temperatura afluente atingiu $14{ }^{\circ} \mathrm{C}$. A temperatura do afluente foi apontada como sendo um dos principais problemas na busca da eficiência desejada.

A comparação destes dois trabalhos ilustra que na transferência da tecnologia para a escala real, vários fatores interferem na obtenção das eficiências esperadas.

Speece \& Kem* (1970) apud Carrasco (1992), estudaram o efeito das variações de temperatura de curta duração na produção de metano, usando biodigestores mesofilicos $\left(35^{\circ} \mathrm{C}\right)$, alimentados com lodo bruto. Verificaram que a produção de metano foi particularmente sensível às variações de temperatura e parou quando a temperatura atingiu $20^{\circ} \mathrm{C}$. Quando a temperatura retornou a $35^{\circ} \mathrm{C}$ a produção de gás foi recuperada sem demora. Concluiu-se então que a resposta a mudanças bruscas de temperatura provoca a parada temporária da atividade, o que pode acarretar o colapso

\footnotetext{
* SPEECE, R.E., KEM, J.A. (1970). The effect of short temperature variations on methane production. Journal Water Pollution Control Federation. v. 42, n.11, pp. 1990-1997, nov.
} 
do processo se a taxa de carregamento for inicialmente elevada e não for diminuída ou interrompida, simultaneamente à mudança de temperatura.

Rowe $^{*}$ (1971) apud Carrasco (1992) estudou a digestão anaeróbia de esgoto doméstico nas faixas mesofílica e termofílica e determinou que quando a temperatura diminui a ação das bactérias também diminui. Atingindo a temperatura de $10{ }^{\circ} \mathrm{C}$, a atividade praticamente cessou. A concentração de nitrogênio amoniacal aumentou durante a digestão mesofílica, mas a digestão termofílica produziu ainda maior concentração de amônia. A alcalinidade foi a mesma para 35 e $55^{\circ} \mathrm{C}$, enquanto os ácidos voláteis no final do experimento apresentaram maiores concentrações a $35^{\circ} \mathrm{C}$ do que a $55{ }^{\circ} \mathrm{C}$. Houve, portanto, maior eficiência no digestor operado a $55^{\circ} \mathrm{C}$.

\subsubsection{Nutrientes}

Geralmente a relação DQO:N:P de 500:5:1 é suficiente para suprir as necessidades macro nutricionais (CHERNICHARO, 1997).

O nitrogênio orgânico presente no esgoto fresco está quase todo combinado sob forma de proteína, aminoácidos e uréia; as bactérias no seu trabalho de oxidação biológica transformam o nitrogênio presente primeiramente em amônia, depois em nitritos e finalmente em nitratos. A concentração com que o nitrogênio aparece sob estas várias formas indica a idade do esgoto ou a sua estabilização em relação à demanda de oxigênio. Os nitritos são muito instáveis no esgoto e se oxidam facilmente para a forma de nitratos. Sua concentração raramente excede $1,0 \mathrm{mg} / \mathrm{L}$ no esgoto (JORDÃO \& PESSÔA, 2005).

O fósforo existe na forma orgânica e inorgânica. O primeiro se encontra combinado à matéria orgânica, em proteínas e aminoácidos, e o segundo sob a forma de orto e polifosfatos.

O enxofre também é considerado nutriente essencial para a metanogênese em concentração normalmente igual ou levemente superior ao fósforo (FORESTI et al., 1999). Ele pode ser obtido de sulfetos e de proteínas.

Dentre os micronutrientes destacam-se Ferro, Cobalto, Níquel e Zinco (FORESTI et al., 1999).

\footnotetext{
* ROWE D.R. (1971). Anaerobic sludge digestion mesophilic-thermofilic. Water \& Sewage works. Chicago, v. 118, n.03, p. 74-76, mar.
} 
Os esgotos domésticos dificilmente apresentam deficiências nutricionais, sendo motivo de preocupação apenas no pós-tratamento, onde será necessário reduzir a concentração de macronutrientes (FORESTI et al., 1999).

\subsection{4 pH e alcalinidade}

O tratamento em reatores anaeróbios de alta taxa dificilmente irá requerer atenção especial à manutenção do $\mathrm{pH}$ na faixa entre 6,5 e 7,5 devido à predominância do sistema carbônico $\left(\mathrm{H}_{2} \mathrm{CO}_{3}, \mathrm{HCO}_{3}{ }^{-}, \mathrm{CO}_{3}{ }^{2-}\right)$. Valores baixos de $\mathrm{pH}$ poderão ocorrer quando da decomposição de compostos facilmente degradáveis como açúcares e amido na rede coletora, produzindo ácidos orgânicos (FORESTI, 1999), pois implicará em afluente à ETE já com altas concentrações de ácidos.

Nos casos em que ocorra queda do $\mathrm{pH}$, pode ser necessária a adição de alcalinidade, fator que pode afetar economicamente o tratamento anaeróbio em relação ao aeróbio.

É importante a distinção entre alcalinidade a bicarbonato e alcalinidade total (que inclui a alcalinidade a AGV). A alcalinidade a bicarbonato (parcial) é a total menos a alcalinidade equivalente a AGV (SPEECE, 1996). A alcalinidade parcial está relacionada à presença de íons bicarbonato, responsáveis pelo tamponamento do sistema no valor de $\mathrm{pH}$ desejado para as atividades biológicas; a alcalinidade total, por sua vez, inclui todos os compostos capazes de neutralizar ácidos.

\subsubsection{Sobrecargas hidráulicas}

Ainda há poucos dados referentes a sobrecargas hidráulicas na literatura, mas acredita-se que provoquem perda de sólidos orgânicos no efluente, que contribuem para aumento significativo da DQO efluente.

Chernicharo (1997) lembra que existe estreita relação entre a velocidade superficial de fluxo (ou velocidade ascensional), a altura do reator e o TDH. Para a vazão média a velocidade deve estar entre 0,5 e $0,7 \mathrm{~m} / \mathrm{h}$, para a vazão máxima entre 0,9 e $1,1 \mathrm{~m} / \mathrm{h}$ e para picos temporários de 2 a 4 horas as velocidades devem ficar abaixo de $1,5 \mathrm{~m} / \mathrm{h}$. 
Lettinga \& Hulshoff-Pol* (1991) apud METCALF \& EDDY (2003) citam que para esgotos domésticos a velocidade ascensional deve estar entre 0,8 e $1,0 \mathrm{~m} / \mathrm{h}$, com valores médios de $0,7 \mathrm{~m} / \mathrm{h}$. Para esgotos de baixa concentração a menor velocidade permitida e a altura do reator determinarão o volume do UASB. Para esgotos muito concentrados (“fortes") ele será determinado pela COV aplicada (METCALF \& EDDY, 2003).

Versiani et al. (2005) avaliaram os fatores associados ao desempenho de um reator UASB submetido a diferentes condições operacionais e aplicado ao tratamento de esgotos tipicamente domésticos. A unidade experimental de $22 \mathrm{~m}^{3}$ foi monitorada por 270 dias, divididos em 4 fases operacionais, segundo os seguintes tempos de detenção hidráulica: 9, 7, 5 e 3 horas, conforme descrito na Tabela 3.

Os resultados obtidos mostram que a fase III foi a que apresentou melhores resultados, exceto em relação à eficiência de remoção de SST, cuja maior eficiência ocorreu na fase IV. A velocidade ascensional apresentou-se como importante fator interveniente no desempenho do processo. Velocidades abaixo de 1,0 $\mathrm{m} / \mathrm{h}$ favoreceram o desempenho da unidade, provavelmente devido a uma maior adsorção e captura de sólidos afluentes na própria manta de lodo. Inversamente, a velocidade ascensional superior ao limite de $1,0 \mathrm{~m} / \mathrm{h}$ implicou na piora no desempenho da unidade, podendo ter acontecido um aumento na força hidráulica de cisalhamento, promovendo uma desagregação dos sólidos capturados.

Tabela 3 - Condições operacionais e eficiências médias de remoção em reator UASB.

\begin{tabular}{llllll}
\hline \multirow{2}{*}{ Parâmetros } & & \multicolumn{5}{l}{ Fases } \\
\cline { 3 - 6 } & & I & II & III & IV \\
\hline Vazão afluente & $\left(\mathrm{m}^{3} / \mathrm{h}\right)$ & 2,5 & 3,6 & 4,3 & 7,2 \\
& $\left(\mathrm{~m}^{3} / \mathrm{d}\right)$ & 60,5 & 86,4 & 103,7 & 172,8 \\
Tempo de detenção hidráulica & $(\mathrm{h})$ & 9 & 7 & 5 & 3 \\
Carga orgânica volumétrica & $\left(\mathrm{kgDQO} / \mathrm{m}^{3} \cdot \mathrm{d}\right)$ & 1,2 & 1,5 & 1,7 & 3,1 \\
Carga hidráulica volumétrica & $\left(\mathrm{m}^{3} / \mathrm{m}^{3} \cdot \mathrm{d}\right)$ & 2,8 & 3,9 & 4,7 & 7,9 \\
Velocidade ascensional afluente & $\left(\mathrm{m}^{3} / \mathrm{h}\right)$ & 0,6 & 0,8 & 1,0 & 1,6 \\
Eficiência de remoção & $(\%)$ & & & & \\
DQO & & 64 & 68 & 81 & 77 \\
\hline
\end{tabular}

* LETTINGA, G. HULSHOFF POL,L.W. (1991). UASB - process design for various types of wastewaters. Water Science and Technology, v. 24, n. 8, pp 87-107. 
Tabela 3 - Condições operacionais e eficiências médias de remoção em reator UASB.

\begin{tabular}{lllll}
\hline DBO & 71 & 75 & 80 & 68 \\
SST & 78 & 82 & 89 & 90 \\
\hline
\end{tabular}

Fonte: Versiani et al. (2005).

Oliva (1997) concluiu da operação de reator UASB de $18 \mathrm{~m}^{3}$ submetido a sobrecargas hidráulicas que as características da manta e leito de lodo (altura, densidade, etc.) eram diferentes a cada ensaio, evidenciando que as condições de sobrecarga hidráulica podem ser determinantes na ocorrência de curtos-circuitos nos reatores UASB. Esta autora também relata que a aplicação de vazões duas vezes maiores que a vazão normal de operação provoca aumento imediato de DQO efluente, até que o pulso seja interrompido.

A Tabela 4 resume as eficiências de remoção de DQO e SST, em porcentagem, para estudos em escala de bancada, piloto e real. Observa-se nesta tabela que três dos trabalhos em ETE real necessitavam operar em TDHs muito superiores aos de projeto, devido à baixa vazão afluente. Observa-se também que para escalas de bancada e piloto as eficiências médias de remoção de DQO e SST são respectivamente 70 e 80 \%; em escala real, diminuem para uma média de $60 \%$.

Tabela 4 - Eficiências de remoção de DQO em UASB.

\begin{tabular}{|c|c|c|c|c|}
\hline Referência & $\begin{array}{l}\text { TDH } \\
\text { (h) }\end{array}$ & $\begin{array}{l}\text { Efic. DQO } \\
(\%)\end{array}$ & $\begin{array}{l}\text { Efic. } \\
\text { SST(\%) }\end{array}$ & $\begin{array}{l}\text { Volume do } \\
\text { reator }\left(\mathrm{m}^{3}\right)\end{array}$ \\
\hline \multirow{4}{*}{ Versiani, 2005} & 9 & 64 & 78 & \multirow{4}{*}{22,0} \\
\hline & 7 & 68 & 82 & \\
\hline & 5 & 81 & 89 & \\
\hline & 3 & 77 & 90 & \\
\hline Carvalho et al., 2005 & 10 & 60 & variável & 0,16 \\
\hline \multirow{3}{*}{ Gonçalves et al., 1998} & 8 & 73 & 73 & \multirow{3}{*}{0,46} \\
\hline & 6 & 76 & 78 & \\
\hline & 4 & 68 & 74 & \\
\hline $\begin{array}{l}\text { Singh \& Viraraghavan, } \\
2003\end{array}$ & 6 e 4 & 84 & 90 & 1,0 \\
\hline $\begin{array}{l}\text { Silva \& Gonçalves, } \\
2005\end{array}$ & 7 & 62 & 72 & 28 \\
\hline Vieira et al., 2005 & 46 & $\begin{array}{l}65\left(\text { até a } 8^{a}\right. \\
\text { semana }-34)\end{array}$ & $\begin{array}{l}65 \text { (a partir } \\
\text { da } 15^{\mathrm{a}} \\
\text { semana) }\end{array}$ & $\begin{array}{l}\mathrm{Q}=25 \mathrm{~L} / \mathrm{s}^{(1)} / \\
\text { escala real }\end{array}$ \\
\hline Ekman et al., 2000 & 37 & 50 & $<50$ & $\begin{array}{l}1000 / \text { escala } \\
\text { real }\end{array}$ \\
\hline
\end{tabular}


Tabela 4 - Eficiências de remoção de DQO em UASB.

\begin{tabular}{|c|c|c|c|c|}
\hline \multirow[b]{2}{*}{$\begin{array}{l}\text { Gomes \& Chernicharo, } \\
2005\end{array}$} & (2) & 60 & $\begin{array}{l}\text { Muito } \\
\text { variável }\end{array}$ & $\begin{array}{l}\mathrm{Q}=40 \mathrm{~L} / \mathrm{s}^{(1)} / \text { escala } \\
\text { real }\end{array}$ \\
\hline & 8,4 & 60 & 59 & \multirow{5}{*}{$120 /$ escala real } \\
\hline \multirow{4}{*}{ Vieira, $1988^{(3)}$} & 9,0 & 70 & 70 & \\
\hline & 6,5 & 59 & 76 & \\
\hline & 7,4 & 59 & 56 & \\
\hline & 4,7 & 50 & 73 & \\
\hline
\end{tabular}

\subsubsection{Sobrecargas orgânicas}

O equilíbrio entre as colônias de microrganismos responsáveis pela digestão do efluente pode ser afetado por sobrecargas orgânicas durante o período de adaptação, levando a predominância da fermentação ácida sobre a metanogênica, prejudicando a remoção de matéria orgânica e sólidos suspensos.

Cargas orgânicas extremamente elevadas, da ordem de $45 \mathrm{kgDQO} / \mathrm{m}^{3} . \mathrm{d}$, têm sido aplicadas com sucesso em instalações piloto (CHERNICHARO, 1997). Para o caso de tratamento de esgotos de baixa concentração (esgotos domésticos), a carga orgânica não é o fator limitante, uma vez que a mesma é quase sempre inferior a 2,5 $3,0 \mathrm{kgDQO} / \mathrm{m}^{3} \cdot \mathrm{d}$.

\subsubsection{Crescimento bacteriano}

Outro fator importante na digestão anaeróbia é a atividade metanogênica. A concentração de biomassa no reator está ligada à concentração de sólidos voláteis em suspensão (SSV), portanto a atividade metanogênica do lodo pode ser obtida pela relação entre quantidade de DQO convertida em metano $\left(\mathrm{CH}_{4}\right)$, por unidade de tempo, e a concentração de SSV. O teste de atividade metanogênica específica (AME) baseia-se 
nestes fundamentos e tem sido utilizado no monitoramento do desempenho de reatores anaeróbios.

Existem apenas dois gêneros de arquéias metanogênicas capazes de metabolizar acetato: Methanosaeta e Methanosarcina. As Methanosarcina, além de utilizarem acetato, são capazes de utilizar também $\mathrm{H}_{2}, \mathrm{CO}_{2},\left(\mathrm{CH}_{3}\right)_{2} \mathrm{~S}$ e $\mathrm{CH}_{3} \mathrm{SH}$. Porém, a Methanosarcina utiliza preferencialmente os compostos de um carbono ao invés de acetato, enquanto a Methanosaeta somente é capaz de usar acetato. Espécies de Methanosaeta são predominantes em relação à Methanosarcina em (SMITH, 2006):

a) grânulos de digestores de lodo;

b) reatores que tratam ao mesmo tempo resíduos sólidos municipais e esgoto;

c) reatores UASB.

Durante a partida de reatores anaeróbios, espécies de Methanosarcina são freqüentemente predominantes graças às altas concentrações de acetato; entretanto, com a estabilização do bioreator e alcance da estabilidade operacional, há um decréscimo na concentração de acetato $\mathrm{e}$ as espécies de Methanosaeta substituem as de Methanosarcina. A Methanosaeta possui crescimento lento, de 2 a 12 dias de tempo de geração (SMITH, 2006).

\subsection{O reator UASB}

Possui várias denominações no Brasil (RAFA, DAFA, RAFAALL, RALF, entre outros), mas consagrou-se no mundo todo pela nomenclatura original inglesa dada por Lettinga: UASB - Upflow anaerobic sludge blanket. (FORESTI, 1999).

Não possui material de enchimento; a imobilização ocorre pela formação de flocos ou grânulos densos suspensos. Sua grande vantagem está na configuração que lhe permite o desenvolvimento de elevada quantidade de biomassa ativa (MacLeod et al., 1990) com elevado tempo de retenção celular, possibilitando a acomodação de altas cargas volumétricas, com curto TDH. Possui também adequada agitação e mistura hidráulica e conseqüente contato da biomassa com o substrato, promovidos pelo fluxo das bolhas de gás geradas na decomposição da matéria orgânica. Desempenha, portanto, função de decantador primário, reator biológico, decantador secundário e digestor de lodo.

O lodo do fundo do reator é bastante denso (4\% a $10 \%$, ou seja, em torno de 40000 a $100000 \mathrm{mgST} / \mathrm{L}$ ) e com excelentes características de sedimentação, podendo 
ocorrer grânulos de 1 a 5 mm de diâmetro, de acordo com a natureza do inóculo, das características do afluente e das condições operacionais do reator. É nesta zona que ocorre a maior parte da remoção do substrato (CHERNICHARO, 1997).

Ainda segundo Chernicharo (1997), acima do leito de lodo é formada a manta de lodo, onde o crescimento microbiano ocorre de forma mais dispersa, com menores velocidades de sedimentação. A concentração de lodo nessa zona varia normalmente de 1,5 a $3 \%$. O movimento ascensional das bolhas de biogás e do fluxo de esgoto é que promovem a mistura do sistema, por isso pode ser necessária uma forma adicional de mistura na partida (como recirculação do gás ou do efluente), visto que a produção de biogás é baixa.

A configuração de reator do tipo circular é adequada para atendimento de pequenas populações, usualmente com unidade única, por serem mais econômicos do ponto de vista estrutural. Para o atendimento de populações maiores, quando a modulação se torna necessária, os reatores retangulares passam a ser mais indicados, uma vez que uma parede pode servir a dois módulos contíguos (CHERNICHARO, 1997).

Reatores UASB têm como parâmetros de controle operacional o tempo de retenção de sólidos, o tempo de detenção hidráulica, as cargas volumétricas orgânicas e hidráulicas e a velocidade ascensional. A massa de sólidos na manta de lodo é parâmetro de controle do tempo de residência celular e serve para a caracterização da atividade metanogênica do processo anaeróbio. Para esgotos sanitários que não apresentam grandes variações em sua composição físico-química, variar o TDH representa variar inversamente as cargas volumétricas, orgânicas e hidráulicas aplicadas e a velocidade ascensional (VERSIANI et al., 2005).

Leitão et al. (2005) comentam que o comportamento hidrodinâmico da manta de lodo nos reatores UASB ainda não está esclarecido. Esta falta de informação faz com que o projeto e a operação destes reatores sejam realizados pelo método de tentativa e erro, principalmente no que diz respeito à altura apropriada da manta de lodo ou o espaço entre a manta e o separador de fases. O sistema de tratamento anaeróbio baseado em reator UASB tem sido bastante pesquisado no Brasil principalmente por ser um sistema bem adaptado às condições climáticas e operacionais disponíveis. Segundo Chernicharo (1997), o Brasil tem experiências bem sucedidas com estes reatores em diversas localidades do Paraná, São Paulo, Paraíba e Minas Gerais, sendo forte indicativo do potencial destes para o tratamento de esgotos domésticos. 
Além Sobrinho \& Jordão (2001) citam que no começo da década de 80 iniciaram-se os estudos no Brasil relacionados ao reator UASB. Sua simplicidade, altas taxas de tratamento, produção de lodo já estabilizado e custo atraente o fizeram merecedor da atenção de vários grupos de pesquisadores e engenheiros da área de tratamento de esgotos. Destacaram-se inicialmente a CETESB, a Escola de Engenharia de São Carlos da Universidade de São Paulo (EESC/USP), o Instituto de Pesquisas Tecnológicas de São Paulo (IPT) e especialmente a Companhia de Saneamento do Paraná - SANEPAR, que foi responsável pelo início e difusão da aplicação prática desses reatores anaeróbios.

Os mesmos autores ressaltam, contudo, que a exploração inadequada destes reatores para o tratamento de esgotos sanitários e despejos industriais, por alguns profissionais de conhecimento deficiente a respeito do sistema depurador, levou a resultados inferiores aos prometidos, desgastando a credibilidade destes reatores junto a vários órgãos estaduais e municipais de saneamento básico e a órgãos de controle de poluição das águas. Porém, a continuidade dos estudos e pesquisas com reatores UASB, bem como a seleção de melhores concepções destes reatores dentre as desenvolvidas pela equipe da SANEPAR (que os denomina RALF - reator anaeróbio de leito fluidizado), com elevado número de unidades implantadas no Paraná, na década de 90, e mais recentemente os trabalhos de pesquisa e divulgação da UFMG (Universidade Federal de Minas Gerais) e do grupo PROSAB (Programa de Pesquisa em Saneamento Básico), os reatores UASB vem retomando sua credibilidade, com a sua utilização em vários estados do país.

Estes reatores têm apresentado vantagens em relação aos sistemas convencionais aeróbios de tratamento de esgoto, como lodos ativados, pois substituem os decantadores primários e reduzem, aproximadamente, $70 \%$ da carga orgânica (em termos de DBO Demanda Bioquímica de Oxigênio) que segue para o pós-tratamento, diminuindo assim o consumo de oxigênio necessário para a estabilização da matéria orgânica.

Oliveira \& von Sperling (2005) avaliaram 166 ETEs em operação nos estados de Minas Gerais e São Paulo, entre janeiro de 1995 e agosto de 2003, compreendendo diversas tecnologias. Esses autores observaram grande variabilidade nas concentrações afluentes e efluentes, considerando todos os constituintes analisados e todas as modalidades de tratamento. Foram analisadas 30 ETEs com reatores UASB operando isoladamente que apresentaram desempenhos um pouco aquém do reportado pela literatura, considerando as concentrações de DQO, nutrientes e coliformes fecais (CF). 
A eficiência de remoção de DQO e DBO foi melhor, quando comparada aos dados da literatura do que os dados de SST e nutrientes, que apresentaram fraco desempenho. Os autores ressaltam que as condições de carga hidráulica e orgânica aplicada, do nível de operação, de aspectos hidráulicos e de fatores de projeto e de construção exercem uma grande influência no desempenho das ETEs, aspectos que não foram considerados no referido trabalho, que procurou apenas apresentar um diagnóstico da realidade do tratamento de esgotos no Brasil, considerando as principais tecnologias de tratamento, em termos da qualidade de seu efluente. Estes resultados retratam a realidade ora vivenciada, mas não o potencial de cada uma das tecnologias investigadas, que podem atingir desempenhos superiores aos apresentados.

Embora boa parte das unidades instaladas não seja seguida de pós-tratamento e também não atenda ao limite de DBO de $60 \mathrm{mg} / \mathrm{L}$ (CETESB - Companhia de Tecnologia de Saneamento Ambiental), alguns exemplos pioneiros encontram-se em funcionamento, como:

a) os filtros biológicos percoladores, já instalados nas três ETEs de Londrina $-\mathrm{PR}$

a) os sistemas de lodos ativados instalados na ETE Piracicamirim, de Piracicaba - SP;

a) os biofiltros aerados submersos instalados no Espírito Santo e em Minas Gerais (Além Sobrinho \& Jordão, 2001).

Além Sobrinho \& Jordão (2001) ressaltam ainda o tratamento físico-químico, com aplicação de cloreto férrico e polieletrólito e separação dos flocos por flotação com ar dissolvido, que já se encontram em operação em Campo Largo - PR e em Uberlândia - MG, além de sistema com separação de flocos por decantação com lamelas que se encontra em Cascavel - PR. Segundo estes autores, existe hoje uma grande tendência de utilização de reatores UASB seguidos de sistemas biológicos aeróbios para remoção de matéria orgânica (obtendo DBO efluente inferior a $30 \mathrm{mg} / \mathrm{L}$ ) e mesmo para a nitrificação do efluente final (obtendo nitrogênio amoniacal inferior a $5 \mathrm{mg} / \mathrm{L}$ ).

Jordão \& Pessoa (2005) relatam que no início o reator UASB era aplicado exclusivamente a esgotos com alta concentração de DQO ou DBO, como é o caso de despejos industriais específicos. Esgotos domésticos com baixa concentração de matéria orgânica só vieram a ter este processo aplicado com êxito a partir da metade dos anos 90. Comentam ainda que devido à sua operação extremamente simples e econômica este processo tem sido estudado e aprimorado principalmente em países em 
desenvolvimento, como Brasil, Colômbia, México e Índia, além da Holanda, onde surgiu.

Rennó \& d'Ávila (2005) comentam que tem sido expressivo o número de unidades de tratamento anaeróbio com reatores tipo UASB para efluentes domésticos projetadas e implementadas no estado de Minas Gerais nestes últimos anos. Após o início de operação de algumas dessas unidades, têm sido constatadas diferentes eficiências nos tratamentos e vários tipos de problemas operacionais, que se não identificados corretamente e solucionados tecnicamente poderão vir, no futuro, a comprometer a utilização efetiva desse tipo de tratamento, que tem a qualidade de seu efluente e os custos compatíveis com as necessidades de países como o Brasil.

\subsection{Produção e descarte de lodo}

Vieira* $^{*}$ (1988) apud Carrasco (1992) reportou os resultados do funcionamento de reator UASB em escala real $\left(120 \mathrm{~m}^{3}\right)$ para tratamento de águas residuárias domésticas, operado nas temperaturas de 21 a $25^{\circ} \mathrm{C}$ em diferentes TDHs $(8,4 ; 9,0 ; 6,5$; 7,4 e 4,7 horas). A produção de lodo foi aproximadamente de 45 a $60 \mathrm{kgSST} / 1000 \mathrm{~m}^{3}$ de esgoto tratado ou 0,15 a $0,20 \mathrm{kgSST} / \mathrm{kgDQOafl}$.

Gomes \& Chernicharo (2005), monitorando o sistema de tratamento de esgotos de Bonito - MS (composto de tratamento preliminar, UASB e infiltração no solo), relatam que apesar da aparente deficiência no protocolo de descarte do lodo do reator UASB, que possivelmente ocasionou maior perda de sólidos no efluente, o sistema apresentou desempenho considerado muito bom. O monitoramento foi de 15 meses, com vazão de alimentação intermitente de $23 \mathrm{~L} / \mathrm{s}$, com tempos médios de funcionamento da bomba elevatória de 11 a $13 \mathrm{~h} / \mathrm{d}$ (dias normais) e 16 a $18 \mathrm{~h} / \mathrm{d}$ (alta temporada). O descarte para o leito de secagem foi feito com intervalo de 90 dias.

De um modo geral, estes autores notaram um melhor desempenho do UASB nos seis primeiros meses de operação, quando as concentrações no efluente se mantiveram abaixo de $80 \mathrm{mg} / \mathrm{L}$ de DBO e $150 \mathrm{mg} / \mathrm{L}$ de DQO, e as eficiências usualmente entre 70 e $80 \%$ para DBO e 60 e $75 \%$ para DQO. Após este período inicial de excelente desempenho, observa-se que a DBO e DQO do efluente passaram a ser próximas a $100 \mathrm{mg} / \mathrm{L}$ e $200 \mathrm{mg} / \mathrm{L}$, respectivamente, com ciclos de melhoras que correspondem a

\footnotetext{
*VIEIRA, Sonia M.M. (1988). Anaerobic treatment of domestic sewage in Brasil - Research results and full-scale experience. In: PROCEEDINGS OF THE FIFTH INTERNATIONAL SYMPOSIUM ON ANAEROBIC DIGESTION, Bologña: Itália, pp. 185-196.
} 
aproximadamente 3 meses. Muito possivelmente, estes ciclos estão relacionados à rotina de descarte do lodo, feita em média a cada 3 meses. Após os descartes deve ocorrer diminuição da perda de sólidos suspensos no efluente, melhorando sua qualidade. Consideraram, portanto, este intervalo entre descartes como excessivo, por ter provocado aumento da perda de sólidos no efluente com picos de até $150 \mathrm{mgSST} / \mathrm{L}$.

A retenção de sólidos na manta de lodo é diretamente influenciada pela velocidade ascensional dos esgotos e pelas características de sedimentação dos flocos/grânulos de lodo. A velocidade ascensional pode, no entanto, apresentar dois efeitos opostos. Velocidades mais baixas promovem o aumento da colisão entre sólidos suspensos afluentes e a manta de lodo, permitindo a adsorção e a captura destes, além de facilitar a separação das bolhas de gases formadas na superfície da biomassa. Inversamente, velocidades mais elevadas tendem a aumentar a força hidráulica de cisalhamento, possibilitar a desagregação dos sólidos capturados e conseqüentemente reduzir a sua capacidade de sedimentação e de permanência na manta de lodo (MAHMOUND et al., 2003).

Versiani et al. (2005), relataram as variações na concentração de sólidos na manta de lodo mostradas na Tabela 5. Observou-se que embora elevadas concentrações de sólidos tenham sido alcançadas (superiores a 10 \%), em função da não realização de descarte de lodo ao longo da pesquisa, o desempenho do reator manteve-se satisfatório, apresentando pH médio igual a 7,0 e concentrações médias efluentes de $97 \mathrm{mg} / \mathrm{L}$ de DQO, $41 \mathrm{mg} / \mathrm{L}$ de DBO e $36 \mathrm{mg} / \mathrm{L}$ de SST, as quais mostraram-se adequadas ao padrão de lançamento de $60 \mathrm{mg} / \mathrm{L}$ de $\mathrm{DBO}$ e SST. No entanto, os autores recomendam a continuidade da investigação do reator UASB quando submetido a elevados acúmulos de sólido na manta de lodo, por se tratar de uma importante informação para a rotina operacional. O acúmulo de sólidos tende por um lado a comprometer a qualidade do efluente tratado; por outro, a sua retirada requer procedimentos de manejo, desidratação e destinação final do material.

Tabela 5 - Variação da concentração de sólidos na manta de lodo e massa de sólidos acumulada

\begin{tabular}{|c|c|c|c|c|c|c|}
\hline $\begin{array}{l}\text { Ponto de } \\
\text { amostragem }\end{array}$ & $\begin{array}{l}\text { Volume da } \\
\text { manta }\left(\mathrm{m}^{3}\right)\end{array}$ & $\begin{array}{l}\text { Altura do ponto } \\
\text { de amostragem } \\
\text { (m) }\end{array}$ & $\begin{array}{l}\text { ST } \\
\left(\mathrm{kg} / \mathrm{m}^{3}\right)\end{array}$ & $\begin{array}{l}\text { SVT } \\
\left(\mathrm{kg} / \mathrm{m}^{3}\right)\end{array}$ & $\begin{array}{l}\text { ST } \\
(\mathrm{kg})\end{array}$ & $\begin{array}{l}\text { SVT } \\
(\mathrm{kg})\end{array}$ \\
\hline P1 & 2,65 & 0,54 & $120-160$ & $78-100$ & 424 & 265 \\
\hline
\end{tabular}


Tabela 5 - Variação da concentração de sólidos na manta de lodo e massa de sólidos acumulada

\begin{tabular}{lllllll}
\hline P2 & 2,16 & 0,98 & $42-120$ & $29-66$ & 259 & 151 \\
P3 & 2,55 & 1,50 & $32-53$ & $19-28$ & 153 & 128 \\
Comp. de & 7,40 & - & $113(11,3$ & 74 & & \\
digestão & & & $\%)$ & $(7,4 \%)$ & 836 & 544 \\
\hline
\end{tabular}

Fonte: Versiani et al. (2005).

\subsection{Produção de biogás}

O gás gerado a partir da decomposição anaeróbia em meio líquido inclui os produtos típicos dessa atividade bacteriana: $\mathrm{CH}_{4}, \mathrm{CO}_{2}$ e $\mathrm{N}_{2}$. Além destes componentes estão presentes com menos freqüência e em pequena quantidade o $\mathrm{H}_{2}, \mathrm{H}_{2} \mathrm{~S}$ e $\mathrm{CO}$.

Singh \& Viraraghavan (2003) obtiveram aumento da produção de biogás com a diminuição do TDH e da temperatura. Este fato deveu-se ao aumento da taxa de carregamento orgânico ocorrida com a diminuição do TDH. A porcentagem de metano no total do biogás aumentou com a diminuição da temperatura e do TDH (para TDH superiores a 4 horas). Este fato pode ser atribuído ao aumento da solubilidade dos gases, que está associado com a diminuição da temperatura, assim como ao aumento dos diferentes graus destas solubilidades entre o metano, o dióxido de carbono e outros componentes do biogás. Devido ao aumento da solubilidade dos gases com a redução da temperatura, mais de $50 \%$ da produção estimada de metano pode ser perdida como metano dissolvido (pela lei de Henry).

Segundo Speece* (1983b) citado em Carrasco (1992), a produção de metano, a partir da remoção da matéria orgânica, expressa em termos de DQO, pode ser determinada conforme a relação estequiométrica expressa na eq.(1):

$$
\mathrm{CH}_{4}+2 \mathrm{O}_{2} \rightarrow \mathrm{CO}_{2}+2 \mathrm{H}_{2} \mathrm{O}+\text { energia }
$$

Assim, um mol, 22,4 litros em condições padrão de temperatura e pressão CNTP $(273,15 \mathrm{~K}$ e 101,325 kPa) - de metano é equivalente a 2 moles de oxigênio ou 64

\footnotetext{
* SPEECE, R.E. Review (1983b) - Environmental requirements for anaerobic digestion of biomass. In: ADVANCES IN SOLAR ENERGY: an anual review of research and development. Philadelphia: Environmental Studies Institute, Drexel University. 70 p.
} 
gramas de DQO. Por esta razão, a redução de 1 grama de DQO é equivalente à produção de 0,35 litros de metano.

Desta equivalência obtêm-se a correlação dada pela eq.(2).

$$
G=0,35 Q *\left(S_{0}-S\right)
$$

Onde:

$\mathrm{G}=$ taxa de produção de gás $\left(\mathrm{L}^{3} \mathrm{~T}^{-1}\right)$;

$\mathrm{Q}=$ volume de despejo por unidade de tempo $\left(\mathrm{L}^{3} \mathrm{~T}^{-1}\right)$;

$\mathrm{S}_{0}=$ concentração de substrato no afluente em massa/volume;

$\mathrm{S}=$ concentração de substrato no efluente em massa/volume.

O valor encontrado deve ser corrigido em função da temperatura e pressão

\subsection{Vedação do reator}

Rennó \& d'Ávila (2005), em estudo na ETE Bacia do Santana com quatro reatores de $2000 \mathrm{~m}^{3}$, recomendaram o uso de campânulas de fibra de vidro em reatores pela dificuldade de impermeabilização do concreto contra vazamento de gás. Estes autores relataram problemas operacionais com controle de odores, que deflagraram a necessidade de intervenção na unidade para a instalação de cobertura nos reatores para seu controle e minimização. Também comentam a necessidade de maior discussão quanto à especificação e instalação de medidores de gás.

\subsection{Retorno de lodo aeróbio ao reator UASB}

Cosentino et al. (2005) lembram que os custos envolvidos no tratamento e disposição final do lodo giram em torno de $50 \%$ dos custos operacionais das ETEs. Os lodos gerados em processos aeróbios precisam ser estabilizados antes da disposição final e a digestão anaeróbia é o processo mais antigo empregado para tal. A partir de 1996, sistemas anaeróbios-aeróbios, do tipo UASB + Lodos Ativados, vem sendo investigados para o tratamento de águas residuárias, visando manter a alta qualidade do efluente do reator de lodo ativado, mas reduzindo custos pelo pré-tratamento anaeróbio. Nesses sistemas, o UASB poderia também ser usado para estabilizar o lodo aeróbio produzido no reator aerado. Desta maneira, estes pesquisadores realizaram uma 
investigação experimental avaliando a viabilidade técnica de estabilização de lodo aeróbio em reatores UASB, tratando esgoto concomitantemente. Foram monitorados 4 reatores, alimentados com esgoto sanitário e com TDH de 6 horas. Os reatores 2, 3 e 4 receberam cargas adicionais de lodo de 20, 40 e $60 \%$ da carga orgânica de esgoto $\left(2,8 \mathrm{kgDQO} / \mathrm{m}^{3} \cdot \mathrm{d}\right)$. Os resultados mostraram que a estabilização do lodo aeróbio em reatores UASB era factível para a carga de $60 \%$. A estabilidade operacional em termos de $\mathrm{pH}$ e $\mathrm{AGV}$ não foi afetada. $\mathrm{O}$ desempenho quanto à remoção de $\mathrm{DQO}$ foi superior a $70 \%$ e o lodo estabilizado apresentou percentagens de SSV menores que $17 \%$.

Pontes et al. (2004) estudaram um sistema UASB + FBP (filtro biológico percolador) em escala piloto. Em seu estudo relataram que o retorno de lodo aeróbio pode provocar aumento no teor de polímeros extracelulares e diminuição no tamanho de partículas, nos pontos de maior altura do reator anaeróbio, prejudicando a sedimentabilidade do lodo.

Pontes \& Chernicharo (2005) avaliaram o efeito da recirculação ou não de lodo aeróbio sobre as características da biomassa em reator UASB. Concluíram que a estabilidade, a atividade metanogênica específica e a distribuição granulométrica do lodo não foram afetadas de maneira significativa pelo retorno de lodo aeróbio, embora o teor médio de proteínas e lipídeos extracelulares tenha apresentado diferença estatisticamente significativa da fase sem retorno de lodo para a fase com retorno de lodo.

Veronez (2001) avaliou o desempenho de um reator UASB no tratamento de esgoto sanitário bem como no adensamento e digestão de lodo de descarte de quatro biofiltros aerados submersos na ETE experimental da Universidade Federal do Espírito Santo, projetada para população de 1000 habitantes. O reator UASB se mostrou eficiente no tratamento de esgoto sanitário quando submetido a um TDH médio de 7 horas, produzindo um efluente com características médias de $52 \mathrm{mg} / \mathrm{L}$ (SST), $161 \mathrm{mg} / \mathrm{L}$ (DQO) e $95 \mathrm{mg} / \mathrm{l}$ (DQOfiltrada). As elevadas concentrações de ST (5 \%) e os teores de SV/ST (66 \%) encontrados no fundo do reator UASB indicam o bom funcionamento deste como unidade de adensamento e digestão de lodo aeróbio, descartando a necessidade de uma unidade de adensamento de lodos. Os resultados obtidos indicam que o reator UASB, além de possibilitar uma redução da matéria orgânica afluente aos biofiltros, preservando suas características básicas de eficiência e estabilidade no tratamento de esgoto, teve condições de receber o lodo aeróbio de 
descarte sem reflexo negativo no tratamento, sendo uma opção tecnológica viável e muito interessante dos pontos vista econômico e operacional.

Silva et al. (2005) deram continuidade ao estudo de Veronez (2001), avaliando através de AME o desempenho da biomassa de reator UASB que recebe continuamente lodo de lavagem de biofiltros. Os resultados mostraram que as concentrações de ST (\%) variaram claramente ao longo da altura do reator com valores de 5,2 \% de ST e 77,1 \% $\mathrm{SV} / \mathrm{ST}$, a $0,25 \mathrm{~m}$, caracterizando o lodo do fundo como bem adensado e relativamente bem digerido. A diminuição da concentração de sólidos com o aumento da altura indicou bom adensamento do lodo misto no reator UASB. Em relação à AME, os dados mostraram que o lodo coletado a $0,75 \mathrm{~m}$ do fundo do reator apresentou maior atividade e conseqüentemente maior taxa de produção de metano comparado ao lodo de 0,25 m. Conclui-se que a biomassa metanogênica acetoclástica ocorre em maior quantidade a $0,75 \mathrm{~m}$.

\subsection{Balanço de massa em reator UASB}

A realização de balanços de massa e energia em reatores UASB e em qualquer outro sistema de tratamento de águas residuárias é utilizada para definir, avaliar e otimizar o processo e o dimensionamento. Referente ao balanço de massas, o interesse de diferentes autores está na avaliação de resultados em termos de balanços de DQO, DBO e sólidos. A maior dificuldade na realização do balanço da DQO é quantificar o total de DQO que entra no reator, devido às variações de concentração no afluente (CARRASCO, 1992).

O balanço da DQO apresentado por Lettinga* (1989) apud Carrasco (1992), mostrado na Figura 1, foi obtido para temperaturas entre 8 e $20{ }^{\circ} \mathrm{C}$ a partir das eq. (3) e (4).

\footnotetext{
* LETTINGA, G. Anaerobic treatment of domestic sewage under dutch conditions - Notas de aula. Bogota- Universidade de Los Andes, 1989. 37 p.
} 


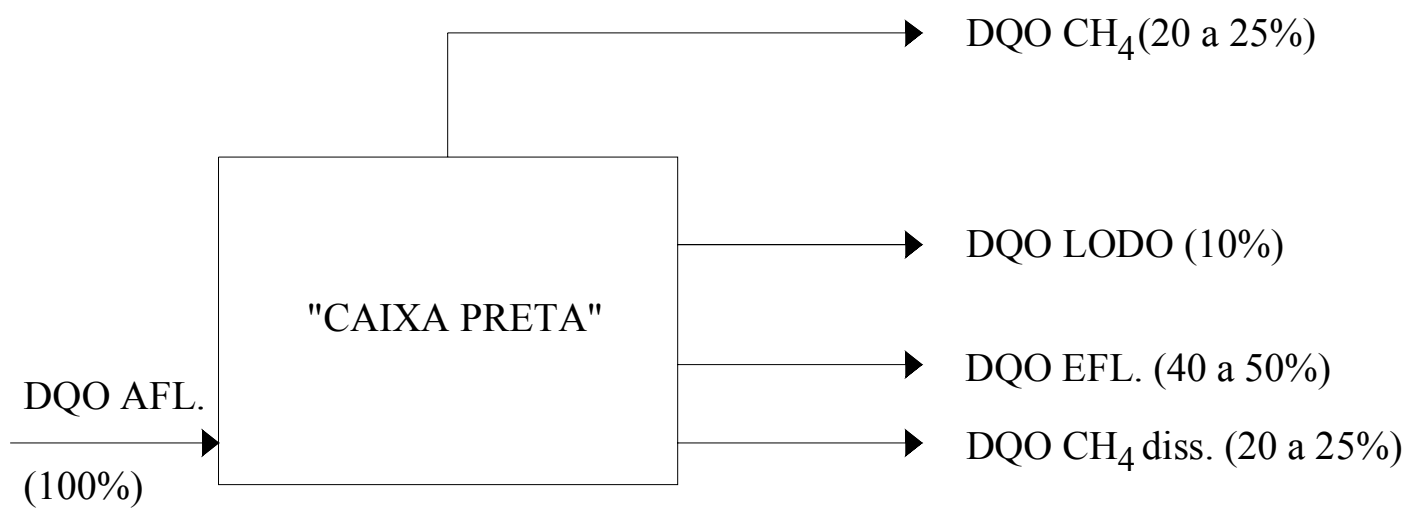

Figura 1 - Balanço da DQO (porcentagem representativa para reatores UASB com TDH de 8h). Fonte: Lettinga (1989) apud Carrasco (1992).

Balanço no reator:

Acumulação $=\mathrm{DQOa}-\mathrm{DQOe}-\mathrm{DQOlodo}-\mathrm{DQOCH}_{4}$ gás $-\mathrm{DQOCH}_{4}$ diss.

Em regime permanente:

Acumulação $=0$

- DQOa: Demanda química de oxigênio no afluente, em porcentagem;

- DQOe: Demanda química de oxigênio no efluente, em porcentagem;

- DQOlodo: Demanda química de oxigênio no lodo, em porcentagem;

- $\mathrm{DQOCH}_{4}$ : Demanda química de oxigênio que é convertida em metano, em porcentagem;

- DQOCH 4 diss: Demanda química de oxigênio que é convertida em metano, dissolvido no líquido, em porcentagem;

Esquemas similares ao da Figura 1 podem ser considerados para o balanço de DBO e sólidos. 


\subsection{Partida}

O inóculo a ser utilizado é de grande importância na partida do reator, pois resulta em maiores ou menores tempos de aclimatação de acordo com o grau de adaptação do lodo às características da água residuária a ser tratada.

Segundo Chernicharo \& Borges (1996), pode-se conseguir a partida de um reator anaeróbio de três maneiras: (1) com inóculo adaptado ao esgoto a ser tratado: partida rápida e satisfatória, pois dispensa a etapa de adaptação do lodo dentro do reator; (2) com inóculo não adaptado: necessário período de aclimatação, incluindo fase de seleção microbiana; (3) sem a utilização do lodo de inóculo: forma mais desfavorável. Como a concentração de microrganismos no esgoto é muito pequena, o tempo demandado para a retenção e seleção de elevada massa microbiana pode ser bastante prolongado.

De acordo com Chernicharo (1997), a partida de um UASB sem a utilização de inóculo pode demorar de 4 a 6 meses. Com a utilização deste em quantidade inferior a $4 \%$ do volume do reator se pode alcançar período de partida de 2 a 3 semanas.

Oliva (1997) operando reator UASB de $18 \mathrm{~m}^{3}$, com TDH de 16 horas e COV de $1,3 \mathrm{kgDQO} / \mathrm{m}^{3} . \mathrm{d}$, relatou período de duração da partida, sem inóculo, de cinco meses. A autora esperava período de tempo inferior a este e atribui o fato à variação qualitativa do afluente, que era proveniente da rede pública coletora da sub-bacia do córrego Tijuco Preto, que passa pelo Campus da EESC.

van Haandel \& Lettinga *(1994) apud Oliva (1997) definem a duração do período de partida como sendo o tempo necessário para obtenção de uma qualidade essencialmente constante do efluente e massa de lodo invariável com o tempo, em termos qualitativos e quantitativos. No entanto, Oliva (1997) ressalta que sob o ponto de vista prático parece bastante difícil atingir-se a situação de invariabilidade da massa de lodo e considerou em sua pesquisa o primeiro critério apresentado, ou seja, quando o efluente passou a apresentar características constantes.

Chernicharo \& Borges (1996) realizaram estudo com a partida de reator UASB, em escala real $\left(477 \mathrm{~m}^{3}\right)$, utilizando $16 \mathrm{~m}^{3}$ de lodo de digestor anaeróbio de ETE de cervejaria, com concentração de sólidos voláteis (SV) igual a $14 \mathrm{~g} / \mathrm{L}$. Utilizaram período

\footnotetext{
* van Haandel, A.C., LETTINGA, G. (1994). Tratamento aneróbio de esgotos - Manual para regiões de clima quente. Epgraf, Campina Grande, 210 p.
} 
de aclimatação de 24 horas sem alimentação, após a inoculação, monitorando pH, alcalinidade, DQO e ácidos voláteis do sobrenadante. Após duas semanas de operação, foi atingida a carga orgânica plena, correspondente a $1,25 \mathrm{kgDQO} / \mathrm{m}^{3}$.dia.

No caso do estudo citado, a quantidade de inóculo necessário seria de $141 \mathrm{~m}^{3}$, o equivalente a aproximadamente 20 caminhões-tanque. Como os possíveis locais de obtenção deste lodo situavam-se a mais de $100 \mathrm{~km}$ de distancia da ETE, optou-se por volume fixado em 20 ou $30 \mathrm{~m}^{3}$, variando-se a porcentagem da vazão total afluente a ser aplicada.

A inoculação pode ser feita com o reator cheio ou vazio, embora a segunda opção seja preferível, a fim de diminuir as perdas de lodo durante o processo de transferência. É então recomendado que o inóculo seja descarregado no fundo para evitar turbulências e contato excessivo com o ar; e que este lodo seja deixado em repouso pelo período aproximado de 12 a 24 horas, possibilitando a sua adaptação gradual à temperatura ambiente (CHERNICHARO \& BORGES, 1996).

\subsection{Alimentação do reator}

A taxa de alimentação do reator deve ser progressivamente aumentada segundo o sucesso de resposta do sistema, esperando-se após alguns meses de operação a formação de leito de lodo bastante concentrado (CHERNICHARO, 1997).

Chernicharo \& Borges (1996) recomendam para a alimentação do reator com esgotos, os seguintes passos:

a) Terminado o período de repouso, deve-se iniciar a alimentação do reator com esgotos até que o mesmo atinja aproximadamente a metade de seu volume útil;

b) Deve-se deixar o reator sem alimentação por período de 24 horas. Ao término deste período, e antes de iniciar a próxima alimentação, coletar amostras do sobrenadante do reator e efetuar análises dos seguintes parâmetros: temperatura, $\mathrm{pH}$, alcalinidade, ácidos voláteis e DQO. Caso estes parâmetros estejam dentro das faixas de valores aceitáveis, prosseguir o processo de alimentação. Valores aceitáveis: $\mathrm{pH}$ entre $6,8 \mathrm{e}$ 7,4 e ácidos voláteis abaixo de $200 \mathrm{mg} / \mathrm{L}$ (como ácido acético);

c) Prossegue-se com o enchimento do reator, até que o mesmo atinja o seu volume total (nível dos vertedores do decantador); 
d) Deixar novamente sem alimentação por outro período de 24 horas. Ao término deste período retirar novas amostras para serem analisadas e proceder como anteriormente;

e) Caso os parâmetros analisados estejam dentro das faixas estabelecidas, iniciar a alimentação contínua do reator (50 a 60 \% da vazão total afluente);

f) Implantar e proceder monitoramento de rotina do processo de tratamento; e

g) Proceder aumento gradual da vazão afluente, inicialmente a cada 15 dias, de acordo com a resposta do sistema. Este intervalo poderá ser ampliado ou reduzido, dependendo dos resultados obtidos.

\subsection{Granulação}

De acordo com Vallejos (1997), uma das principais características da digestão anaeróbia em reator UASB é a formação de lodo com alta atividade específica e boas propriedades de sedimentação. Este lodo é obtido lentamente ao longo de meses, propiciando a formação do lodo granular.

Segundo MacLeod et al. (1990), a associação das bactérias acidogênicas e acetogênicas com arquéias metanogênicas em estruturas granulares garante alto nível de atividade metabólica, permitindo o estabelecimento de associações celulares obrigatórias para a utilização de determinados substratos, como a degradação do propionato e do butirato, que são termodinamicamente desfavoráveis a menos que as bactérias hidrogenotróficas removam o $\mathrm{H}_{2}$ do meio. Estas associações são encontradas em mini-agregados observados na fase líquida de co-culturas de oxidadores de butirato e consumidores de $\mathrm{H}_{2}$, não sendo, portanto, surpresa encontrar esta justaposição de degradadores de propionato e consumidores de $\mathrm{H}_{2}$ ocorrendo nos grânulos de reatores UASB.

Estes autores submeteram grânulos de lodo formados em reator UASB à microscopia eletrônica de varredura $(\mathrm{MEV})$, onde foram encontradas populações microbianas dispostas em três camadas, de morfologias distintas. Foram usados no estudo reatores de $13,5 \mathrm{~L}$, a $35^{\circ} \mathrm{C}$, inoculados com lodo granular de reator UASB que tratava efluente de fábrica de queijo, alimentados com meio de sacarose, à velocidade ascensional de $0,9 \mathrm{~m} / \mathrm{h}$, taxa de carregamento orgânico de 1,3 gDQO/gSSV.dia. A camada exterior continha bactérias acidogênicas; a camada intermediária continha bactérias acetogênicas e hidrogenotróficas. No núcleo do grânulo, observou-se a presença de Methanosaeta, sugerindo que estes organismos iniciam o desenvolvimento 
granular. Possivelmente, os emaranhados de filamentos de Methanosaeta funcionaram como uma estrutura suporte que pôde ser colonizada por uma sucessão de outros organismos, por exemplo, os produtores de acetato (provendo substrato para as metanogênicas), além de associações sintróficas com as bactérias consumidoras de hidrogênio, baixando a concentração de hidrogênio no meio. Esta relação sintrófica é importante para que o $\mathrm{pH}$ do meio não decresça pela alta concentração de hidrogênio. A adesão das bactérias fermentativas ao mini-agregado, formando a camada exterior do grânulo, promoveria o contato entre este grupo metabólico e o substrato presente no meio.

Singh \& Viraraghavan (2003), em estudo em escala de laboratório utilizando esgoto sanitário com concentrações de 350-600 mg/L (DQO), 150-200 mg/L (DBO e SS) e $50-100 \mathrm{mg} / \mathrm{L}$ de sulfato, caracterizado como efluente de concentrações médias (METCALF \& EDDY, 2003), observaram a formação de grânulos a $20{ }^{\circ} \mathrm{C} . \mathrm{Na}$ visualização em MEV foram encontrados agregados de biomassa de formato irregular com superfície áspera, com predominância de filamentos de Methanosaeta sp na superfície. Quantidades significativas de substâncias poliméricas estavam presentes. Possivelmente foram excretadas pelos microrganismos e provavelmente atuaram como material adesivo para formar os agregados de biomassa ou ajudar a agrupar células na superfície inerte. A rugosidade da superfície também influenciou o agrupamento das células microbianas, proporcionando proteção para as partículas menores da ação da força de cisalhamento e aumentando a superfície disponível para uniões. Não foram observadas diferenças significativas na composição bacteriológica do agregado de biomassa com a diminuição da temperatura. $\mathrm{O}$ tamanho médio dos grânulos foi de $1,8 \mathrm{a}$ $3,0 \mathrm{~mm}$ à temperatura de $11^{\circ} \mathrm{C}$. Esse tamanho foi ligeiramente maior comparado com o tamanho a $20^{\circ} \mathrm{C}(1,5$ a 2,5 mm). A análise da composição da superfície dos grânulos, por difração de raios-X, indicou que cátions bivalentes como os de cálcio e magnésio facilitaram a adesão das células. A porcentagem atômica dos íons de sódio na superfície aumentou com o decréscimo da temperatura de operação, o que possivelmente resultou num tipo mais frágil de matriz de biomassa agregada à temperatura de $11{ }^{\circ} \mathrm{C}$, quando comparado a 20 e $32^{\circ} \mathrm{C}$.

Vieira et al. (2005) obtiveram na $19^{\mathrm{a}}$ semana após a partida de reator UASB da ETE Lages a formação de lodo a $0,50 \mathrm{~m}$ de profundidade com característica granular e bastante homogênea. O esgoto afluente tinha valores médios de DQO de $400 \mathrm{mg} / \mathrm{L}$, DBO de $130 \mathrm{mg} / \mathrm{L}$, ST de $580 \mathrm{mg} / \mathrm{L}$ e SST de $200 \mathrm{mg} / \mathrm{L}$, sendo classificado como 
esgoto de características médias de acordo com Metcalf \& Eddy (2003). Vale ressaltar que o TDH deste reator foi de 46 horas, devido à baixa vazão afluente, o que pode justificar o fato de não ter sido reportada granulação nos demais trabalhos, em estações reais em início de operação, consultados para a revisão bibliográfica desta dissertação, para tratamento de esgotos domésticos em UASB.

Vieira $^{*}$ (1988) apud Carrasco (1992) em sua pesquisa com UASB em escala real, obteve lodo inteiramente floculento, que não formou grânulos. As concentrações afluentes eram de $300 \mathrm{mg} / \mathrm{L}$ (DQO), $140 \mathrm{mg} / \mathrm{L}$ (DBO) e $150 \mathrm{mg} / \mathrm{L}$ (SST), caracterizando um efluente de baixa concentração (METCALF \& EDDY, 2003).

\subsection{Disposição de lodo de fossas sépticas em estações de tratamento de}

esgoto.

A ausência, total ou parcial, de serviços públicos de esgotos sanitários nas áreas urbanas, suburbanas e rurais exige a implantação de algum meio de disposição dos esgotos locais com o objetivo principal de evitar a contaminação do solo e da água. A lentidão na implantação de serviços, em relação ao crescimento populacional, principalmente nos países em desenvolvimento, permite prever que soluções individuais para o destino de esgotos continuarão a ser permanentemente adotadas. Dentre estas, as fossas sépticas, processo patenteado há quase um século, que perdurará por outro tanto como solução econômica para residências isoladas (JORDÃO \& PESSÔA, 2005).

O efluente das fossas sépticas poderá apresentar, periodicamente, grande quantidade de sólidos. Esta condição é geralmente causada pela grande atividade bacteriana do líquido retido, a qual é responsável pela formação de gases e turbulência (JORDÃO \& PESSÔA, 2005).

A adoção da disposição do lodo de fossas sépticas em ETEs exige que as instalações existentes disponham de capacidade disponível para receber a carga sólida (lodo) nas unidades de tratamento de lodo e estejam localizadas a distâncias que tornem economicamente viável o transporte desse lodo.

Em geral, requer-se que a ETE disponha de um tanque de recebimento e acumulação do lodo de fossas, de modo que o material acumulado possa ser bombeado

\footnotetext{
*VIEIRA, S.M.M. (1988). Anaerobic treatment of domestic wastewater in Brazil: research and full scale experience. Advanced Water Pollution Control, n. 5, pp. 185-196.
} 
em quantidades controladas para as unidades de tratamento. É importante lembrar que o lodo de fossas sépticas possui razoável quantidade de escuma. A análise da Tabela 6 mostra a dimensão dos impactos que podem ser gerados, com os importantes acréscimos de DBO e SST, devendo, portanto, a ETE estar preparada para receber estas contribuições.

Vieira et al. (2005) relataram que na ETE Lages, com o lançamento de lodo de limpa-fossas, no período em que recebia aproximadamente 10 caminhões diários, $29^{\mathrm{a}}$ semana de operação, o reator UASB apresentou eficiência negativa, indicando um acréscimo de matéria orgânica no efluente.

Tabela 6 - Características dos lodos de fossas sépticas.

\begin{tabular}{lll}
\hline Parâmetro & Faixa típica & Concentração típica (mg/L) \\
\hline DBO & 2000 a 30000 & 6000 \\
SST & 2000 a 100000 & 15000 \\
SSV & 1200 a 14000 & 7000 \\
NTK & 100 a 1600 & 700 \\
N amoniacal & 100 a 800 & 400 \\
P & 50 a 800 & 250 \\
OG & 500 a 10000 & 8000 \\
\hline
\end{tabular}

Fonte: Jordão \& Pessôa (2005). 
4 INSTALAÇÕES DO EXPERIMENTO

Na Figura 2 encontra-se um fluxograma do processo de tratamento na ETE Água Vermelha.

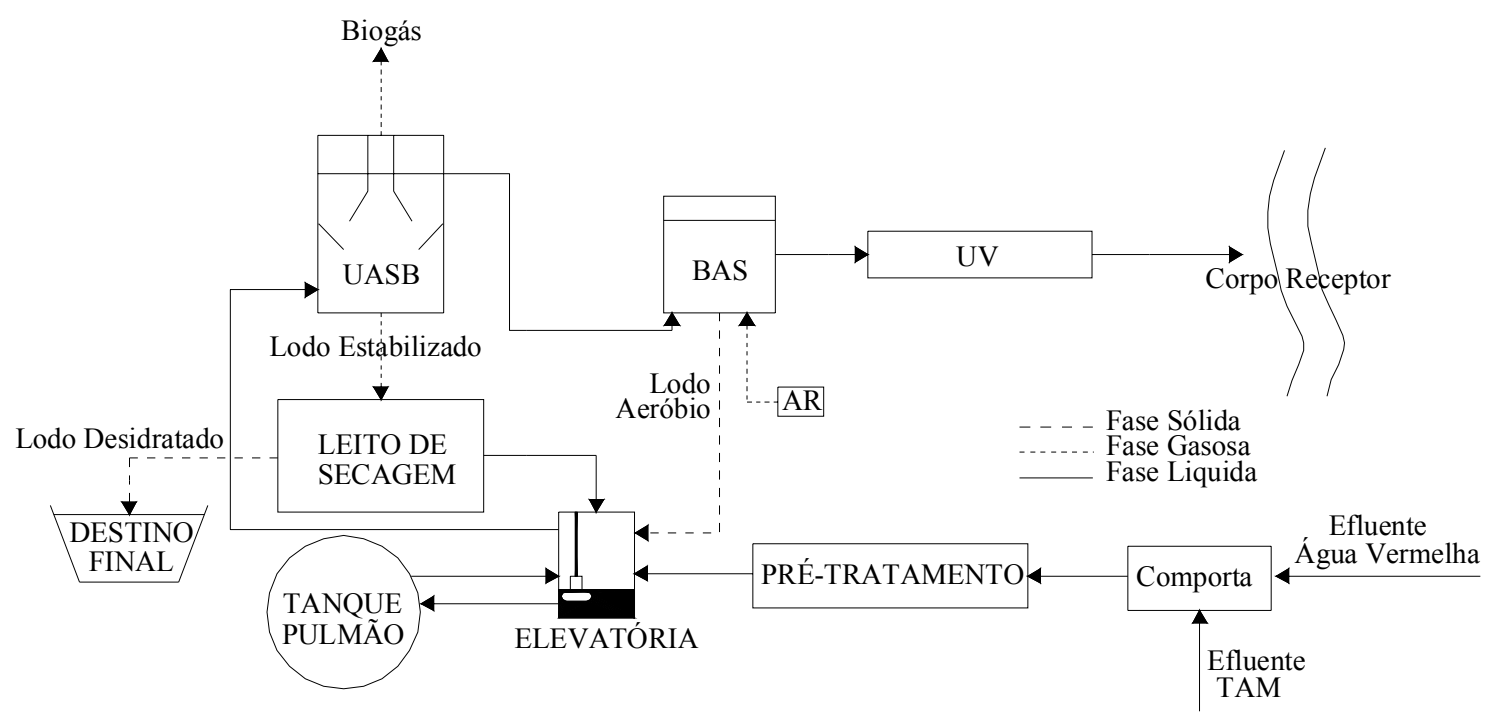

Figura 2 - Fluxograma de tratamento.

A Figura 3 mostra o tratamento preliminar da ETE Água Vermelha. 


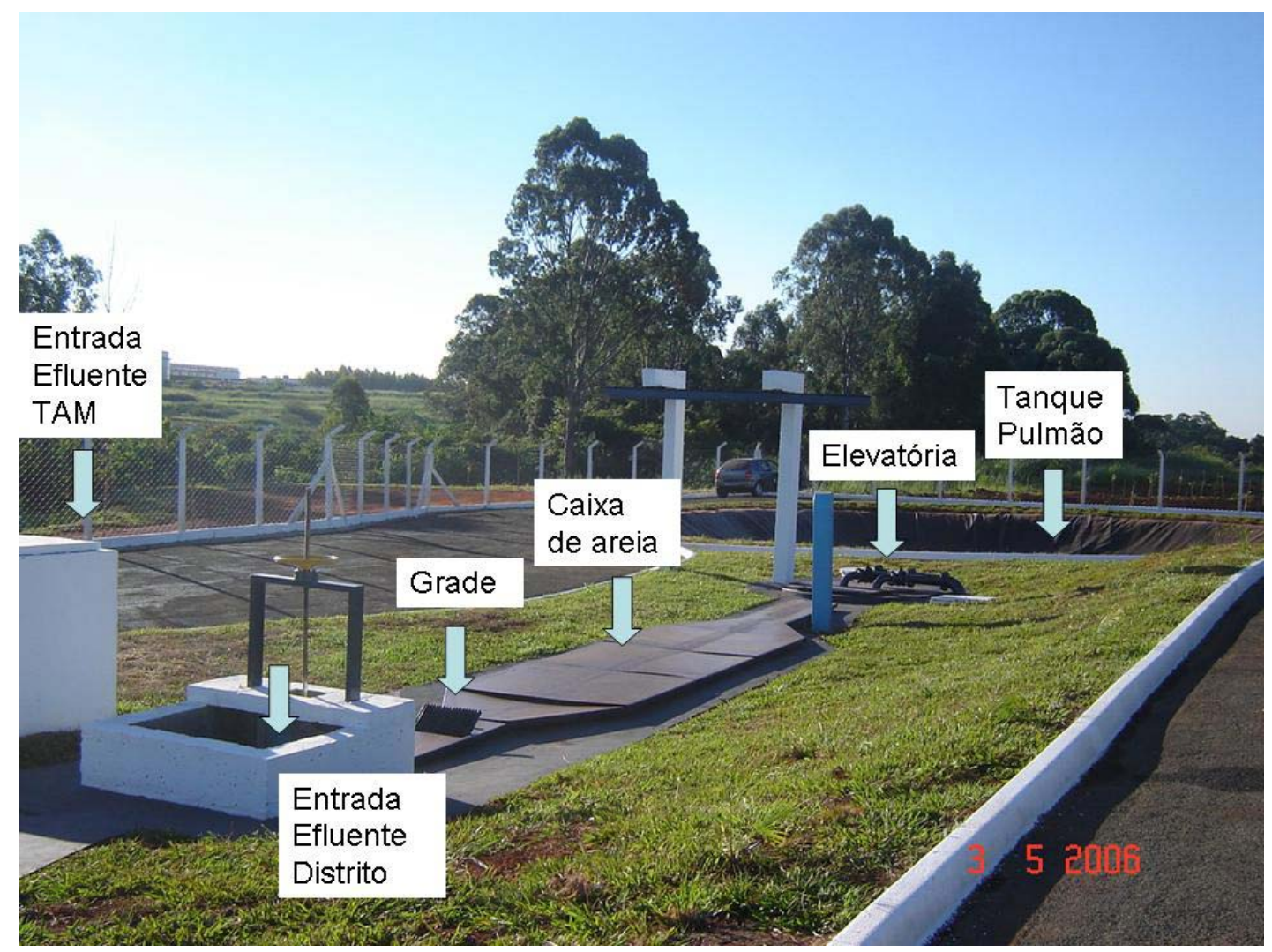

Figura 3 - Tratamento preliminar da ETE Água Vermelha.

\section{- Grade fina de limpeza manual}

Com a função de reter sólidos grosseiros, é constituída de 19 barras metálicas, com seção retangular de 1/4" x 1 1/2" (6 mm x $40 \mathrm{~mm}$ ), com espaçamento entre elas de $1,9 \mathrm{~cm}$. Possui $50 \mathrm{~cm}$ de largura, com fundo e paredes em aço, revestido de fibra de vidro. A Figura 4 mostra em detalhe a grade fina de limpeza manual.

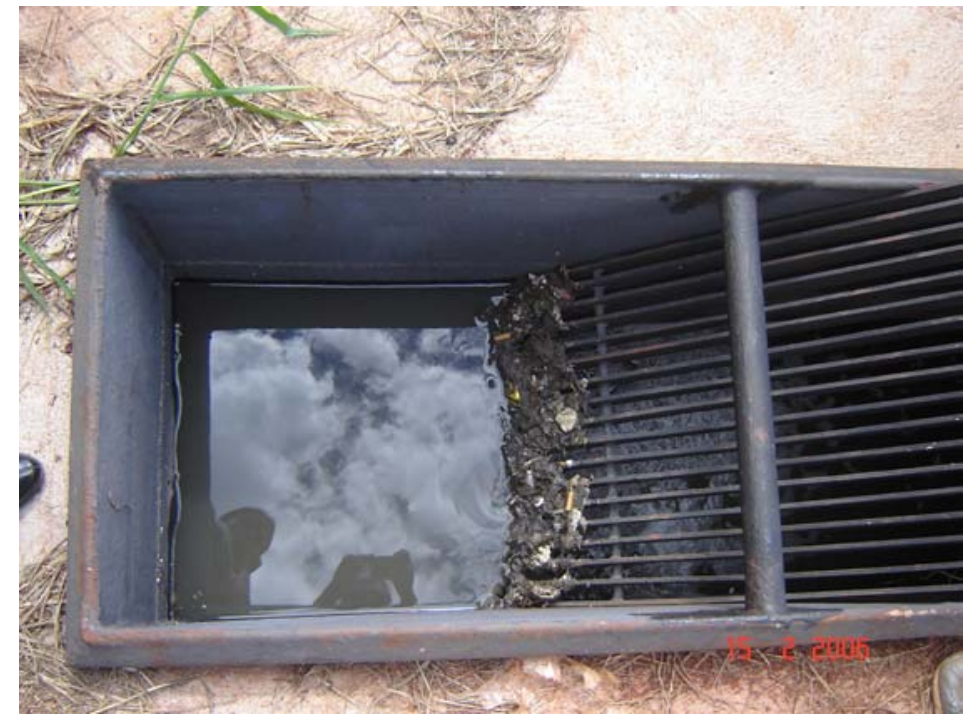

Figura 4 - Detalhe da grade fina de limpeza manual. 


\section{- Caixa de areia prismática retangular por gravidade}

Foi dimensionada para remover no mínimo $95 \%$ de partículas com diâmetros maiores ou iguais a $0,2 \mathrm{~mm}$. É formada por duas câmaras de operação independente, de seção transversal retangular, com 0,40 m de largura e 3,90 m de comprimento, também constituídas de estrutura metálica revestida por vibra de vidro. A Figura 5 mostra em detalhe a caixa de areia e o medidor de vazão tipo Parshall.

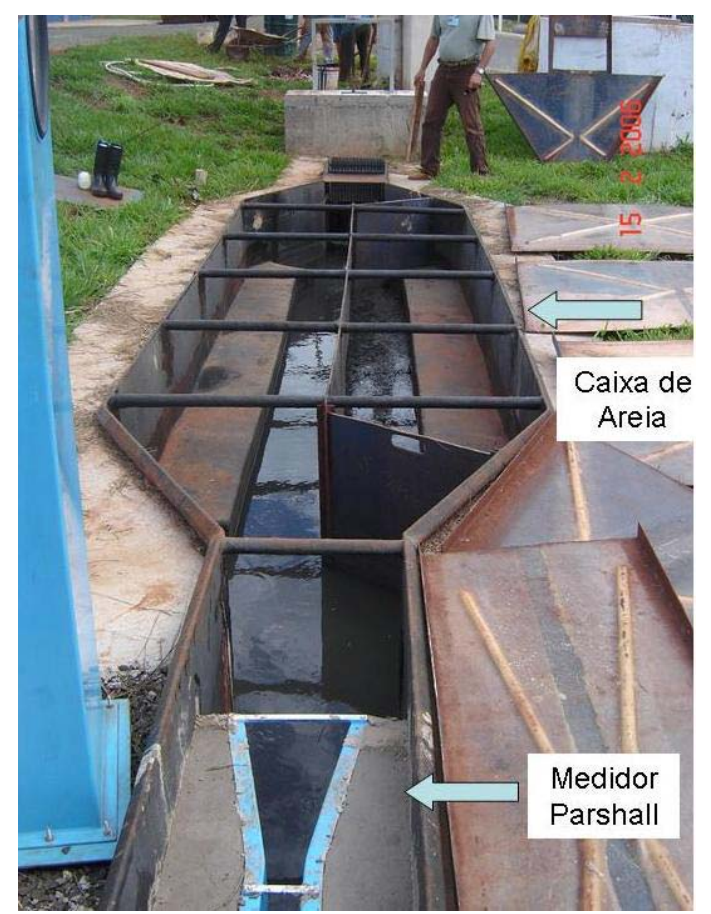

Figura 5 - Detalhe da caixa de areia e o medidor de vazão tipo Parshall.

\section{- Medidor de vazão tipo Parshall}

Com medida de garganta de 3" (7,6 cm), é utilizada na medição da vazão afluente à ETE.

\section{- Poço pulmão}

Antiga lagoa anaeróbia da ETE antes de efetuada a reforma que foi mantida no projeto atual para funcionar como poço pulmão, armazenando esgotos gradeados e desarenados em caso de falta de energia elétrica; 


\section{- Estação elevatória de esgotos}

Após gradeado e desarenado, o esgoto segue para a estação elevatória, sendo então bombeado para o reator UASB. O lodo de lavagem do BAS é também destinado à estação elevatória para ser posteriormente tratado no UASB, juntamente com o esgoto pré-tratado.

\section{- Reator Anaeróbio de Manta de Lodo (UASB)}

Responsável pelo tratamento primário, com remoção média de matéria orgânica $\left(\mathrm{DBO}_{5}\right)$ de projeto da ordem de $70 \%$.

A Figura 6 mostra os reatores UASB e BAS e as válvulas de lavagem que encaminham o lodo aeróbio à estação elevatória para em seguida retornar ao UASB.

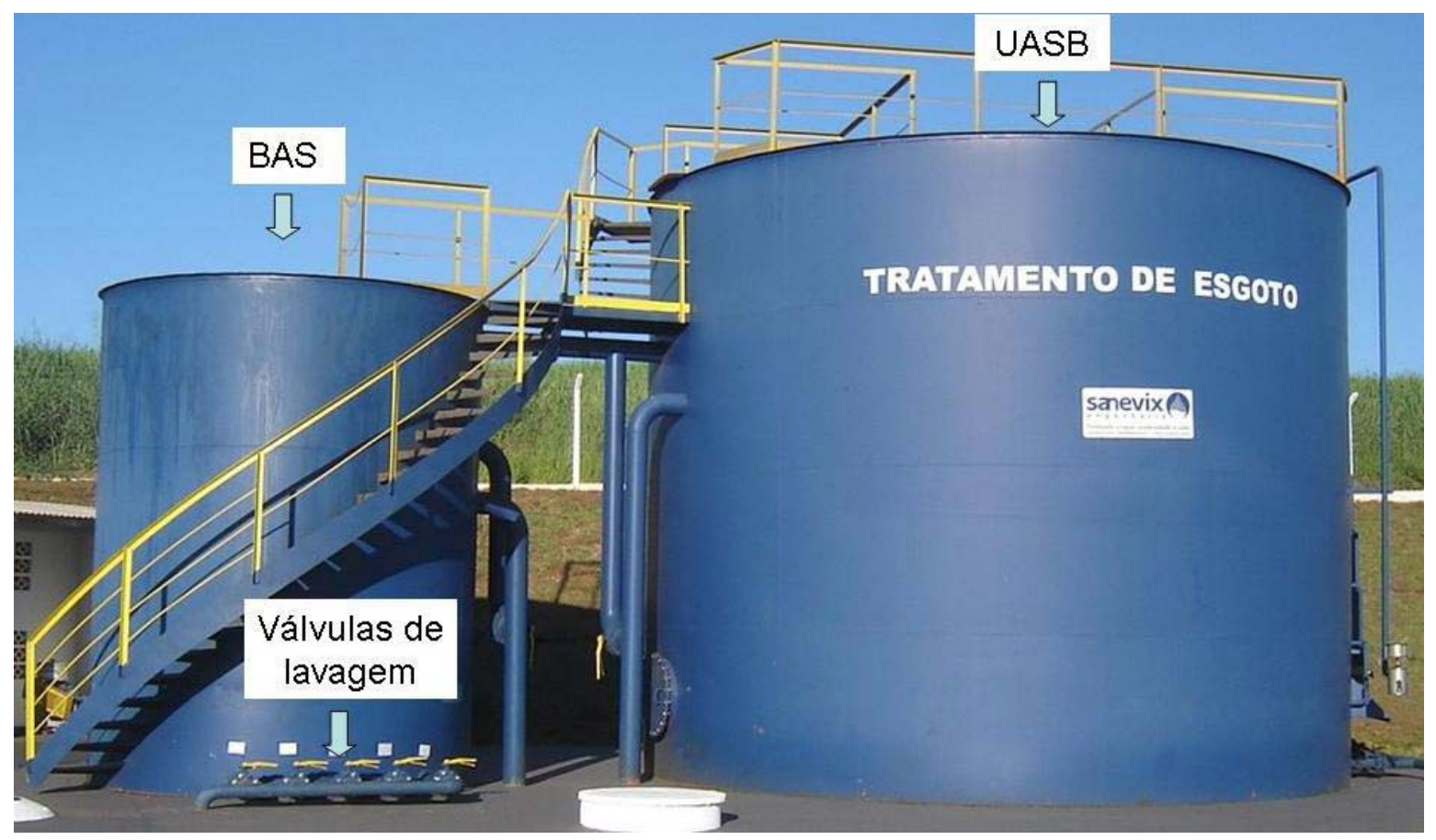

Figura 6 - Reatores UASB e BAS e as válvulas de lavagem.

\section{- Biofiltro Aerado Submerso (BAS)}

Responsável pelo polimento do efluente do UASB, através da remoção de compostos orgânicos e nitrogenados, com eficiência de remoção de $\mathrm{DBO}_{5}$ de projeto superior a $95 \%$. Possui soprador, dotado de silenciador, com vazão de ar variando de $86,3 \mathrm{~m}^{3} / \mathrm{h}$ até $198,3 \mathrm{~m}^{3} / \mathrm{h}$ e pressão de $34,5 \mathrm{kPa}$. A distribuição de ar no fundo é feita por dispositivos com membrana de bolha grossa. 


\section{- Dispositivo de desinfecção dos esgotos por ultravioleta}

Dispositivo para redução de coliformes atendendo o padrão de lançamento para Classe 2 (valores abaixo de $1000 \mathrm{NMP} / 100 \mathrm{ml}$ ). Possui 150 lâmpadas de baixa pressão de vapor de mercúrio, com potência nominal de $30 \mathrm{~W}$ cada uma. As lâmpadas germicidas são fixadas em refletores de alumínio polido, construídos em chapa de $3 \mathrm{~mm}$ de espessura. A Figura 7 mostra a vista geral da câmara de desinfecção por UV.

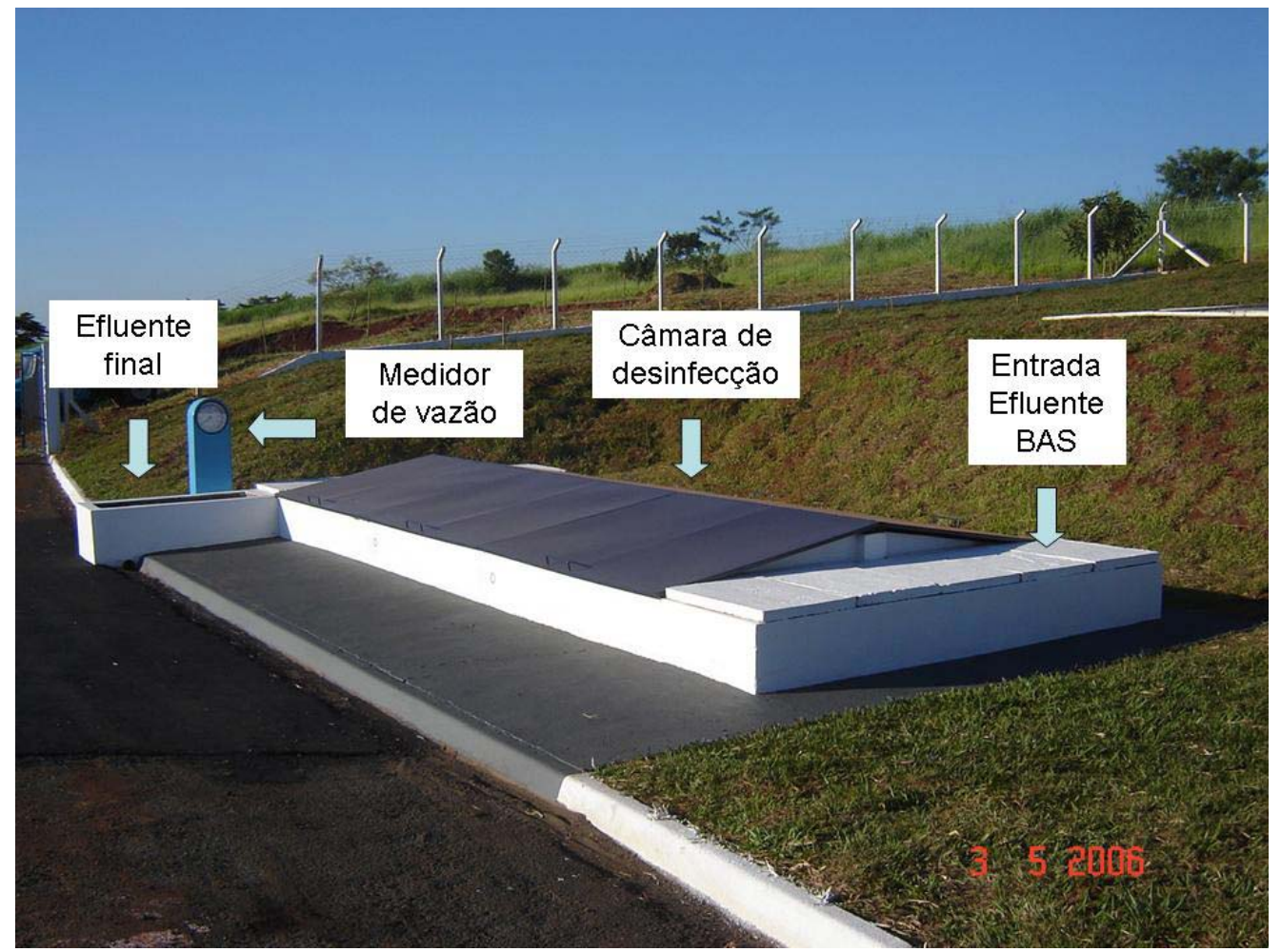

Figura 7 - Vista geral da câmara de desinfecção por UV.

\section{- Leito de Secagem}

Para desidratação por processo natural do lodo proveniente do UASB, esta unidade possui dois leitos, tendo cada um dimensões internas de 6,00 m x 9,00 m, totalizando $108 \mathrm{~m}^{2}$. A Figura 8 mostra os leitos de secagem. O leito da esquerda encontra-se em uso e no da direita pode-se observar a camada superior de tijolo maciço comum. As camadas inferiores são de $0,10 \mathrm{~m}$ de areia grossa, $0,15 \mathrm{~m}$ de brita $\mathrm{n}^{\mathrm{o}} 1$, $0,25 \mathrm{~m}$ de brita $\mathrm{n}^{\mathrm{o}} 3$ e $0,13 \mathrm{~m}$ de brita $\mathrm{n}^{\mathrm{o}} 4$. Após percorrer estas camadas a fração líquida do lodo é conduzida através de tubo de PVC corrugado e perfurado, de DN 100 $\mathrm{mm}$, para caixas coletoras que o encaminham de volta à estação elevatória. 


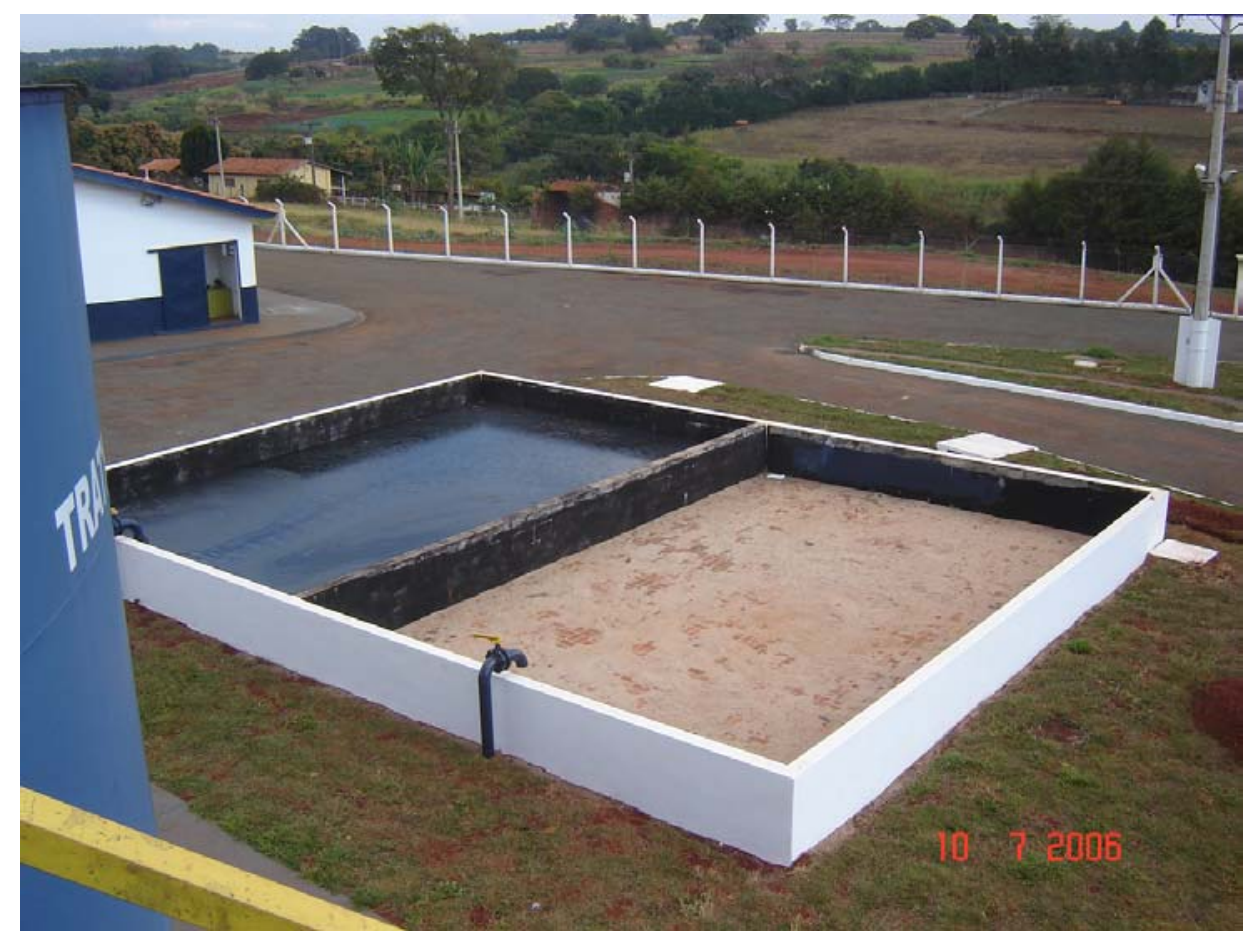

Figura 8 - Leitos de secagem.

\section{- Escada Hidráulica}

Tem a função de adequação da velocidade de lançamento do efluente no ribeirão Araras. Construída em concreto, com dimensões internas de 0,50 m de largura e degraus com espelho de $0,30 \mathrm{~m}$ e comprimento de $0,50 \mathrm{~m}$.

O reator UASB utilizado na pesquisa (Figura 9) tem 7,38 $\mathrm{m}$ de diâmetro, 6,06 m de altura útil e $235 \mathrm{~m}^{3}$ de volume útil. O reator possui um dispositivo de distribuição do afluente, com o objetivo de distribuir a vazão tão uniformemente quanto possível sobre o fundo do reator, promovendo o contato com o lodo presente. A entrada deste dispositivo localiza-se em cota mais elevada que o nível de água (N.A.) no UASB, possibilitando que a alimentação seja feita por gravidade.

A Figura 10 mostra a chegada da tubulação de recalque que traz o esgoto da estação elevatória até a caixa distribuidora de vazão no topo do UASB. 


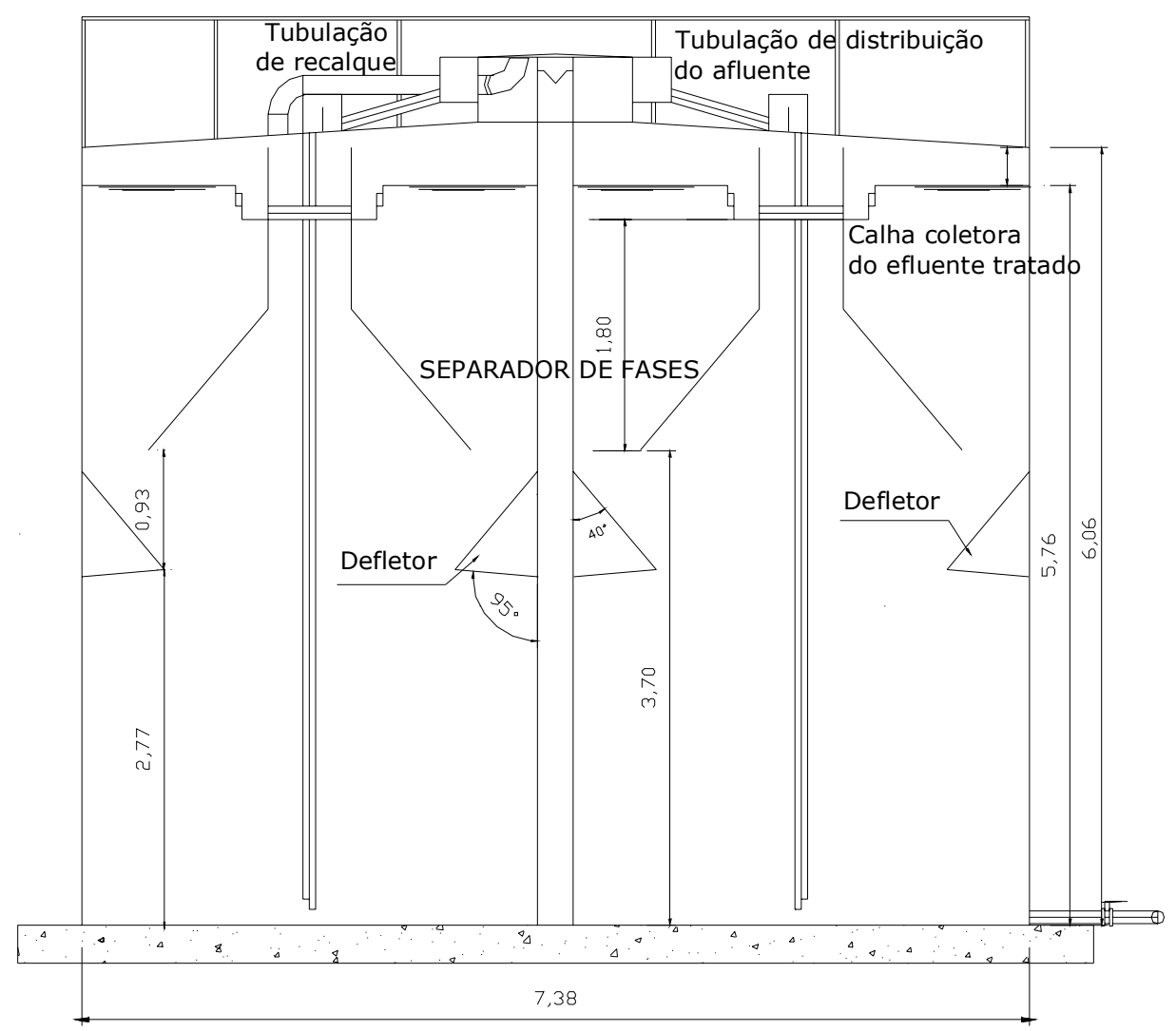

Figura 9 - Corte esquemático do reator UASB - Fonte: Kellner (2003).

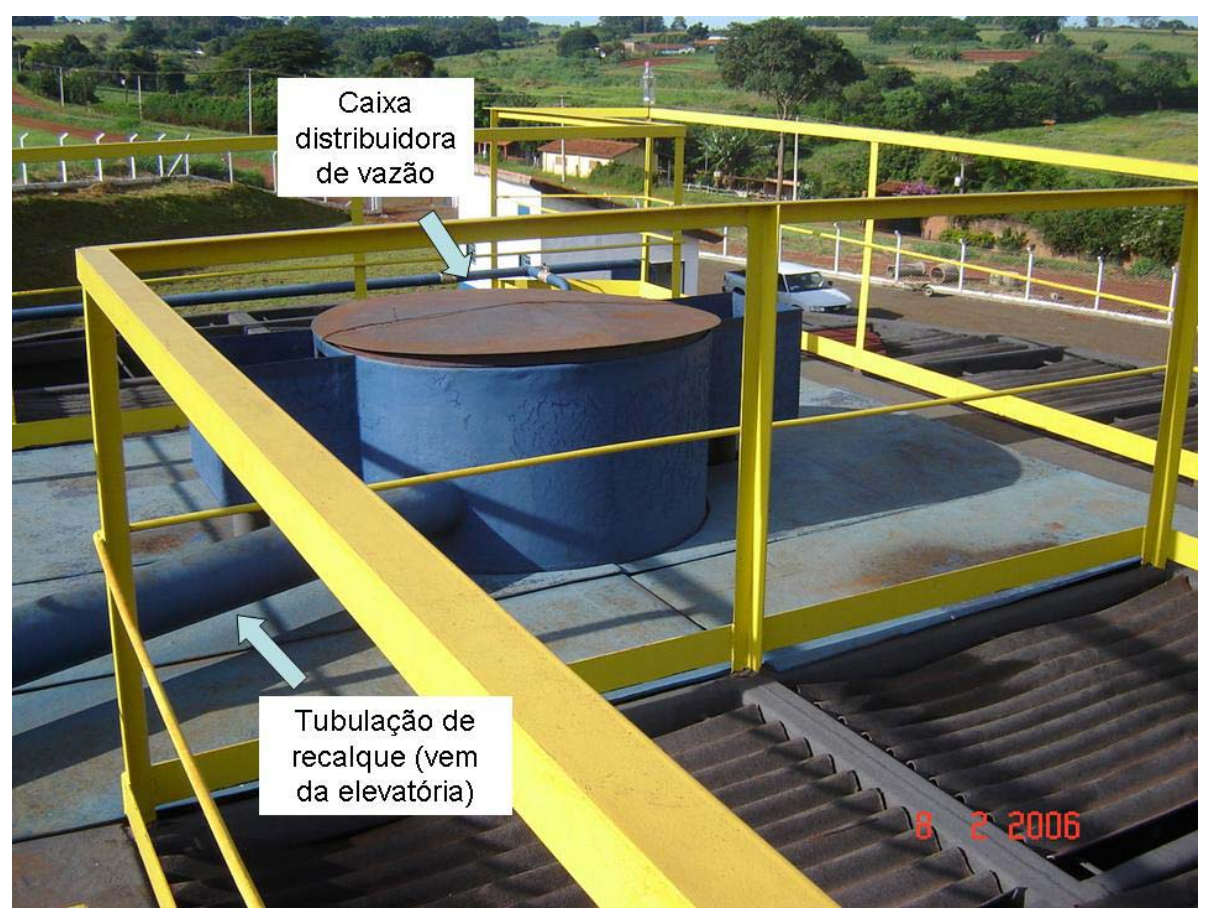

Figura 10 - Tubulação de recalque e caixa distribuidora de vazão. 
A Figura 11 mostra o afluente saindo da tubulação de recalque, sendo armazenado na caixa distribuidora de vazão e passando através do vertedor de entrada para a tubulação que conduz aos vertedores de distribuição.

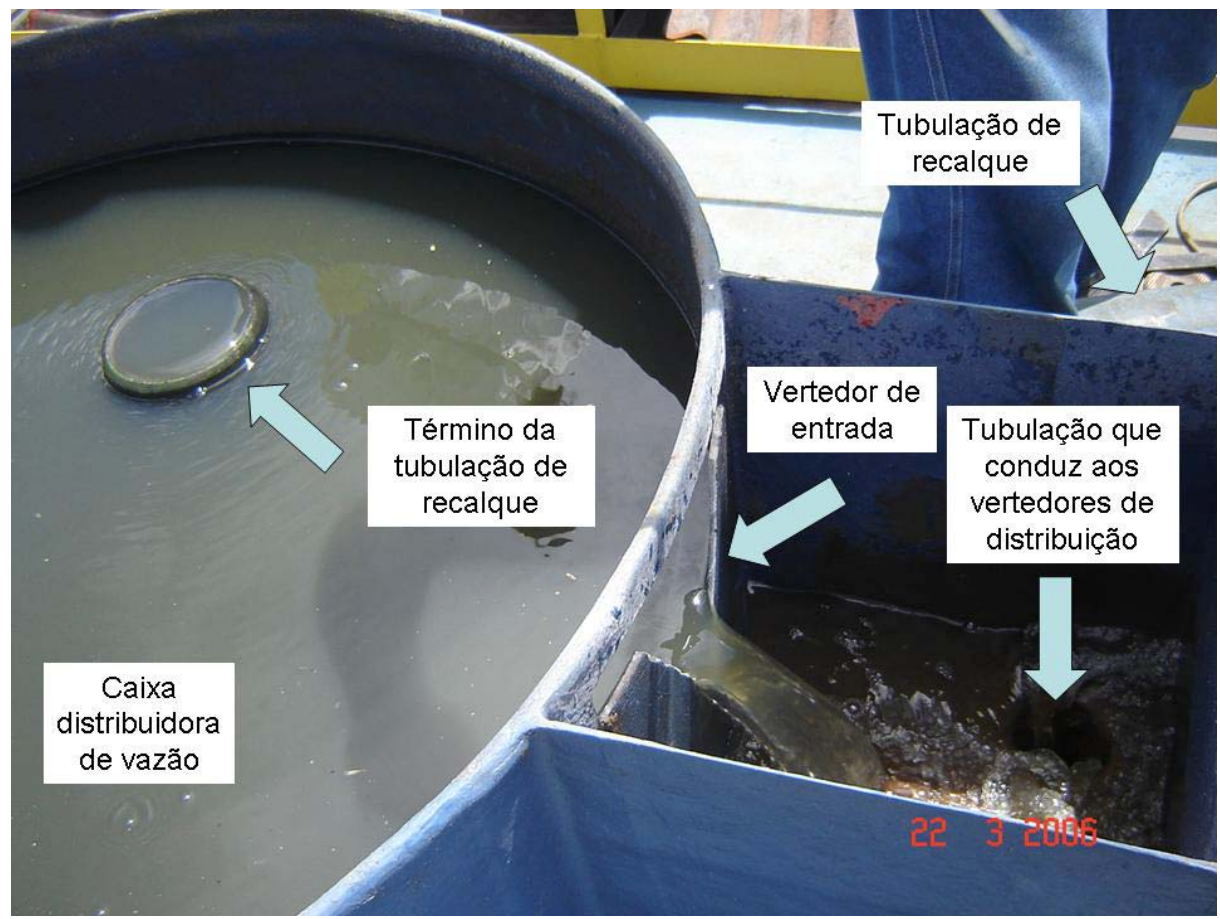

Figura 11 - Caixa distribuidora de vazão e vertedor de entrada.

A Figura 12 mostra os vertedores e os tubos de descida simetricamente distribuídos na superfície do reator que conduzem o afluente até o fundo do mesmo.

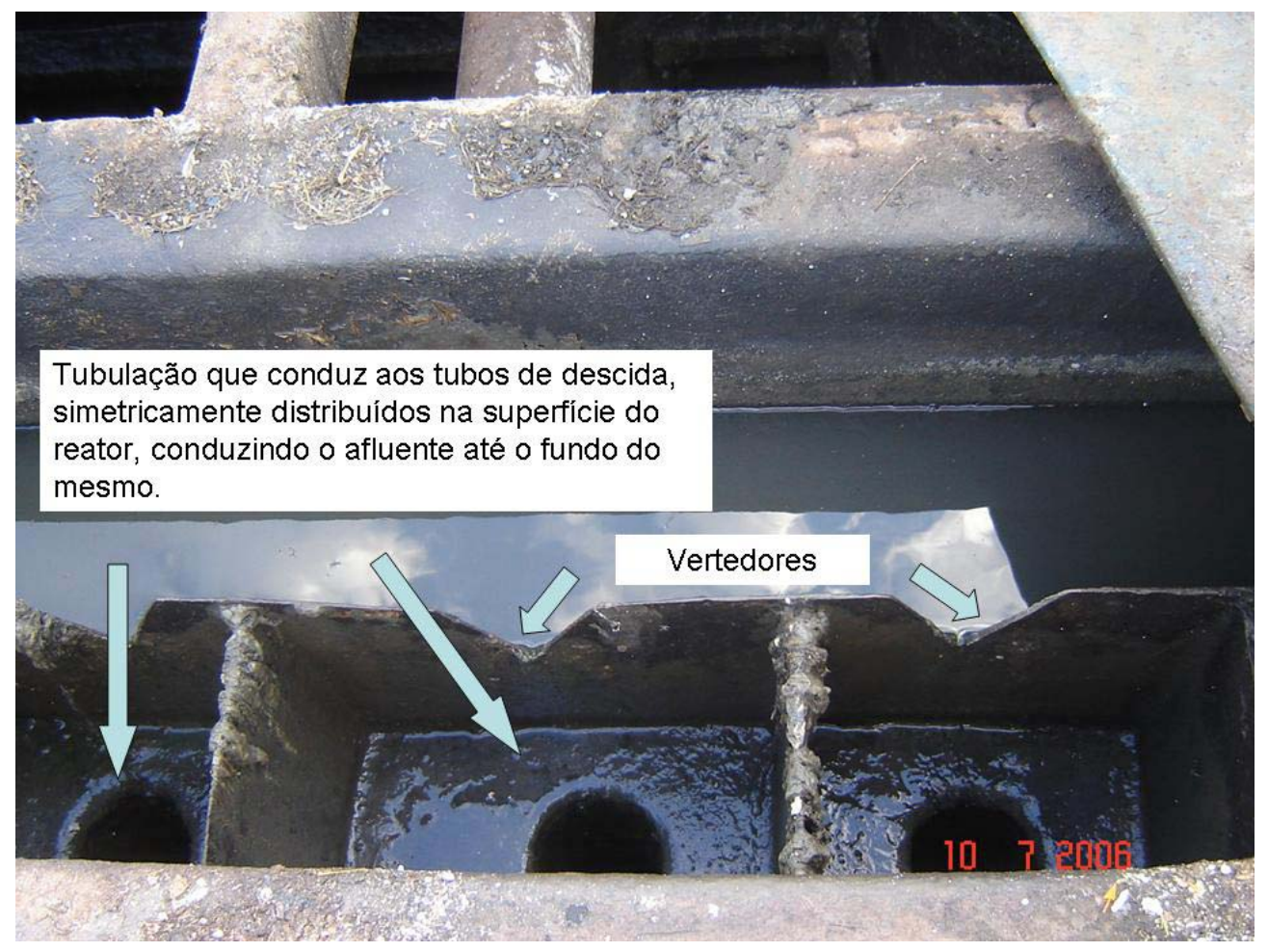

Figura 12 - Vertedores e tubulação que conduz ao fundo do reator. 
A Figura 13 mostra a tubulação de descida do gás coletado nas câmaras, que termina no queimador de gás (no detalhe). Também mostra a tubulação de amostragem do perfil de lodo ao longo da altura do reator, com suas respectivas alturas internas, além das válvulas de descarte do lodo excedente, simétricas nos dois compartimentos do reator. Em cada compartimento tem-se uma válvula que coleta o lodo excedente a $2 \mathrm{~m}$ de distância da parede do reator em direção ao centro e uma que coleta a 4,5 m, utilizando como referência a mesma parede. Ambas estão a $0,15 \mathrm{~m}$ de altura. $\mathrm{O}$ projeto previa uma válvula na altura de $1,20 \mathrm{~m}$, em cada compartimento, possibilitando o descarte de lodo em altura mais adequada (lodo com menor atividade quando comparado ao de fundo), mas na execução da obra foram instaladas apenas tubulações a $0,15 \mathrm{~m}$.

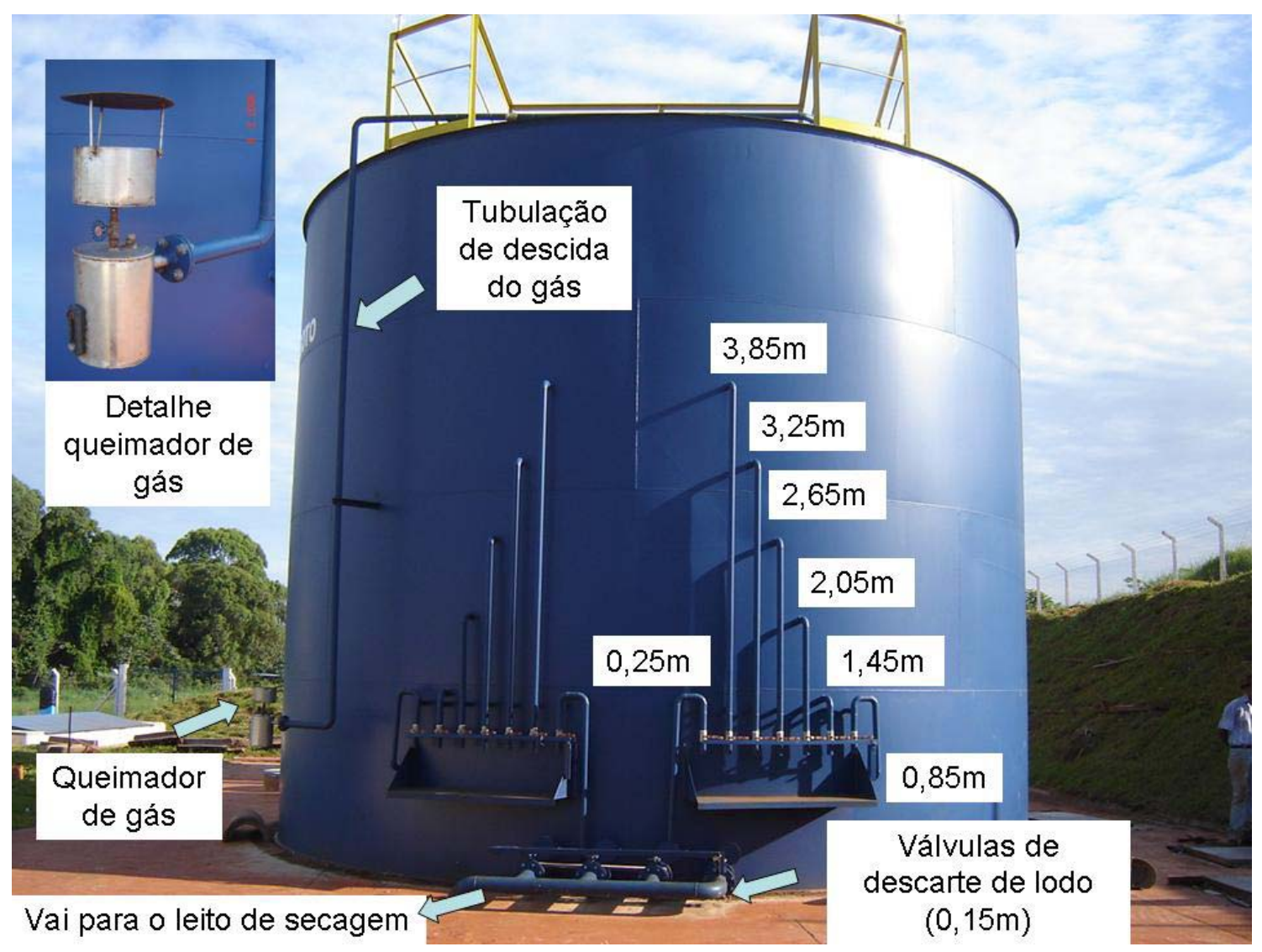

Figura 13 - Tubulação de gás, queimador, amostrador de lodo e válvulas de descarte de lodo.

A Figura 14 mostra uma vista interna do reator vazio, onde se pode observar a disposição das tulipas coletoras do efluente tratado, além da parte superior e lateral da câmara de gás. Pode notar também a parede inclinada do separador de fases. 


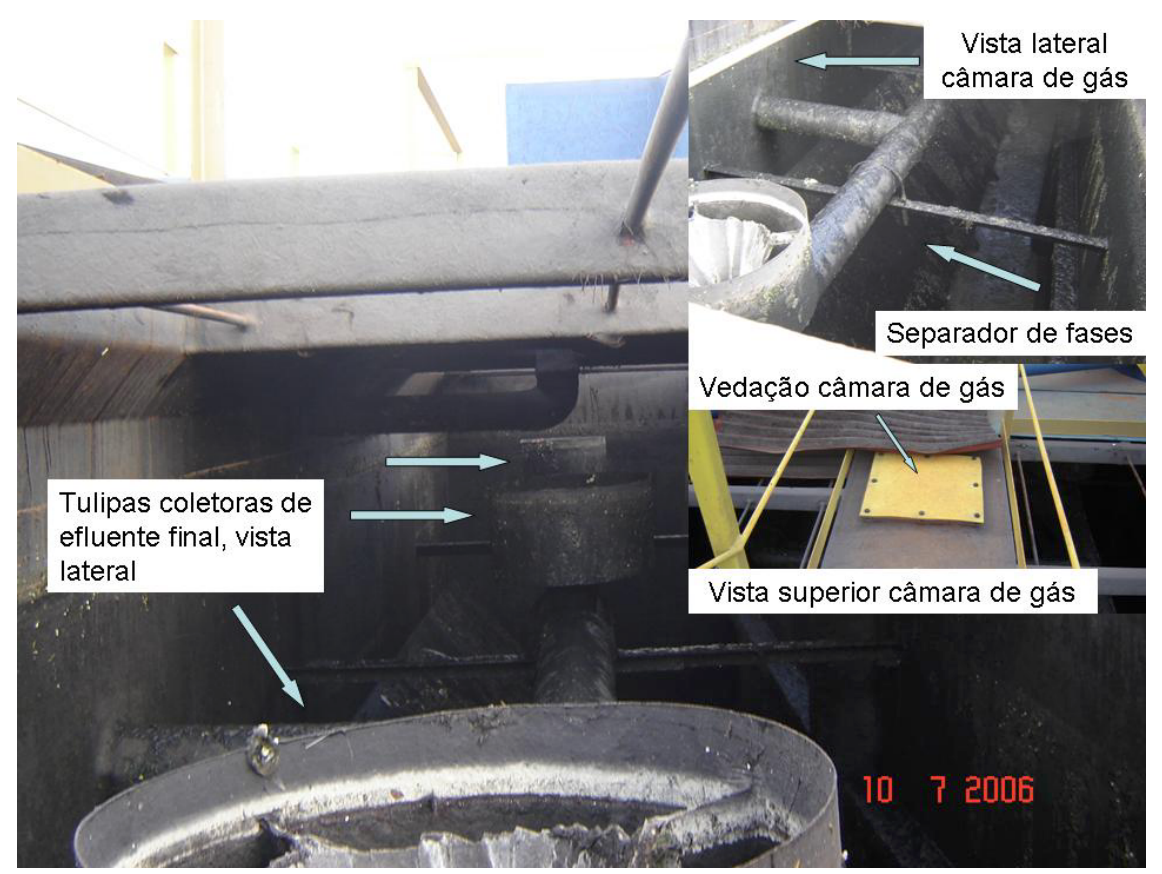

Figura 14 - Disposição das tulipas coletoras do efluente tratado, parte superior e lateral da câmara de gás e parede inclinada do separador de fases. 


\section{PROCEDIMENTOS EXPERIMENTAIS}

\subsection{Características operacionais das fases I e II da pesquisa}

A pesquisa foi dividida em duas fases: Fase I, sem adição de inóculo, e Fase II, com a adição de inóculo. Em ambas a fases usou-se apenas metade do volume do reator $\left(117 \mathrm{~m}^{3}\right)$, para que se dispusesse de menores TDHs e consequentemente maiores velocidades ascensionais. As características operacionais destas duas fases, bem como os dados de projeto do reator, estão apresentados na Tabela 7. Os dados correspondem a valores afluentes ao UASB.

Tabela 7 - Características operacionais de projeto e das Fases I e II da pesquisa.

\begin{tabular}{llll}
\hline \multirow{2}{*}{ Parâmetro } & Dados de projeto $^{(1)}$ & \multicolumn{2}{l}{ Dados operacionais } \\
\cline { 3 - 4 } & & Fase I & Fase II \\
Vazão média (L/s) & 8,15 & 5,5 & 6,9 \\
Vazão média (valores arredondados - m/dia) & 700 & 480 & 600 \\
TDH (horas) & 8 & 6 & 5 \\
DQO (mg/L) & 600 & 420 & 600 \\
DBO (mg/L) & 300 & 280 & 340 \\
COV (kgDQO/m 3 .dia) & & 1,74 & 2,88 \\
\hline
\end{tabular}


Tabela 7 - Características operacionais de projeto e das Fases I e II da pesquisa.

\begin{tabular}{llll}
\hline SST (mg/L) & 300 & 160 & 220 \\
Duração (dia) & - & 150 & 120 \\
Volume utilizado & 235 & 117 & 117 \\
no reator ( $\left.\mathrm{m}^{3}\right)$ & & \\
& \\
(1) Fonte: SANEVIX (2003). Os dados correspondem ao volume total do reator $\left(235 \mathrm{~m}^{3}\right)$, \\
o que explica a discrepância entre o TDH de projeto e o obtido nas fases I e II.
\end{tabular}

\subsection{Partida do reator UASB}

\section{$\underline{\text { FASE I }}$}

No início do experimento, a partida da Fase I foi dada ainda utilizando-se os dois compartimentos do reator $\left(235 \mathrm{~m}^{3}\right)$, pois, por medida de segurança, mantiveram-se os dois lados do reator preenchidos evitando diferenças de pressão entre as partes que poderiam ocasionar esforço excessivo nas paredes divisórias. Esta condição inicial proporcionou velocidade ascensional média de $0,4 \mathrm{~m} / \mathrm{h}$ e TDH médio de 11 horas. No entanto, este período foi considerado como parte da Fase I, devido à sua curta duração e ao fato das condições da Fase I (sem inóculo) propiciarem respostas muito lentas que, portanto, não acarretariam diferenças nos resultados.

No $47^{\circ}$ dia, passou-se, então, a operar com apenas metade do volume do reator, obtendo-se velocidade ascensional média de $0,94 \mathrm{~m} / \mathrm{h}$ e TDH médio de 6 horas, como previsto na proposta de pesquisa.

Nesta fase foi dada a partida sem a adição de inóculo. A alimentação foi iniciada com $800 \mathrm{~m}^{3}$ de efluente da TAM que estava armazenado em lagoas anaeróbias, naquela empresa. Este efluente possuía as características descritas na Tabela 8:

Tabela 8 - Características físico-químicas do efluente da TAM adicionado ao reator no início da Fase I.

\begin{tabular}{ll}
\hline Parâmetro & \\
\hline ST & $416 \mathrm{mg} / \mathrm{L}$ \\
STF & $0 \mathrm{mg} / \mathrm{L}$ \\
STV & $416 \mathrm{mg} / \mathrm{L}$ \\
\hline
\end{tabular}


Tabela 8 - Características físico-químicas do efluente da TAM adicionado ao reator no início da Fase I.

\begin{tabular}{ll}
\hline $\mathrm{pH}$ & 7 \\
Alcalinidade total & $50 \mathrm{mgCaCO} / \mathrm{L}$ \\
$\mathrm{DQO}$ & $520 \mathrm{mg} / \mathrm{L}$ \\
$\mathrm{DBO}$ & $160 \mathrm{mg} / \mathrm{L}$ \\
Ácido acético & $20 \mathrm{mg} / \mathrm{L}$ \\
Ácido propiônico & $5 \mathrm{mg} / \mathrm{L}$ \\
Ácido isobutírico & $1 \mathrm{mg} / \mathrm{L}$ \\
Ácido butírico & $1 \mathrm{mg} / \mathrm{L}$ \\
Ácido isovalérico & $2 \mathrm{mg} / \mathrm{L}$ \\
Ácido valérico & $0,5 \mathrm{mg} / \mathrm{L}$ \\
Ácido capróico & $0,5 \mathrm{mg} / \mathrm{L}$ \\
\hline
\end{tabular}

Em seguida procedeu-se à alimentação contínua do reator com a vazão de $480 \mathrm{~m}^{3} /$ dia e carga orgânica volumétrica de $1,74 \mathrm{kgDQO} / \mathrm{m}^{3}$.dia. No entanto, nesta fase ainda não se dispunha de controle da vazão afluente, o que resultou em oscilações da entrada de esgoto bruto de 3 a $25 \mathrm{~L} / \mathrm{s}$. O TDH médio foi de 6 horas. Esta fase durou aproximadamente 150 dias.

\section{$\underline{\text { FASE II }}$}

Para a Fase II da pesquisa, o reator foi esvaziado até a metade de seu volume, já que este era o volume máximo permitido pela capacidade de armazenamento dos leitos de secagem. Foram então adicionados $12 \mathrm{~m}^{3}$ de lodo anaeróbio proveniente do reator UASB da ETE Flores - Rio Claro (SP).

Devido a problemas no transporte, foram adicionados primeiramente $6 \mathrm{~m}^{3} \mathrm{de}$ lodo e os $6 \mathrm{~m}^{3}$ restantes dezessete horas depois. O lodo permaneceu em repouso por mais 24 horas, quando então iniciou-se a alimentação com esgoto até que se atingisse $70 \%$ do volume do reator, operação seguida por mais 24 horas de repouso. Após este período, foi preenchido o volume útil do reator com esgoto e iniciada a operação com vazão média de $600 \mathrm{~m}^{3} / \mathrm{dia}$, correspondente a uma carga orgânica volumétrica de $2,88 \mathrm{kgDQO} / \mathrm{m}^{3}$.dia. Embora não fosse objetivo da pesquisa modificar a vazão aplicada (e conseqüentemente o TDH e a COV) de uma fase para outra, alguns parâmetros não 
são controláveis por se tratar de uma ETE real sujeita às variações impostas pela vazão afluente. Esta fase foi acompanhada por aproximadamente 120 dias. O TDH médio foi de 4 horas, com mínimos de 2,6 horas e máximos de 8,0 horas.

\subsubsection{Inóculo}

Para análise do inóculo a ser utilizado foi feita microscopia óptica e teste de atividade metanogênica, adaptado de Penna (1994), como descrito a seguir.

Determinou-se a concentração de SSV da amostra de lodo. Esta correspondia a $7 \mathrm{~g} / \mathrm{L}$ no início e no fim do teste, mostrando que não ocorreu perda de biomassa durante o experimento.

O lodo permaneceu em repouso por 12 horas a $4{ }^{\circ} \mathrm{C}$ antes do prosseguimento da análise.

Foi utilizado frasco-reator de $350 \mathrm{~mL}$, diferente do volume de Penna (1994), por ser o material disponível no laboratório.

Foram feitas duas análises, uma avaliando a produção de metano utilizando como substrato esgoto proveniente da própria ETE Água Vermelha e outra utilizando acetato como substrato.

No reator de ESGOTO, foram adicionados apenas $150 \mathrm{~mL}$ do lodo de inóculo e $150 \mathrm{~mL}$ do esgoto.

No reator de ACETATO foram adicionados $250 \mathrm{~mL}$ de lodo, 0,25 mL de solução traço de metais (PENNA, 1994) e 2,5 mL de acetato de sódio.

Foi, então, borbulhado nitrogênio por cinco minutos em cada frasco, que foi em seguida vedado e levado para estufa a $30^{\circ} \mathrm{C}$.

A agitação do meio foi manual e feita apenas imediatamente antes de cada medida de metano.

Após dez minutos foram iniciadas as leituras de metano, com intervalos de vinte minutos entre elas, até que se iniciasse o decaimento da curva de produção.

As leituras foram feitas em cromatógrafo Gow-Mac série 150, injetando 0,5 mL de amostra de gás coletada com seringa do tipo "gas-tight".

As quantidades de metano registradas pelo aparelho foram transformadas para número de mols através da eq. (5): 


$$
Y=14712121051,48 * X+8407,82
$$

Foi então transformado o valor em mol para litros através da relação: $1 \mathrm{~mol}=$ 22,4 L (para temperatura de $0{ }^{\circ} \mathrm{C}$ e pressão de $1 \mathrm{~atm}$ ). A conversão de litros para gramas de DQO consumida (gDQOcons.) foi feita através da relação citada por Penna (1994) para a pressão de $700 \mathrm{mmHg}$ (referente à cidade de São Carlos, SP), a $30{ }^{\circ} \mathrm{C}$ : 1 gDQOcons. $=422 \mathrm{~mL}^{\text {de } \mathrm{CH}_{4}}$.

Este valor foi, então, dividido pela quantidade de SSV obtida do frasco ao término do ensaio, obtendo assim a relação em gDQO cons./gSSV.

Desenhou-se um gráfico do valor acumulado desta última relação versus o tempo em dias (curva de atividade metanogênica).

Foi determinado, então, o primeiro trecho retilíneo de inclinação máxima da curva com no mínimo quatro pontos, ajustado por regressão linear, obtendo-se a equação da reta correspondente.

O coeficiente angular desta reta resulta na atividade metanogênica específica.

A quantidade de inóculo necessária ao reator foi calculada segundo Chernicharo (1997).

Embora a literatura recomende a introdução do lodo preferencialmente no fundo do reator com auxílio de mangote de caminhões limpa-fossas, nesta pesquisa, o mangote teve que ser fixado na parte superior do reator e pôde introduzir o lodo apenas a aproximadamente 1 metro de profundidade, devido às restrições físicas do reator e do mangote, como pode ser observado na Figura 15.

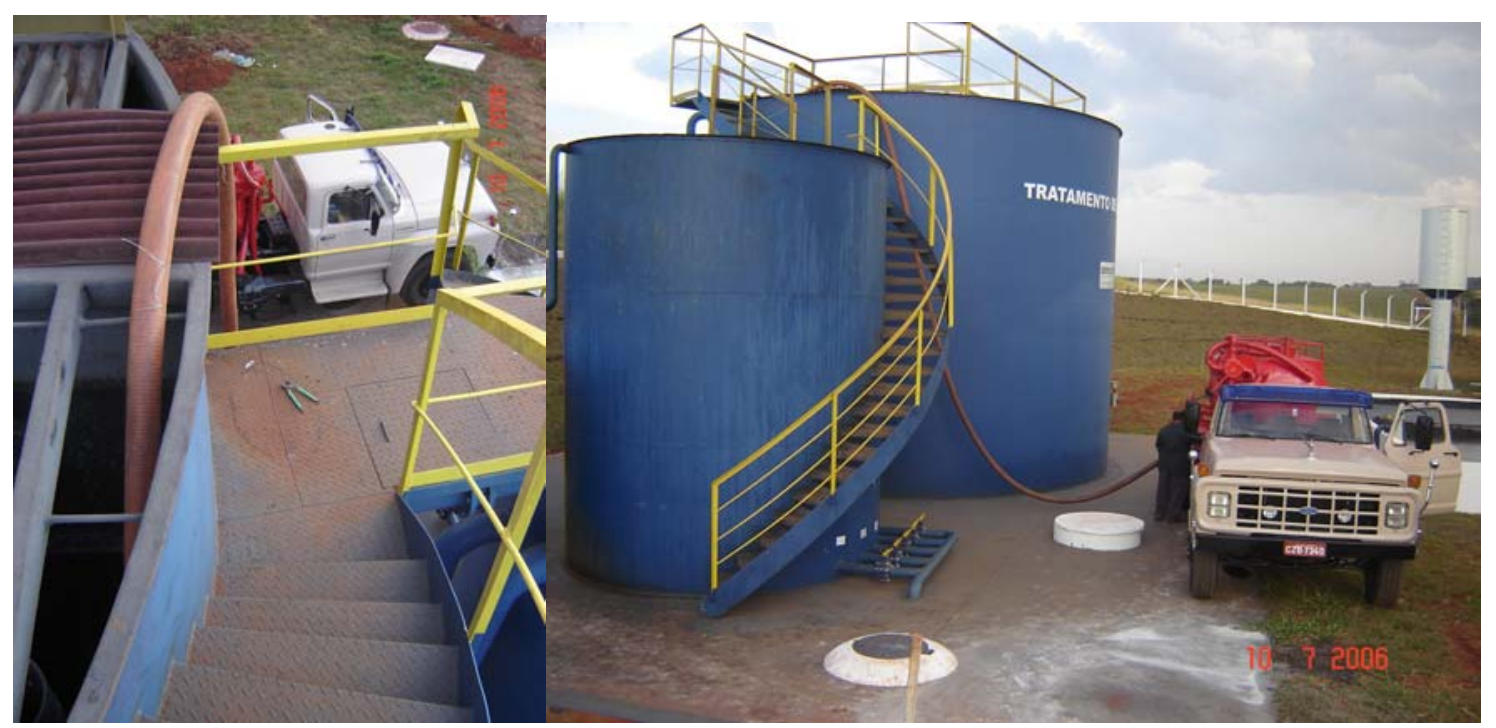

Figura 15 - Mangote do caminhão limpa-fossas preso à parte superior do reator e vista geral do caminhão e reator durante a inoculação. 


\subsection{Avaliação dos parâmetros físico-químicos}

Os parâmetros físico-químicos, pontos de amostragem e freqüência estão discriminados na Tabela 9.

Tabela 9 - Parâmetros físico-químicos e pontos de amostragem.

\begin{tabular}{|c|c|c|c|c|}
\hline Parâmetro & Método & $\begin{array}{l}\text { Pontos de } \\
\text { amostragem }\end{array}$ & Freqüência & $\begin{array}{l}\text { Referência } \\
\text { Bibliográfica }\end{array}$ \\
\hline Temperatura & $2550 \mathrm{~B}$ & $\begin{array}{l}\text { Entrada/Saída do } \\
\text { reator }\end{array}$ & Semanal & $\begin{array}{l}\text { APHA et al. } \\
\text { (1999) }\end{array}$ \\
\hline $\mathrm{pH}$ & Potenciométrico & $\begin{array}{l}\text { Entrada/Saída do } \\
\text { reator }\end{array}$ & Semanal & \\
\hline $\begin{array}{l}\text { DQO } \\
\text { bruta/filtrada }\end{array}$ & $5220 \mathrm{D}$ & $\begin{array}{l}\text { Entrada/Saída do } \\
\text { reator }\end{array}$ & Semanal & $\begin{array}{l}\text { APHA et al. } \\
\text { (1999) }\end{array}$ \\
\hline $\begin{array}{l}\mathrm{DBO}_{5} \\
\text { bruta/filtrada }\end{array}$ & $5210 \mathrm{~B}$ & $\begin{array}{l}\text { Entrada/Saída do } \\
\text { reator }\end{array}$ & Semanal & $\begin{array}{l}\text { APHA et al. } \\
\text { (1999) }\end{array}$ \\
\hline $\begin{array}{l}\text { Nitrogênio } \\
\text { Total Kjeldahl }\end{array}$ & $4500-\mathrm{N}_{\text {org }} \mathrm{B}$ & $\begin{array}{l}\text { Entrada/Saída do } \\
\text { reator }\end{array}$ & Semanal & $\begin{array}{l}\text { APHA et al. } \\
\text { (1999) }\end{array}$ \\
\hline $\begin{array}{l}\text { Nitrogênio } \\
\text { amoniacal }\end{array}$ & $\begin{array}{l}4500-\mathrm{NH}_{3} \mathrm{~B} \\
4500-\mathrm{NH}_{3} \mathrm{C}\end{array}$ & $\begin{array}{l}\text { Entrada/Saída do } \\
\text { reator }\end{array}$ & Semanal & $\begin{array}{l}\text { APHA et al. } \\
\text { (1999) }\end{array}$ \\
\hline Fósforo total & 4500-P & $\begin{array}{l}\text { Entrada/Saída do } \\
\text { reator }\end{array}$ & Semanal & $\begin{array}{l}\text { APHA et al. } \\
\text { (1999) }\end{array}$ \\
\hline $\begin{array}{l}\text { Alcalinidade } \\
\text { parcial e total }\end{array}$ & $2320 \mathrm{~B}$ & $\begin{array}{l}\text { Entrada/Saída do } \\
\text { reator }\end{array}$ & Semanal & $\begin{array}{l}\text { APHA et al. } \\
\text { (1999) }\end{array}$ \\
\hline \multirow{5}{*}{$\begin{array}{l}\text { Série de } \\
\text { sólidos }\end{array}$} & $2540 \mathrm{~B}$ & $\begin{array}{l}\text { Entrada/perfil/Saída } \\
\text { do reator }\end{array}$ & Semanal & \\
\hline & $2540 \mathrm{D}$ & $\begin{array}{l}\text { Entrada/perfil/Saída } \\
\text { do reator }\end{array}$ & Semanal & \multirow{4}{*}{$\begin{array}{l}\text { APHA et al. } \\
(1999)\end{array}$} \\
\hline & $2540 \mathrm{E}$ & $\begin{array}{l}\text { Entrada/perfil/Saída } \\
\text { do reator }\end{array}$ & Semanal & \\
\hline & & Inóculo & Início Fase II & \\
\hline & $2540 \mathrm{Fa}$ & Perfil do reator & Quinzenal & \\
\hline \multirow{2}{*}{$\begin{array}{l}\text { Vazão } \\
\text { afluente } \\
\text { Ácidos } \\
\text { voláteis }\end{array}$} & (1) & Entrada do reator & Semanal & \multirow[t]{2}{*}{$\begin{array}{l}\text { SANEVIX } \\
(2003)\end{array}$} \\
\hline & $\begin{array}{l}\text { Cromatografia a } \\
\text { gás }\end{array}$ & $\begin{array}{l}\text { Entrada/Saída do } \\
\text { reator }\end{array}$ & Semanal & \\
\hline MEV & & Leito de lodo & $\begin{array}{l}\text { Metade da } \\
\text { Fase II }^{(2)}\end{array}$ & $\begin{array}{l}\text { Araújo (1995) } \\
\text { e Nation } \\
(1983)\end{array}$ \\
\hline $\mathrm{COT}_{\mathrm{f}}$ & $5310 \mathrm{~A}$ & $\begin{array}{l}\text { Entrada/Saída do } \\
\text { reator }\end{array}$ & Semanal & $\begin{array}{l}\text { APHA et al. } \\
\text { (1999) }\end{array}$ \\
\hline $\mathrm{NO}_{3}^{-2}$ & $4500-\mathrm{NO}_{3}{ }^{-} \mathrm{A}$ & $\begin{array}{l}\text { Entrada/Saída do } \\
\text { reator }\end{array}$ & Semanal & $\begin{array}{l}\text { APHA et al. } \\
\text { (1999) }\end{array}$ \\
\hline $\mathrm{NO}_{2}^{-2}$ & $4500-\mathrm{NO}_{2}^{-} \mathrm{B}$ & $\begin{array}{l}\text { Entrada/Saída do } \\
\text { reator }\end{array}$ & Semanal & $\begin{array}{l}\text { APHA et al. } \\
\text { (1999) }\end{array}$ \\
\hline
\end{tabular}


Tabela 9 - Parâmetros físico-químicos e pontos de amostragem.

\begin{tabular}{|c|c|c|c|c|}
\hline $\begin{array}{l}\text { Composição do } \\
\text { Biogás }\end{array}$ & $\begin{array}{l}\text { Cromatografia } \\
\text { a gás }\end{array}$ & Biogás & Semanal & \\
\hline \multirow[b]{2}{*}{$\begin{array}{l}\text { Microscopia } \\
\text { óptica }\end{array}$} & & Inóculo & $\begin{array}{l}\text { Inicio da Fase } \\
\text { II }\end{array}$ & \\
\hline & & $\begin{array}{l}\text { Leito e manta } \\
\text { de lodo } \\
(0,25 \mathrm{~m})\end{array}$ & $\begin{array}{l}\text { Metade e final } \\
\text { da Fase II }\end{array}$ & \\
\hline \multirow{2}{*}{$\begin{array}{l}\text { Atividade } \\
\text { metanogênica } \\
\text { específica }\end{array}$} & & Inóculo & Início Fase II & \multirow[b]{2}{*}{ Penna (1994) } \\
\hline & & $\begin{array}{l}\text { Leito de lodo } \\
(0,25 \mathrm{~m})\end{array}$ & Final da Fase II & \\
\hline
\end{tabular}

(1) A medição da altura da lâmina d'água foi feita com auxílio de régua posicionada verticalmente dentro do vertedor triangular da caixa distribuidora de vazão. Este tipo de medida pode representar vazão até $20 \%$ inferior à vazão real. O ângulo de abertura do vertedor de entrada é de $120^{\circ}$.

(2) após a observação por MEV nesta etapa concluiu-se que era desnecessária sua repetição ao final da Fase II, pois as imagens de microscopia óptica visualizadas ao final da Fase II eram muitos semelhantes às da metade desta fase.

As equações utilizadas para o cálculo da vazão no vertedor triangular de parede fina, eq. (6) e (7), foram as citadas em Porto (2004) conforme transcritas abaixo.

$Q=\frac{8}{15} C d \sqrt{2 g} \operatorname{tg}(\alpha / 2) h^{\frac{5}{2}}$

Cd: coeficiente de vazão;

g: aceleração da gravidade $\left(\mathrm{m} / \mathrm{s}^{2}\right)$;

$\alpha$ : ângulo de abertura do vertedor $\left({ }^{\circ}\right)$;

h: altura da lâmina líquida (m).

Para o cálculo do coeficiente de vazão $(\mathrm{Cd})$, foi aplicada a fórmula de Kindsvater \& Cater:

$C d=\left(0,602+0,075 \frac{h}{P}\right)$

P: a altura da soleira (m). 


\subsection{1 - Rotina de monitoramento}

O monitoramento de rotina do UASB foi feito por amostras compostas e simples, coletadas semanalmente. Nas amostras compostas foram coletadas alíquotas de hora em hora, das 8 às 16 horas, na entrada e na saída do reator, com volume proporcional à vazão afluente ao reator no momento da coleta, até completar 8 amostras. Cada alíquota era preservada a $4{ }^{\circ} \mathrm{C}$, até que pudessem ser misturadas em uma única amostra composta de 5 litros.

Também foram feitas coletas de amostras simples, com freqüência de 1 amostra/hora, totalizando $8 \mathrm{em}$ um dia. Cada amostra simples era coletada num frasco de $100 \mathrm{~mL}$. Esta amostragem teve por objetivo conhecer o desempenho do processo face à variação no tempo da vazão afluente e das características do esgoto. A única variável medida nas amostras simples foi a DQO.

A coleta de afluente era feita diretamente do vertedor da caixa de distribuição. A coleta do efluente líquido era feita na tulipa coletora, através do coletor chamado "bailer". A coleta do biogás era feita com o coletor de vidro, que era previamente preenchido com água. Abrindo-se as presilhas metálicas, esta água era expelida dando lugar ao biogás, que era então aprisionado no coletor. A Figura 16 ilustra os materiais e os pontos de coleta utilizados.

A medição de vazão era feita todas as vezes que a bomba era acionada, aferindose a vazão de pico e monitorando-se o tempo e as vazões até que a entrada de afluente cessasse. Era então contabilizado o tempo que a bomba permanecia desligada e assim desenhados os hidrogramas. 


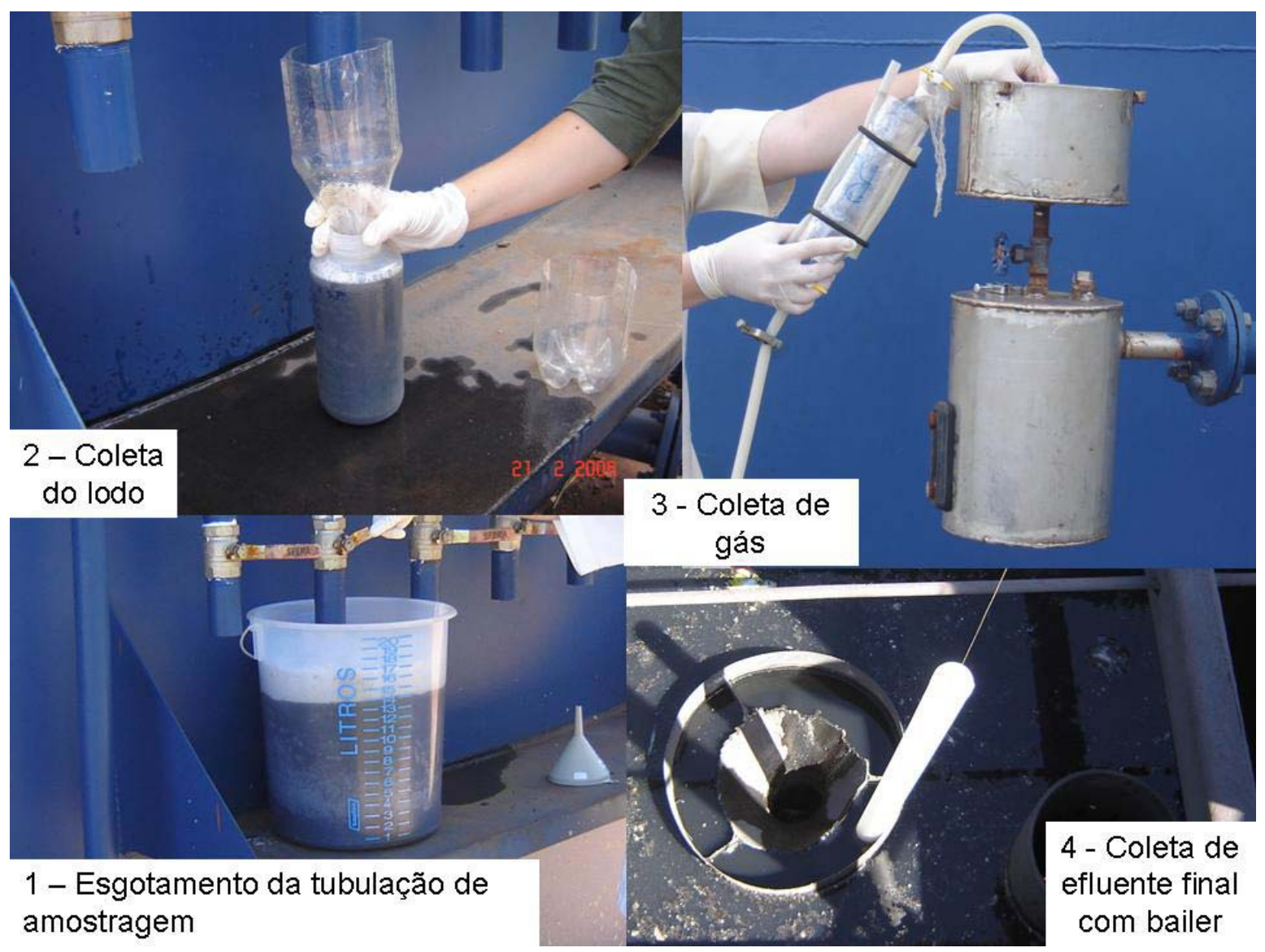

Figura 16 - Pontos de coleta e materiais utilizados.

Foram realizadas determinações semanais de temperatura, $\mathrm{pH}, \mathrm{DQO}$ e $\mathrm{DBO}_{5}$ de amostras filtradas e não filtradas, COT filtrado, NTK, N-amoniacal, P-total, nitritos, nitratos, alcalinidade parcial e total, série de sólidos, vazão afluente horária e ácidos voláteis. Foram realizadas análises esporádicas de metais pesados devido à suspeita de possíveis lançamentos de efluente proveniente de galvanoplastia na rede coletora no distrito de Água Vermelha, para se certificar de que não havia concentrações destes metais que pudessem causar inibição do processo.

As análises da série de sólidos, para acompanhamento da formação do leito e da manta de lodo, foram feitas nos sete pontos de amostragem, estando estes a 0,$25 ; 0,85$; 1,$45 ; 2,05 ; 2,65 ; 3,25$ e 3,85 metros da base (figura 13 ).

\subsection{2 - Cromatografia a gás para ácidos voláteis}

A concentração dos ácidos voláteis no afluente e efluente do reator foram determinadas por cromatografia a gás. Foi usado o cromatógrafo HP 6890 com detector de ionização de chama (FID) e coluna HP INNOWAX com $30 \mathrm{~m}$ de comprimento, 
$0,25 \mathrm{~mm}$ de diâmetro interno e $0,25 \mu \mathrm{m}$ de espessura do filme. $\mathrm{O}$ gás de arraste foi o hidrogênio, com fluxo de 2,0 $\mathrm{mL} / \mathrm{min}$. Injetava-se um volume de $1,0 \mu \mathrm{L}$, com razão de "split" de 20. A temperatura de injeção era de $250{ }^{\circ} \mathrm{C}$. O forno operava a temperatura variável, começando com $100{ }^{\circ} \mathrm{C}$ por 3 minutos, depois subindo a uma velocidade constante de $5{ }^{\circ} \mathrm{C}$ por minuto até atingir os $180^{\circ} \mathrm{C}$, temperatura esta mantida por mais 5 minutos. O detector operava a uma temperatura de $300{ }^{\circ} \mathrm{C}$, com um fluxo de ar sintético (300 mL/min), de nitrogênio (33 $\mathrm{mL} / \mathrm{min}$, para o "make-up") e de hidrogênio (30 $\mathrm{mL} / \mathrm{min}$, para alimentar a chama do detector).

A metodologia utilizada permitiu a quantificação dos ácidos acético, propiônico, isobutírico, butírico, isovalérico, valérico e capróico.

\subsection{3 - Cromatografia a gás para o biogás}

A composição do biogás em termos de nitrogênio, metano e gás carbônico foi determinada com o uso de cromatografia a gás.

Foi utilizado o cromatógrafo a gás Gow-Mac série 150, com detector de condutividade térmica de $150 \mathrm{~mA}$ e temperatura de $70^{\circ} \mathrm{C}$, coluna de aço inox com 2,0 m de comprimento por $1 / 4$ " de diâmetro interno, preenchida com Porapak Q 80-100 Mesh, usando hidrogênio como gás de arraste, com fluxo de arraste de $60 \mathrm{~mL} / \mathrm{min}$, em forno a $50^{\circ} \mathrm{C}$.

As amostras eram retiradas com uma seringa do tipo "gas-tight" da mangueira de borracha do coletor ilustrado na Figura 16, da extremidade por onde o gás entrou. Para remover o ar residual a seringa era "lavada" três vezes com o próprio biogás. Coletava-se, então, $1 \mathrm{~mL}$ de biogás que era injetado no cromatógrafo.

A porcentagem de cada gás foi calculada com base na área do cromatograma (valor em mmol fornecido na leitura do aparelho), de acordo com as eq. (8), (9) e (10), fornecidas pelo Laboratório de Processos Biológicos (LPB) da EESC/USP. Os símbolos $\% \mathrm{~N}_{2}, \% \mathrm{CH}_{4}$ e $\% \mathrm{CO}_{2}$ representam respectivamente a porcentagem de nitrogênio, metano e gás carbônico na amostra.

$$
\% N_{2}=\frac{\text { área_cromatograma }}{761313}
$$




$$
\begin{aligned}
& \% \mathrm{CH}_{4}=\frac{\text { área_cromatograma }-8407,82}{14712121051,48} \\
& \% \mathrm{CO}_{2}=\frac{\text { área_cromatograma }}{857423}
\end{aligned}
$$

As amostragens de biogás foram feitas semanalmente.

\subsection{4 - Volume de biogás}

Não foi possível a quantificação do volume de biogás produzido. O sistema não dispõe de medidor de vazão de biogás gerado e o fato de, na coleta no biogás, para avaliação de sua composição, notar-se que este chegava em pequenas quantidades pela tubulação de coleta, desencorajou a instalação de sistema de medição de vazão, antes que fossem providenciadas a cobertura do reator e a perfeita vedação das tampas da câmara de gás, intervenções que se espera futuramente sejam realizadas.

\subsection{5 - Microscopia óptica}

Foi utilizado microscópio LEICA DMLB acoplado a câmara com captura de imagem e software Image-Pro Plus. As lâminas foram preparadas com ágar para a fixação de uma gota de amostra (coletada em pipeta de Pasteur) e recobertas com uma lamínula.

Foi feita microscopia óptica de contraste de fase e fluorescência, no inóculo (na ocasião da partida) e no leito e manto de lodo do reator com 225 dias de operação (63 dias após a inoculação) e ao término do experimento.

A microscopia de fluorescência permite identificar as arquéias metanogênicas (com exceção do gênero Methanosaeta, que não fluoresce) sem a necessidade de preparações especiais.

\subsection{6 - Microscopia eletrônica de varredura}

Foram feitas imagens no microscópio eletrônico de varredura (MEV), de amostra do leito de lodo, mesmo sem a ocorrência da formação de grânulos, esperando- 
se alguma contribuição de visualização de espécies presentes mesmo que não arranjadas em grânulos. A metodologia utilizada foi a descrita em Araújo (1995) e Nation (1983).

As amostras a serem observadas foram mergulhadas em glutaraldeído 2,5 \% por 12 horas. Foram lavadas com solução tampão fosfato $0,1 \mathrm{M}$, em três banhos de 10 minutos cada. Em seguida, foram desidratadas por banhos sucessivos em soluções de álcool de concentrações crescentes: $50 \%, 70 \%, 80 \%, 90 \%, 95 \%$ e $100 \%$. Para cada concentração foi dado um banho de 10 minutos nas amostras, com exceção da concentração de $100 \%$, para a qual foram usados três banhos de 10 minutos cada. Foram então secas em placa de Petri na estufa por duas horas e então fixadas nos suportes próprios para MEV utilizando esmalte de unhas incolor. Por fim, as amostras foram secas em estufa a $30^{\circ} \mathrm{C}$ por duas horas.

A Figura 17 mostra as amostras já no suporte próprio para MEV antes de receber o banho de ouro. As britas em segundo plano na foto são para visualização do biofilme formado sobre o meio suporte do BAS da ETE Água Vermelha.

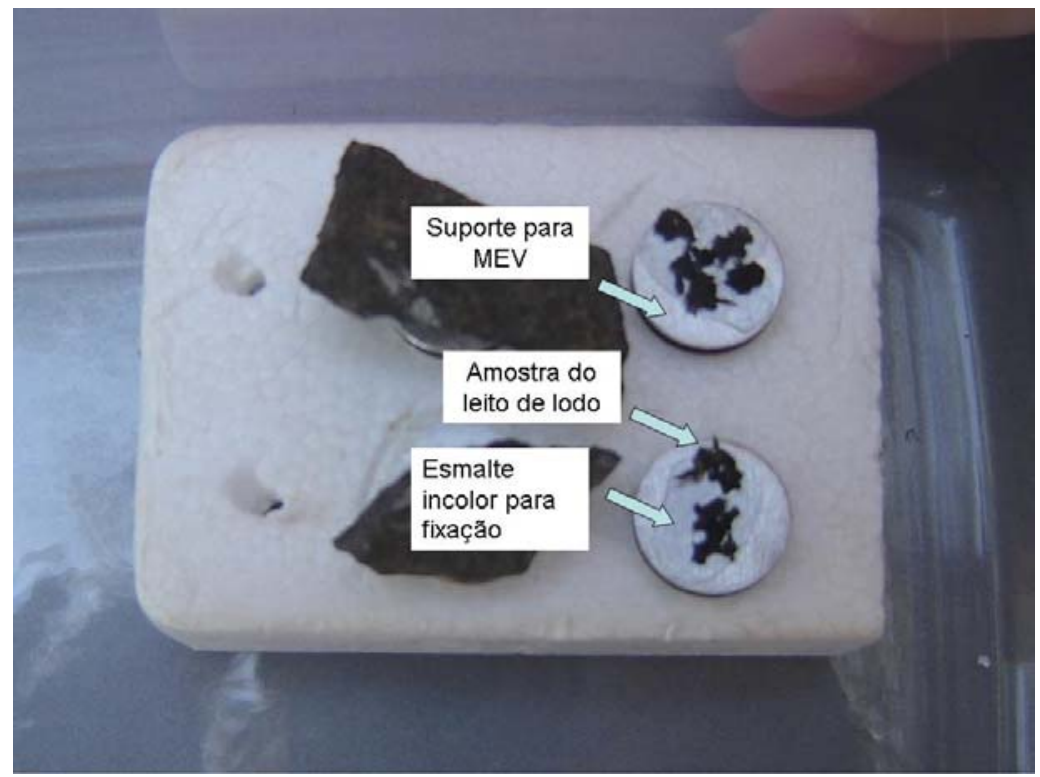

Figura 17 - Amostras prontas para receber o banho de ouro antes da observação.

Depois de prontas, as amostras foram encaminhadas ao Instituto de Física de São Carlos (IFSC) da EESC/USP, para receberem o banho de ouro, que as torna condutoras de eletricidade e permite a formação de imagens nos microscópios eletrônicos de varredura. Onde foi feita também a visualização do microscópio eletrônico de varredura Zeiss DSM-960. 


\subsection{7 - Descarte de lodo}

O critério para o descarte de lodo foi a expansão da manta até a maior altura de amostragem (3,85 m), observando a qualidade do efluente produzido. As determinações da altura da manta de lodo eram feitas nos horários de pico de vazão.

O descarte foi realizado através da abertura de um registro situado na tubulação, que se acreditava estar instalada a 1,20 m de altura em relação ao fundo do reator. No entanto, posteriormente constatou-se que esta tubulação estava na verdade instalada a $0,15 \mathrm{~m}$ de altura, diferentemente da especificação de projeto. O lodo foi então encaminhado para o leito de secagem, onde foi submetido a higienização com cal e permaneceu por 30 dias.

\subsection{8 - Retorno de lodo do BAS para o UASB}

Semanalmente ocorreu a lavagem do BAS, quando aproximadamente $5 \mathrm{~m}^{3}$ eram recirculados para o UASB, através da estação elevatória.

\subsection{9 - Lançamento de lodo de fossas na ETE Água Vermelha}

O lodo lançado na ETE é proveniente de um bairro, situado no distrito de Água Vermelha, com aproximadamente 120 chácaras, que não possui rede coletora de esgoto. Um trator com reservatório acoplado de $3 \mathrm{~m}^{3}$ de capacidade faz a limpeza de seis a oito chácaras por dia e lança este material no poço de visita da rede coletora de esgotos da estrada que dá acesso à estação de tratamento. Estes lançamentos ocorrem em torno de três vezes na semana, totalizando 50 a $70 \mathrm{~m}^{3}$ semanais.

Ressalta-se que este material não se constitui de lodo digerido de fossas sépticas, pois, na verdade, estas fossas não são vedadas e recebem água pluvial infiltrada no terreno, pois o bairro situa-se numa região alagadiça com lençol freático bastante próximo à superfície. Por esta razão a limpeza é feita com tanta freqüência e o material coletado é uma mistura de lodo, efluente, água pluvial e solo carreado. Estes lançamentos não estavam previstos no projeto da ETE e não são autorizados. No mês de dezembro de 2006, ocasião em que a fase experimental da pesquisa estava concluída, os lançamentos foram finalmente proibidos e transferidos para uma lagoa desativada na própria ETE, que fazia parte do sistema de tratamento antes da reforma. 


\subsection{Análise estatística dos dados de DQO}

A avaliação estatística dos dados de DQO foi feita sobre os dados coletados nas segundas e terças-feiras, devido a estes serem os dias com maior quantidade de coletas. Isto se deve ao fato das coletas a partir de quarta-feira impossibilitarem a realização de todas as análises propostas em tempo hábil, por limitações laboratoriais. Para a comparação estatística entre os resultados das segundas e terças-feiras e das 8 e 13 horas de cada um destes dias foi utilizado o gráfico de Shewhart. Estes são construídos plotando-se os valores da média (Lm), num gráfico delimitado por linhas horizontais, denominadas limites de controle inferior e superior (LCI e LCS), chamados também de limites de ação (HIRATA, 2002). As linhas de controle delimitam regiões que têm probabilidade de 99,7 \% de conter qualquer valor de DQO lida.

Cálculo dos limites de controle eq. (11) a (14):

$$
L m=M A
$$

Limites de controle da média (LCI e LCS):

$$
\begin{aligned}
& L C I=L m-A_{2} \times R \\
& L C S=L m+A_{2} \times R
\end{aligned}
$$

Amplitude de uma ocasião (R):

$$
R=x_{\text {maior }}-x_{\text {menor }}
$$

onde " $A_{2}$ " é um coeficiente tabelado em função do número de amostras (n) e " $x$ " os valores obtidos no levantamento.

Foi feita também a comparação das médias encontradas de DQO afluente e efluente entre segundas e terças-feiras, pela análise estatística através do teste $\mathrm{t}$ de Student.

Este teste é um método que permite decidir se a diferença observada entre as médias de duas amostras pode ser atribuída à causa sistemática, ou se pode ser considerada como efeito das flutuações devidas ao acaso (D'HAINAUT, 1997). 
Foram consideradas como diferenças significativas aquelas a partir de $90 \%$ $(\mathrm{p}=0,10)$, considerando que por ser uma ETE real, os dados coletados sofrem várias interferências fora de controle.

Estas análises foram feitas apenas na segunda etapa na pesquisa. 


\section{RESULTADOS E DISCUSSÃO}

\subsection{Vazão, TDH e velocidade ascensional}

Os resultados indicam que a bomba instalada pode não corresponder à especificada em projeto, visto que esta deveria ter capacidade máxima de recalque de $16 \mathrm{~L} / \mathrm{s}$ e foram aferidas vazões de $40 \mathrm{~L} / \mathrm{s}$ durante picos de um minuto de duração. Observou-se que para períodos de maior vazão ao longo do dia a vazão máxima no UASB deveria ser de $4 \mathrm{~L} / \mathrm{s}$ (lâmina de $7 \mathrm{~cm}$ no vertedor), para que a unidade subseqüente (BAS) não sofresse extravasamento. Pois, nestes momentos notava-se que o tempo para que o nível de esgoto nas caixas distribuidoras de vazão do BAS abaixasse era maior do que o intervalo de um novo acionamento da bomba, fazendo com que ocorresse extravasamento das caixas distribuidoras direto para as tulipas coletoras do efluente final. No entanto, a vazão de 4L/s é inferior à afluente a ETE. Sugere-se, então, a utilização do tanque pulmão como um tanque de equalização, para que as vazões maiores que $4 \mathrm{~L} / \mathrm{s}$ não atinjam os reatores (considerando a utilização de metade do volume do reator UASB).

Ressalta-se que a estação elevatória instalada na ETE possui volume inferior ao especificado em projeto, o que ocasiona partidas da bomba em intervalos menores que os projetados, o que também contribuiu para o problema observado no BAS. Portanto, não se pode afirmar que o dimensionamento da bomba de recalque de $16 \mathrm{~L} / \mathrm{s}$ não seja adequado ao funcionamento dos reatores, mas sim, que, com o atual volume da 
elevatória, a bomba deveria ter menor capacidade de recalque. Os valores de vazão afluente aferidos na entrada do reator UASB, $480 \mathrm{~m}^{3} / \mathrm{dia}$ (Fase I) e $600 \mathrm{~m}^{3} / \mathrm{dia}$ (Fase II), não são compatíveis com os valores esperados para o início de plano $\left(300 \mathrm{~m}^{3} / \mathrm{dia}\right.$, segundo Kellner, 2003), e, na Fase II, estão próximos aos $700 \mathrm{~m}^{3} /$ dia esperados para o ano de 2023 (final de plano). Acredita-se que três fatores possam ter influenciado este aumento de vazão:

- Pode ter havido interferência do armazenamento de esgoto no tanque pulmão (capacidade de aproximadamente $300 \mathrm{~m}^{3}$ ), que, embora devesse funcionar apenas em caso de falta de energia, tem operado como um tanque de equalização inadequado. Com a elevatória possuindo menor volume do que o inicialmente projetado, sua cota de fundo na execução da obra ficou acima do nível da cota de fundo do tanque pulmão, fazendo com que esgoto fique armazenado neste, sendo necessária a abertura manual de um registro de fundo para permitir o retorno do esgoto.

- A vazão industrial afluente à ETE pode não estar corretamente quantificada ou atualizada;

- O procedimento de medida de vazão no vertedor é impreciso.

Vale chamar atenção para o fato de que, embora tenham sido usados os valores médios citados para cada fase, a vazão mostrou aumento gradativo do início ao fim da pesquisa sem causas aparentes.

Na Fase I a velocidade ascensional média foi de $0,94 \mathrm{~m} / \mathrm{h}$ e o TDH médio de 6 horas.

Antes do início da Fase II, foi instalado um by-pass na estação elevatória (EE), que pode ser visto na Figura 18, a fim de se ter maior controle da vazão, para que o inóculo não fosse carreado do sistema. A válvula verde que pode ser observada na figura 18 é a forma de regulagem da vazão a ser enviada para o reator UASB. Antes de iniciar-se a Fase II, foi feita uma calibração desta válvula relacionando sua abertura com a vazão afluente ao reator UASB. Esta válvula quando totalmente fechada permite que toda a vazão recalcada pela bomba chegue ao reator UASB. À medida em que é aberta, menos vazão chega ao reator, sendo esta retornada para a estação elevatória (como pode ser visto na Figura 19, nas indicações da tubulação de retorno). 


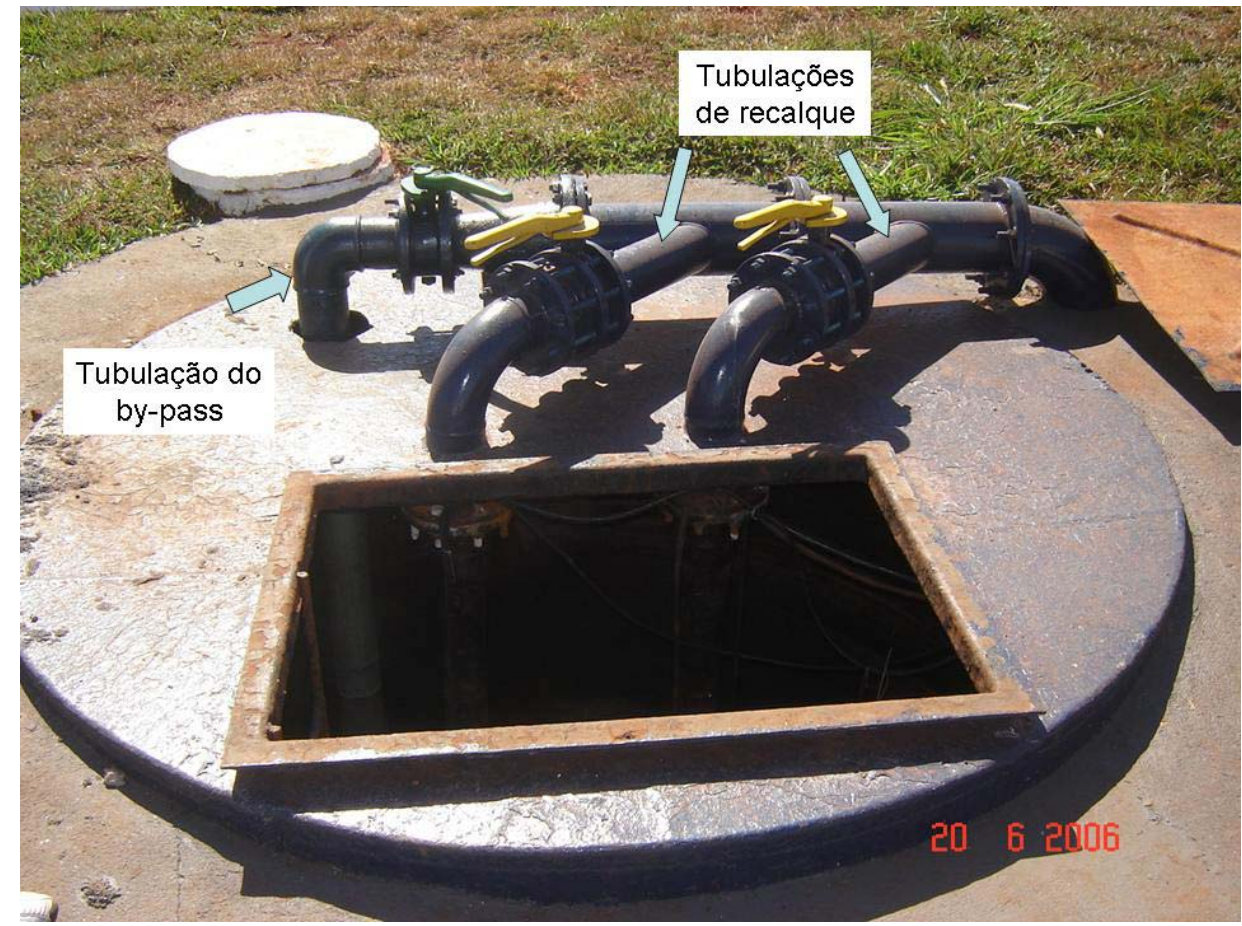

Figura 18 - Vista geral do by-pass instalado na estação elevatória.

A Figura 19a mostra a continuidade das tubulações de recalque e do by-pass, conectando vista externa e interna. Na Figura $19 \mathrm{~b}$ tem-se a vista interna da EE, onde se pode observar a vazão recalcada retornando pela tubulação do by-pass.

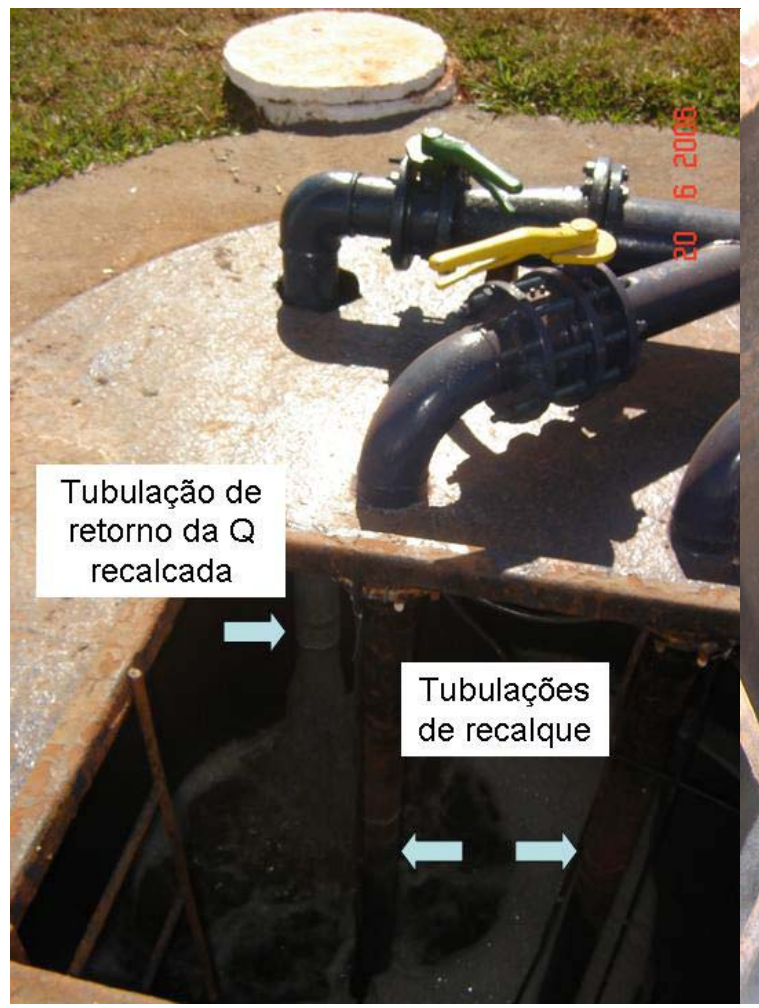

(a)

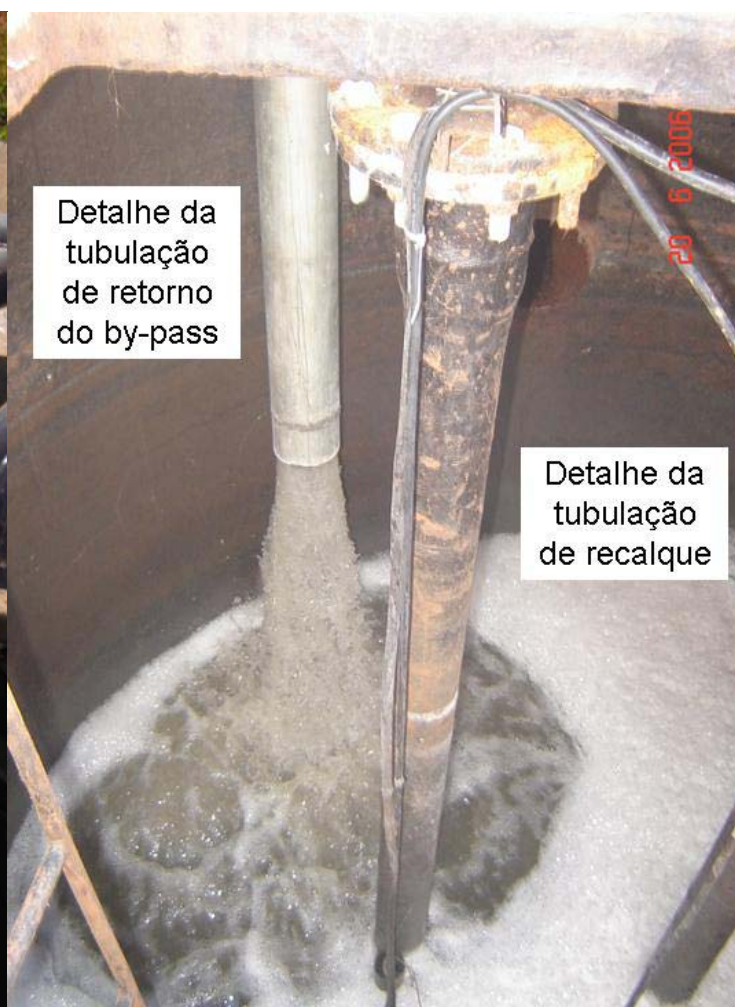

(b)

Figura 19 - Vista externa (a) e interna (b) da estação elevatória. 
Na Fase II, a velocidade ascensional média foi de $1,17 \mathrm{~m} / \mathrm{h}$ e o TDH médio de 5 horas. O by-pass se mostrou como boa alternativa de controle da vazão apenas por 30 dias (Figura 20). Após este período, a vazão apresentou-se excessiva novamente. Observou-se picos de $45 \mathrm{~L} / \mathrm{s}$, resultando em velocidades ascensionais de $7 \mathrm{~m} / \mathrm{h}$, valor extremamente elevado, visto que o valor para vazões máximas recomendado na literatura é de $1,5 \mathrm{~m} / \mathrm{h}$. Vale ressaltar que estes picos duravam no máximo 1 minuto, mas ocorriam todas as vezes que a bomba acionava, o que remeteu o reator à situação de estresse hidráulico novamente. Acredita-se que o mau funcionamento se deva a entupimentos, pois objetos grandes como embalagens plásticas podiam ser freqüentemente encontrados no UASB, mostrando também a insatisfatória eficiência do gradeamento e da caixa de areia quando submetida aos picos de vazão. A abertura completa da válvula do by-pass e seu posterior fechamento, como tentativa de desentupimento apresentou resultado satisfatório apenas duas vezes, lembrando que a cada vez que o by-pass era fechado a vazão total de recalque da bomba era encaminhada ao UASB, provocando altas velocidades ascensionais, como na situação original em que o by-pass não existia. A Figura 21 mostra um hidrograma com o by-pass possivelmente entupido. Nota-se nesta figura que o período das 8 horas às 13 horas, excepcionalmente, não teve vazão afluente. Este fato é devido à descarga semanal que a empresa TAM necessita promover para limpeza da rede sifonada que transporta seu efluente até a ETE. Este procedimento é feito com o armazenamento em um tanque, na empresa, do esgoto produzido por aproximadamente 4 horas e posterior descarte com a pressão acumulada no reservatório. Na Figura 22 está representado o hidrograma mais comumente observado, com picos elevados de pequena duração. 


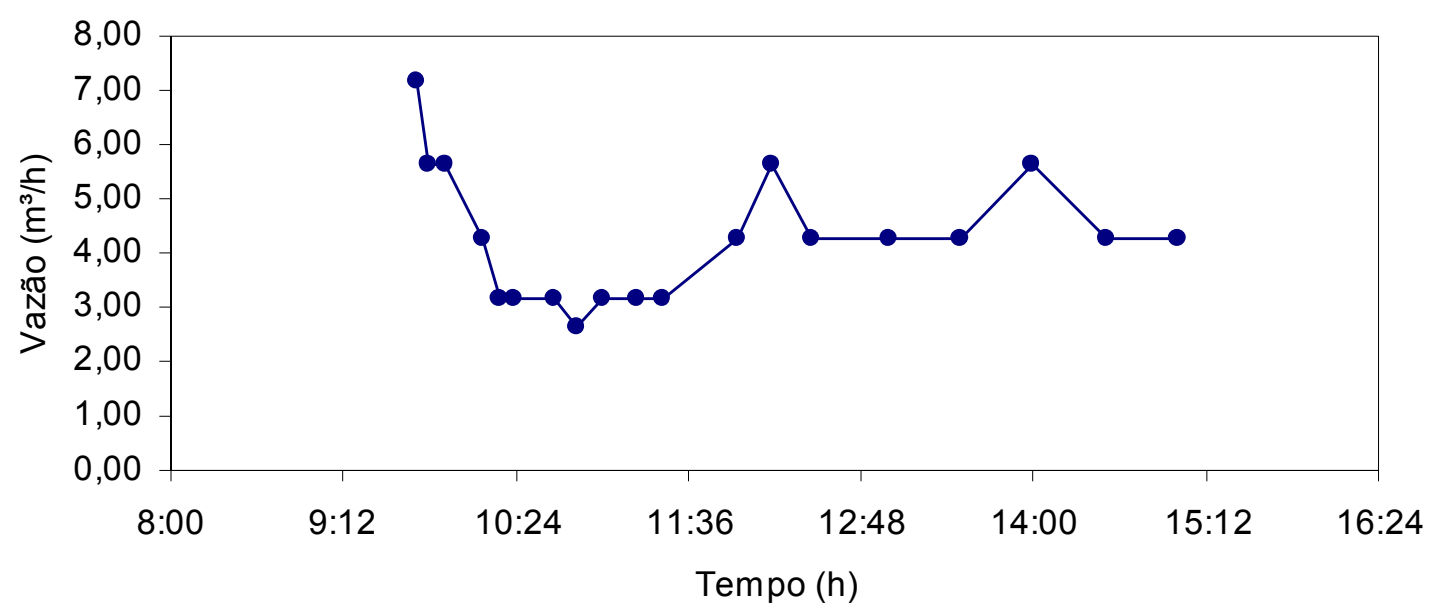

Figura 20 - Hidrograma de vazão do UASB em 13/07/2006 (156 dia de operação - Fase I), com bom funcionamento do by-pass.

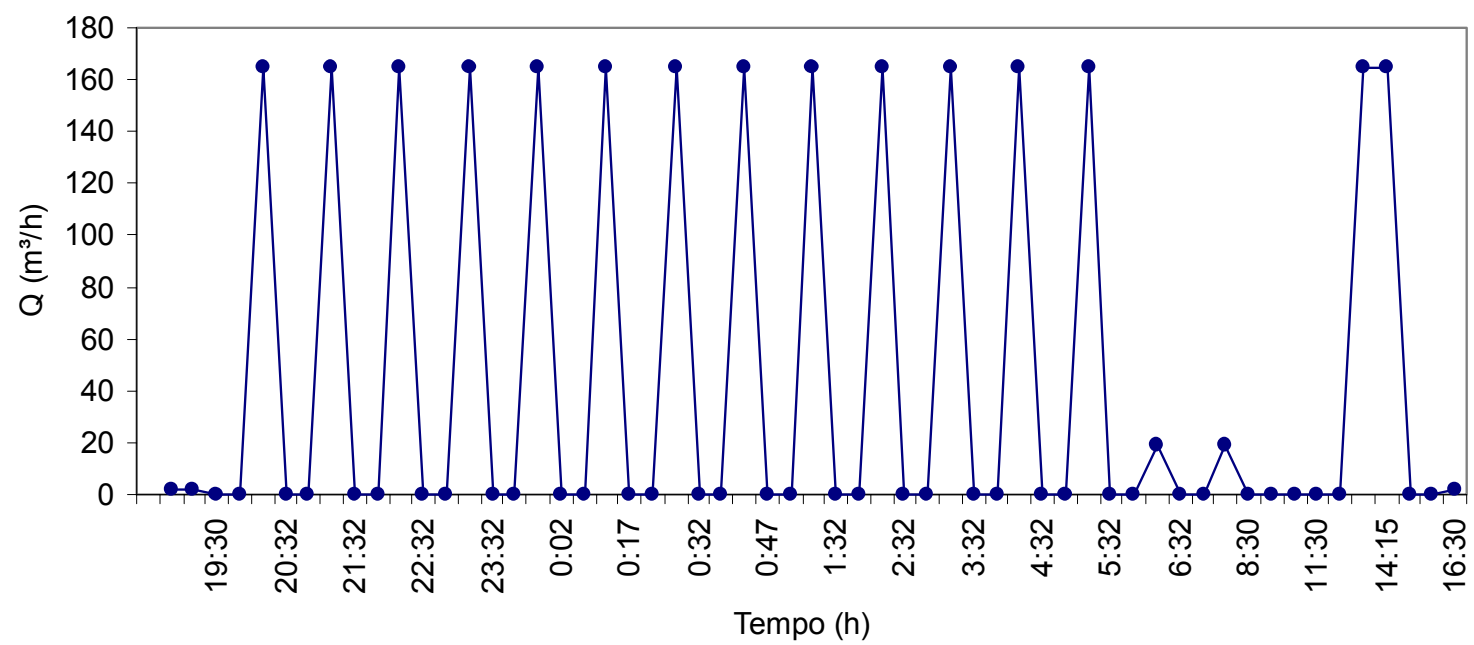

Figura 21 - Hidrograma de vazão do UASB em 15 e 16/08/2006 (190 dia de operação Fase II), com by-pass possivelmente entupido. 


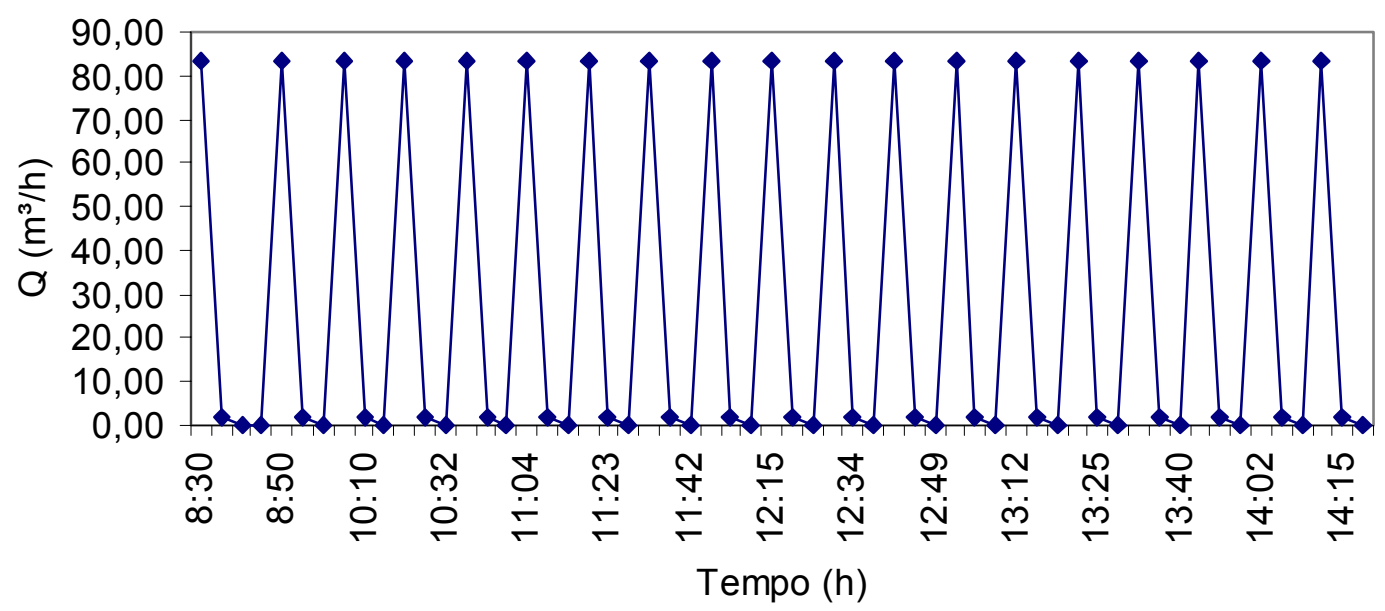

Figura 22 - Exemplo do hidrograma mais comumente observado na entrada do UASB com picos elevados de pequena duração, dia 211 de operação - Fase II (12/09/2006).

Comportamentos diferentes e inconstantes também foram observados e podem talvez ser atribuídos ao volume armazenado no tanque pulmão naquelas ocasiões. No dia 197 de operação (Figura 23) nota-se que a bomba era acionada a cada 30 minutos aproximadamente, no período das 9 horas às 13:30 horas. Após este período, a bomba era acionada por 2 minutos a cada 4 minutos, resultando em um hidrograma com características diferentes das comumente observadas. No hidrograma do dia 204 de operação (Figura 24) observa-se que para o período das 8:30 às 12:30 a bomba ligava por 2 minutos a cada 15 minutos; já no período de 12:30 às 13:30 funcionava por cerca de 20 minutos e desligava por 4 minutos. A partir das 14:30 funcionava por 42 minutos e permanecia desligada por 8 .

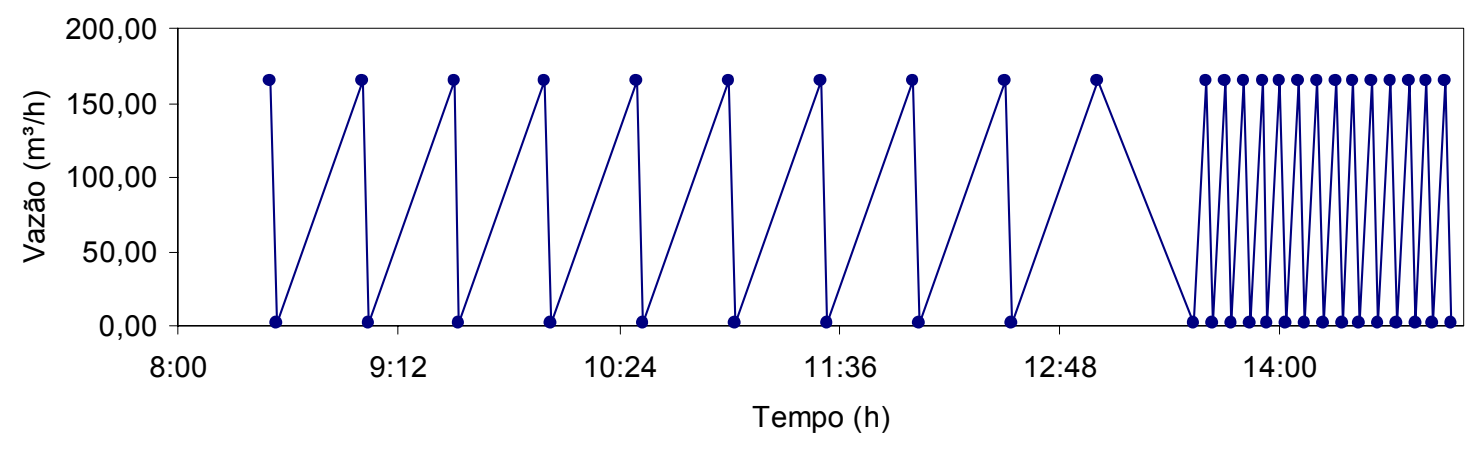

Figura 23 - Exemplo de hidrograma com comportamento diferente do mais comumente observado na entrada do UASB, dia 197 de operação - Fase II (22/08/2006). 


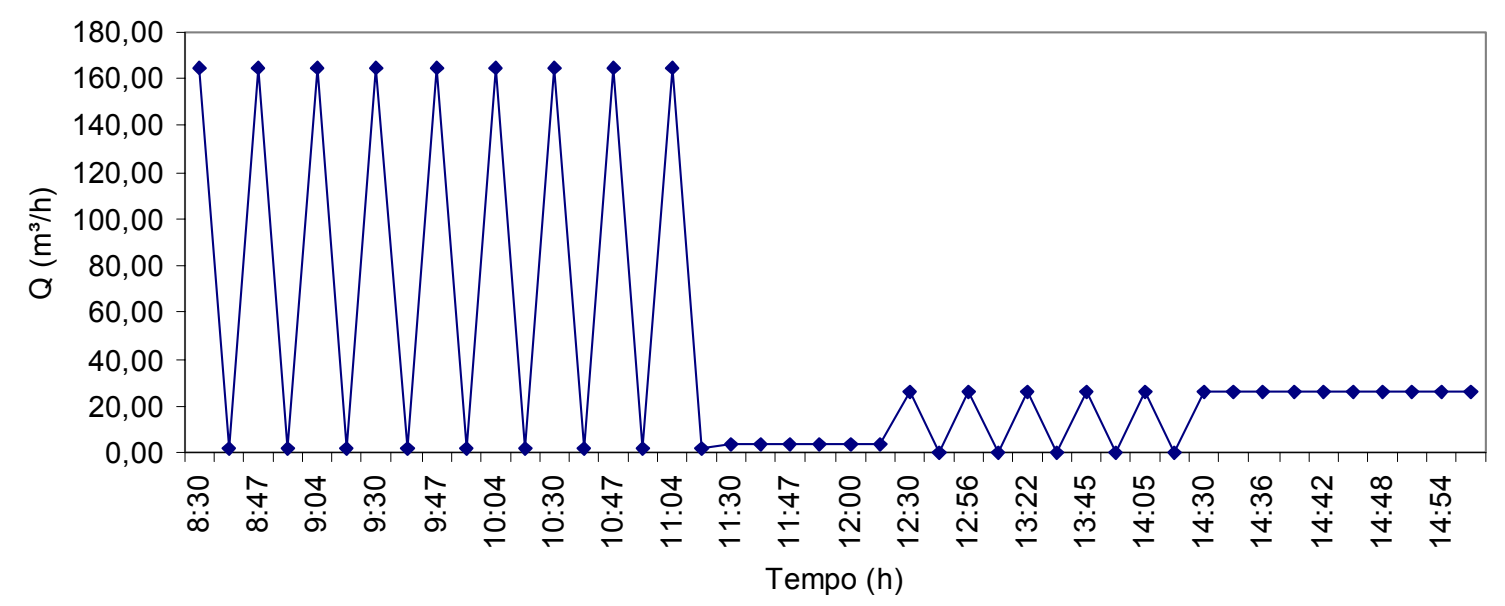

Figura 24 - Exemplo de hidrograma com comportamento diferente do mais comumente observado na entrada do UASB, dia 204 de operação - Fase II (04/09/2006).

\subsection{Teste de atividade metanogênica no inóculo e no lodo ao término do}

\section{experimento}

A atividade metanogênica específica do inóculo (coeficiente angular da reta) utilizando o acetato como substrato foi de $2,4 \mathrm{kgDQO} / \mathrm{kgSTV}$.dia, valor bastante superior à faixa normalmente encontrada de 0,2 a 0,4 kgDQO $/ \mathrm{kgSTV}$.dia, mostrando a excelente qualidade do lodo formado nos reatores UASB da ETE Flores de Rio Claro $\mathrm{SP}$, o que também foi verificado na análise de microscopia óptica. No anexo $\mathrm{C}$ podem ser observadas as quantidades de metano lidas, seu correspondente em litros, a quantidade em gramas de DQO consumida no teste e sua relação com a quantidade de SSV, para todos os testes realizados.

A Figura 25 mostra a produção de metano ao longo do teste de AME do inóculo utilizando acetato como substrato. 


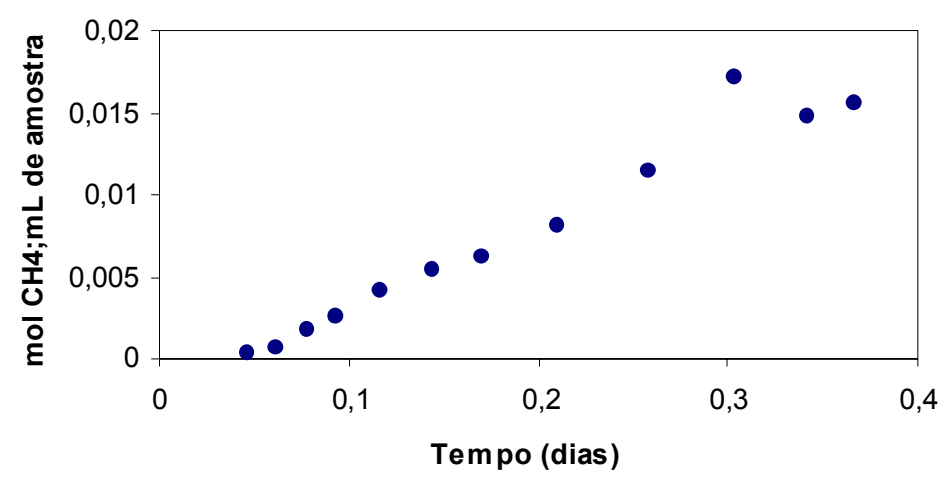

Figura 25 - Produção de metano ao longo do teste de AME do inóculo utilizando acetato como substrato.

A Figura 26 mostra o primeiro trecho retilíneo de inclinação máxima da curva com pontos ajustados por regressão linear e seu correspondente coeficiente angular.

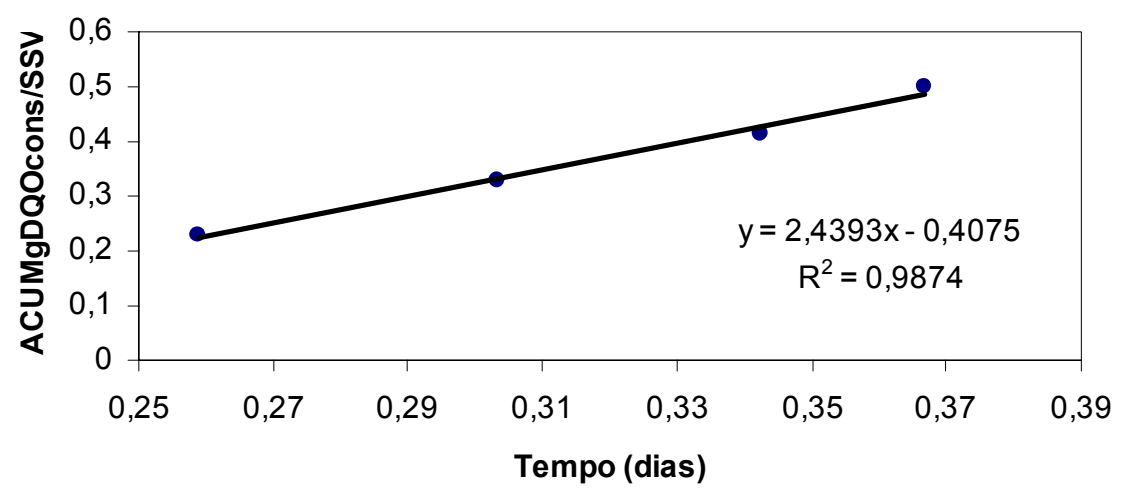

Figura 26 - Atividade metanogênica específica do inóculo, utilizando acetato como substrato.

Conhecido o valor da AME, foi calculada a quantidade necessária de inóculo, de acordo com o método descrito em Chernicharo (1997). Para o teste com acetato o valor encontrado foi $12 \mathrm{~m}^{3}$.

No teste utilizando como substrato o próprio esgoto da ETE Água Vermelha para se conhecer a atividade do lodo de inóculo com seu futuro substrato, a atividade obtida foi $60 \%$ inferior à do teste com acetato, resultando em uma quantidade necessária de inóculo de aproximadamente $30 \mathrm{~m}^{3}$, conforme se pode observar nas Figura 27 e 28.

A Figura 27 mostra a produção de metano ao longo do teste de AME utilizando esgoto como substrato. 


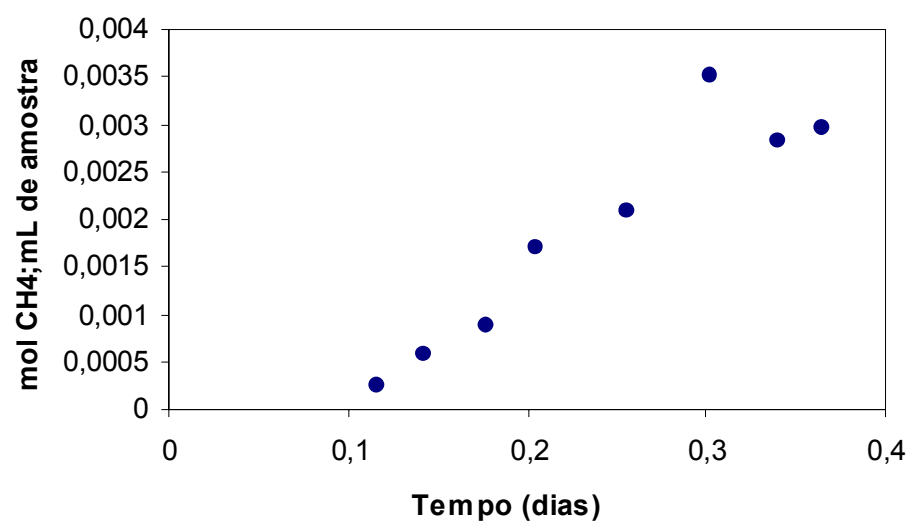

Figura 27 - Produção de metano ao longo do teste de AME do inóculo, com esgoto como substrato.

A Figura 28 mostra o primeiro trecho retilíneo de inclinação máxima da curva com pontos ajustados por regressão linear e seu correspondente coeficiente angular.

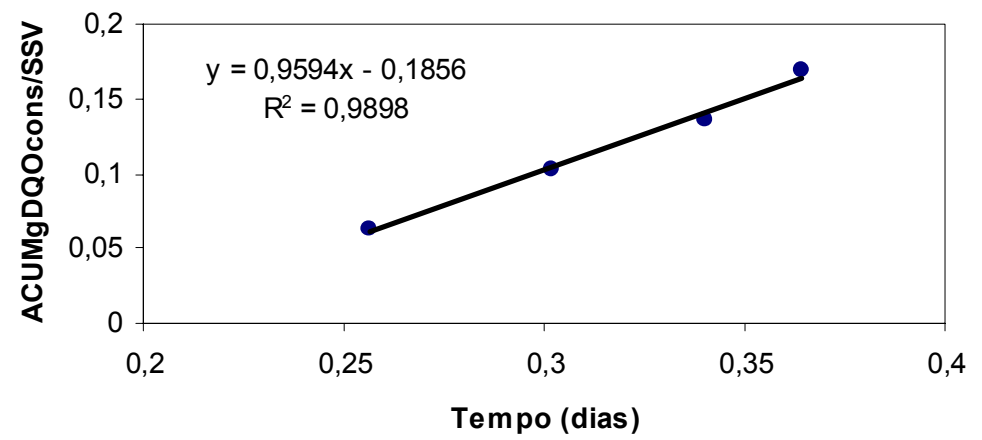

Figura 28 - Atividade metanogênica específica do inóculo, utilizando esgoto como substrato.

Mesmo com o próprio esgoto afluente à ETE como substrato, a atividade foi alta (0,96 kgDQO/kgSTV.dia). A quantidade de inóculo aplicada no reator foi de $12 \mathrm{~m}^{3}$, conforme o teste com acetato, frente aos custos envolvidos no transporte de $30 \mathrm{~m}^{3}$, que implicariam na necessidade de três viagens do caminhão disponível para este serviço até a cidade de Rio Claro - SP, a 70 km de distância.

È válida a observação de que a adoção de volume de lodo de inóculo correspondente a aproximadamente $10 \%$ do volume do reator, valor comumente adotado na prática, apresentou resultados melhores em relação a operação sem a adição deste.

No final do experimento, foi realizado teste de atividade metanogênica específica para o leito de lodo. Foi possível observar decréscimo da AME de 50 \% 
utilizando o substrato acetato $(1,1 \mathrm{kgDQO} / \mathrm{kgSTV}$.dia) em relação ao mesmo teste com o inóculo e de $30 \%$ usando o esgoto de Água Vermelha (0,6 kgDQO/kgSTV.dia). A Figura 29 mostra a atividade obtida utilizando esgoto como substrato e a Figura $30 \mathrm{com}$ o uso de acetato. Nota-se que o valor da atividade com o substrato esgoto foi mais próximo dos valores usualmente encontrados.

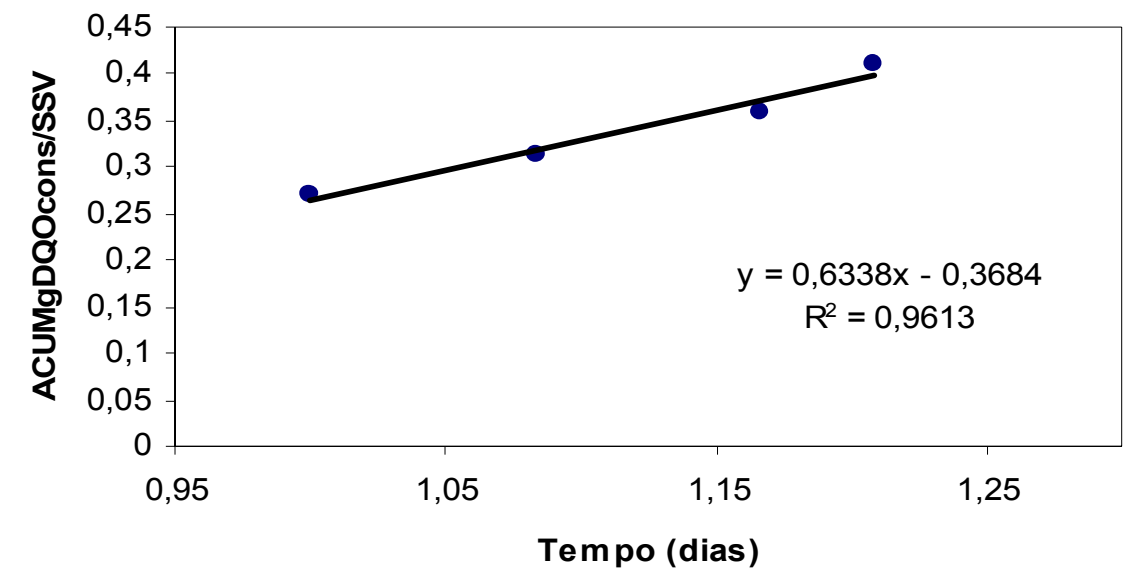

Figura 29 - Atividade metanogênica específica para o leito de lodo, no fim do experimento, utilizando esgoto como substrato.

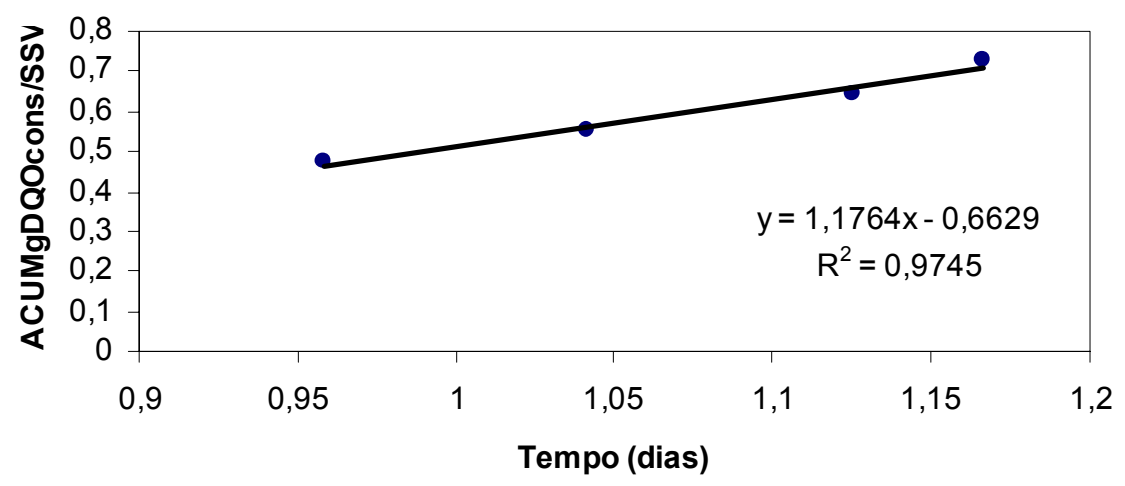

Figura 30 - Atividade metanogênica específica para o leito de lodo, no fim do experimento, utilizando acetato como substrato.

Apesar da redução da atividade observada, vale ressaltar que o lodo ainda possui boa atividade $(1,17 \mathrm{kgDQO} / \mathrm{kgSTV}$.dia para o acetato), mostrando seu potencial de tratamento cessadas as condições hidráulicas desfavoráveis. 


\subsection{Microscopia óptica no inóculo}

O exame microscópico mostrou a provável presença de Methanosaeta e Methanosarcina, o que justifica a excelente atividade metanogênica atingida. Todas as fotos estão com aumento de 1500 vezes.

A Figura 31 mostra a provável presença de Methanosarcina sp. em foto comum (a) e com fluorescência (b).

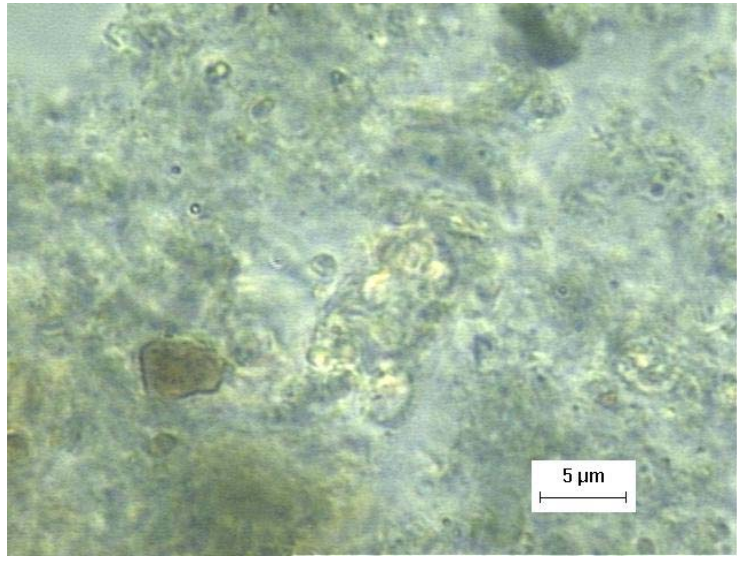

(a)

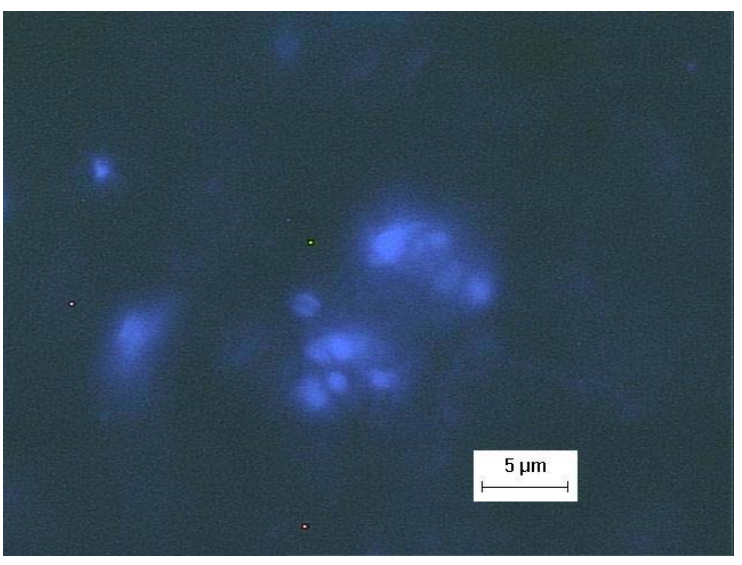

(b)

Figura 31 - Fotomicrografias de morfologias semelhantes Methanosarcina sp. em foto comum (a) e com fluorescência (b).

A Figura 32 mostra filamentos semelhantes a Methanosaeta sp.

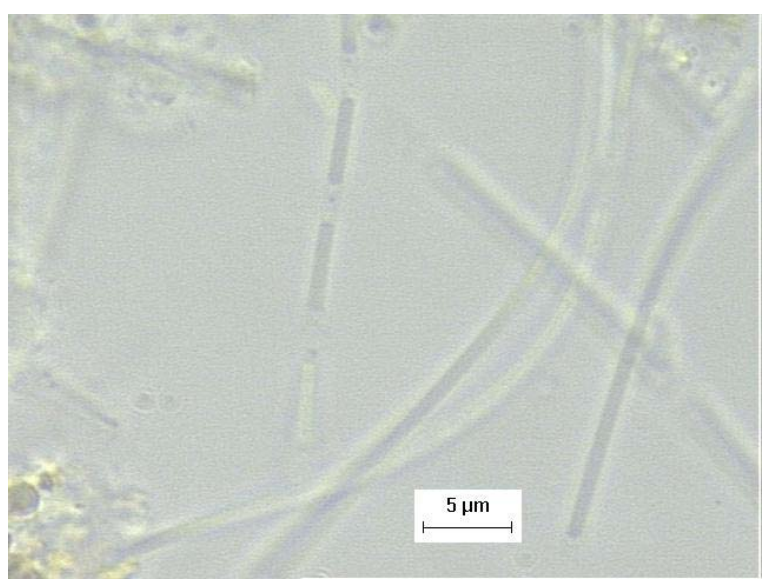

Figura 32 - Filamentos semelhantes à Methanosaeta sp.

As referências utilizadas para indicar a semelhança das morfologias nas microscopias foram Jenkins et al. (1993), Berk \& Son (1993), Black (2002) e Sakamoto et al. (2005). 


\subsection{Microscopia no $225^{\circ}$ e $280^{\circ}$ dia de operação}

No $225^{\circ}$ dia de operação, aproximadamente 60 dias após a inoculação, foi feita a microscopia óptica do leito de lodo (coletada a $0,25 \mathrm{~m}$ de altura). A visualização microscópica não mostrou a presença de morfologias semelhantes a Methanosarcina sp., que existiam no inóculo aplicado ao reator, como apresentado no item anterior. Visualizou-se apenas morfologias semelhantes a Methanosaeta sp. e bacilos. Este fato pode dever-se à baixa concentração de acetato, observada no afluente e efluente, mesmo em se tratando da partida do reator, situação que favorece a permanência das Methanosaeta em substituição às Methanosarcina. A Figura 33a mostra morfologias semelhantes a Methanosaeta sp. e bacilos e a Figura 33b feixes de morfologias semelhantes a Methanosaeta sp.

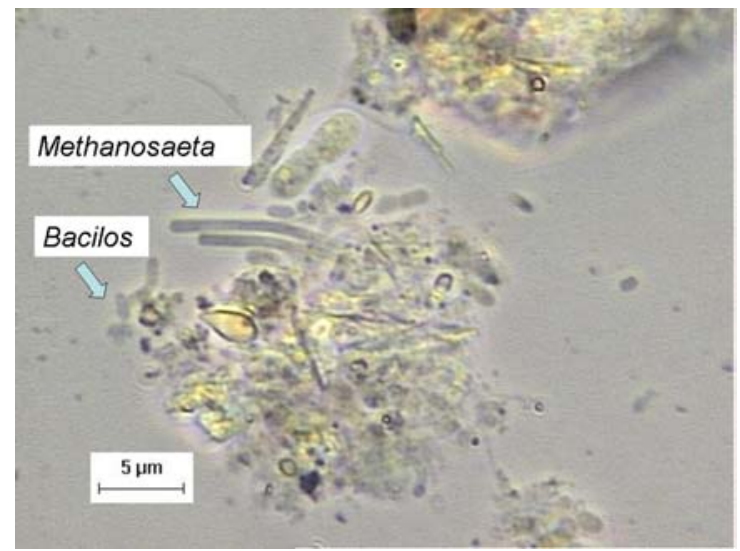

(a)

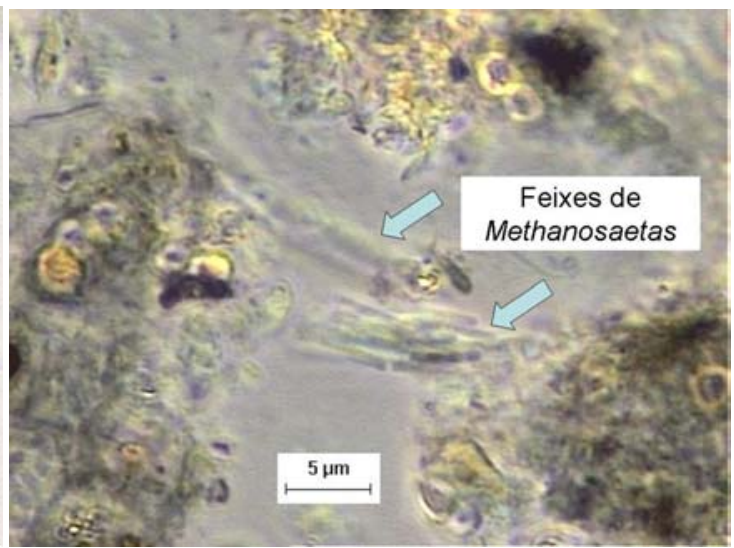

(b)

Figura 33 - Fotomicrografias de algumas morfologias presentes no reator no dia 225 de operação. Morfologias semelhantes a Methanosaeta e bacilos (a) e feixes de morfologias semelhantes a Methanosaeta (b).

No $280^{\circ}$ dia de operação foram realizadas as microscopias no leito de lodo $(0,25 \mathrm{~m})$ e na manta de lodo (coletada a $0,85 \mathrm{~m})$.

Nesta análise (Figura 34) foram visualizadas no leito de lodo, além das mesmas morfologias na análise anterior (Methanosaeta sp. e bacilos), cadeias de cocos. Observou-se também a presença de bacilos com inclusões, provavelmente grânulos de polifosfato, característicos de ambiente facultativo (Figura 35a). Os cocos encontrados também são semelhantes ao tipo que habita ambientes facultativos e podem ser 
observados em cadeia na Figura 35b. Este fato pode ser devido à permanência do afluente do UASB no tanque pulmão, antes de ser recalcado, onde se pode notar claramente também o desenvolvimento de algas (Figura 36), além do fato de haver mistura com o lodo aeróbio nesta região.

Na Figura 37 tem-se o reator UASB em início de processo de esvaziamento para procedimento de inoculação, onde se pode notar as algas procedentes do tanque pulmão. É válida também a observação nesta figura da corrosão na tulipa coletora do efluente final. Notou-se que nos horários em que o esgoto acumulado no tanque pulmão era recalcado para o UASB havia alteração de cor, passando a esverdeada tanto no afluente quanto no efluente, além de aumento de sólidos e DQO.
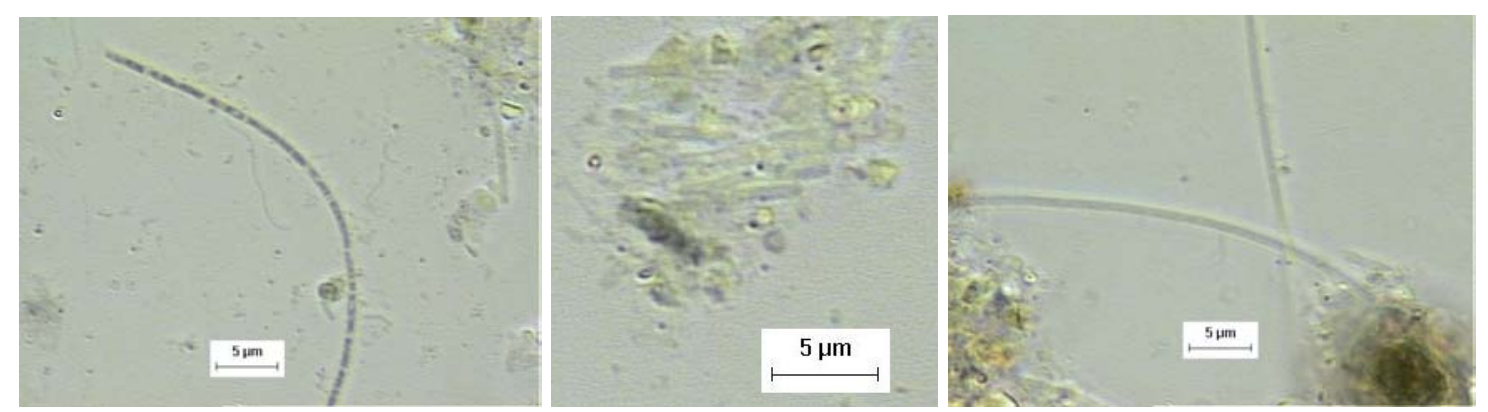

Figura 34 - Fotomicrografias de morfologias semelhantes a Methanosaeta sp.

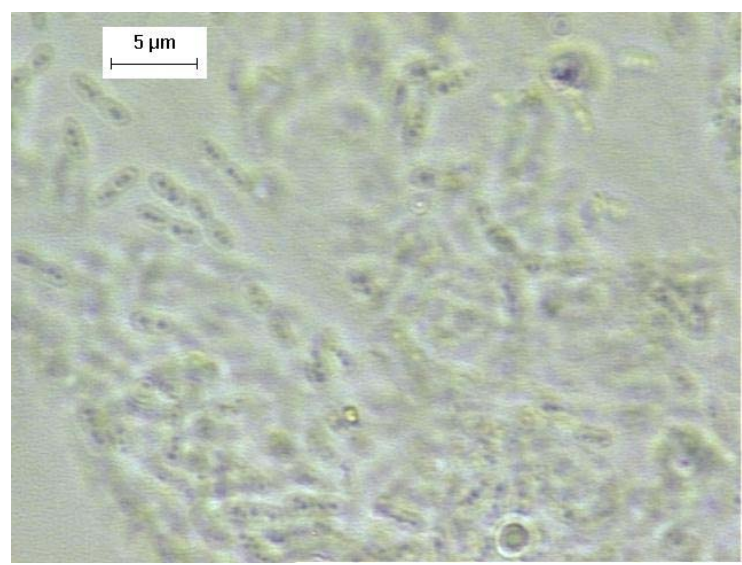

(a)

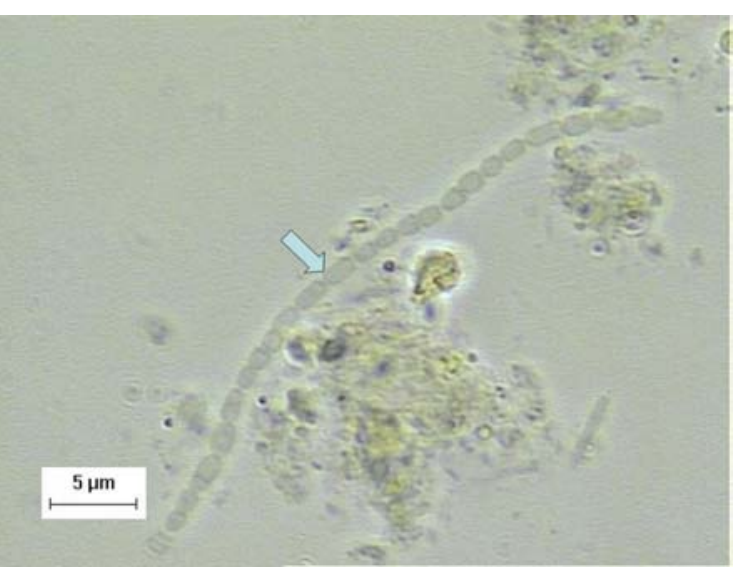

(b)

Figura 35 - Fotomicrografias de algumas morfologias presentes no leito de lodo no dia 280 de operação. Bacilos com inclusões (a) e cadeia de cocos (b). 


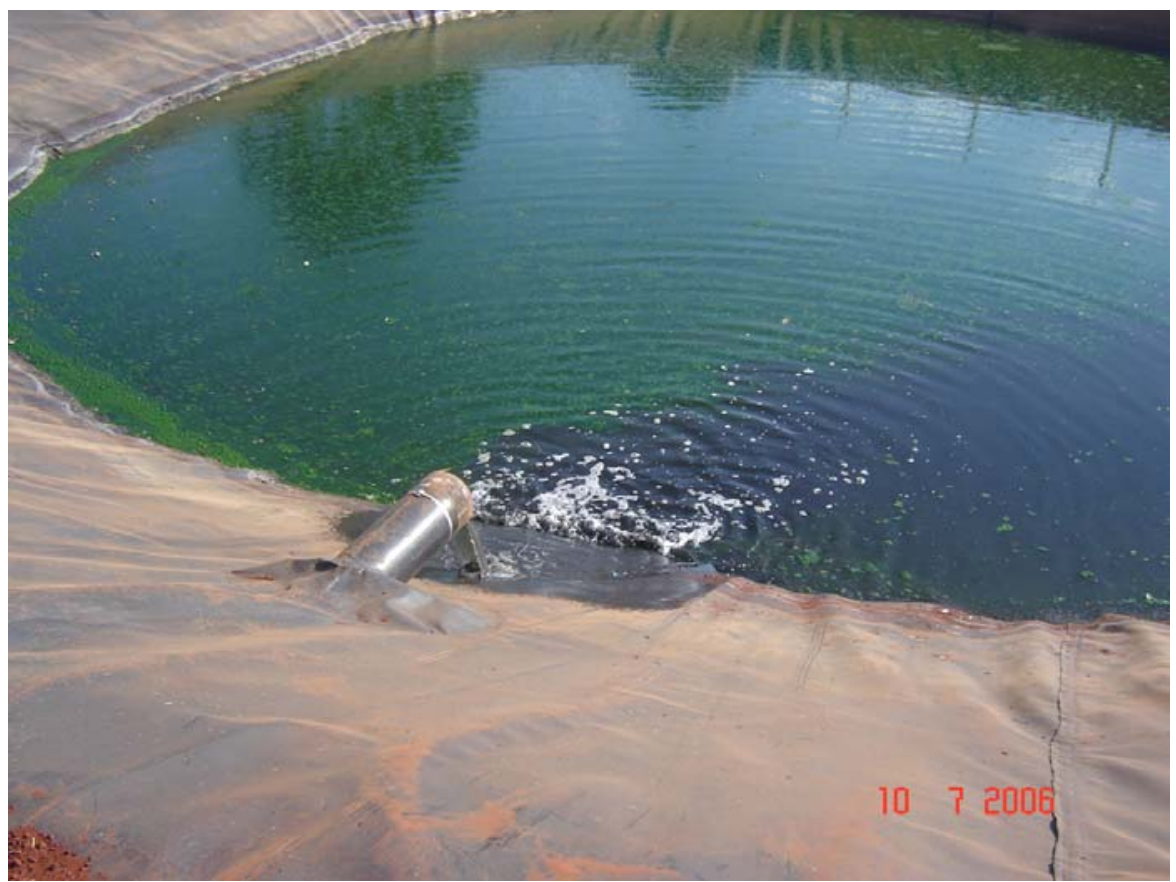

Figura 36 - Desenvolvimento de algas no tanque pulmão.

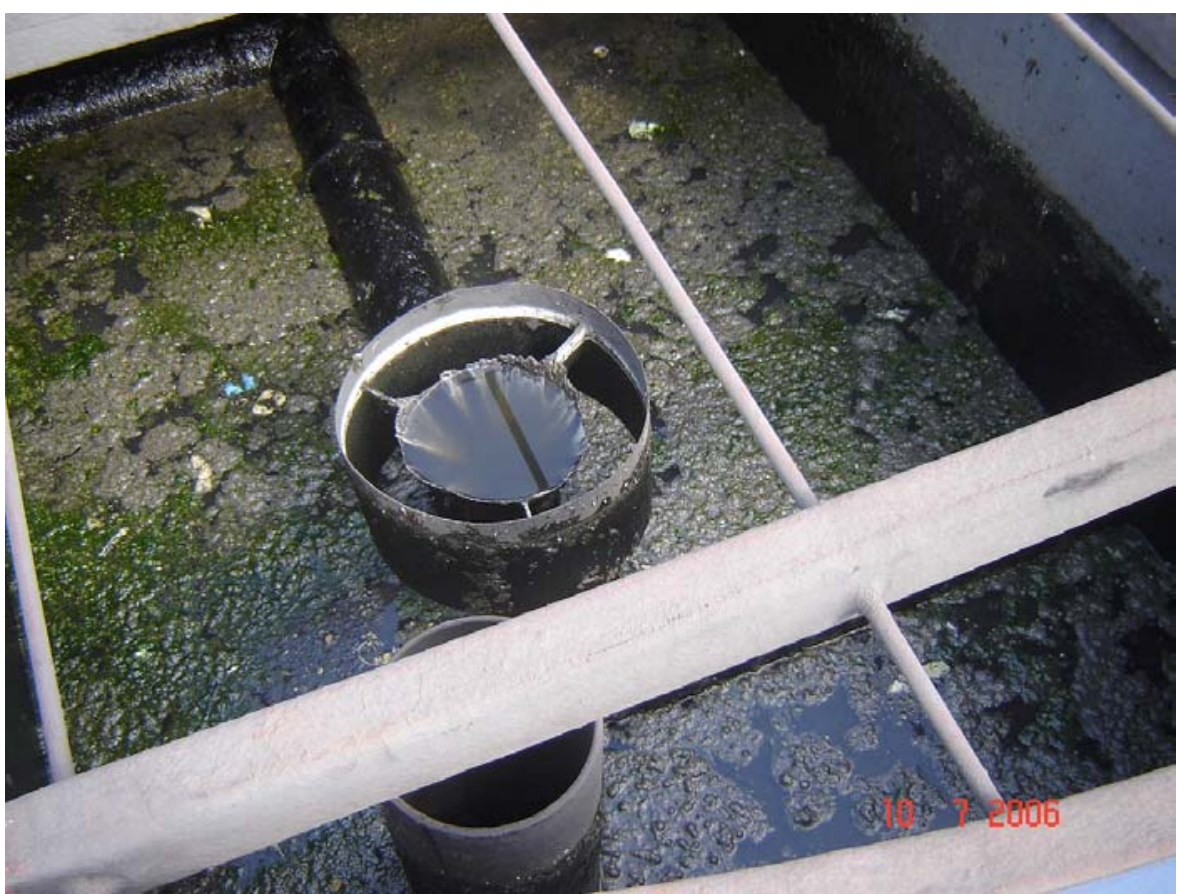

Figura 37 - Algas procedentes no tanque pulmão no reator UASB.

$\mathrm{Na}$ manta de lodo, na amostra coletada a $0,85 \mathrm{~m}$ de altura, observou-se a presença de bactérias semelhantes a fototróficas anoxigênicas (Figura 38a) e de morfologias semelhantes a Methanosaeta sp.(Figura 38b). 


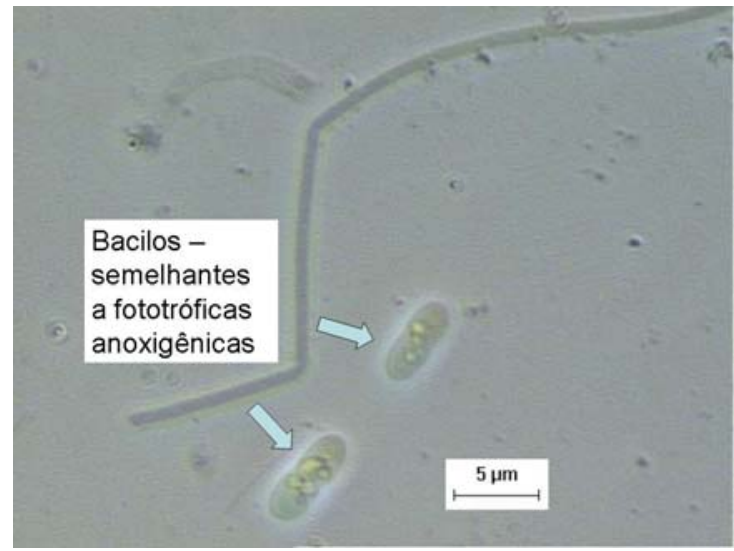

(a)

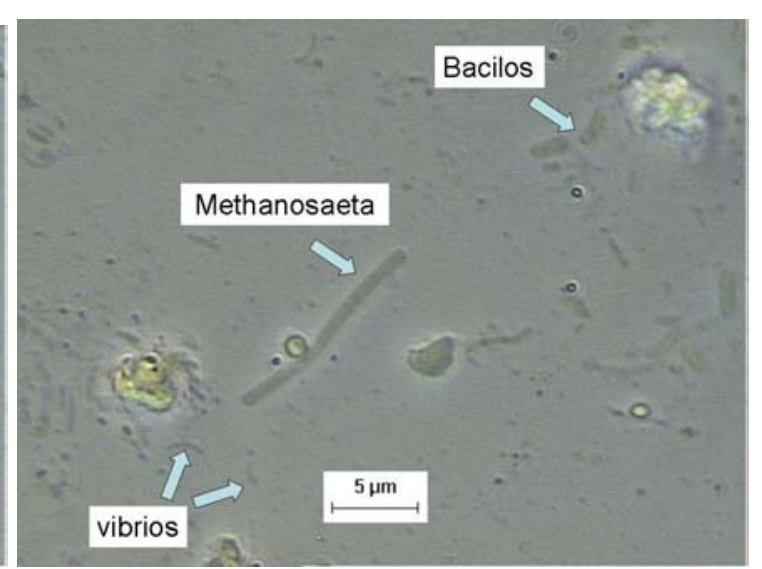

(b)

Figura 38 - Fotomicrografia de algumas morfologias presentes no leito de lodo $(0,85 \mathrm{~m})$ no dia 280 de operação. (a) Bacilos semelhantes a bactérias fototróficas anoxigênicas e morfologias semelhantes a Methanosaeta sp., bacilos e vibrios.

Notou-se que nesta altura do reator o lodo era disperso e a quantidade de microrganismos presentes era bastante inferior à amostra do leito. Estes dados diferem de Silva et al. (2005), onde a maior quantidade de biomassa metanogênica acetoclástica foi encontrada na altura de $0,75 \mathrm{~m}$ ao invés de $0,25 \mathrm{~m}$. Isto pode se dever ao protocolo adotado para o descarte do lodo do BAS ser diferente do sugerido em Sanevix (2003), e adotado pelo autor, de duas lavagens diárias do biofiltro. Na ETE Água Vermelha era feita apenas uma lavagem semanal, portanto, as possíveis interferências causadas pela entrada do lodo aeróbio tiveram impacto inferior ao da ETE UFES citado em Silva et al. (2005).

\subsection{Microscopia eletrônica de varredura (MEV)}

Com a amostra coletada no $225^{\circ}$ dia de operação, aproximadamente 60 dias após o início da Fase II, foi feita observação no microscópio eletrônico de varredura. Inicialmente, esperava-se realizar esta análise apenas se ocorresse a formação de grânulos, mas esta ocorrência não foi possível sob as condições ambientais fornecidas ao reator e as características do esgoto afluente, como já era esperado pelos relatos da literatura.

As imagens obtidas não acrescentaram novidades em relação à visualização pela microscopia óptica, já que não puderam ser observados arranjos de organismos. Apenas 
a presença de feixes de Methanosaeta sp.(Figura 39a) e a presença de bacilos (Figura 39b). Por este motivo não foi realizada esta análise ao término do experimento.

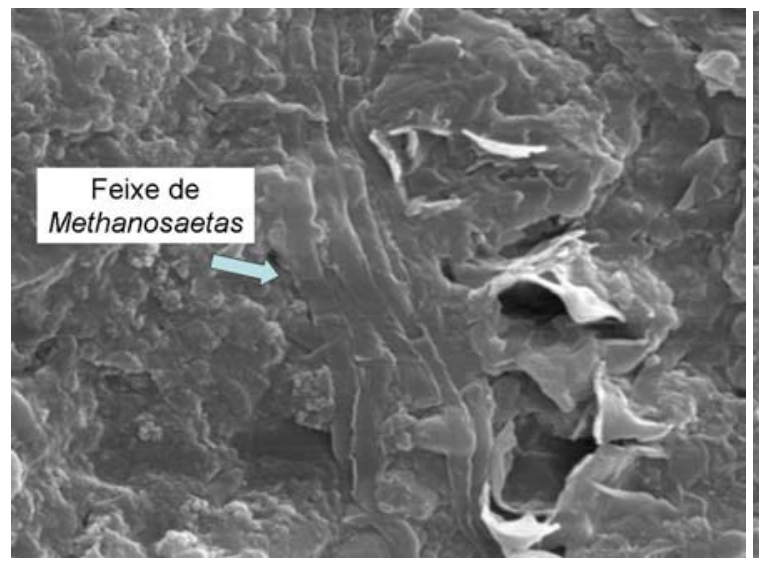

(a)

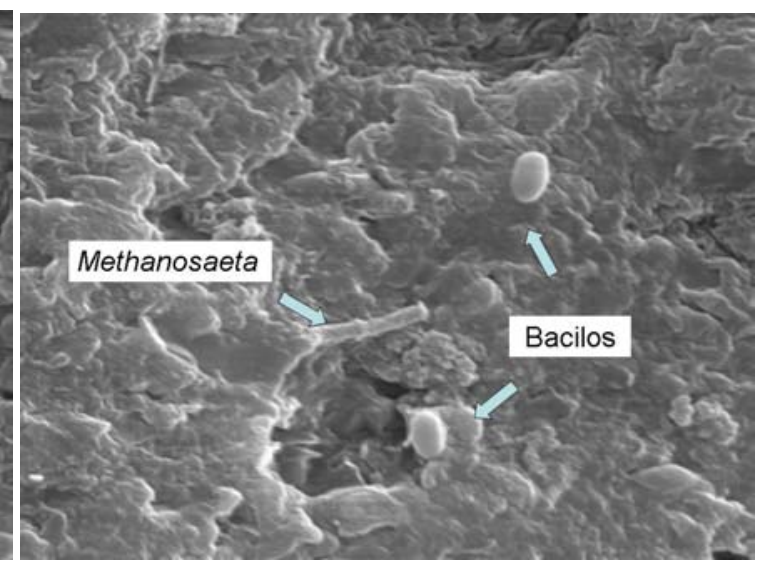

(b)

Figura 39 - Feixe de morfologias semelhantes a Methanosaeta sp. (a) e morfologias isoladas semelhantes a Methanosaeta sp. e bacilos (b).

\subsection{Demanda química de oxigênio (DQO)}

As médias de DQO afluente e efluente considerando todas as coletas compostas da Fase II, em todos os dias da semana, foram $600 \mathrm{mg} / \mathrm{L}$ e $400 \mathrm{mg} / \mathrm{L}$, respectivamente. $\mathrm{Na}$ análise estatística de segundas e terças-feiras os valores das médias foram próximos a esta média global, sendo $660 \mathrm{mg} / \mathrm{L}$ para o afluente e $360 \mathrm{mg} / \mathrm{L}$ para o efluente de segunda-feira, e $650 \mathrm{mg} / \mathrm{L}$ para o afluente e $410 \mathrm{mg} / \mathrm{L}$ para o efluente de terça-feira. $\mathrm{Na}$ Figura 40 se pode observar a variação da DQO bruta afluente nas segundas-feiras, entre 8 e 13 horas, em função dos dias de operação. "Lm" é a linha correspondente à média aritmética dos valores observados, "LCS" é o limite superior e "LCI" corresponde ao limite inferior. As tabelas com os dados de origem e a análise estatística encontram-se no anexo B. 


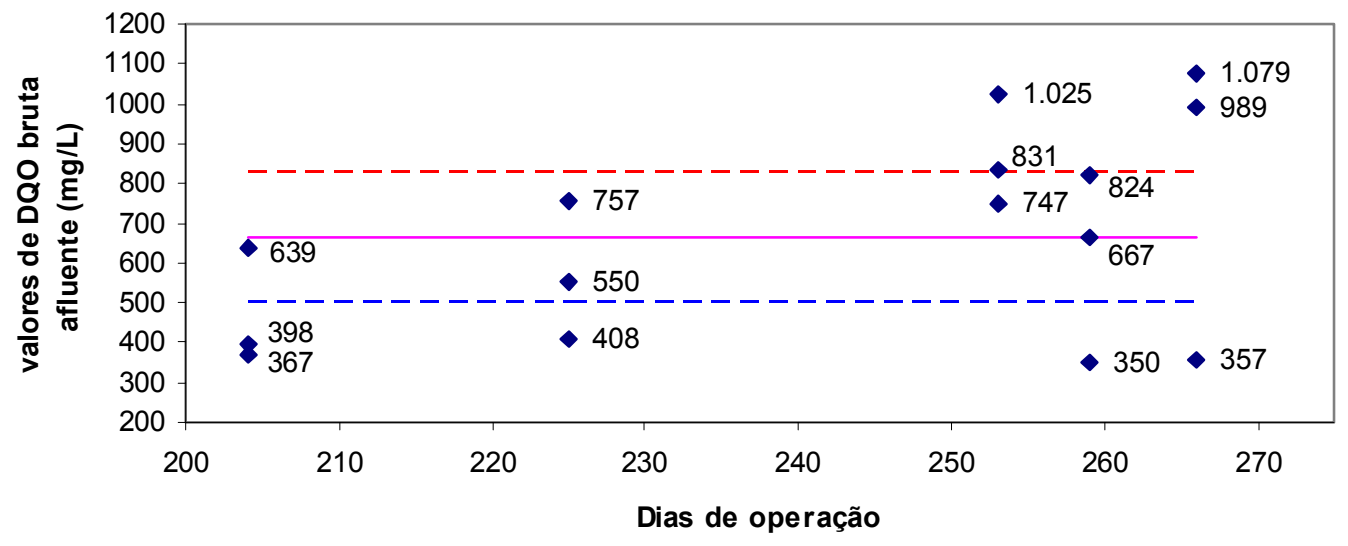

- DQOb Afluente (8 - 13 horas) $\longrightarrow$ Lm - - - LCS - - - LCl

Figura 40 - Comparação da DQO bruta afluente nas segundas-feiras, entre 8 e 13 horas, em função do dia de operação.

O valor médio da DQO bruta afluente nas segundas-feiras foi de $665 \mathrm{mg} / \mathrm{L}$ e o desvio padrão foi de $255 \mathrm{mg} / \mathrm{L}$. Pode observar na Figura 40 que $53 \%$ dos valores medidos encontram-se fora dos limites de controle, ou seja, o afluente apresenta grande variação ao longo do dia.

A Figura 41 mostra a variação da DQO bruta efluente nas segundas-feiras, entre 8 e 13 horas, em função dos dias de operação.

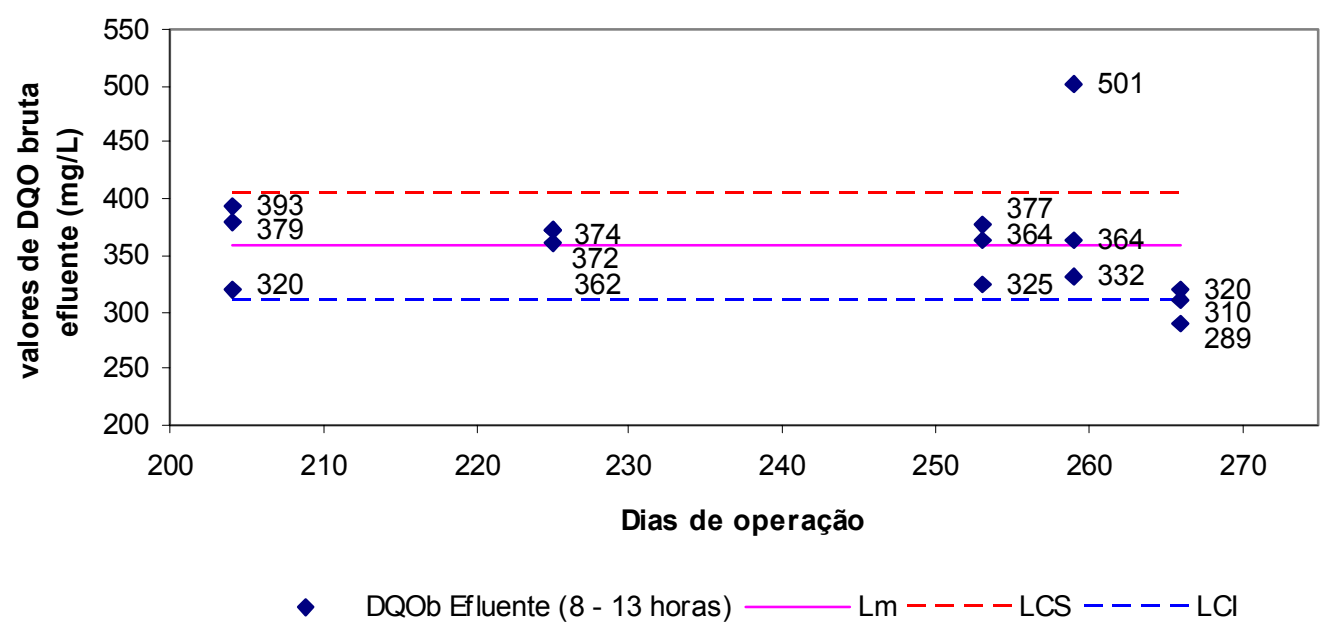

Figura 41 - Comparação da DQO bruta efluente nas segundas-feiras, entre 8 e 13 horas, em função do número de amostras.

O valor médio da DQO bruta efluente as segundas-feiras foi de $360 \mathrm{mg} / \mathrm{L}$ e o desvio padrão foi de $50 \mathrm{mg} / \mathrm{L}$. Pode-se inferir da Figura 41 que a variabilidade para o 
efluente foi menor que para o afluente, observando que apenas $20 \%$ dos valores encontrados estão fora dos limites de controle.

Para as terças-feiras, o valor médio da DQO bruta afluente foi de $650 \mathrm{mg} / \mathrm{L} \mathrm{e}$ para o efluente foi de $400 \mathrm{mg} / \mathrm{L}$. O desvio padrão na concentração afluente foi de $180 \mathrm{mg} / \mathrm{L}$ e no efluente de $72 \mathrm{mg} / \mathrm{L}$, como pode ser visto nas Figura 42 e 43. A variabilidade para o afluente nas terças-feiras foi aproximadamente igual à de segundafeira (50\%), enquanto que para o efluente de terça-feira a variabilidade de foi maior que a do efluente das segundas-feiras (42\%).

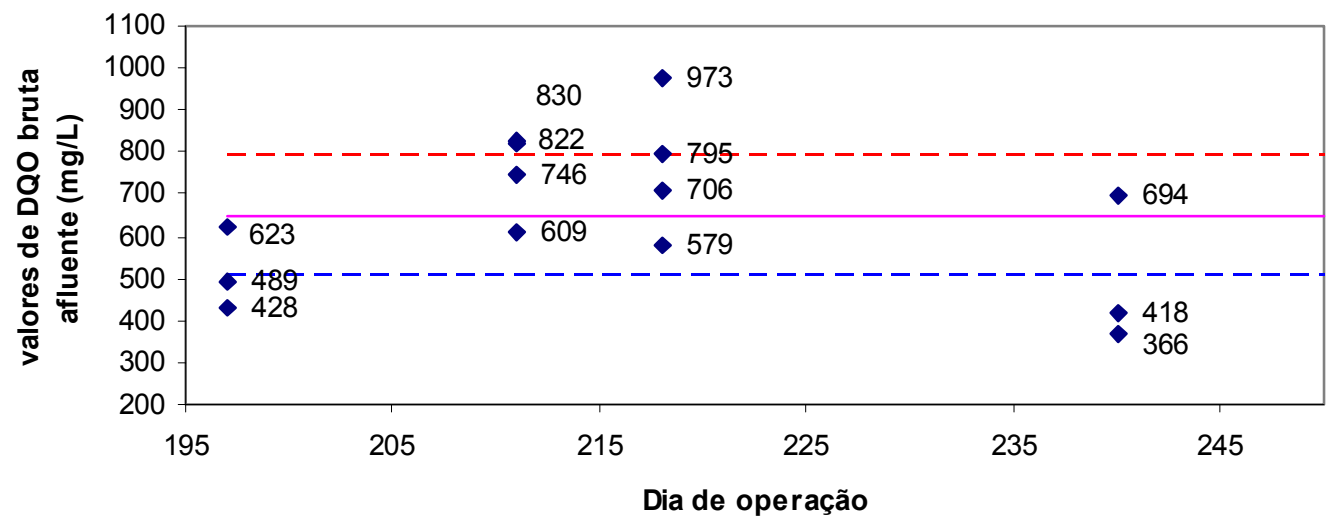

- DQOb Afluente (8 - 13 horas) Lm - - - LCS - - - - LCl

Figura 42 - Comparação da DQO bruta afluente nas terças-feiras, entre 8 e 13 horas, em função dos dias de operação.

\section{Avaliação dos valores de DQOb efluente entre 8 e 13 horas na} terça-feira

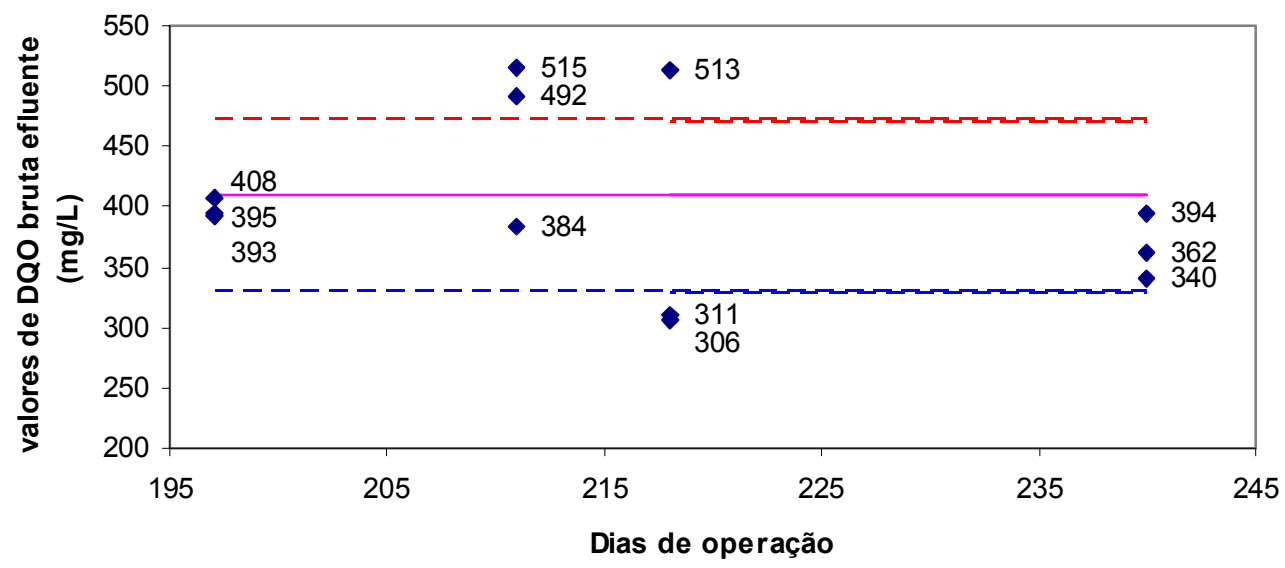

- DQOb Efluente (8 - 13 horas) L Lm - - - - Ls - - - Li

Figura 43 - Comparação da DQO bruta efluente nas terças-feiras, entre 8 e 13 horas, em função dos dias de operação. 
A análise comparando as amostras ao longo do dia pelo teste $\mathrm{t}$ de Student mostrou que não há diferença significativa entre segundas e terças-feiras para o afluente, como também foi visto pelos gráficos de Shewhart, pois o afluente teve o mesmo comportamento variável para os dois dias.

Para o efluente, o teste $\mathrm{t}$ mostrou diferença significativa (nível $\mathrm{p}=0,1$ ), o que também pode ser visto nos gráficos de Shewhart comparando as Figura 41 e 43.

A seguir são apresentados os gráficos resultantes da comparação entre segundas e terças-feiras (Figura 44 a 49), para afluente e efluente, separados em três períodos de horários. $\mathrm{O}$ primeiro das 8 às 10 horas, o segundo das 10 às 12 horas e o terceiro entre 12 e 13 horas. Os dias 204, 225, 253, 259 e 266 correspondem às segundas-feiras e os demais às terças-feiras.

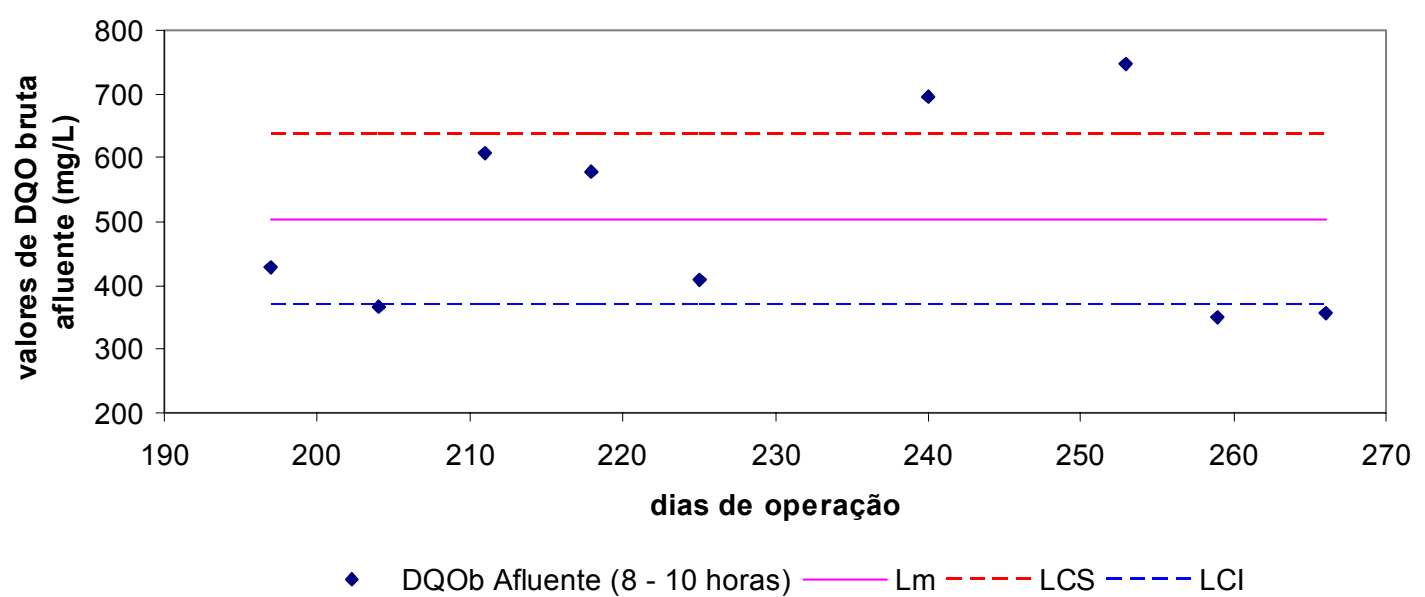

Figura 44 - Comparação da DQO bruta afluente, entre $2^{\mathrm{a}}$ e $3^{\mathrm{a}}$ feira, para o período das 8 às 10 horas. 


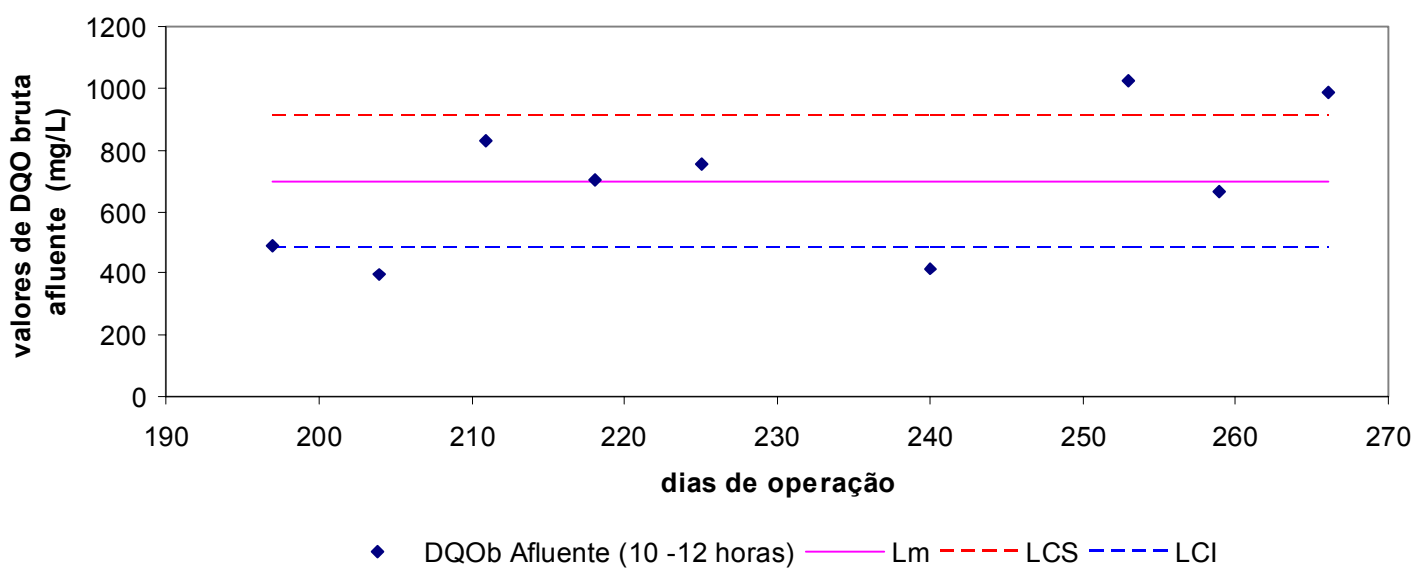

Figura 45 - Comparação da DQO bruta afluente, entre $2^{\mathrm{a}}$ e $3^{\mathrm{a}}$ feira, para o período das 10 às 12 horas.

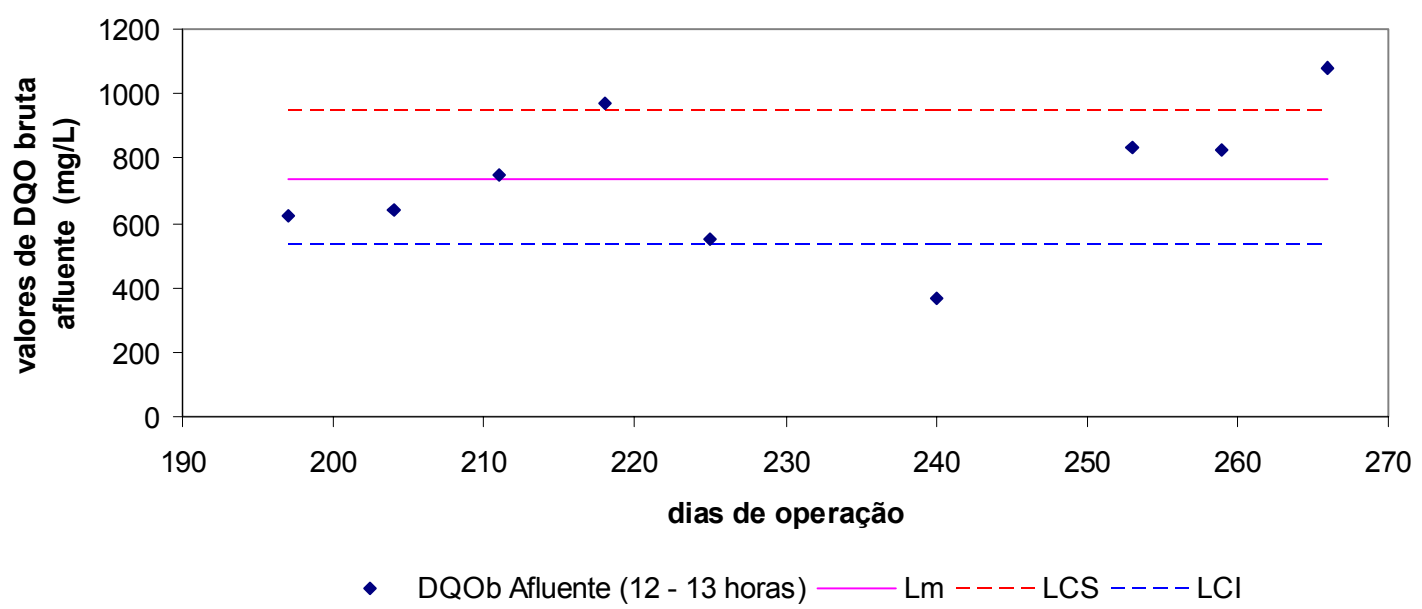

Figura 46 - Comparação da DQO bruta afluente, entre $2^{\mathrm{a}}$ e $3^{\mathrm{a}}$ feira, para o período das 12 às 13 horas.

Para o afluente, os períodos de 8 às 10 horas e de 10 às 12 horas apresentaram maior quantidade de pontos fora dos limites de controle, (44\%), enquanto que para o período de 12 às 13 horas essa quantidade foi de $33 \%$.

Para o efluente, o período das 10 às 12 horas foi o que mostrou maior quantidade de pontos fora dos limites de controle, $44 \%$. Para o período das 12 às 13 este valor foi de $22 \%$ e para o período das 8 às 10 a variabilidade foi menor, $10 \%$. 


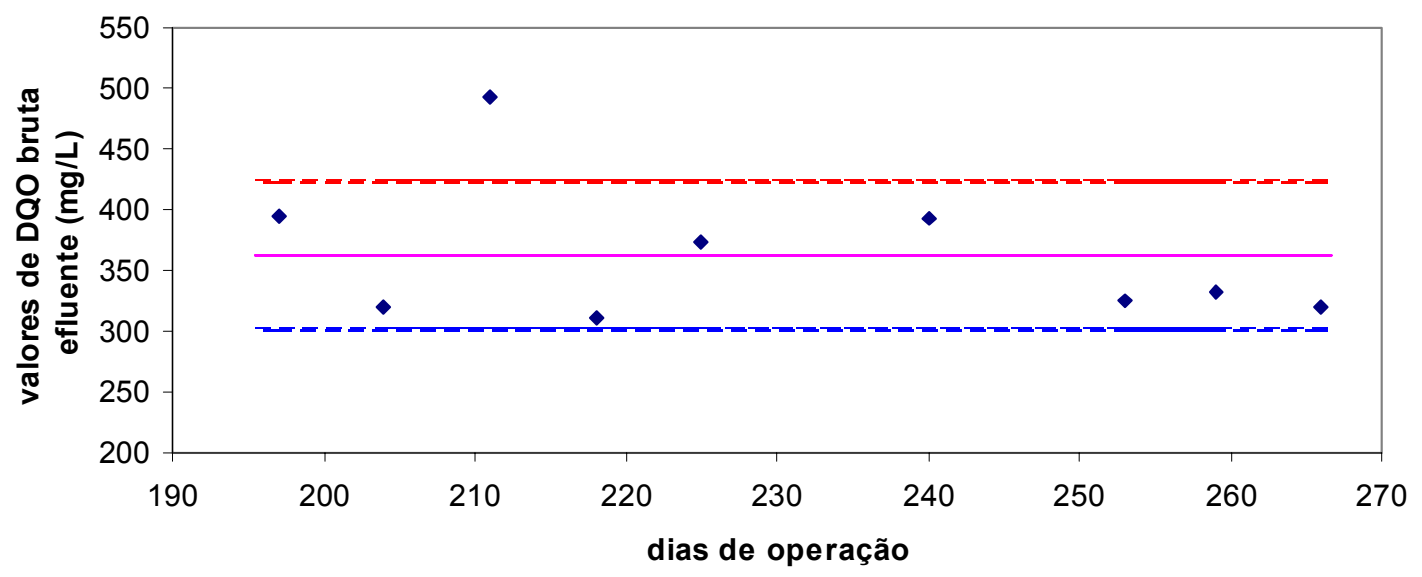

- DQOb Efluente (8 - 10 horas) $\longrightarrow$ Lm --- - LCS --- LCl

Figura 47 - Comparação da DQO bruta efluente, entre $2^{\mathrm{a}}$ e $3^{\mathrm{a}}$ feira, para o período das 8 às 10 horas.

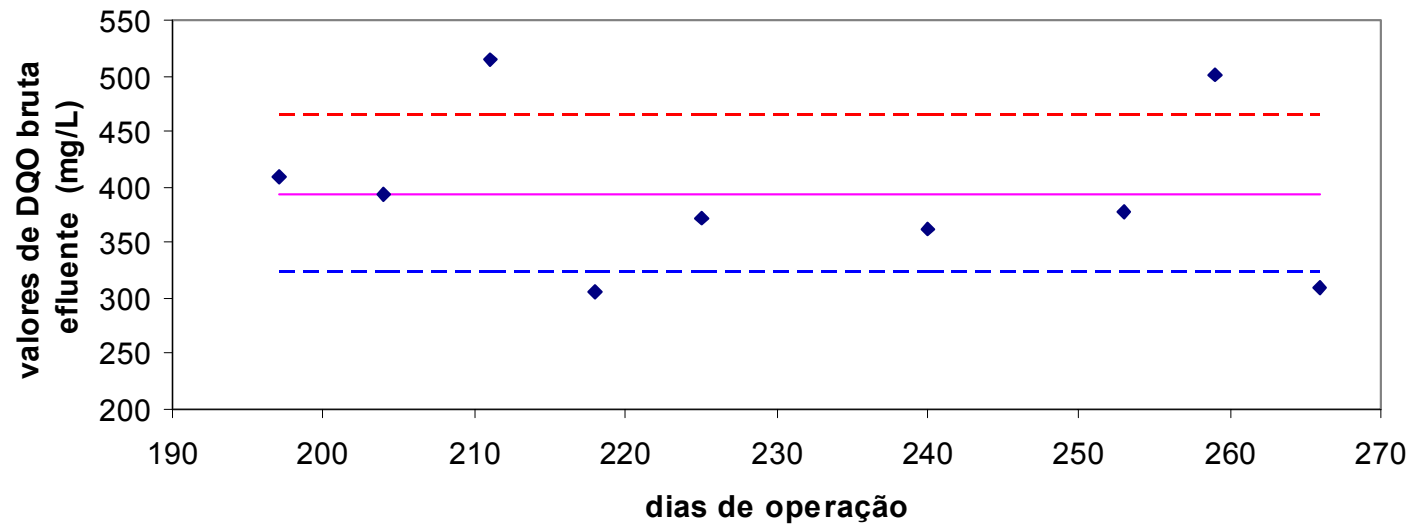

- DQOb Efluente (10-12 horas) — Lm - - - - LCS - - - - LCl

Figura 48 - Comparação da DQO bruta efluente, entre $2^{\mathrm{a}}$ e $3^{\mathrm{a}}$ feira, para o período das 10 às 12 horas. 


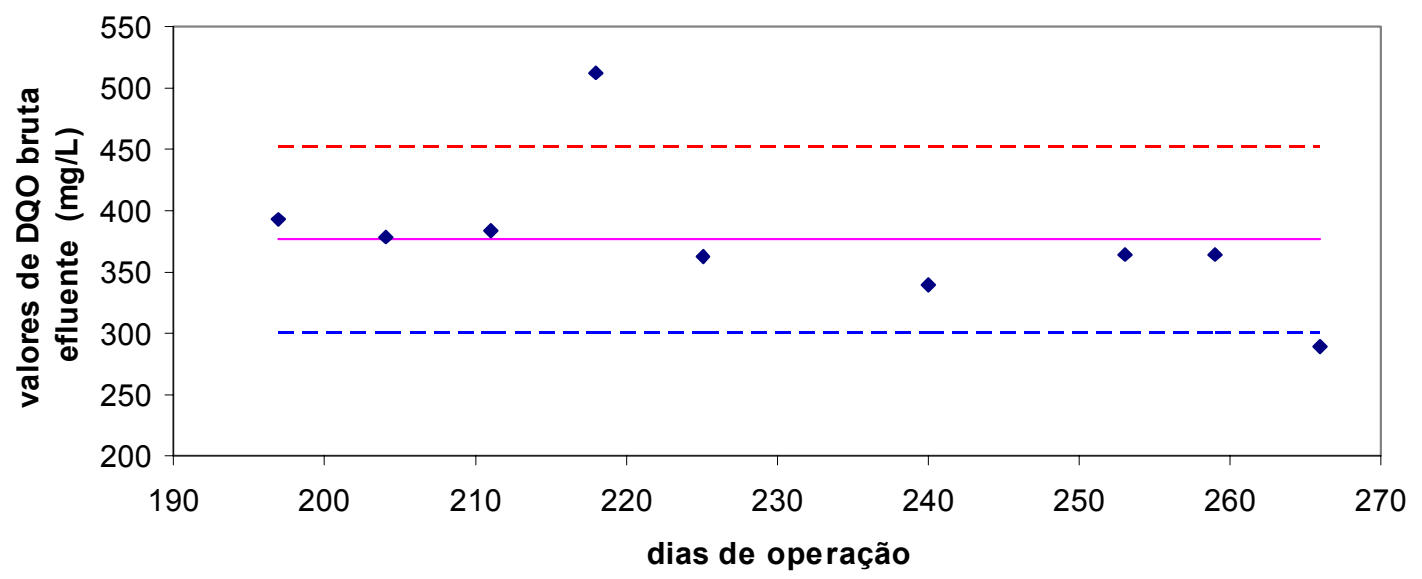

- DQOb Efluente (12 - 13 horas) — Lm --- - LCS - - - - LCl

Figura 49 - Comparação da DQO bruta efluente, entre $2^{\mathrm{a}}$ e $3^{\mathrm{a}}$ feira, para o período das 12 às 13 horas.

A Tabela 10 apresenta os valores médios da DQO, nos três períodos do dia observados e seus respectivos desvios-padrões.

Tabela 10 - Valores médios de DQO, nos três períodos do dia observados e seus respectivos desvios-padrões.

\begin{tabular}{llll}
\hline Horário & $\mathbf{8}$ às $\mathbf{1 0}$ & $\mathbf{1 0}$ às $\mathbf{1 2}$ & $\mathbf{1 2}$ às 13 \\
\hline Afluente & & & \\
DQO (mg/L) & 504 & 698 & 737 \\
$\begin{array}{l}\text { Desvio Padrão } \\
\text { Efluente }\end{array}$ & 154 & 231 & 219 \\
DQO (mg/L) & 362 & & \\
Desvio Padrão & 59 & 394 & 376 \\
\hline
\end{tabular}

As análises pelo teste $\mathrm{t}$ de Student com os dados de segundas e terças-feiras agrupados mostraram que;

Para o afluente:

- quando comparado o período de 8 às 10 horas com o de 10 às 12 horas, encontrou-se uma diferença significativa ao nível $\mathrm{p}=0,1$;

- para o período de 8 às 10 horas com o de 12 às 13 horas, encontrou-se diferença significativa ao nível $\mathrm{p}=0,02$;

- para o período de 10 às 12 com o de 12 às 13 horas, a diferença foi não significativa.

Isto indica que a DQO afluente no início da manhã é diferente da observada no restante do dia. Analisando-se os valores da tabela 10 (os valores de cada coleta podem 
ser observados nas tabelas B3 a B5 em anexo), conclui-se que a DQO no período das 8 às 10 horas é menor que a observada nos demais horários.

Para o efluente, quando comparados os pares de intervalos das 8 às $10 \mathrm{com}$ das 10 às 12 horas, 8 às 10 com 12 às 13 horas e 10 às 12 com 12 às 13 horas, a diferença entre as médias não foi significativa. Esse resultado é bastante importante, em termos de confiabilidade do processo, indicando que o reator consegue absorver as variações na composição do afluente sem prejuízo para o seu desempenho, não se mostrando sensível às sobrecargas orgânicas, quando analisados dados de dois dias da semana agrupados. Isto sugere que em uma avaliação global do tratamento, eficiência semanal ou mensal, por exemplo, não haveria diferença no efluente do reator UASB.

A Figura 50 apresenta a variação da DQO bruta afluente e efluente ao longo do tempo. Pode-se inferir desta figura que, na primeira fase, com DQO bruta afluente média de $400 \mathrm{mg} / \mathrm{L}$, houve eficiência média de $20 \%$ de remoção de DQO, com várias semanas de amostragem onde houve carreamento de matéria orgânica. Oliva (1997) obteve, durante a partida de UASB de $18 \mathrm{~m}^{3}$, sem inóculo, eficiência média de remoção de DQO de $45 \%$, com TDH de 16 horas, concluindo-se que a sobrecarga hidráulica afetou significativamente o desempenho do reator na remoção de DQO. Este fato foi também relatado por Oliva (1997), que observou aumento de DQO efluente nos ensaios que submetiam o reator UASB a sobrecargas hidráulicas. A autora concluiu refletir-se em um efeito pequeno, porém continuado, de desequilíbrio no processo de digestão.

Na Fase II, após três semanas da inoculação o reator começou a apresentar eficiência de $10 \%$ de remoção, com máxima eficiência de $60 \%$, com média de $40 \%$. Ressalte-se que a DQO bruta afluente média foi $30 \%$ maior em relação à Fase I $(600 \mathrm{mg} / \mathrm{L})$. Nota-se que a queda de eficiência no dia 259 é devida ao excesso de sólidos no reator, pois a manta estava com altura de aproximadamente $3 \mathrm{~m}$, quando foi então efetuado o descarte de $8,5 \mathrm{~m}^{3}$ de lodo. O reator começou a apresentar eficiência constante de remoção de DQO filtrada com 240 dias de operação (57 dias após a inoculação). Considerou-se esta data como possível início de estabilização, pois a DQO bruta apresentava remoção constante desde o $190^{\circ}$ dia e os valores de DBO bruta e filtrada apresentavam remoções a partir do dia 197. No entanto, os SDV começaram a apresentar remoção apenas no dia 266.

Os valores que originaram os gráficos dos parâmetros físico-químicos analisados encontram-se no anexo A. 
Pôde-se observar que os lançamentos de lodo de fossas (dias 211, 218 e 266) não provocaram eficiência negativa na remoção de DQO, como em Vieira et al. (2005), onde foram observados valores até 140 \% maiores no efluente em relação ao afluente na ocasião em que o reator UASB da ETE Lajes recebia até 10 caminhões com lodo de limpa-fossa por dia.

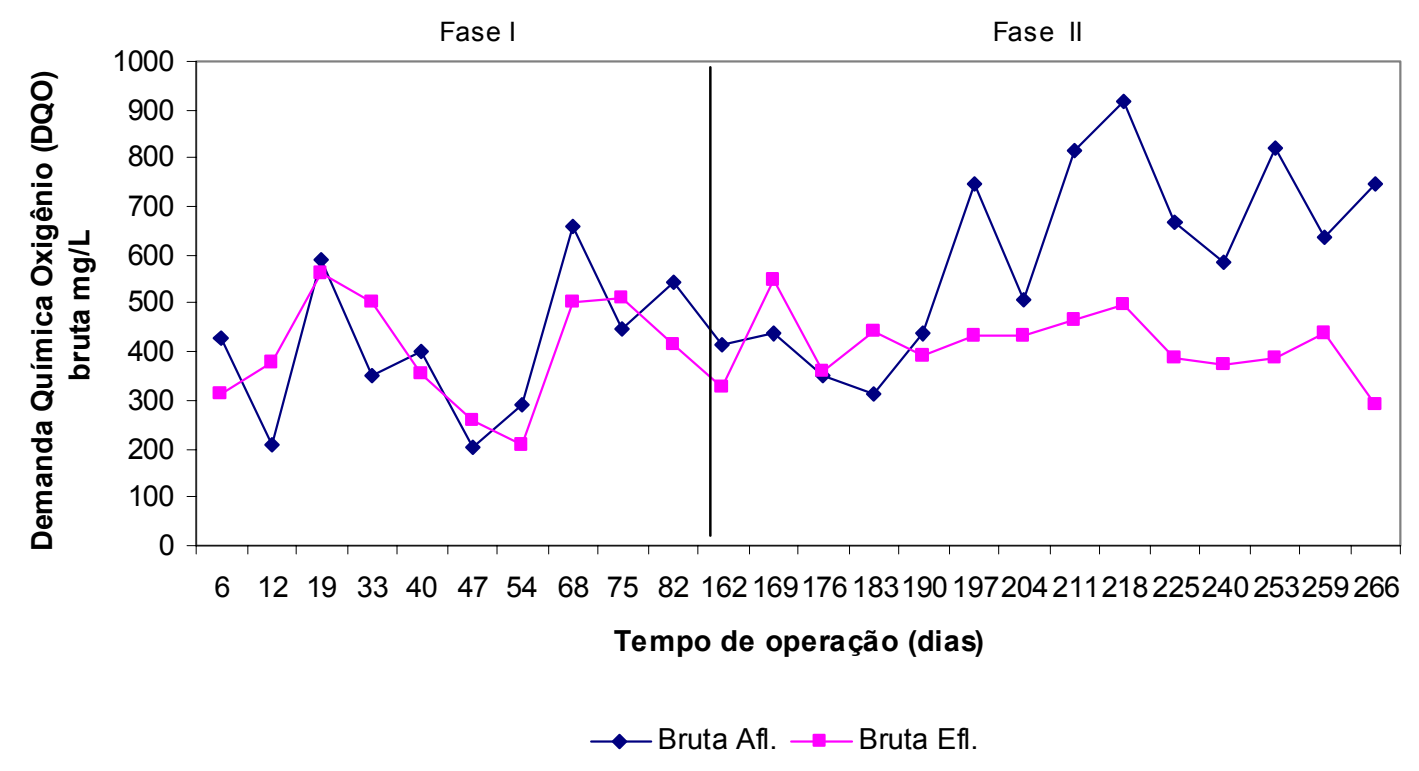

Figura 50 - Variação de DQO bruta afluente e efluente ao longo do tempo.

Na Fase I a média de DQO afluente filtrada foi $212 \mathrm{mg} / \mathrm{L}$, com eficiência média de remoção de $12 \%$, enquanto que na Fase II as médias foram de $274 \mathrm{mg} / \mathrm{L}$ e $24 \%$, com eficiência máxima de $51 \%$. A baixa eficiência pode estar relacionada à ocorrência de digestão incompleta no reator, onde a matéria orgânica em suspensão estava possivelmente sendo dissolvida, mas não convertida a metano e $\mathrm{CO}_{2}$, pois observou-se aumento de DQOf e SDT no efluente até o dia 240 de operação. Oliva (1997) também observou queda de eficiência de remoção de DQO quando o reator em estudo foi submetido a sobrecargas hidráulicas.

A fração filtrada da DQO representou em média $60 \%$ da DQO efluente, mostrando que a remoção física predominou sobre a biológica.

\subsection{Série de sólidos}

Da Figura 51 a Figura 56 se pode observar o comportamento da concentração de sólidos totais e suspensos, afluentes e efluentes, ao longo do tempo. A remoção de 
sólidos totais começou a ocorrer a partir do dia 197 de operação, com eficiência média de $35 \%$ e máxima de $81 \%$. Os valores de pico observados na Figura 51, nos dias 211, 218 e 266, correspondem a lançamentos indevidos de lodo de limpa-fossas, que ocorrem de forma esporádica sem aviso prévio. Estes picos devem-se aos sólidos dissolvidos fixos (SDF) que correspondem a aproximadamente $90 \%$ dos sólidos totais fixos (STF).

Pode-se observar na Figura 51 que os lançamentos de lodo de fossas provocaram eficiência negativa na remoção de sólidos totais, como em Vieira et al. (2005). Sobrepostos aos dados de ST estão os dados de DQO de amostras não filtradas, onde se pode observar que o lançamento de lodo não provocou alteração na remoção de DQO.

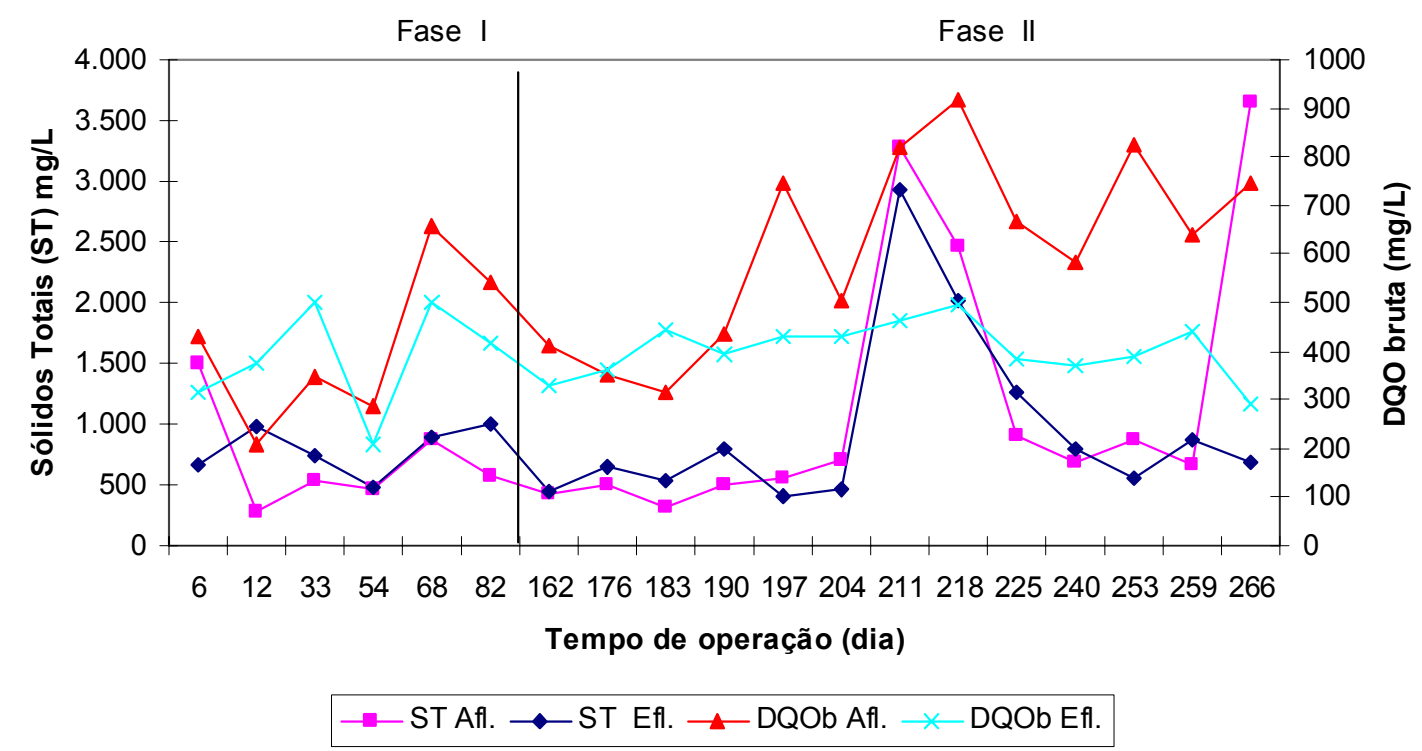

Figura 51 - Variação da concentração de sólidos totais e DQO bruta afluente e efluente. 
Fase I

Fase II

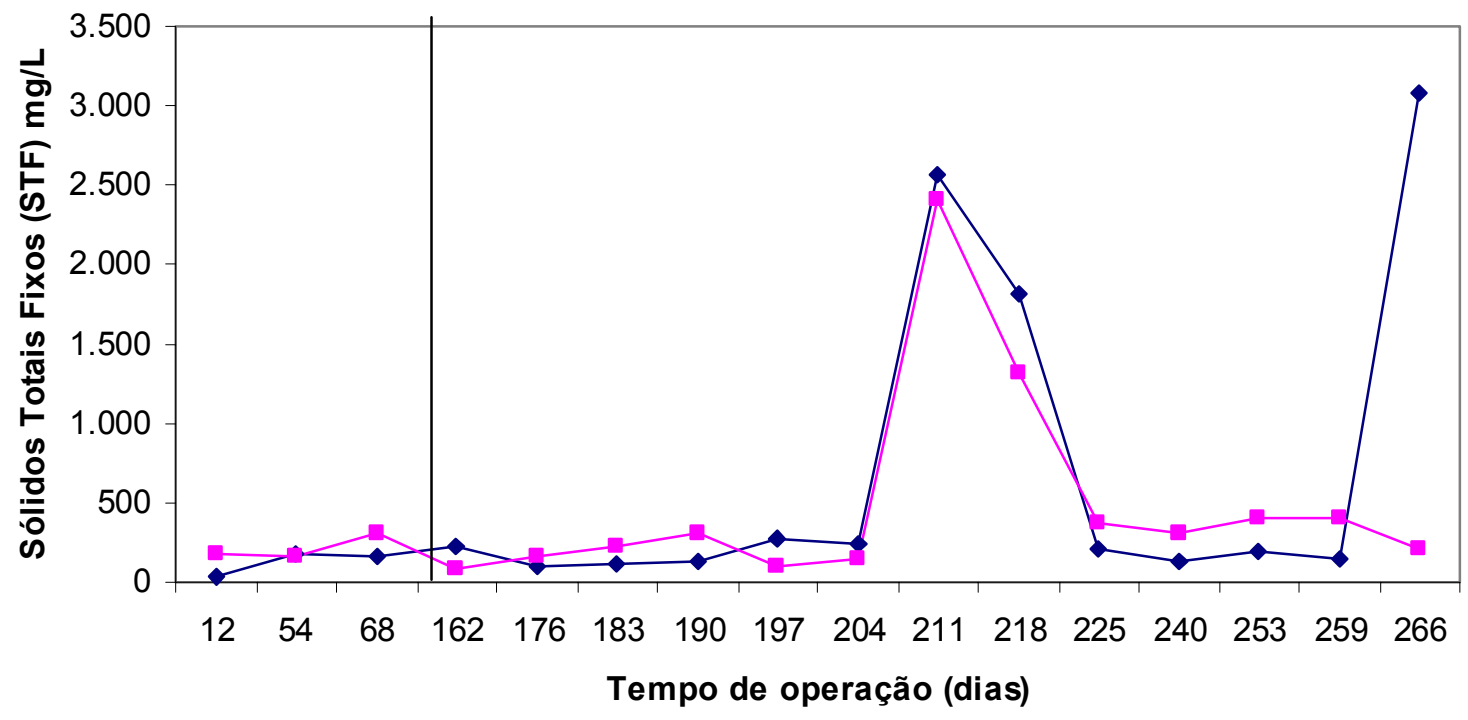

$\rightarrow$ Afl. $\rightarrow$ Efl.

Figura 52 - Variação da concentração de sólidos totais fixos afluente e efluente.

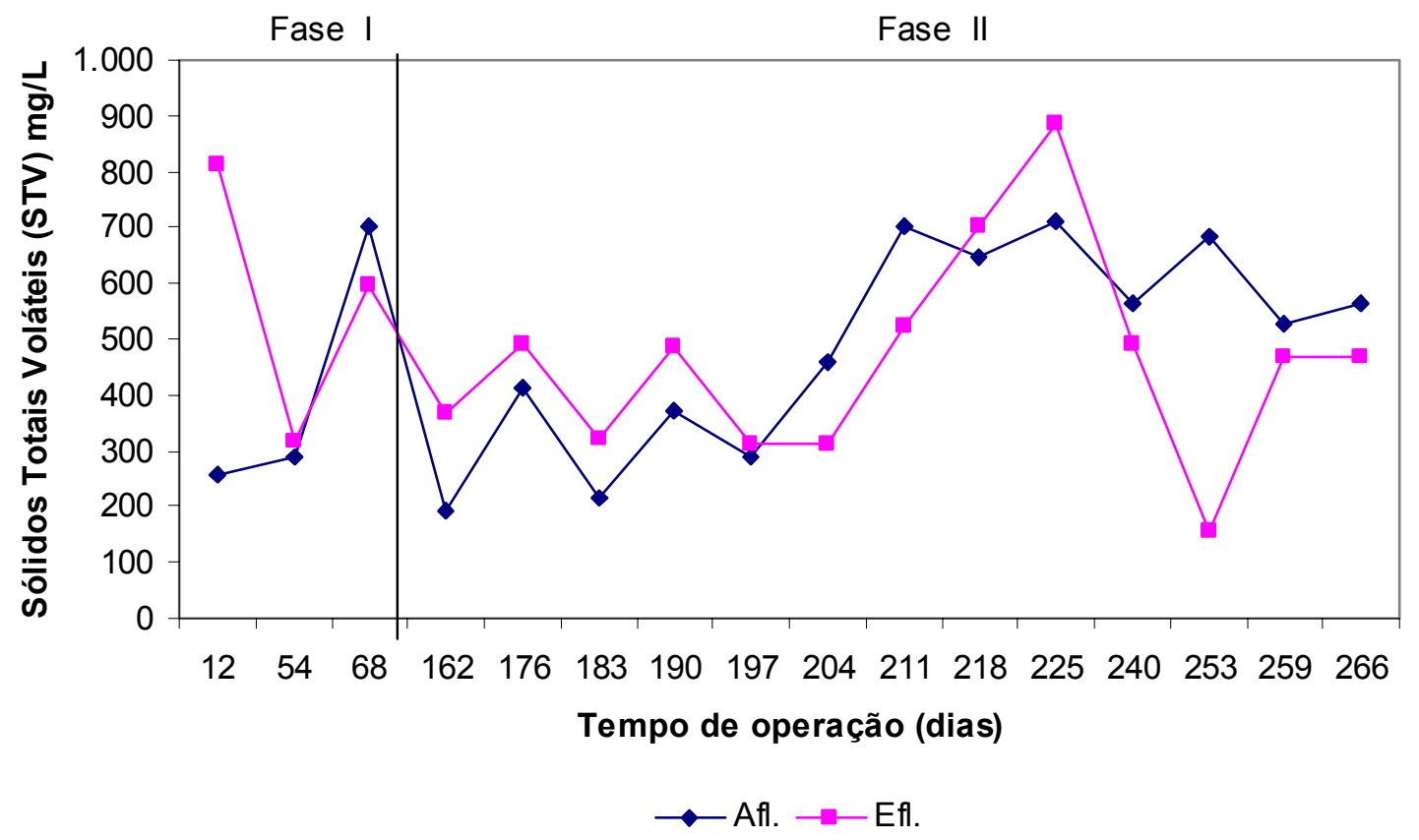

Figura 53 - Variação da concentração de sólidos totais voláteis afluente e efluente.

A Tabela 11 mostra as eficiências de remoção de sólidos suspensos nas fases I e II. Na Fase I, a remoção de SST foi de 30 \% e não houve remoção de SSF. Oliva (1997) obteve durante a partida de UASB, sem inóculo, eficiência média de remoção de SST de $60 \%$, com TDH de 16 horas. Embora ocorram quedas de eficiências quando da operação em escala real em torno de $20 \%$, como discutido na revisão 
bibliográfica, conclui-se que a sobrecarga hidráulica também afetou o desempenho do reator na remoção de sólidos suspensos, como ocorreu com a remoção de DQO.

Na Fase II, a eficiência média de remoção de SST foi de $60 \%$, com eficiência máxima de $85 \%$. Ressalta-se que o valor mínimo de $29 \%$ de remoção de SSV corresponde ao dia 211, lançamento de lodo de limpa-fossas, período anterior ao início da provável estabilização do reator, mostrando que o lançamento de lodo prejudicou a razoável eficiência de remoção que vinha sendo obtida (Figura 56). Ekman (2000) também relata remoção de sólidos suspensos bastante variável no primeiro ano de operação do reator UASB da ETE de Caxias do Sul, o que foi atribuído a variações de carga hidráulica.

Observa-se que mesmo com TDH de 3 horas (dia 204), não houve aumento de SST no efluente como observado por Singh \& Viraraghavan (2003) em escala de bancada, para este mesmo $\mathrm{TDH}$, com temperatura entre 20 e $30^{\circ} \mathrm{C}$ (semelhante à observada em Água Vermelha).

Tabela 11 - Valores médios, mínimos e máximos e o número de dados analisados (n) do parâmetro SS e respectiva eficiência durante as fases I e II.

\begin{tabular}{lllllll}
\hline \multirow{2}{*}{ Eficiência (\%) } & \multicolumn{2}{l}{ Fase I } & \multicolumn{5}{l}{ Fase II } \\
\cline { 2 - 7 } & SST & SSF & SSV & SST & SSF & SSV \\
\hline Méd. & 30 & NR & 40 & 60 & 81 & 55 \\
Mín. & 0 & NR & 0 & 30 & 30 & 30 \\
Máx. & 55 & NR & 45 & 85 & 100 & 80 \\
\hline N & 6 & 6 & 5 & 13 & 11 & 13 \\
\hline
\end{tabular}

NR: não ocorreu remoção da variável analisada.

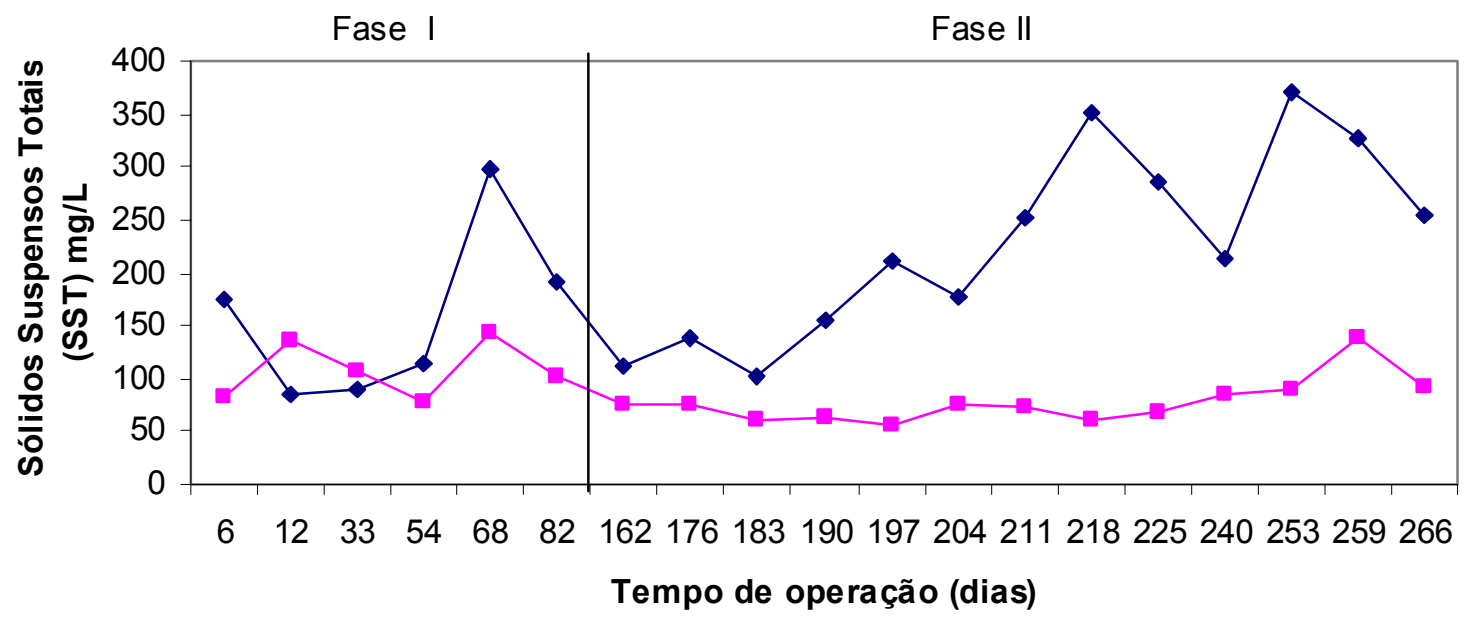

$\rightarrow$ Afl. $\rightarrow$ Efl.

Figura 54 - Variação das concentrações afluente e efluente de sólidos suspensos totais 


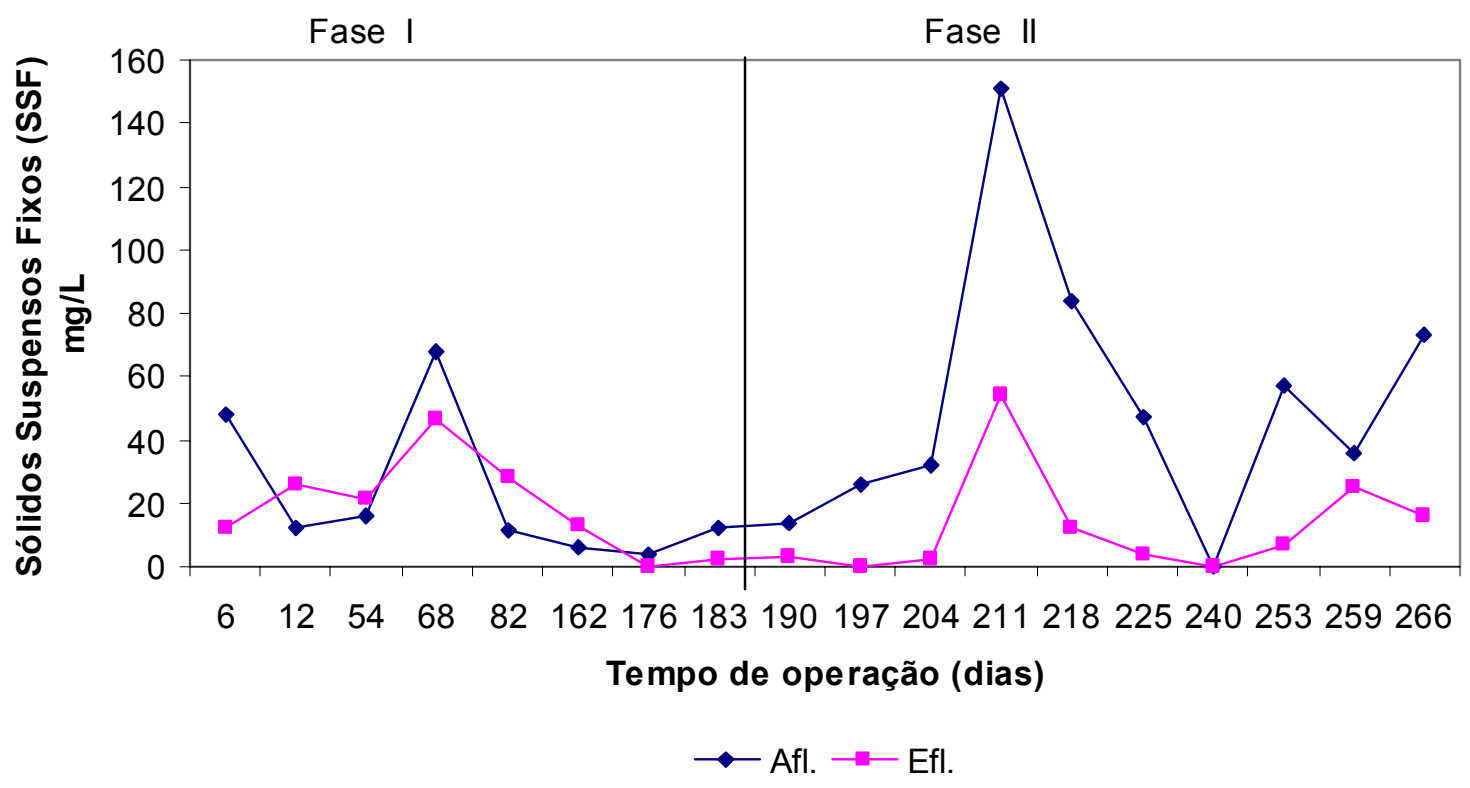

Figura 55 - Variação das concentrações afluente e efluente de sólidos suspensos fixos.

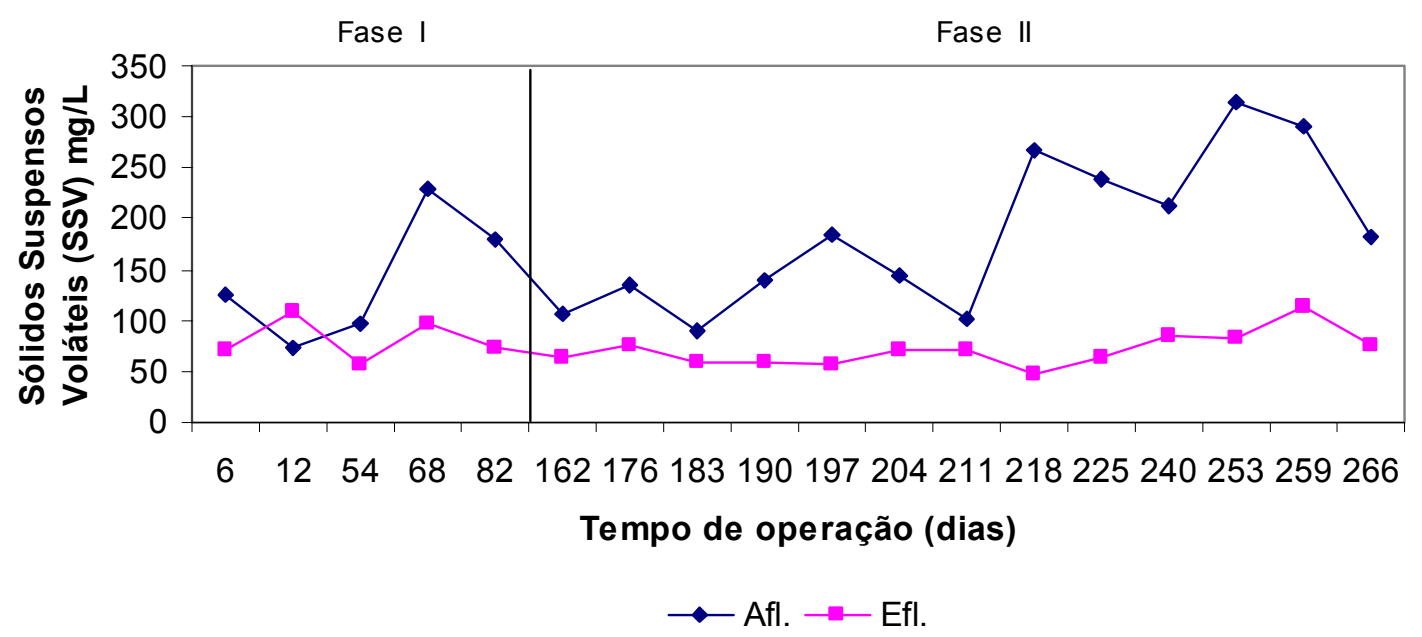

Figura 56 - Variação das concentrações afluente e efluente.de sólidos suspensos voláteis

Da Figura 57 a Figura 59 pode-se observar a variação da concentração de sólidos dissolvidos totais (SDT), fixos e voláteis. Pode-se inferir destas figuras que o pico de sólidos proveniente do lançamento de lodo dos caminhões limpa-fossas não foi absorvido na ocasião em que o reator UASB ainda encontrava-se em fase de adaptação, como pôde ser observado pela ocorrência do pico de sólidos no efluente para o dia 211 de operação. Na ocorrência posterior de lançamento de lodo, dia 266, observa-se que o pico de sólidos não se repetiu no efluente, sendo absorvido no UASB. Nota-se que nas quatro semanas subseqüentes aos dois primeiros lançamentos (dias 211 e 218) o reator apresentou maiores valores de SDT, SDF e SDV no efluente em relação ao afluente, o que também se refletiu nos ST e STF. 


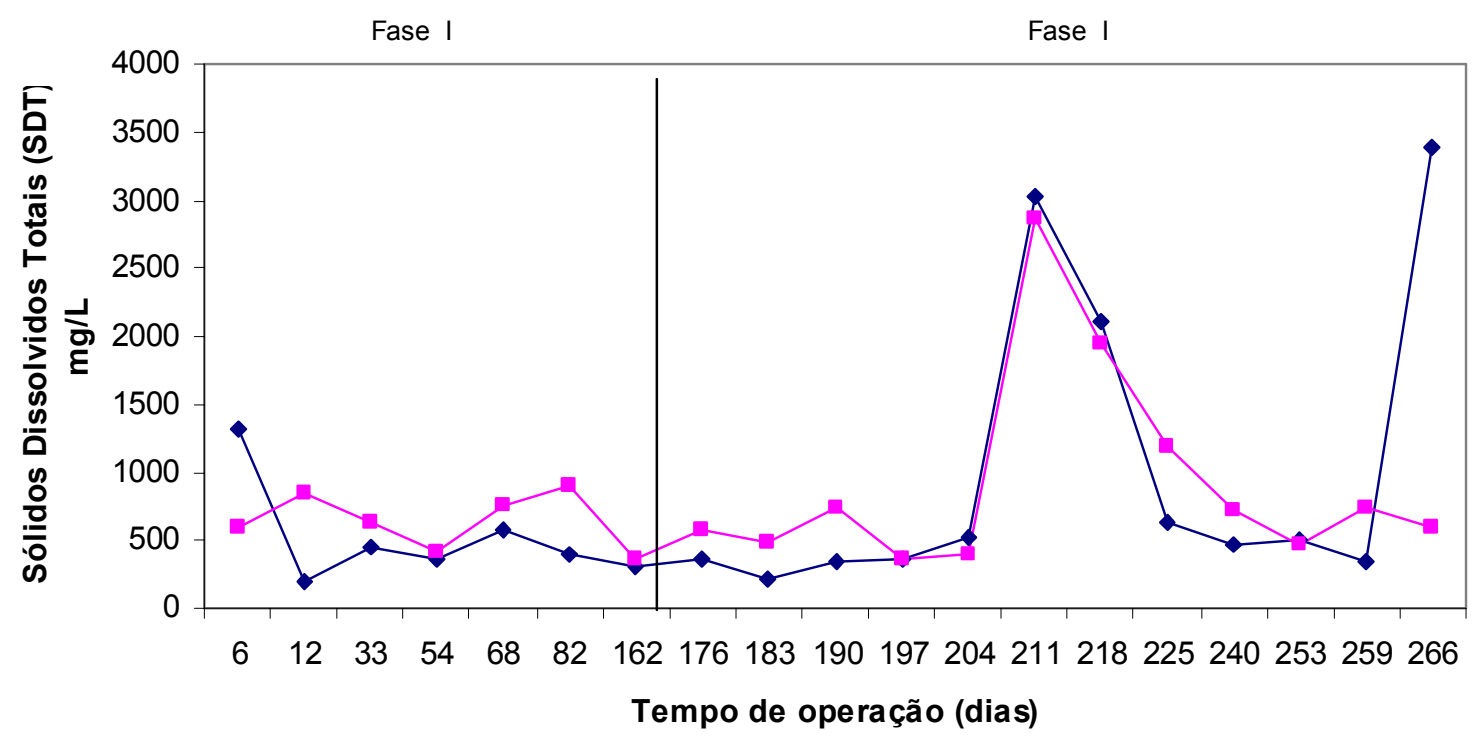

$\multimap$ Afl. $\longrightarrow$ Efl.

Figura 57 - Variação das concentrações afluente e efluente de sólidos dissolvidos totais ao longo do tempo.

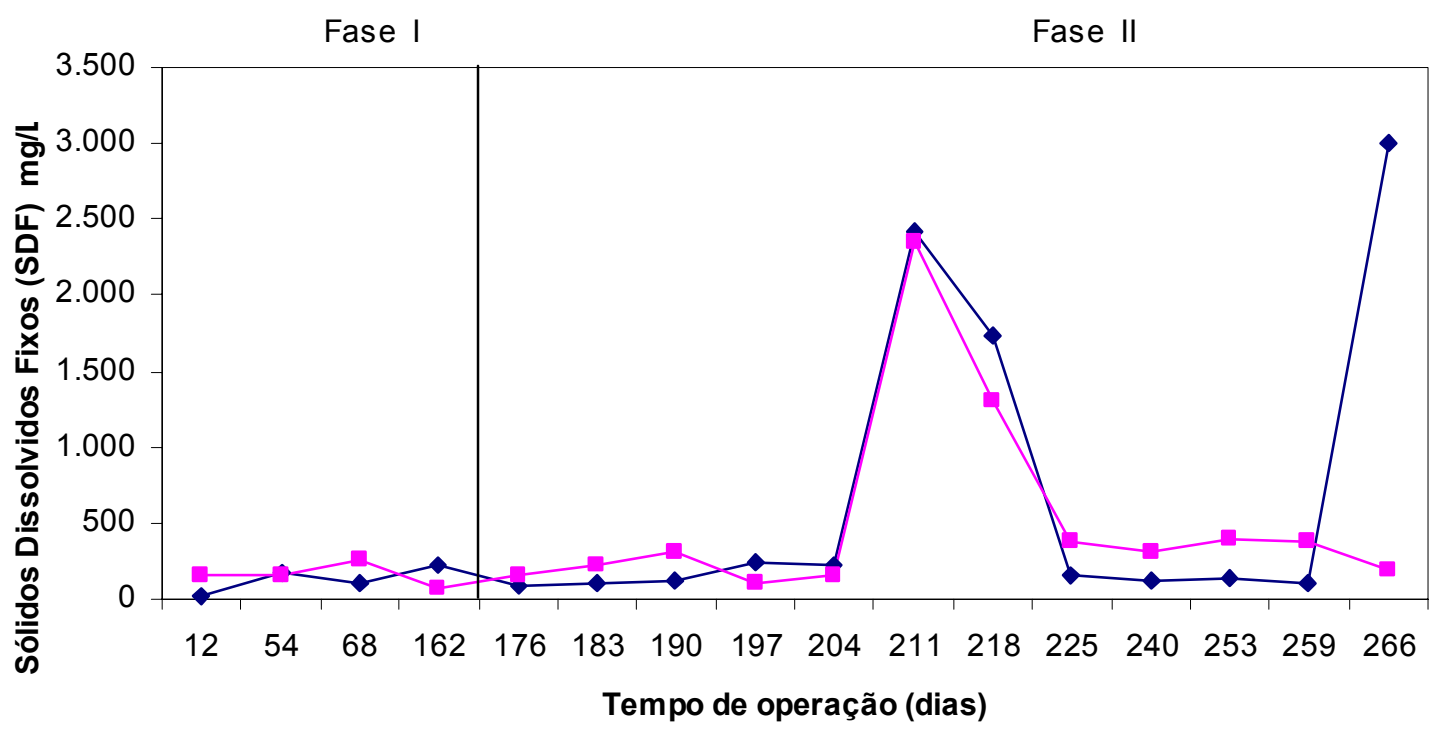

$\multimap$ Afl. $\longrightarrow$ Efl.

Figura 58 - Variação das concentrações afluente e efluente de sólidos dissolvidos fixos ao longo do tempo. 


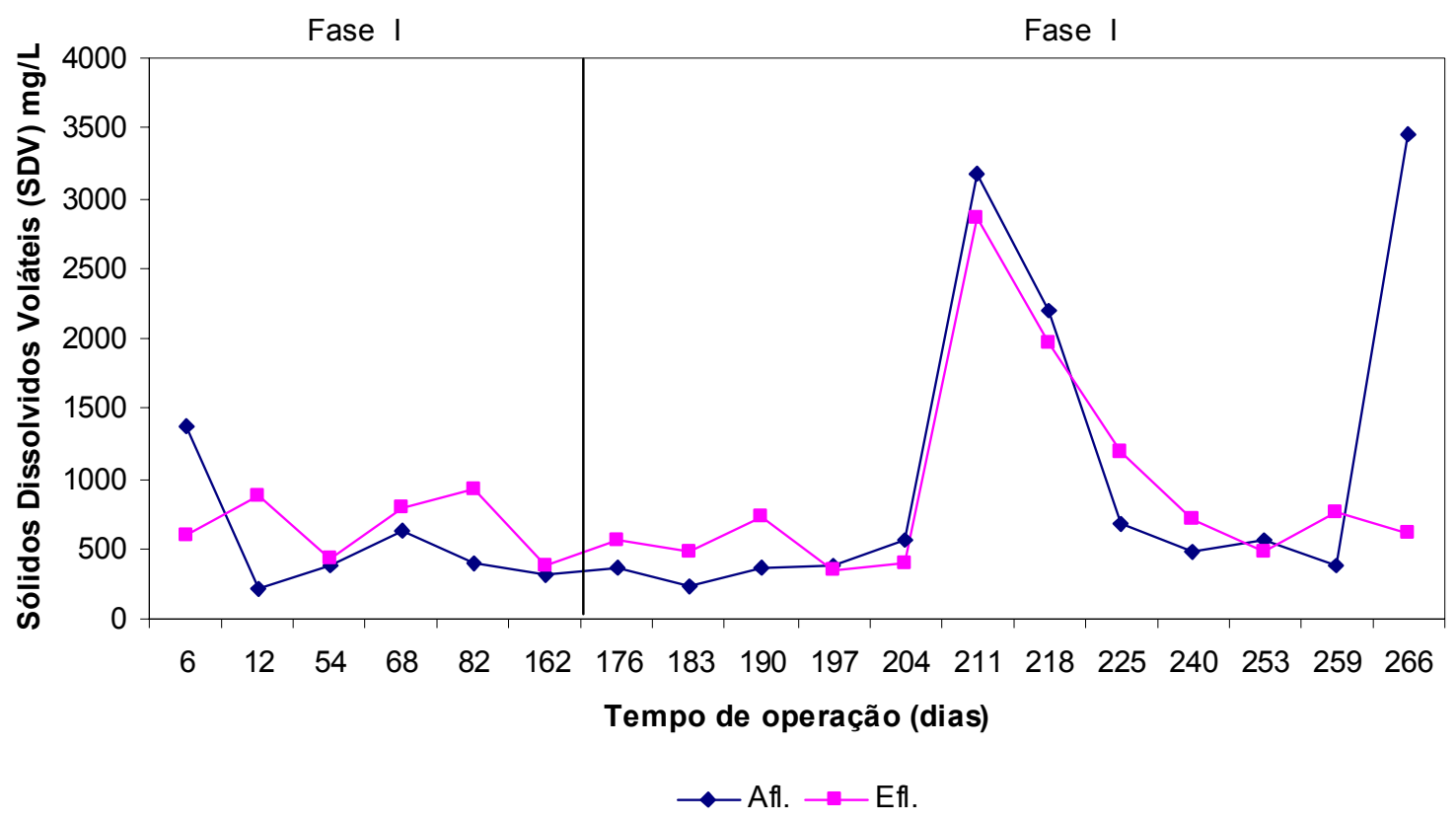

Figura 59 - Variação das concentrações afluente e efluente de sólidos dissolvidos voláteis ao longo do tempo.

Da Figura 60 a Figura 66 são apresentadas as variações das concentrações da série de sólidos ao longo da altura do reator, permitindo avaliar a expansão da manta de lodo.

A variação da concentração de sólidos no leito de lodo $(0,25 \mathrm{~m}$ de altura) pode ser vista na Figura 60. Na Fase I, a partir do dia 54 de operação, observou-se período de crescimento dos sólidos acentuado que, duas semanas depois, havia se modificado para um crescimento contínuo e aproximadamente uniforme até o fim da fase. Nota-se que após a inoculação (Fase II), houve inicialmente uma perda de sólidos, provavelmente causada pelo descarte efetuado pela válvula localizada a $0,15 \mathrm{~m}$ de altura, que se acreditava estar posicionada a 1,20 m, como especificado em projeto. No entanto, outros dois fatores podem também ter contribuído para a perda de sólidos, como também ocorreu no estudo de Rissoli \& Bernardes (2005). São eles: um processo de seleção da biomassa, que deixou o reator, e uma produção lenta de biomassa na fase inicial de adaptação do lodo.

Aproximadamente 40 dias depois, na nova coleta, os sólidos apresentaram crescimento acelerado por duas semanas (como observado também para a Fase I), seguida por um crescimento contínuo e uniforme, dando indicações de que a biomassa adaptou-se, estabelecendo equilíbrio ecológico. Nota-se que os leitos formados nas fases I e II, embora tivessem concentrações semelhantes, possuíam habilidades de remoção diferentes, sendo a da Fase II bastante superior. 


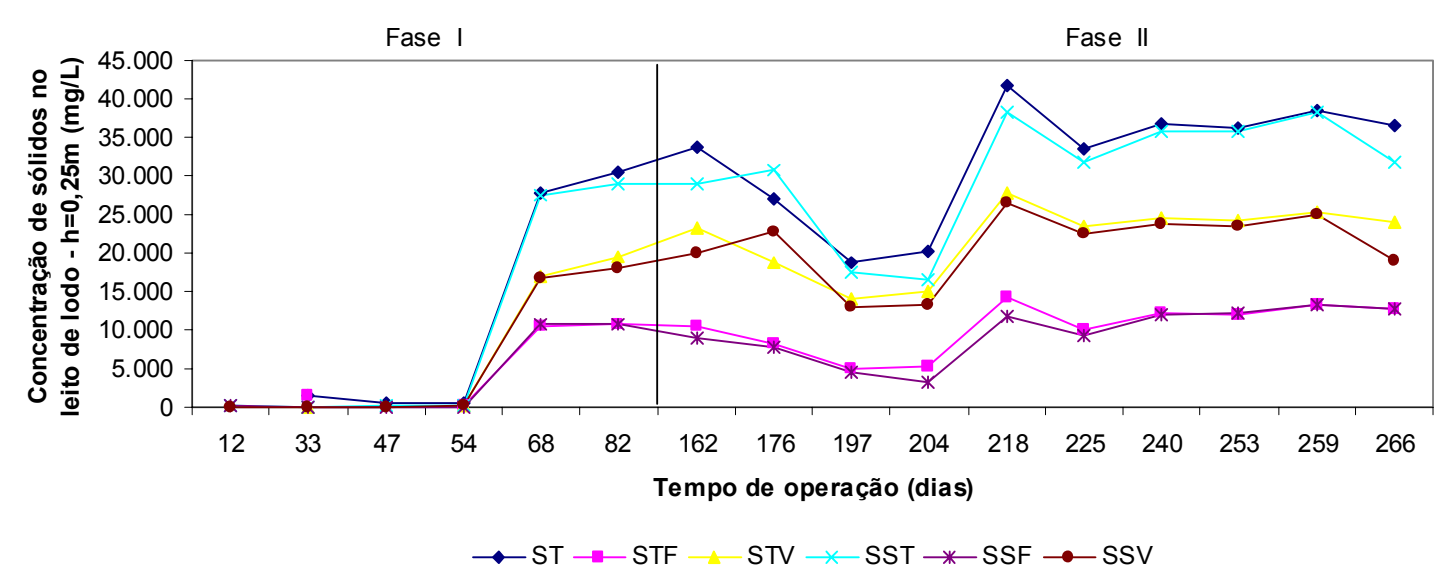

Figura 60 - Variação da concentração de sólidos no leito de lodo (0,25 m de altura).

Não houve crescimento de massa de sólidos na Fase I em nenhuma das alturas acima do leito, mostrando que as características do esgoto de concentrações médias e as velocidades ascensionais elevadas aplicadas não favoreceram o desenvolvimento da biomassa. Na Fase II o crescimento acentuado iniciou-se antes para a altura de 0,85 m, em relação a todas as outras alturas de coleta. Após este período, o comportamento foi semelhante ao observado para a altura de $0,25 \mathrm{~m}$.

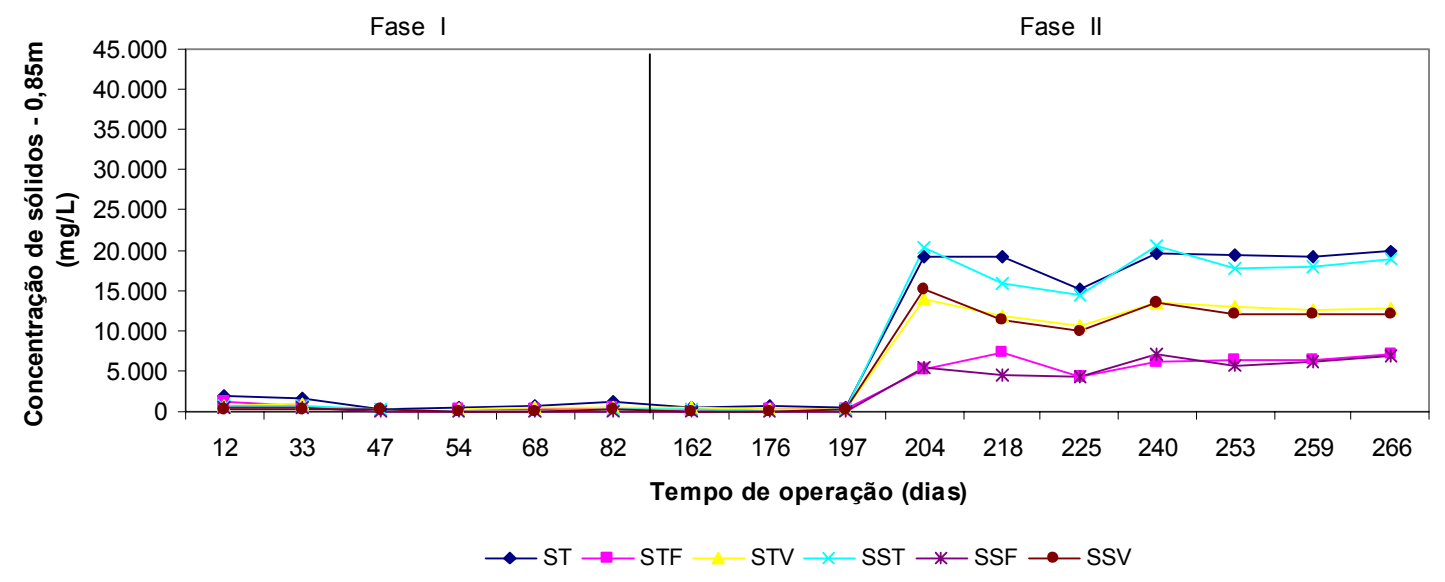

Figura 61 - Variação da concentração de sólidos a 0,85 m de altura.

Para as alturas de $1,45 \mathrm{~m}, 2,05 \mathrm{~m}$ e 2,65 m o aumento da concentração de sólidos teve o mesmo comportamento observado a $0,25 \mathrm{~m}$. 


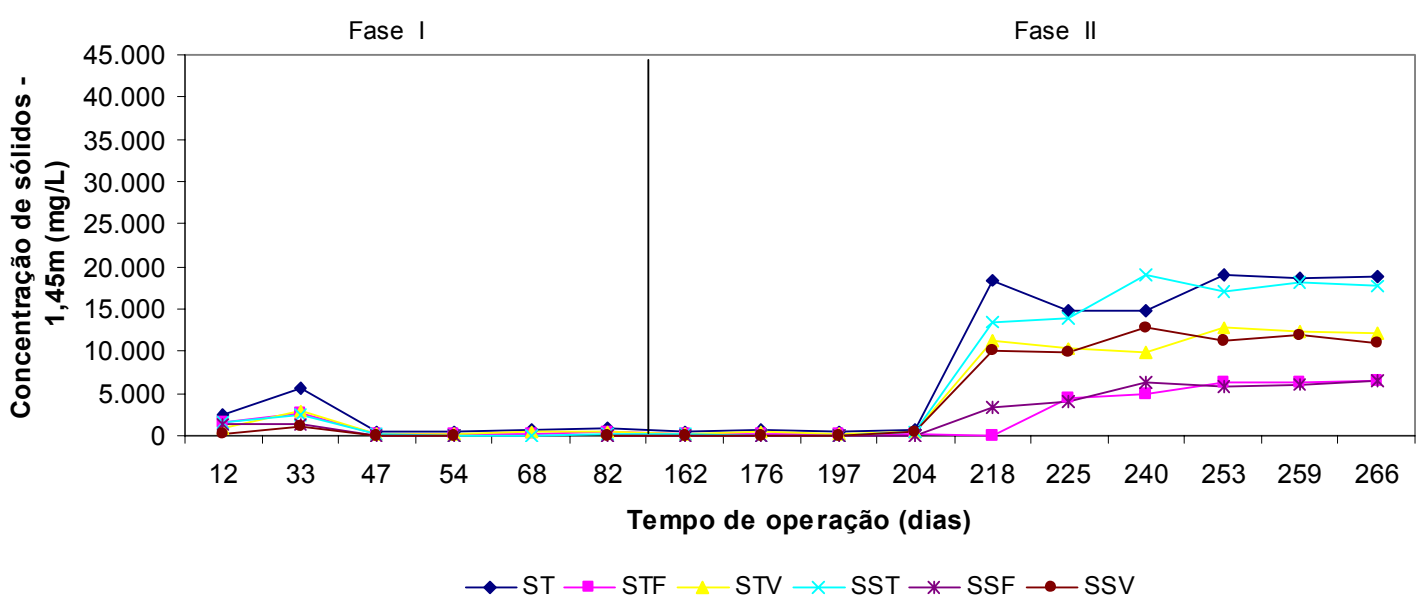

Figura 62 - Variação da concentração de sólidos a 1,45 m de altura.

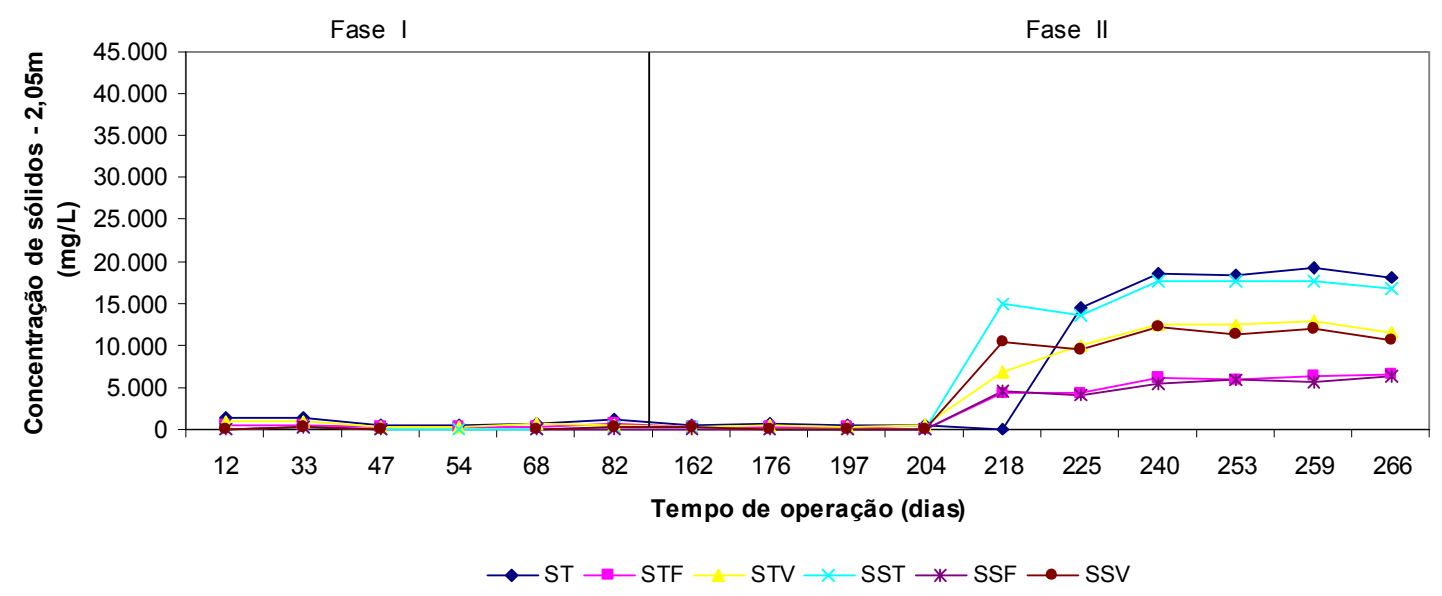

Figura 63 - Variação da concentração de sólidos a 2,05 m de altura.

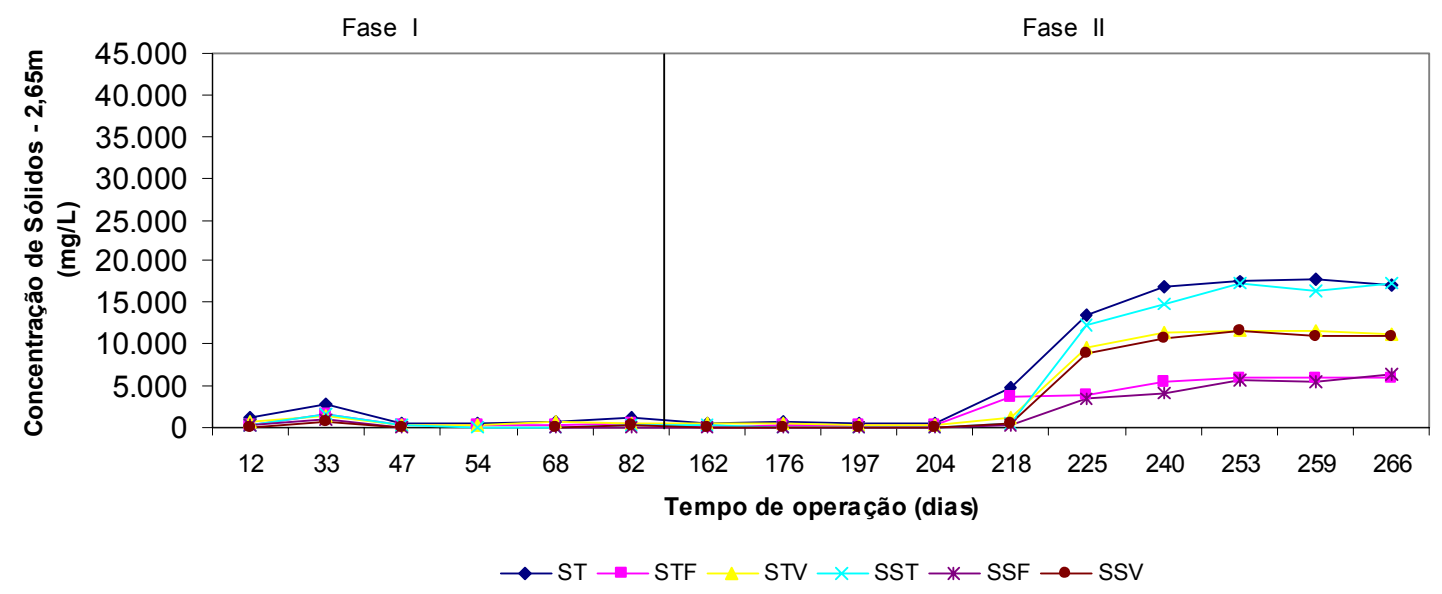

Figura 64 - Variação da concentração de sólidos a 2,65 m de altura.

Para 3,25 $\mathrm{m}$ de altura o crescimento também foi observado com aproximadamente 40 dias, porém se estendeu por 20 dias (tempo maior que nas alturas inferiores). Ressalta-se que o baixo valor de concentração observado no dia 240 de 
operação provavelmente se deve à baixa vazão afluente registrada neste dia, pois a baixa vazão proporciona menores velocidades ascensionais e conseqüentemente menor ressuspensão da manta. Então, este dado seria considerado fora do padrão de coleta, como se tivesse sido lido fora do horário normalmente utilizado. Aproximadamente 60 dias após a inoculação (225 dia) a manta atingiu 3,25 $\mathrm{m}$ de altura.

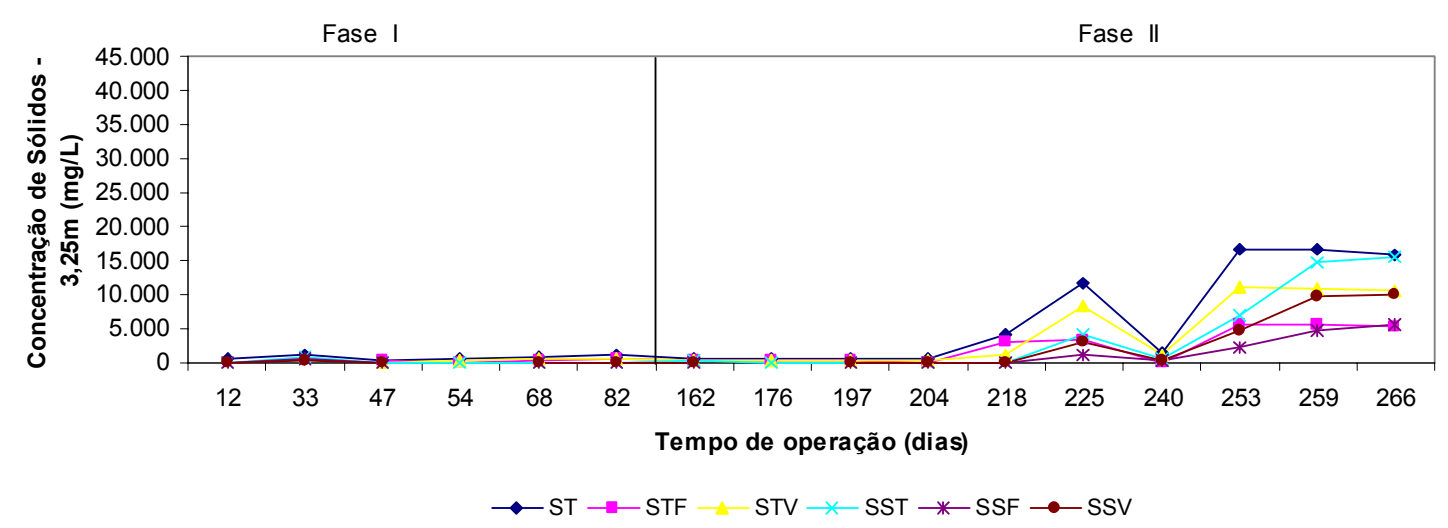

Figura 65 - Variação da concentração de sólidos a 3,25 m de altura.

O aumento da concentração de sólidos, a 3,85 m de altura, iniciou-se com 100 dias após a inoculação (dia 259). Este fato gerou a necessidade de se efetuar o descarte do lodo excedente, pois houve aumento de sólidos totais e DQO no efluente, fazendo com que não ocorresse remoção destes parâmetros.

Nota-se que à altura de $3,85 \mathrm{~m}$ a manta de lodo estava acima do defletor, atingindo o ínicio do separador de fases.

Observando que a manta sobe aproximadamente $12 \mathrm{~cm} /$ semana, se pode então estabelecer que seja feito um descarte de $8,5 \mathrm{~m}^{3} / \mathrm{mês}$, tempo condizente com o recomendado por SANEVIX (2003) para que o lodo permaneça no leito de secagem para estabilização, podendo então ser removido para dar espaço ao novo descarte. $\mathrm{O}$ intervalo entre descartes recomendado em SANEVIX (2003) é de 1 a 2 meses. A ETE Água Vermelha provavelmente requereu menor intervalo devido ao lançamento de lodo de limpa-fossas. O volume descartado pode ser medido na parede do leito de secagem. Quando a altura de lodo atingir 0,15 m tem-se o volume de lodo desejado descartado.

Como o aumento de sólidos observado no dia 218 não persistiu nos dias seguintes (até o dia 253), acredita-se que este aumento pontual tenha sido devido ao lançamento de lodo de limpa-fossas que ocorreu neste dia. Oliva (1997) também observou, durante a operação do reator UASB utilizado na pesquisa, que a concentração de sólidos chegava a variar durante um mesmo dia nas diversas tomadas de 
amostragem. Durante ensaios de repostas dinâmicas às sobrecargas hidráulicas, aumentando $50 \%$ a vazão afluente foram observadas sistematicamente concentrações mais elevadas na tomada de leitura a $0,90 \mathrm{~m}$ do fundo do reator, pela manhã, antes de provocar-se o pulso de vazão, e concentrações sensivelmente mais elevadas na tomada acima (1,80 m), no período da tarde, antes de iniciar-se novo pulso de vazão.

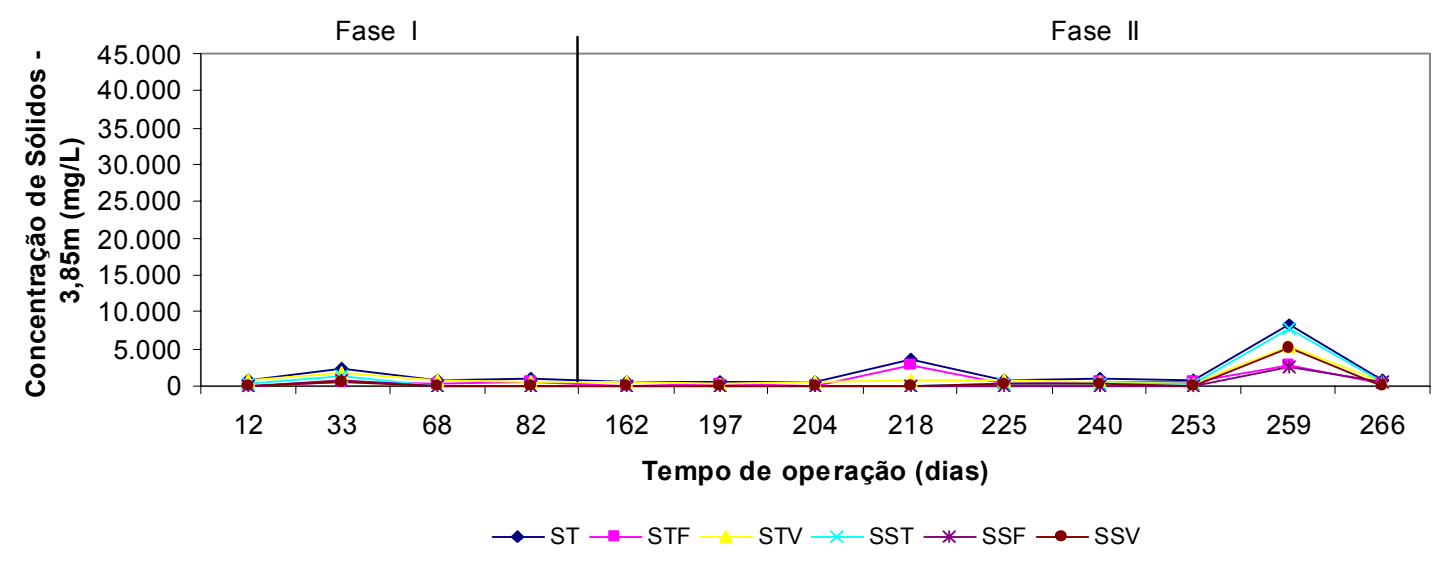

Figura 66 - Variação da concentração de sólidos a 3,85 m de altura.

A Figura 67 mostra a variação da concentração dos sólidos sedimentáveis (SS) ao longo da altura do reator. Pode-se observar no dia 259 o aumento da quantidade de SS na altura de 3,85 m, ocasião em que se optou pelo descarte. A média de SS mantevese em $0,2 \mathrm{~mL} / \mathrm{L}$ do início do experimento até o dia 218 de operação; do $225^{\circ}$ ao $253^{\circ}$ dia de operação a média foi de $2 \mathrm{~mL} / \mathrm{L}$, atingindo $150 \mathrm{~mL} / \mathrm{L}$ no referido dia 259 e após o descarte do lodo excedente retornou para $2 \mathrm{~mL} / \mathrm{L}$.

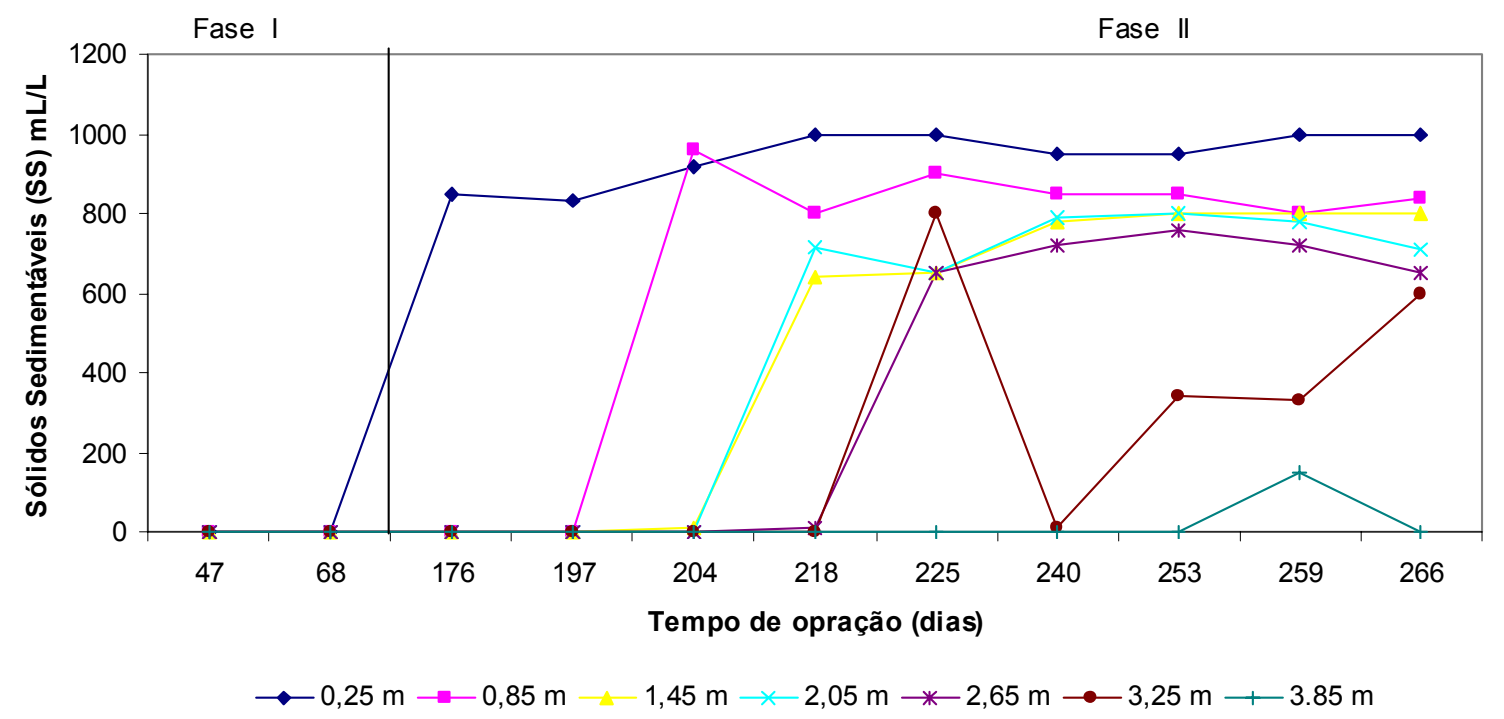

Figura 67 - Variação dos sólidos sedimentáveis a ao longo da altura do reator. 
As concentrações de ST variam claramente ao longo da altura do reator. Na Fase I, sem adição de inóculo, observa-se a formação do leito de lodo a partir de 60 dias de operação, com concentrações próximas às da Fase II, mas sem ocorrência de formação da manta de lodo (Figura 68a). Oliva (1997) obteve, em reator de $18 \mathrm{~m}^{3}$, os mesmos resultados, porém operando em condições hidráulicas ideais.

Na Figura 68b, observa-se a formação da manta e do leito de lodo, com 60 dias de operação, com inoculação. A Figura 69a mostra o leito e a manta, antes do descarte de lodo, onde se pode observar o excesso de sólidos na parte mais alta do reator, fato que provocou carreamento de sólidos, obtendo-se eficiência negativa na remoção de ST. A Figura 69b mostra o final da Fase II, depois de efetuado o descarte. A diminuição da altura da manta de lodo proporcionou eficiência de remoção de ST de 82 \%.

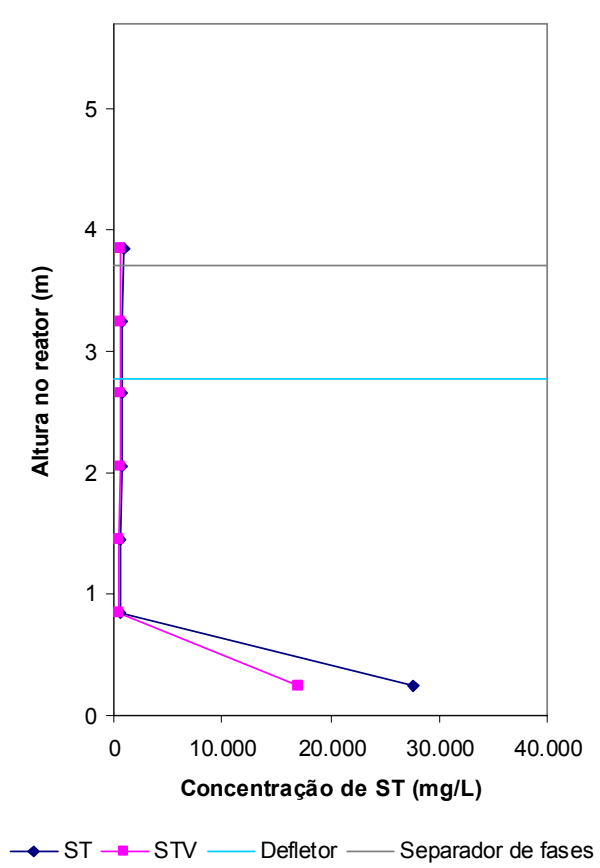

(a)

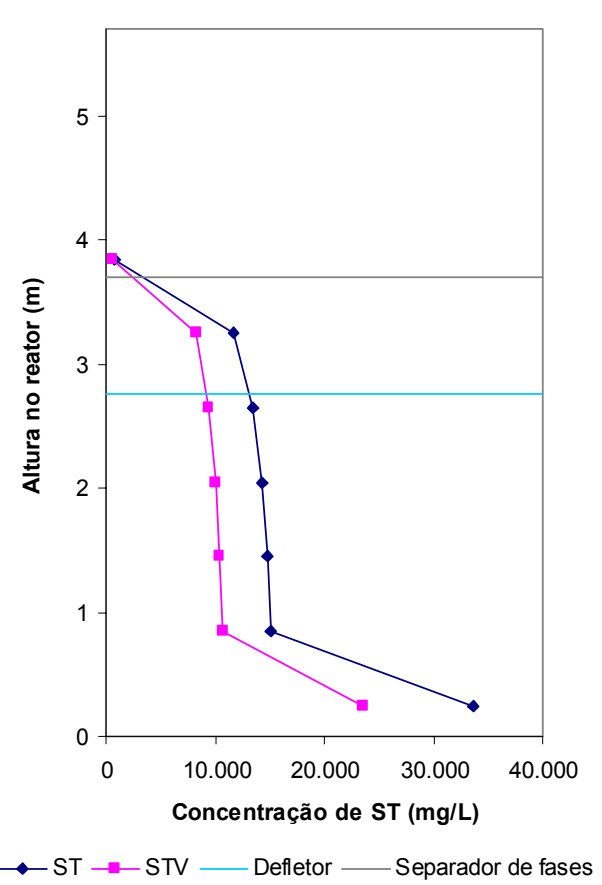

(b)

Figura 68 - Perfil de sólidos totais e voláteis no reator, com 60 dias de operação da Fase I, sem inóculo e com 60 dias de operação Fase II, com inoculação.

A diminuição da concentração de sólidos totais com o aumento da altura indica o bom adensamento do lodo misto (lodo anaeróbio do UASB + lodo aeróbio do BAS) no interior do reator (Tabela 12). A tabela D1 em anexo mostra os valores de adensamento ao longo de toda a pesquisa. 


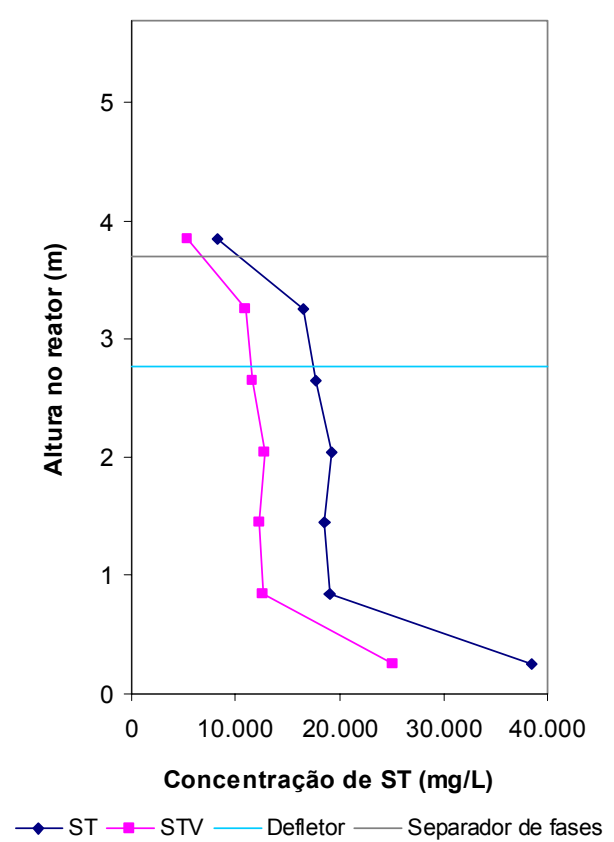

(a)

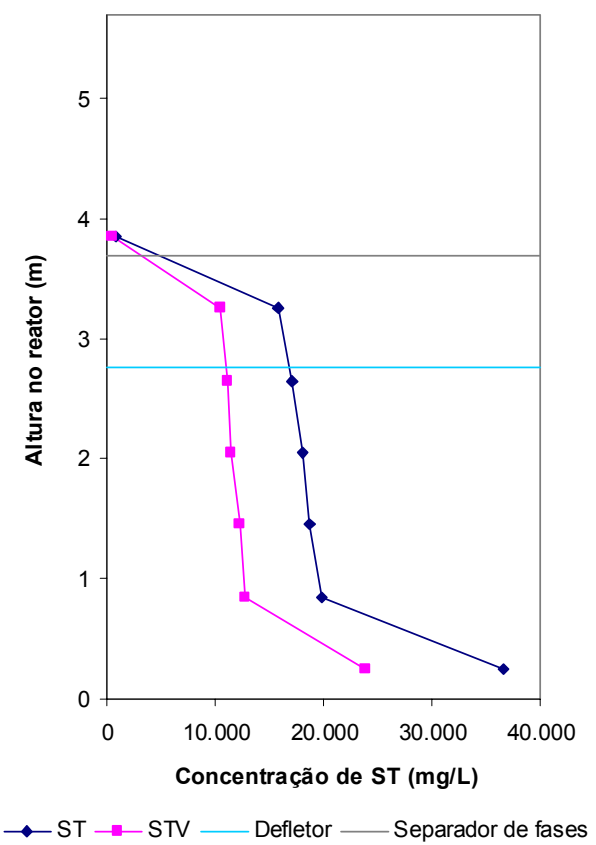

(b)

Figura 69 - Perfil de sólidos totais e voláteis no reator, na da Fase II - 97 dias de operação com inóculo (a) antes do descarte e no final da Fase II - 104 dias de operação, após o descarte de $8,5 \mathrm{~m}^{3}$ de lodo do UASB (b).

Tabela 12 - Porcentagem de sólidos em massa (\% STV/ST) para as alturas de $0,25 \mathrm{~m}$, 0,85 m e 1,45 m para 80 dias de operação da Fase I, 60 dias de operação da Fase II e final do experimento.

\begin{tabular}{llll}
\hline \multirow{2}{*}{$\begin{array}{l}\text { Altura no } \\
\text { reator (m) }\end{array}$} & STV/ST (\%) & & \\
\cline { 2 - 4 } & $\begin{array}{l}\text { 80 dias de } \\
\text { operação da fase I }\end{array}$ & $\begin{array}{l}\text { 60 dias de operação } \\
\text { da fase II }\end{array}$ & $\begin{array}{l}\text { Final do } \\
\text { experimento }\end{array}$ \\
\hline 0,25 & 64 & 70 & 65 \\
0,85 & 51 & 71 & 64 \\
1,45 & 52 & 70 & 65 \\
\hline
\end{tabular}

Na região do leito de lodo a $0,25 \mathrm{~m}$ onde se situa a zona de mistura dos lodos anaeróbio (UASB) e aeróbio (BAS), os valores de STV/ST indicam um lodo com boa sedimentabilidade. Foram observados para esta relação valores de $64 \%$ para 80 dias de operação da Fase I; 70 \% para 60 dias de operação da Fase II (quando ocorreu a formação da manta de lodo) e $65 \%$ para o final do experimento. Para as alturas de 0,85 m e 1,45 m, observa-se boa sedimentabilidade apenas na Fase II. Estes valores são semelhantes aos obtidos por Paula Junior et al. (2003), que operou reator UASB (26,5 $\mathrm{m}^{3}$ ) com e sem retorno de lodo de BAS $\left(12 \mathrm{~m}^{3}\right)$ na ETE-UFES, obtendo STV/ST de 64 \%. Silva et al. (2005) operando a mesma ETE, também com recirculação, obteve 77,1 
\% de STV/ST. Nos três estudos, houve aumento nos teores de ST e STV no leito de lodo quando recirculado lodo aeróbio de BAS, já que os valores obtidos para reatores tratando exclusivamente esgoto sanitário situam-se normalmente entre 45 e $55 \%$ de $\mathrm{STV} / \mathrm{ST}$.

\subsection{Caracterização do lodo do BAS recirculado para o UASB}

A Tabela 13 mostra os valores médios dos parâmetros analisados no lodo que era retirado do biofiltro em sua lavagem, que era recirculado para o UASB.

Tabela 13 - Concentrações médias de sólidos no lodo de lavagem do biofiltro aerado submerso.

\begin{tabular}{lll}
\hline Variável & Valor médio & Unidade \\
\hline ST & 6376 & $\mathrm{mg} / \mathrm{L}$ \\
STF & 1762 & $\mathrm{mg} / \mathrm{L}$ \\
STV & 4614 & $\mathrm{mg} / \mathrm{L}$ \\
SST & 5492 & $\mathrm{mg} / \mathrm{L}$ \\
SSF & 1373 & $\mathrm{mg} / \mathrm{L}$ \\
SSV & 4119 & $\mathrm{mg} / \mathrm{L}$ \\
SS & 600 & $\mathrm{~mL} / \mathrm{L}$ \\
\hline
\end{tabular}

\subsection{Produção de sólidos}

A média da produção diária de lodo em relação à DQO aplicada é mostrada na Tabela $14\left(\mathrm{P}_{\text {lodo }}\right)$ em kgSST/dia. Nela também se encontram as médias dos coeficientes de produção de sólidos observados $\left(\mathrm{Y}_{\mathrm{obs}}\right)$ em cada fase da pesquisa, em $\mathrm{kgSST} / \mathrm{kgDQOaplicada}$ ao longo da altura do reator e os valores de projeto esperados. $\mathrm{O}$ fato da produção de lodo e do $\mathrm{Y}_{\mathrm{obs}}$ terem sido calculados em relação à DQO aplicada e não à DQO removida se deve às baixas eficiências obtidas sob as condições de operação de sobrecarga hidráulica. As sobrecargas hidráulicas acarretaram, em algumas semanas, carreamento de sólidos ao invés de acúmulo na manta de lodo, fazendo com que as eficiências de remoção de DQO e de SST fossem negativas, impossibilitando sua inclusão nos cálculos, o que diminui a quantidade de dados disponíveis. Chernicharo (1997) lembra que de acordo com a cinética de crescimento bacteriano e de utilização do substrato, o $\mathrm{Y}_{\mathrm{obs}}$ é expresso em termos da DQO removida do sistema de tratamento 
(kgSSV/kgDQOremov). Todavia, o mesmo autor relata que a experiência brasileira tem indicado valores do coeficiente de produção de sólidos usualmente expressos em termos de sólidos suspensos totais e de DQO aplicada ao sistema, por isto este autor também expressa o $\mathrm{Y}_{\mathrm{obs}}$ em relação à DQO aplicada, visando permitir a comparação com os dados de outros pesquisadores.

Tabela 14 - Valores médios da produção diária de lodo em relação à DQO aplicada em $\mathrm{kgSST} /$ dia, do coeficiente de sólidos observado em $\mathrm{kgSST} / \mathrm{kgDQOaplicada}$ e respectivos valores de projeto esperados.

\begin{tabular}{lllll}
\hline $\begin{array}{l}\text { Altura } \\
(\mathrm{m})\end{array}$ & $\begin{array}{l}\mathrm{Y}_{\text {obs }} \text { - Fase I } \\
(\mathrm{kgSST} / \mathrm{kgDQOa})\end{array}$ & $\begin{array}{l}\mathrm{P}_{\text {lodo }} \text { - Fase I } \\
(\mathrm{kgSST} / \mathrm{dia})\end{array}$ & $\begin{array}{l}\mathrm{Y}_{\text {obs }} \text { - Fase II } \\
(\mathrm{kgSST} / \mathrm{kgDQOa})\end{array}$ & $\begin{array}{l}\mathrm{P}_{\text {lodo }} \text { - Fase II } \\
(\mathrm{kgSST} / \mathrm{dia})\end{array}$ \\
\hline 0,25 & 0,073 & 17,3 & 0,788 & 161,1 \\
0,85 & 0,005 & 1,5 & 0,950 & 87,7 \\
1,45 & 0,064 & 11,2 & 0,419 & 97,5 \\
2,05 & 0,016 & 3,2 & 0,244 & 57,0 \\
2,65 & 0,108 & 1,8 & 0,451 & 64,1 \\
\hline Projeto & $0,15^{(1)}$ & $38,0^{(1)}$ & $0,15^{(1)}$ & $38,0^{(1)}$
\end{tabular}

(1) Os dados de projeto são os encontrados em SANEVIX (2003).

Durante a partida, as condições internas variam muito e conseqüentemente a razão de produção de lodo também, por isso a grande variabilidade dos valores encontrados. Na Fase I, $\mathrm{Y}_{\text {obs }}$ e $\mathrm{P}_{\text {lodo }}$ mostraram-se sempre abaixo do que é normalmente observado na literatura; na Fase II, sempre acima. Chenicharo (1997) cita que os valores reportados para o caso de reatores UASB tratando esgotos domésticos têm sido da ordem de 0,10 a $0,20 \mathrm{kgSST} / \mathrm{kgDQOaplic}$.

Rissoli \& Bernardes (2005), em escala piloto, encontraram valores de $\mathrm{Y}_{\mathrm{obs}}$ de 0,075 kgSST/kgDQOaplic, abaixo dos citados na literatura.

Chernicharo \& Pontes (2005), estudando o efeito do retorno do lodo aeróbio na biomassa de reator UASB de $22 \mathrm{~m}^{3}$, encontraram $0,23 \mathrm{gST} / \mathrm{gDQOaplicada}$ para a produção específica média de sólidos.

\section{$6.10 \mathrm{pH}$}

$\mathrm{O} \mathrm{pH}$ se manteve em torno de 7,2 tanto para o afluente quanto para o efluente ao longo de toda a pesquisa, como se pode observar na Figura 70. Chernicharo (1997) recomenda que este se encontre no intervalo de 6,8 a 7,4 e sempre acima de 6,2. Os 
valores máximos e mínimos para o afluente e efluente respectivamente foram 8,$2 ; 6,7$ e 8,$7 ; 6,3$.

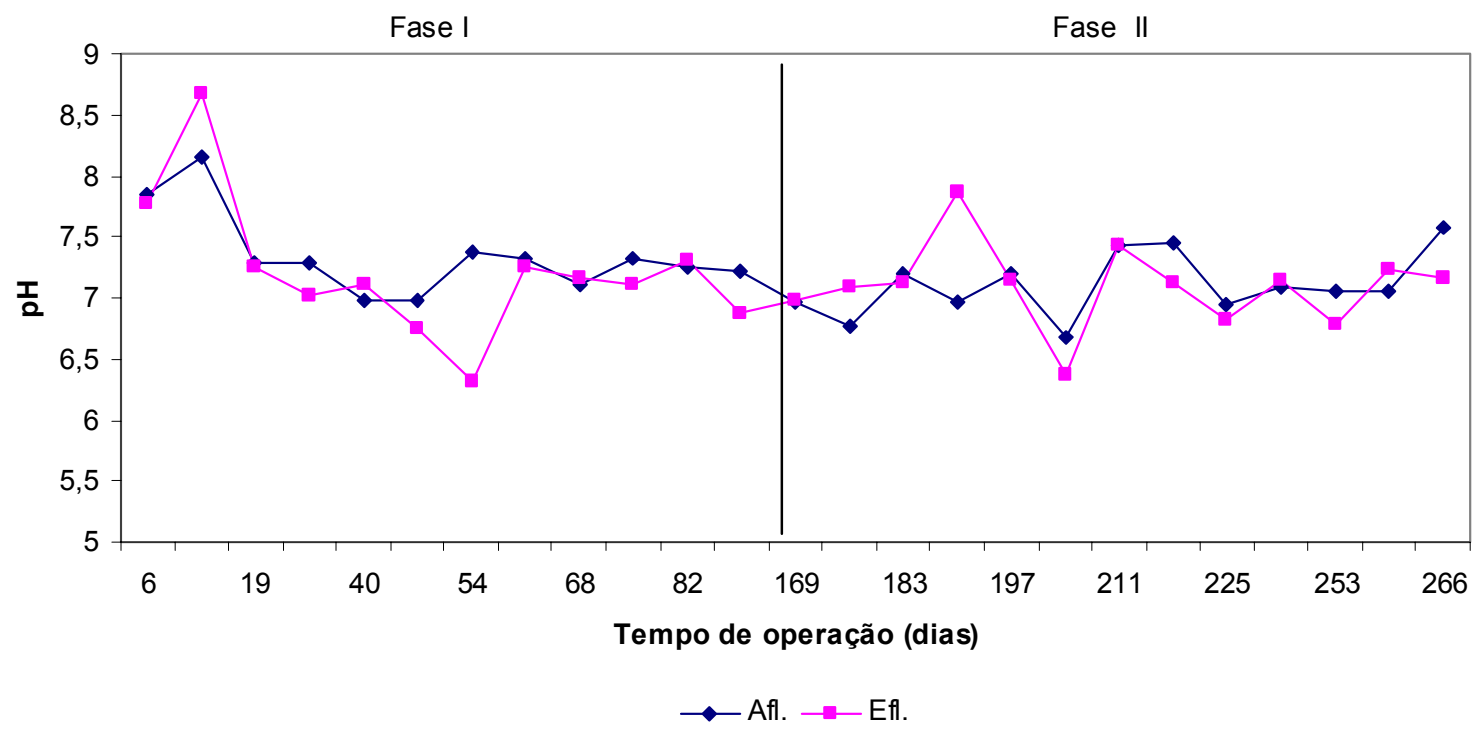

Figura 70 - Variação do pH ao longo do tempo.

Não foi necessária em nenhum momento a adição de produtos químicos para estabilizar o processo, concluindo-se, portanto, que a sobrecarga hidráulica, o retorno de lodo aeróbio e o lançamento de lodo de fossas não afetaram a estabilidade do $\mathrm{pH}$.

\subsection{Alcalinidade parcial e total}

A Figura 71 apresenta a variação de alcalinidade parcial e total ao longo do tempo. Os valores médios de alcalinidade parcial afluente, total afluente, parcial efluente e total efluente foram respectivamente $175,250,185$ e $300 \mathrm{mgCaCO}_{3} / \mathrm{L}$. Observou-se um aumento nos valores na ocasião da entrada de lodo de fossas (dias 211, 218 e 266), tanto para alcalinidades parciais quanto totais, função dos sólidos dissolvidos presentes neste tipo de lodo. 


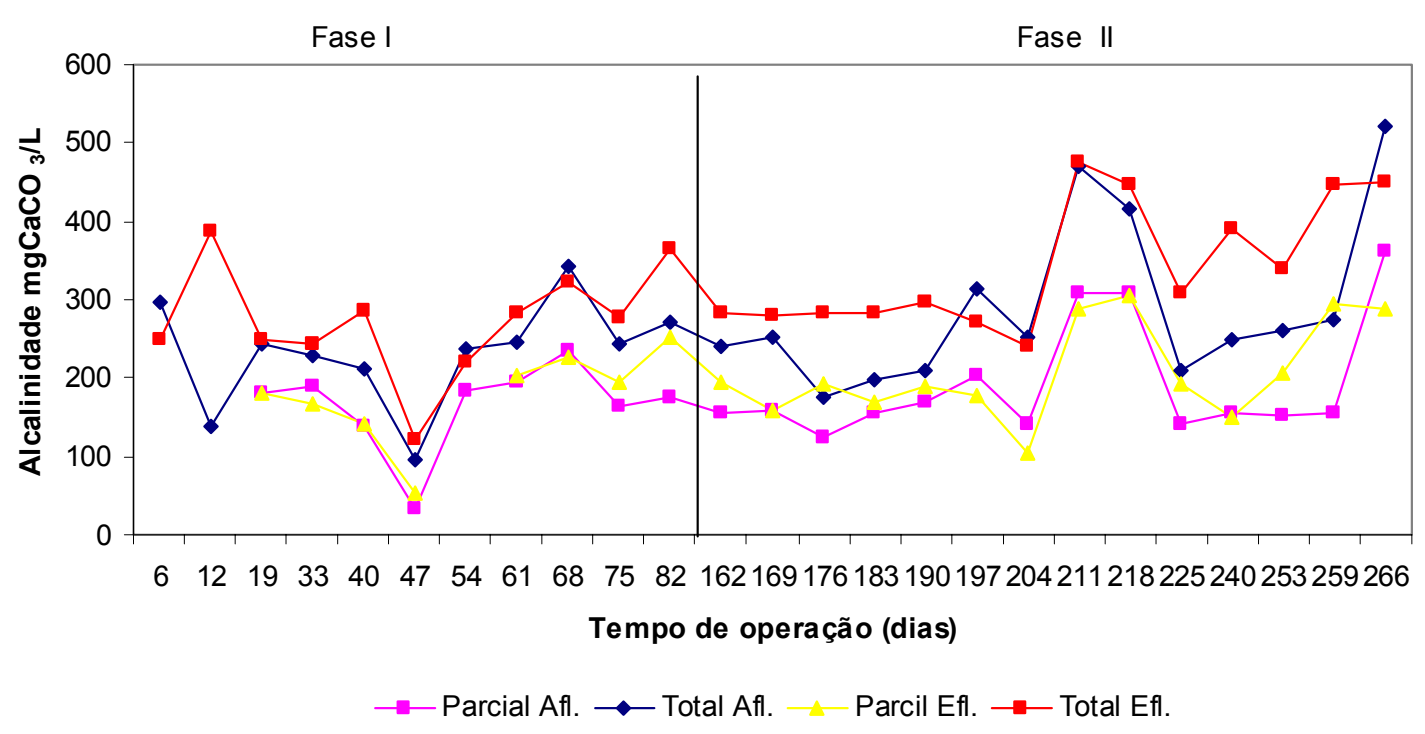

Figura 71 - Variação de alcalinidade total e parcial ao longo do tempo.

\subsection{Relação entre Demanda Bioquímica de Oxigênio (DBO), DQO e}

\section{Carbono Orgânico Filtrado $\left(\mathrm{COT}_{\mathrm{F}}\right)$}

A relação DQO/DBO esperada para esgotos domésticos brutos é de 1,7 a 2,4. No esgoto afluente a ETE Água Vermelha, embora a média desta relação tenha sido de 1,8, observou-se em alguns dias de coleta que esta relação foi de até 3. Valor semelhante também foi encontrado na avaliação do efluente da empresa TAM que foi utilizado no início da Fase I da pesquisa, como apresentado anteriormente na Tabela 8. Esta relação demonstra que embora a ETE tenha sido projetada para o tratamento de efluentes domésticos, em alguns dias podem ter ocorrido lançamentos de efluentes com características não tratáveis por processos biológicos, outro fator que pode ter contribuído para o desempenho insatisfatório do reator.

Segundo Metcalf \& Eddy (2003) para amostras brutas a relação DBO/COT deve situar-se entre 1 e 1,6. Foi avaliada a relação entre as leituras de DBO e COT de amostras filtradas do afluente de Água Vermelha, pois a quantidade de sólidos presentes nas amostras não permitiam que estas fossem introduzidas no aparelho de leitura de COT sem filtração prévia, obtendo-se média de 4,5, valor bastante superior à sugerida pelos autores citados. Para o efluente a média desta relação foi 4,0.

Ressalta-se que foram iniciadas as análises de COT devido ao fato da observação de algumas incoerências nas leituras de DBO; onde em algumas análises se 
obteve valores de DBO de amostras filtradas superiores ao valor das amostras brutas. Isto pode se dever a falhas na análise das amostras, que por possuírem altas concentrações de sólidos em algumas coletas tornavam mais difícil a obtenção de amostras homogêneas para todas as concentrações incubadas.

As concentrações de DBO lidas em amostras brutas e filtradas e de COTf ao longo da pesquisa encontram-se nas tabelas A12 e A16, em anexo. A partir do dia 197 (30 dias após a inoculação) foi observada remoção constante de DBO bruta e filtrada. Nas ocasiões de entrada do lodo das fossas, observou-se aumento no COT filtrado efluente, resultado atribuído à conversão parcial da matéria carbonácea particulada em dissolvida. Após a provável estabilização do reator UASB, na ocasião do novo lançamento de lodo de fossas (dia 266), este aumento não foi observado, mostrando que a manta formada foi capaz de degradar maior parcela do substrato afluente.

\subsection{3 Ácidos Voláteis}

A Figura 72 apresenta variação dos ácidos voláteis afluentes ao longo do tempo. Os ácidos voláteis se mantiveram sempre abaixo de $200 \mathrm{mg} / \mathrm{L}$, como recomendado em Chernicharo (1997) para um bom funcionamento do processo de digestão. No entanto, mostraram-se ainda abaixo dos valores normalmente observados na literatura de $50 \mathrm{mg} / \mathrm{L}$ para efluentes de reatores anaeróbios tratando esgoto sanitário. Cosentino et al. (2005) em estudo em UASB com retorno de lodo aeróbio obteve valores médios efluentes de $85 \mathrm{mg} / \mathrm{L}$ para o ácido acético. Na maior parte das amostras não foi observada remoção de ácidos, provavelmente devido à ocorrência da acidogênese, mas não de conversão em gás, sendo os ácidos liberados no efluente. $\mathrm{Na}$ fase final do experimento (dias 253 e 259) há uma alteração deste comportamento com remoção constante de $50 \%$ para o acido acético, corroborando a hipótese do provável início de estabilização. 


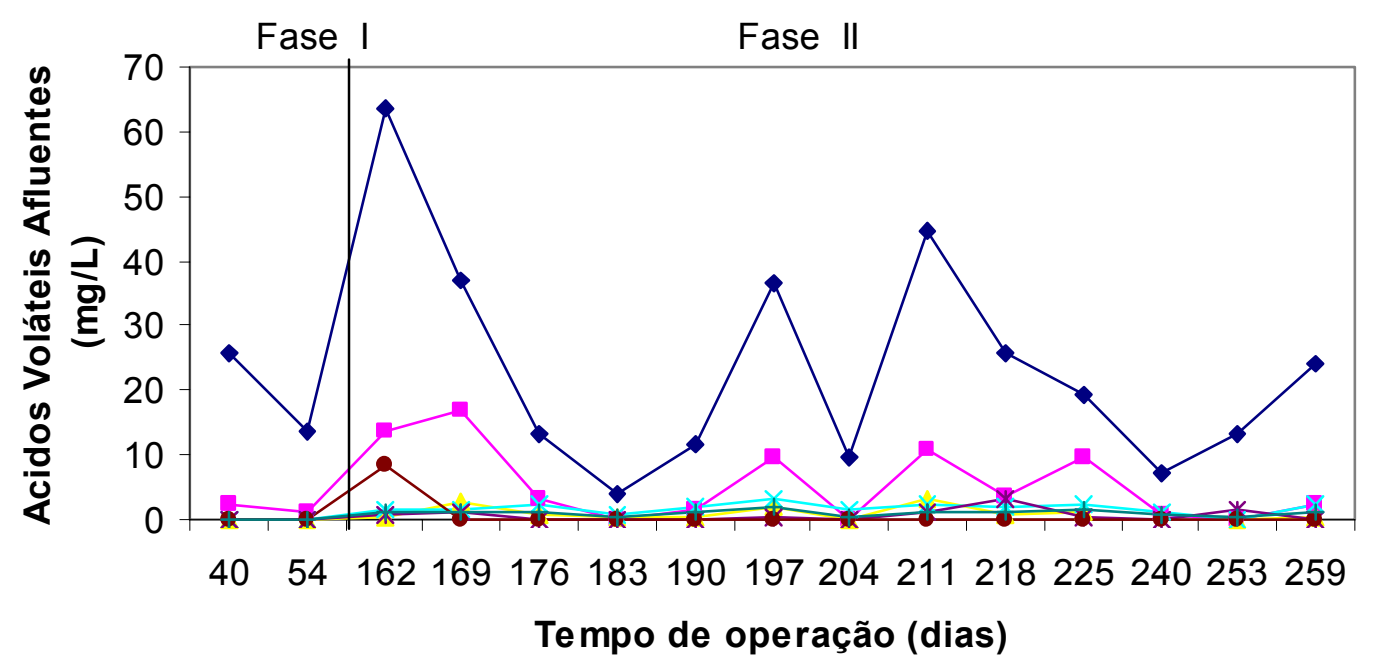

$\multimap$ Acét. $\rightarrow$ Prop. $\triangle$ But. $\rightarrow$ Isov. $\rightarrow$ Valér. $\rightarrow$ Capr. $\multimap$ Isob.

Figura 72 - Variação dos ácidos voláteis afluentes ao longo do tempo.

A Figura 73 apresenta a variação dos ácidos voláteis efluentes ao longo do tempo.

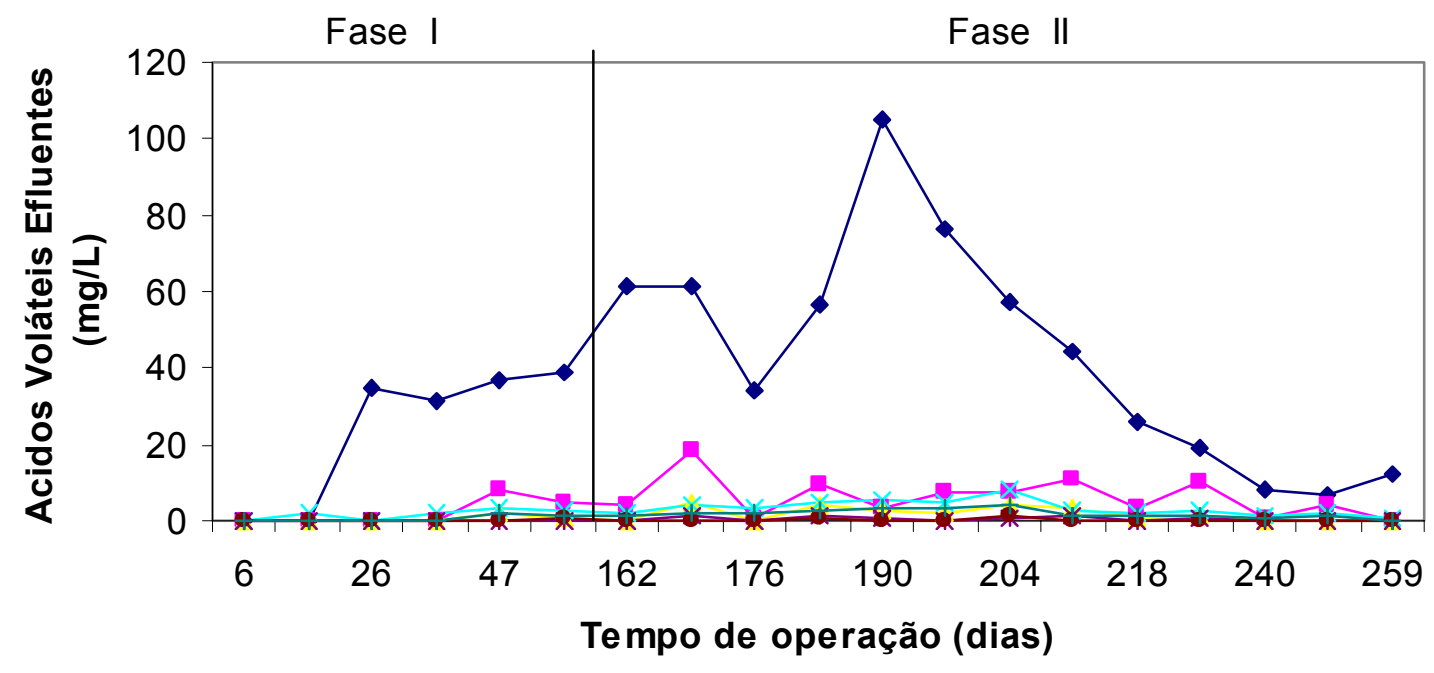

$\rightarrow$ Acét. $\rightarrow$ Prop. $\triangle$ But. $\rightarrow$ Isov. $\rightarrow$ Valér. $\rightarrow$ Capr. $\longrightarrow$ Isob.

Figura 73 - Variação dos ácidos voláteis efluentes ao longo do tempo.

\subsection{Nitrogênio}

Da Figura 74 a Figura 77 são apresentadas, respectivamente, as variações das concentrações de nitrogênio total Kjeldahl, nitrogênio amoniacal, nitratos e nitritos. De 
acordo com Chernicharo (1997), os valores de nitrogênio amoniacal devem ficar abaixo de $150 \mathrm{mg} / \mathrm{L}$ para não se tornarem tóxicos para as bactérias. Nota-se que em nenhum momento os valores foram superiores ao recomendado. A eficiência média de remoção de NTK foi baixa, apenas $15 \%$, com máxima de $40 \%$. Em relação ao nitrogênio orgânico, as eficiências de remoção foram mais significativas, com média de $50 \%$ e picos de $80 \%$. Este fato indica que houve conversão de nitrogênio orgânico em nitrogênio amoniacal, nitritos e nitratos, já que estes apresentaram maior concentração no efluente em várias coletas, embora nas médias globais observe-se pequena diminuição no efluente. As médias observadas foram de $70 \mathrm{mg} / \mathrm{L}$ para o afluente e 60 $\mathrm{mg} / \mathrm{L}$ para o efluente para nitrogênio total Kjeldahl, de $50 \mathrm{mg} / \mathrm{L}$ para o nitrogênio amoniacal no afluente e efluente; e $20 \mathrm{mg} / \mathrm{L}$ no afluente e $10 \mathrm{mg} / \mathrm{L}$ no efluente para o nitrogênio orgânico.

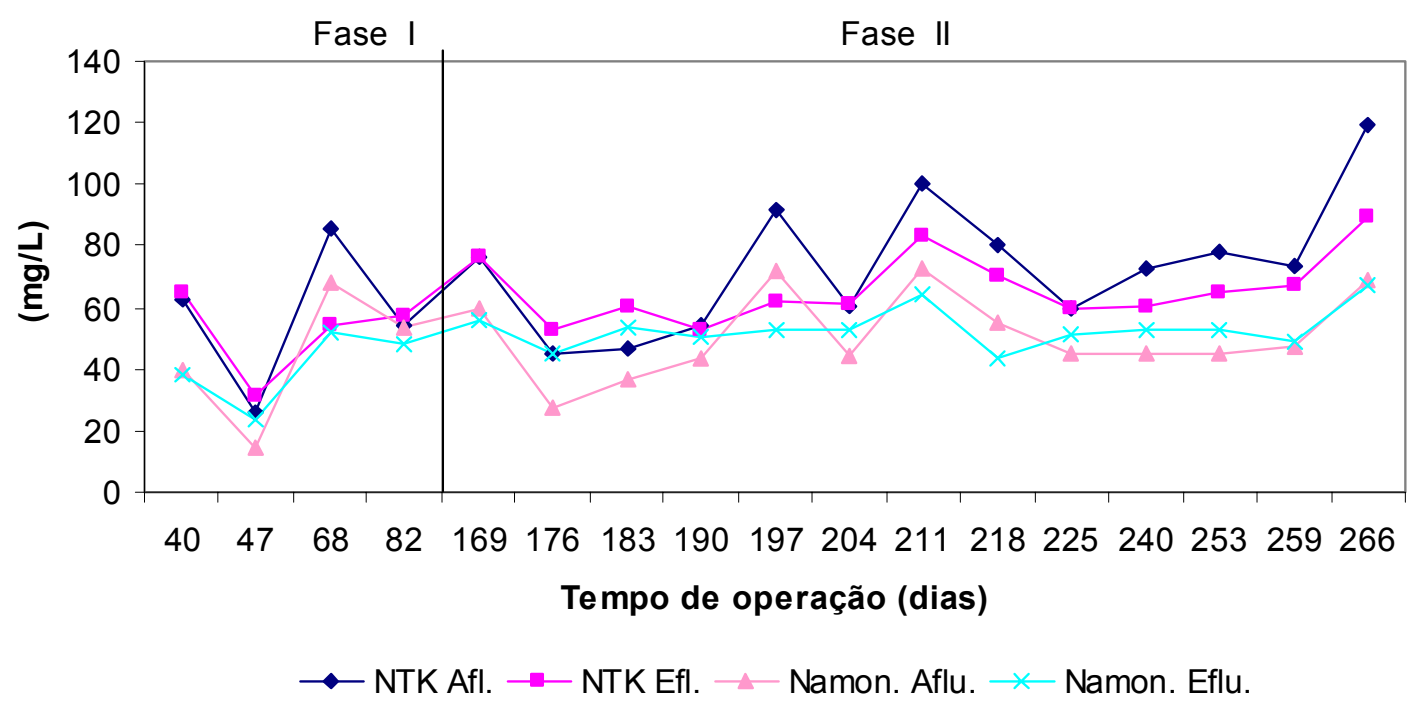

Figura 74 - Variação da concentração de nitrogênio total Kjeldahl e nitrogênio amoniacal ao longo do tempo. 


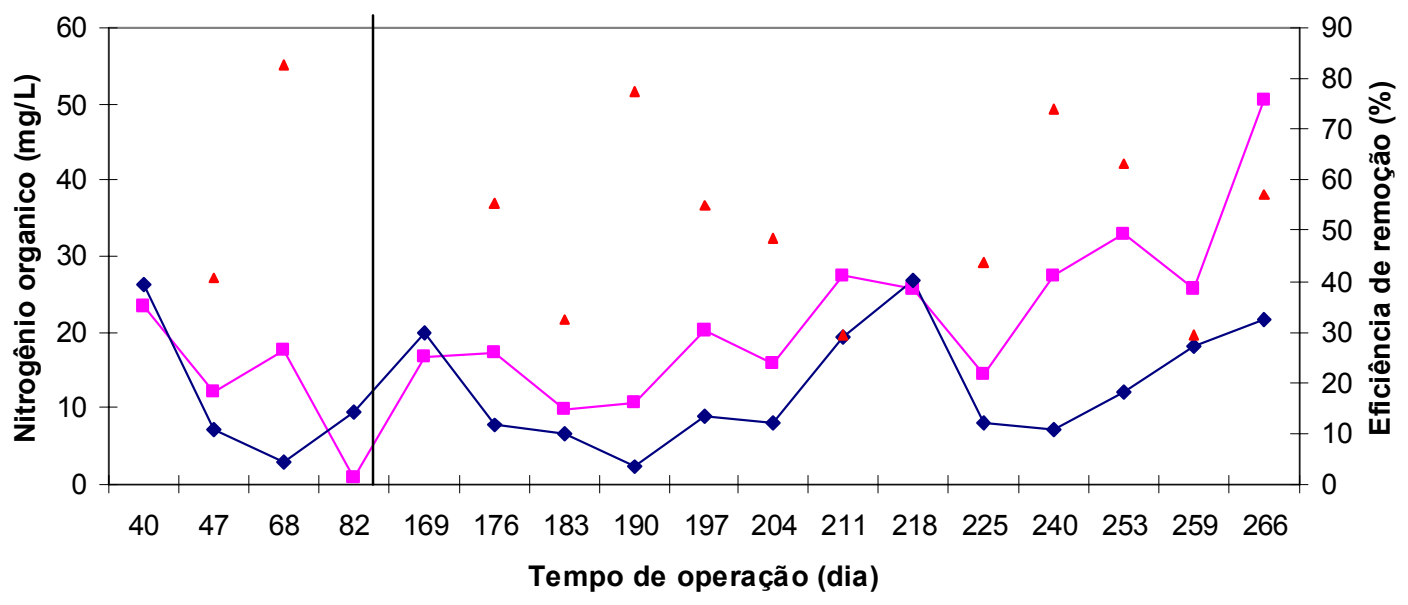

$\rightarrow$ Norg Aflu. $\rightarrow$ Norg Eflu $\triangle$ Eficência de remoção

Figura 75 - Variação da concentração de nitrogênio orgânico ao longo do tempo e eficiência de remoção.

Os altos valores de DQO afluente associados ao funcionamento ainda não satisfatório do reator UASB forneceram um afluente para o BAS ainda com altos valores médios de DQO $(400 \mathrm{mg} / \mathrm{L})$. Este fato provavelmente inibiu a nitrificação no BAS, fazendo com que no retorno do lodo deste para o UASB os valores de nitratos fossem baixos (média de $3 \mathrm{mg} / \mathrm{L}$ ). Souza et al. (2005) estudando desnitrificação em reator UASB de 7,2 L, recircularam efluente nitrificado com concentrações de 10 a $35 \mathrm{mg} / \mathrm{L}$ (de reator nitrificante) e obtiveram no UASB desnitrificação com eficiências de $65 \%$.

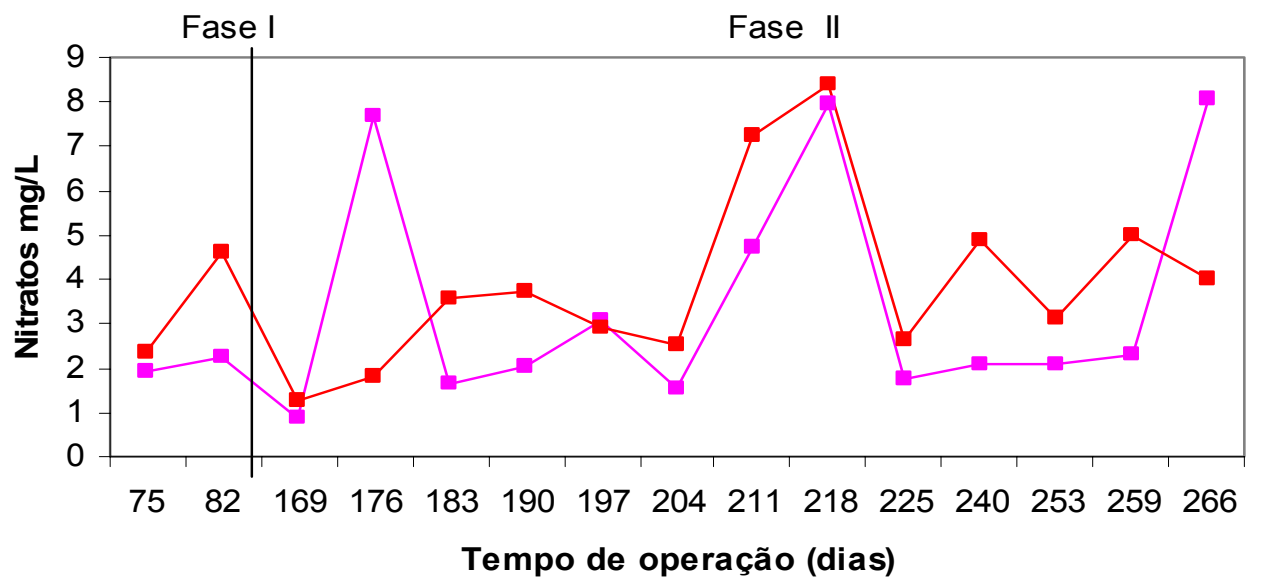

$\rightarrow$ Afl. $\rightarrow$ Efl.

Figura 76 - Variação da concentração de nitrato ao longo do tempo. 


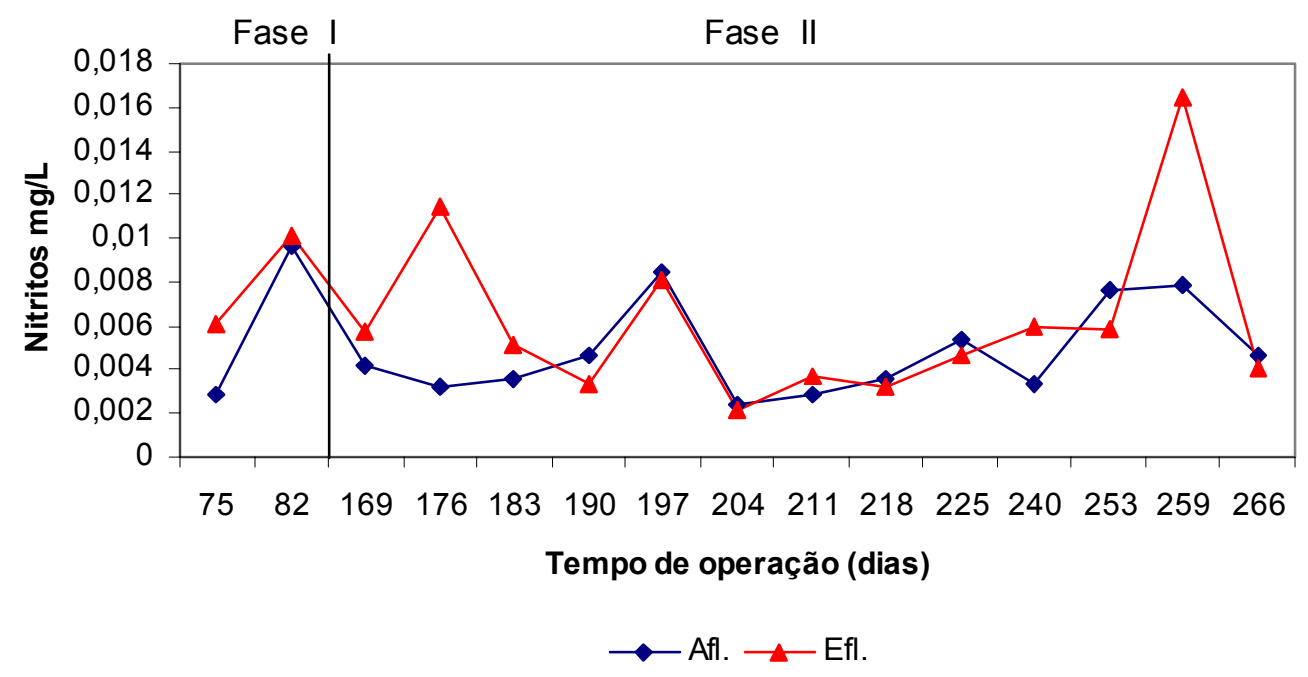

Figura 77 - Variação da concentração de nitrito ao longo do tempo.

\subsection{Fósforo Total}

Não houve variação na concentração de fósforo total entre o afluente e efluente e os valores aferidos encontram-se na tabela A16 em anexo.

Para a Fase I a relação esperada de DQO:N:P (500:5:1) foi de 200:30:1 e para a Fase II 300:40:1, mostrando que o esgoto afluente possuía nitrogênio e fósforo em quantidades superiores às esperadas em relação ao valor da DQO.

\subsection{Temperatura}

As temperaturas médias de operação foram de $23{ }^{\circ} \mathrm{C}$ no inverno e $26{ }^{\circ} \mathrm{C}$ no verão, dentro do esperado para esgotos domésticos segundo Chernicharo (1997).

\subsection{Produção de Biogás}

O sistema não dispõe de medidor de vazão de biogás gerado e o fato de na coleta do biogás, para avaliação de sua composição, notar-se que este chegava em pequenas quantidades pela tubulação de coleta, desencorajou a instalação de sistema de leitura de vazão, antes que fossem providenciadas a cobertura do reator e a perfeita vedação das tampas da câmara de gás.

De acordo com Chernicharo (1997), taxas de liberação inferiores a $1,0 \mathrm{~m}^{3} / \mathrm{m}^{2} \cdot \mathrm{h}$ dificultam a liberação do gás e favorecem a formação de densas camadas de escuma. 
Observou-se a formação de escuma bastante fina e não constante, já que em momentos de excesso de vazão essa era revolvida e novamente incorporada ao líquido. Portanto, acredita-se que realmente a produção de gás foi bem inferior à esperada $\left(9,7 \mathrm{~m}^{3} / \mathrm{m}^{2}\right.$.dia), visto que o reator ainda não estabilizou completamente e que os problemas de possíveis perdas citados anteriormente também tenham contribuído para a pequena vazão de biogás observada.

As leituras do biogás não possibilitaram que fosse feita análise de sua composição frente à magnitude dos resultados. As leituras de $\mathrm{CH}_{4}$ ficaram predominantemente abaixo do limite de detecção da curva do aparelho de leitura. Além da produção pequena e possíveis vazamentos, podem também ter ocorrido problemas relacionados ao transporte do amostrador de gás, visto que o trajeto da ETE ao laboratório durava em torno de 30 minutos, podendo ter ocorrido vazamento do material coletado e conseqüente entrada de ar, o que teria refletido a predominância de gás nitrogênio nas leituras.

\subsection{Concentração de metais}

Foram analisadas amostras do esgoto proveniente do distrito de Água Vermelha, da empresa TAM, do esgoto afluente e efluente ao UASB, BAS e UV, além das amostras coletadas ao longo da altura do UASB quanto à presença de metais pesados, para certificar-se de que não existiam compostos em concentrações prejudiciais à digestão do esgoto. Esta precaução foi tomada com base em relatos operacionais da ETE antes da reforma (ainda operando com o sistema de lagoas), quando lançamentos desta natureza provocavam sérios danos à biomassa das lagoas. As Tabela 15 e 16 mostram, respectivamente, os valores das concentrações $(\mathrm{mg} / \mathrm{L})$ de zinco, chumbo, cádmio, níquel, ferro, manganês, cobre e cromo para os pontos de coleta na ETE. Os valores de ferro em maiores concentrações em relação aos outros elementos devem-se ao solo de Água Vermelha. A análise de cianeto no sedimento da caixa de areia apresentou concentração de $0,006 \mathrm{mg} / \mathrm{L}$, abaixo do limite de $0,2 \mathrm{mg} / \mathrm{L}$ permitido pela CETESB, de acordo com o Decreto nº 8.468, de 8/9/1976, (SÃO PAULO, 1976). 
Tabela 15 - Valores das concentrações em $\mathrm{mg} / \mathrm{L}$ de metais pesados para a ETE Água Vermelha.

\begin{tabular}{|c|c|c|c|c|c|c|c|}
\hline \multirow[b]{2}{*}{ Metal } & \multicolumn{7}{|c|}{ Concentrações em mg/L } \\
\hline & $\begin{array}{l}\text { TAM } \\
\text { efluente }\end{array}$ & $\begin{array}{l}\text { A.V. } \\
\text { efluente }\end{array}$ & $\begin{array}{l}\text { UASB } \\
\text { afluente }\end{array}$ & $\begin{array}{l}\text { UASB } \\
\text { efluente }\end{array}$ & $\begin{array}{l}\text { BAS } \\
\text { afluente }\end{array}$ & $\begin{array}{l}\text { BAS } \\
\text { efluente }\end{array}$ & $\begin{array}{l}\text { UV } \\
\text { afluente }\end{array}$ \\
\hline $\mathrm{Zn}$ & 0,64 & 0,06 & 0,17 & 1,47 & 0,16 & 0,12 & 1,57 \\
\hline $\mathrm{Pb}$ & ND & ND & ND & ND & ND & ND & ND \\
\hline $\mathrm{Cd}$ & ND & ND & ND & ND & ND & ND & ND \\
\hline $\mathrm{Ni}$ & ND & ND & 0,23 & ND & ND & ND & ND \\
\hline $\mathrm{Fe}$ & 1,20 & 2,43 & 12,54 & 2,60 & 1,63 & 2,61 & 19,96 \\
\hline $\mathrm{Mn}$ & 0,02 & 0,01 & 0,08 & 0,04 & 0,05 & 0,43 & 0,47 \\
\hline $\mathrm{Cu}$ & ND & ND & 0,01 & 0,03 & ND & ND & 0,06 \\
\hline $\mathrm{Cr}$ & ND & ND & 0,52 & ND & ND & 0,10 & ND \\
\hline
\end{tabular}

ND: não detectado.

A.V.: Efluente proveniente do distrito de Água Vermelha.

Tabela 16 - Valores das concentrações em $\mathrm{mg} / \mathrm{L}$ de metais pesados para o perfil do reator UASB.

\begin{tabular}{llllllll}
\hline \multirow{2}{*}{ Metal } & \multicolumn{7}{l}{ Concentrações em mg/L } \\
\cline { 2 - 8 } & $0,25 \mathrm{~m}$ & $0,85 \mathrm{~m}$ & $1,45 \mathrm{~m}$ & $2,05 \mathrm{~m}$ & $2,65 \mathrm{~m}$ & $3,25 \mathrm{~m}$ & $3,85 \mathrm{~m}$ \\
\hline $\mathrm{Zn}$ & 0,27 & 0,29 & 0,24 & 0,20 & 0,23 & 0,19 & 0,20 \\
$\mathrm{~Pb}$ & $\mathrm{ND}$ & $\mathrm{ND}$ & $\mathrm{ND}$ & $\mathrm{ND}$ & $\mathrm{ND}$ & $\mathrm{ND}$ & $\mathrm{ND}$ \\
$\mathrm{Cd}$ & $\mathrm{ND}$ & $\mathrm{ND}$ & $\mathrm{ND}$ & $\mathrm{ND}$ & $\mathrm{ND}$ & $\mathrm{ND}$ & $\mathrm{ND}$ \\
$\mathrm{Ni}$ & $\mathrm{ND}$ & $\mathrm{ND}$ & $\mathrm{ND}$ & $\mathrm{ND}$ & $\mathrm{ND}$ & $\mathrm{ND}$ & $\mathrm{ND}$ \\
$\mathrm{Fe}$ & 8,12 & 9,11 & 5,42 & 9,48 & 6,72 & 6,34 & 4,64 \\
$\mathrm{Mn}$ & 0,06 & 0,08 & 0,04 & 0,04 & 0,05 & 0,06 & 0,05 \\
$\mathrm{Cu}$ & 0,06 & 0,08 & 0,06 & $\mathrm{ND}$ & $\mathrm{ND}$ & $\mathrm{ND}$ & $\mathrm{ND}$ \\
$\mathrm{Cr}$ & $\mathrm{ND}$ & $\mathrm{ND}$ & $\mathrm{ND}$ & 0,03 & $\mathrm{ND}$ & $\mathrm{ND}$ & $\mathrm{ND}$ \\
\hline
\end{tabular}

ND: não detectado.

A análise da toxicidade por metais pesados foi feita através do parâmetro $\mathrm{K}$ (meq/kg) de Mosey* (1975) apud Foresti (2005). Segundo este autor, para valores inferiores a $200 \mathrm{meq} / \mathrm{kg}$ tem-se inibição pouco provável em processos anaeróbios de tratamento. Os valores calculados pela eq. (15) encontram-se na Tabela 17.

${ }^{*}$ Mosey, F.E.. (1975). Water pollution control. 


$$
K(\mathrm{meq} / \mathrm{kg})=\frac{\frac{Z n}{32,7}+\frac{N i}{29,4}+\frac{P b}{103,6}+\frac{C d}{56,2}+\frac{067 C u}{31,8}}{S T}
$$

Onde: $\mathrm{Zn}, \mathrm{Ni}, \mathrm{Pb}, \mathrm{Cd}$ e $\mathrm{Cu}$ são as concentrações destes metais em mg/L;

0,67 é o fator de redução parcial do cobre ao estado cuproso;

$\mathrm{ST}$ a concentração de sólidos totais em $\mathrm{kg} / \mathrm{L}$.

Tabela 17 - Valores do parâmetro K de Mosey para o reator UASB.

\begin{tabular}{ll}
\hline Entrada UASB & 28,39 \\
\hline $0,25 \mathrm{~m}$ & 17,24 \\
$0,85 \mathrm{~m}$ & 22,74 \\
$1,45 \mathrm{~m}$ & 20,08 \\
$2,05 \mathrm{~m}$ & 14,45 \\
$2,65 \mathrm{~m}$ & 14,85 \\
$3,25 \mathrm{~m}$ & 12,70 \\
$3,85 \mathrm{~m}$ & 12,53 \\
Saída UASB & 96,26 \\
\hline
\end{tabular}

\subsection{Eficiência global da ETE Água Vermelha}

A ETE Água Vermelha, apesar dos fatores intervenientes, tem apresentado boas eficiências de remoção a partir do mês de julho (quatro meses após a partida do reator UASB e três meses após a partida do biofiltro e do reator de desinfecção por UV). Em dezembro de 2006 sua eficiência atingiu 90 \%. A tabela 18 apresenta as médias mensais de eficiências de remoção de DBO, gentilmente fornecidas pelo SAAE - São Carlos, desde o início de operação da ETE em fevereiro até dezembro de 2006.

Tabela 18 - Eficiências globais de remoção em \% da ETE Água Vermelha em função das análises de DBO afluente e efluente.

\begin{tabular}{llll}
\hline Mês & $\begin{array}{l}\text { Afluente } \\
(\mathrm{DBO} \text { em mg/L) }\end{array}$ & $\begin{array}{l}\text { Efluente } \\
(\mathrm{DBO} \text { em mg/L) }\end{array}$ & Eficiência de remoção (\%) \\
\hline Fevereiro & 155 & 65 & 58 \\
Março & 115 & 83 & 28 \\
Abril & 401 & 257 & 36 \\
Maio & 343 & 388 & - \\
\hline
\end{tabular}


Tabela 18 - Eficiências globais de remoção em \% da ETE Água Vermelha em função das análises de DBO afluente e efluente.

\begin{tabular}{llll}
\hline Junho & 350 & 298 & 15 \\
Julho & 380 & 148 & 61 \\
Agosto & 425 & 170 & 60 \\
Setembro & 401 & 128 & 68 \\
Outubro & 358 & 86 & 76 \\
Novembro & 336 & 60 & 82 \\
Dezembro & 394 & 39 & 90 \\
\hline
\end{tabular}

Fonte: SAAE - São Carlos.

As baixas eficiências observadas nos meses de maio e junho correspondem ao período em que foram realizadas intervenções nas unidades de tratamento, como a instalação do by-pass.

Ressalta-se que o reator UASB esteve submetido, além da situação de sobrecarga hidráulica, aos lançamentos de lodos de fossas e ao retorno de lodo do BAS, devendo estes fatores ser levados em consideração na avaliação da eficiência obtida. 


\section{CONCLUSÕES E RECOMENDAÇÕES}

\subsection{Relato operacional}

Concluiu-se que o sistema de gradeamento não teve o desempenho esperado por ter sido instalado de maneira incorreta. Observando-se a figura 4, nota-se a presença de uma barra transversal onde a grade deveria estar apoiada, ao contrário do que foi executado, onde a grade está posicionada abaixo desta, impossibilitando que seja rotacionada para facilitar sua limpeza. Isto torna necessário que o operador entre na caixa de areia e remova com pá o material retido, operação que oferece risco de contaminação pelo contato direto com o esgoto.

No projeto inicial existiam também cestos coletores instalados na caixa de entrada do reator UASB, com a função de reter sólidos grandes que porventura persistissem após o tratamento preliminar (Figura 78). Estes cestos chegaram a ser instalados no reator, mas foram furtados durante a execução da obra. Sugere-se que estes sejam novamente providenciados ou que, como foi feita na ETE de Caxias do Sul (EKMAN et al., 2000), seja providenciada a instalação sobre a grade de entrada de uma lâmina de aço inox, nas dimensões da grade, com furos de diâmetro inferior ao espaçamento das grades, dotada de alça e calha deslizadora na lateral que facilite sua limpeza. Isto impediria que os sólidos de grande dimensão atinjam o reator UASB, prejudicando seu desempenho. 


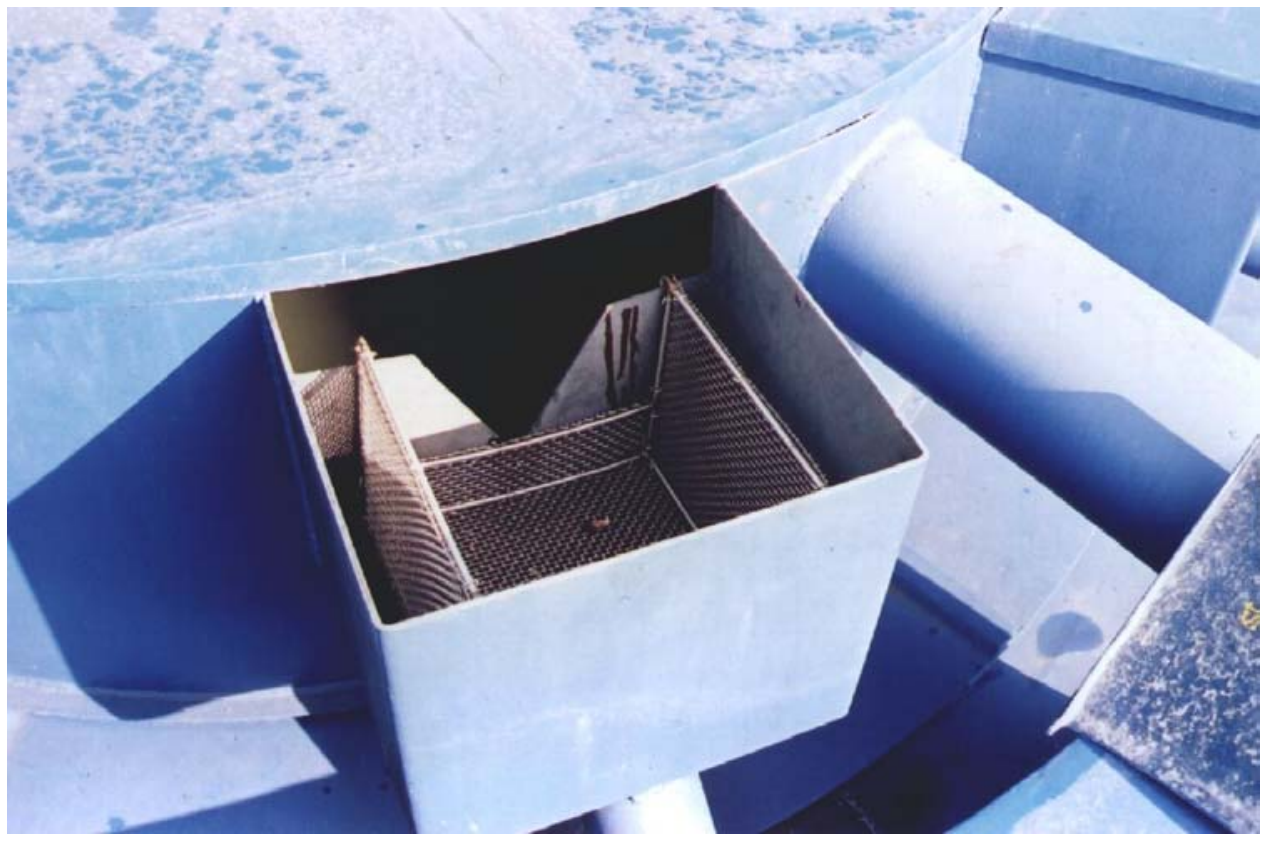

Figura 78 - Cesto instalado na caixa distribuidora de vazão do reator UASB.

No acompanhamento do funcionamento da caixa de areia, observou-se a presença de um sedimento de coloração negra, que fez necessária a limpeza desta unidade três vezes por semana e que provavelmente foi responsável pela queima da bomba por duas vezes. Este sedimento provavelmente vinha do distrito de Água Vermelha, pois se acumulava logo após a entrada deste na caixa anterior à comporta, (mostrada na figura 2) e pode ser proveniente de lançamento de efluente industrial ou ainda dos lançamentos das fossas, pois, como dito anteriormente, estas sofriam infiltração de água pluvial, quando provavelmente sedimentos eram carreados para seu interior.

No projeto, esta unidade, dividida em dois compartimentos, deveria ser utilizada em apenas metade de seu volume, permanecendo o outro compartimento fechado para ser utilizado apenas nos momentos de limpeza. No entanto, desde o início da operação da ETE foi necessária a utilização das duas câmaras, pois nos momentos de pico de vazão se observava excessivo aumento na altura da lâmina e na velocidade com que o líquido escoava pela caixa, o que prejudicava a sedimentação de sólidos em suspensão.

A estação elevatória instalada, como relatado anteriormente, possui volume inferior ao de projeto, o que implicou em possuir cota de fundo acima da estabelecida neste. Este fato faz com que o esgoto em excesso na elevatória que é encaminhado por uma tubulação extravasora para o tanque pulmão, permaneça neste último até que um registro de fundo seja manualmente operado e o esgoto possa retornar, pois o refluxo 
por gravidade não ocorre devido ao desnível. O acúmulo favorece a formação de algas no tanque pulmão que acabam por atingir o reator UASB, interferindo em seu funcionamento, como previamente citado. Sugere-se, portanto, que a cota de fundo do tanque pulmão seja elevada, permitindo o retorno do esgoto para a elevatória por gravidade e este tanque funcione então como tanque de equalização.

O menor volume da elevatória também ocasionou maior número de acionamentos da bomba, o que refletiu diretamente no desempenho do BAS, pois a vazão acumulada nas caixas de distribuição deste reator não escoava completamente através dos vertedores de entrada antes que a bomba fosse novamente acionada, provocando entrada de esgoto não tratado diretamente nas tulipas coletoras de efluente final.

De acordo com a vazão aferida no reator UASB, acredita-se que a bomba instalada não corresponde à especificada em projeto. Para sua adequação à condição atual de volume disponível na EE, recomenda-se a instalação de uma bomba de capacidade aproximada de recalque de $4 \mathrm{~L} / \mathrm{s}$ e a utilização do tanque pulmão como tanque de equalização.

No reator UASB recomenda-se a instalação de medidor de vazão para que se tenha medida precisa da vazão afluente, visto que parte da vazão armazenada no tanque pulmão é recalcada para o reator nos momentos em que a vazão afluente à ETE diminui, fazendo com que a vazão no reator durante o dia seja maior que a afluente à ETE, medida na calha Parshall da caixa de areia. Recomenda-se também a cobertura do reator para redução de perda do biogás formado e redução dos odores produzidos. Estes dois itens constavam no estudo preliminar da ETE, mas necessitaram ser suprimidos devido a limitações orçamentárias. Acredita-se que este seja um investimento importante para o bom funcionamento da ETE no futuro.

A ETE de Água Vermelha, como a grande maioria das ETEs em operação no país, está sujeita a fatores de interferência que afetam seu bom funcionamento, como os de natureza hidráulica, que podem estar relacionados ao desconhecimento das vazões afluentes, podendo estas deverem-se a vazões industriais, além de lançamentos indevidos de lodos de caminhões limpa-fossa que acontecem na rede coletora. 


\subsection{Conclusões}

Os resultados mostraram um aumento nas concentrações efluentes do UASB em termos de sólidos dissolvidos e matéria orgânica dissolvida, quando submetido ao lançamento de lodo de fossas, que afetaram significativamente o afluente do BAS.

O leito de lodo formado na Fase I e na Fase II possuía concentrações semelhantes de sólidos, porém o segundo apresentou melhores remoções de matéria orgânica afluente.

Na Fase I o reator não foi capaz de remover matéria orgânica, não ocorrendo formação da manta de lodo. Na Fase II ocorreu o provável início da estabilização do processo, aproximadamente 60 dias após a inoculação (dia 240 de operação). A partir deste momento a remoção de matéria orgânica dissolvida foi considerada constante e foi observada a formação da manta de lodo.

As altas velocidades ascensionais prejudicaram o desempenho do reator. O bypass não foi alternativa eficiente para o controle da vazão recalcada.

O retorno de lodo aeróbio não interferiu na localização no reator da população metanogênica, que foi encontrada em maior quantidade a $0,25 \mathrm{~m}$ de altura; tampouco na sedimentabilidade do lodo misto (anaeróbio/aeróbio), que foi de 65\% (STV/ST).

O protocolo de descarte de $8,5 \mathrm{~m}^{3}$ pode ser executado a cada 30 dias.

\subsection{Propostas para futuras pesquisas}

a) Continuidade da avaliação da influência do retorno semanal de lodo aeróbio nas populações microbianas do leito e da manta do reator através de ensaios de atividade metanogênica específica e microscopia, sem a interferência do lançamento de lodo de fossas e da velocidade ascensional excessiva. Isso possibilitaria concluir se o protocolo de descarte semanal realmente tem efeitos diferentes dos observados nos trabalhos com descartes diários.

b) Continuação da investigação da produção de sólidos por mais tempo, com o reator operando em estabilidade, para que se conheça o Yobs nesta condição. Isto tornaria possível avaliar se a produção de sólidos é realmente superior à observada na literatura ou se esta conclusão esteve ligada somente à instabilidade inerente ao reator no período de partida. 
c) Continuidade da comparação entre outros dias da semana, além de segundas e terças-feiras, da DQO afluente e efluente à ETE, para que se possa confirmar o comportamento obseravado entre segundas e terças-feiras. 


\section{REFERÊNCIAS BIBLIOGRÁFICAS}

ALÉM SOBRINHO, P. \& JORDÃO, E. P. (2001). Pós-tratamento de efluentes de reatores anaeróbios - uma análise crítica. In: CHERNICHARO, C.A.L. (coord.). Pós-tratamento de efluentes de reatores anaeróbios. Belo Horizonte: Projeto PROSAB. pp. 491-513.

APHA, AWWA; WPCF. (1999). Standard methods for examination of water and wastewater. $20^{\text {th }}$ ed. Washington DC (USA): American Public Health Association, American Water Works Association, Water Pollution Control Federation.

ARAÚJO, J.C. (1995) Caracterização e evolução de biofilme em reator anaeróbio de leito fluidificado alimentado com esgoto sanitário sintético. Dissertação (Mestrado). São Carlos: Escola de Engenharia de São Carlos da Universidade de São Paulo EESC/USP. 158p.

BERK, S.G.; SON, J.H.G. (1993). Wastewater Organisms - A Color Atlas. Boca Raton: Lewis Publishers. 82p.

BLACK, J. G. (2002). Características das células procarióticas e eucarióticas. In:__. Microbiologia: fundamentos e perspectivas. $4^{\mathrm{a}}$ ed. Cap. 4. Rio de Janeiro: Guanabara Koogan. 
CARRASCO, K. I. A. (1992) Balanço de massa e energia: aplicação ao tratamento de esgotos sanitários com reatores anaeróbios de manta de lodo (UASB) à temperatura de $20^{\circ} \mathrm{C}$. Dissertação (Mestrado). São Carlos: Escola de Engenharia de São Carlos da Universidade de São Paulo - EESC/USP. 212 p.

CARVALHO, K. Q.; SALGADO, M. T.; PIRES, E. P. (2005). Influência da variação cíclica de carga hidráulica no comportamento do reator UASB. In: Anais do $23^{\circ}$ CONGRESSO BRASILEIRO DE ENGENHARIA SANITÁRIA E AMBIENTAL. Campo Grande - MS. CD-ROM.

CHERNICHARO, C.A.L. (1997). Reatores Anaeróbios. Coleção "Princípios do tratamento biológico de águas residuárias”, volume 5. Belo Horizonte: Depto. de Eng. Sanitária e Ambiental (DESA), UFMG. 246 p.

CHERNICHARO, C.A.L. \& BORGES, J.M. (1996) Metodologia utilizada durante a partida de um reator UASB de $477 \mathrm{~m}^{3}$ tratando esgotos tipicamente domésticos. In: ANAIS DO XXV CONGRESSO INTERAMERICANO DE INGENIERIA SANITARIA Y AMBIENTAL, Tomo I - Vol. 2, pp. 655-661, México, DF.

CHERNICHARO, C.A.L.; van HAANDEL, A. C.; FORESTI, E.; CYBIS, L. F. (2001). Introdução. In: CHERNICHARO, C.A.L. (coord.). Pós-tratamento de efluentes de reatores anaeróbios. Belo Horizonte: Projeto PROSAB. pp. 491-513.

COSENTINO, P.R.S.; FILHO, J.A.S.; van HAANDEL, A.C.; CAVALCANTI, P.F.F. (2005). Estabilização de lodo de sistemas aeróbios em reatores tipo UASB. In: Anais do $23^{\circ}$ CONGRESSO BRASILEIRO DE ENGENHARIA SANITÁRIA E AMBIENTAL. Campo Grande - MS. CD-ROM.

D'HAINAUT, L. (1997) Conceitos e métodos da estatística. 2a ed. vol. 1. Lisboa: FUNDAÇÃO CALOUSTE GULBENKIAN, 362 p. 
EKMAN, M. C. S.; PAlOSCHI, R. S. P.; SOUZA, J. F. (2000). Avaliação do desempenho da partida de um reator UASB operando em condições climáticas desfavoráveis. In: Anais do XXVII Congresso Interamericano de Engenharia Sanitária e Ambiental, Fortaleza. CD-ROM.

FORESTI, E. (2005). Toxicidade em processos anaeróbios. São Carlos: Escola de Engenharia de São Carlos da Universidade de São Paulo - EESC/USP. (notas de aula).

FORESTI, E.; FLORÊNCIO, L.; Van HAANDEL; ZAIAT, M.; CAVALCANTI, P.F.F. (1999). Fundamentos do tratamento anaeróbio. In: CAMPOS, J.R. (coord). Tratamento de esgotos sanitários por processo anaeróbio e disposição controlada no solo. Rio de Janeiro: ABES. Cap 2.

GOMES, M.R. \& CHERNICHARO, C.A.L. (2005) Experiência operacional e análise de desempenho do sistema de tratamento de esgotos de Bonito - MS. In: $23^{\circ}$ CONGRESSO BRASILEIRO DE ENGENHARIA SANITÁRIA E AMBIENTAL. Campo Grande - MS. CD-ROM.

GONÇALVES, R. F.; ARAÚJO, V. L.; CHERNICHARO, C.A.L. (1998). Association of a UASB reactor and a submerged aerated biofilter for domestic sewage treatment. Water Science and Technology. v.38, n. 8-9, pp.189-195.

HIRATA, Y. S. (2002). Gráficos de controle para laboratórios de ensaios. Biológico. São Paulo, v. 64, n. 2, pp.183-185, jul./dez.

JENKINS, D.; RICHARD, M.G.; DORIGGER, G.T. (1993). Manual on the causes and control of activated sludge bulking, foaming and other solids separation problems. Lewis Publishers, $3^{\mathrm{a}}$ ed. $272 \mathrm{p}$.

JORDÃO, E. P. \& PESSÔA, C. A. (2005) Tratamento de esgotos domésticos. $4^{\mathrm{a}}$ ed. Rio de Janeiro: SEGRAC. 935 p. 
KELlNER, E. (2003). Projeto Básico para Ampliação e Reforma da ETE de Água Vermelha. Projeto. 105 p.

LEITÃO, R.C.; LOPES, A.C.; van HAANDEL; A.C.; ZEEMAN, G.; LETTINGA, G. Expansilbilidade da manta de lodo de reatores UASB. In: Anais do $23^{\circ}$ CONGRESSO BRASILEIRO DE ENGENHARIA SANITÁRIA E AMBIENTAL. Campo Grande - MS. CD-ROM.

MacLEOD, F.A.; GUIOT, S.R.; COSTERTON, J.W. (1990). Layered structure of bacterial aggregates produced in upflow anaerobic slugde bed and filter reactor. Applied and Environmental Microbiology, v.56, n.6, pp.1598-1607.

MAHMOUND, N.; ZEEMAN, G.; GIJZEN, H.; LETTINGA, G. (2003). Solids removal in upflow anaerobic reactors, a review. Bioresource Technology, v. 90, pp. $1-9$.

METCALF \& EDDY. Inc. (2003). Wastewater Engineering: Treatment, Disposal, Reuse. $4^{\mathrm{a}}$ ed. New York: McGraw - Hill Book. 1815 p.

MORAES, E.M., ADORNO, M.A.T., ZAIAT, M. (2000). Determinação de Ácidos Voláteis por Cromatografia Gasosa em Efluentes de Reatores Anaeróbios Tratando Resíduos Líquidos e Sólidos. Anais da VI Oficina e Seminário Latino-Americano de Digestão Anaeróbia. Vol. II. pp. 235-238. Recife, PE: Editora Universitária da UFPE.

NATION, J. L. (1983) A new method using hexamethyldisilazane for preparation of soft tissues for scanning electron microscopy. Stain Tecnology. Vol. 58. pp. 347351.

OLIVA, L.C.H.V. (1997). Tratamento de esgotos sanitários com reator anaeróbio de manta de lodo (UASB) protótipo: desempenho e respostas às sobrecargas 
hidráulicas. Tese (Doutorado). São Carlos: Escola de Engenharia de São Carlos da Universidade de São Paulo - EESC/USP. 218p. + anexos.

OLIVEIRA, S.M.A.C.; VON SPERLING, M. (2005). Avaliação de 166 ETEs em operação no país, compreendendo diversas tecnologias. Parte 1: Análise de desempenho. Engenharia Sanitária e Ambiental (ABES). Vol. 10. n. 2, abr-jun, pp. $152-161$.

PAULA JUNIOR, D.R.P.; MORAES, L.M.; CHERNICHARO, C.A.L.; PONTES, P.P.; CASSINI, S.T.; GONÇALVES, R.F.; FILHO, P.B.; SOARES, H.M. (2003). Estabilização anaeróbia de lodos. In: CASSINI, S.T. (coord.). Digestão de resíduos sólidos orgânicos e aproveitamento do biogás. Rio de Janeiro: ABES, RIMA. Cap. 3.

PENNA, J. A. (1994). Estudo da metodologia do teste de atividade metanogênica especifica. Tese (Doutorado). São Carlos: Escola de Engenharia de São Carlos da Universidade de São Paulo - EESC/USP. 227p + anexos.

PONTES, P.P. \& CHERNICHARO, C.A.L. (2005) Efeito do retorno de lodo aeróbio sobre as características da biomassa em um reator UASB em escala de demonstração utilizado para tratamento de esgoto sanitário. In: Anais do $23^{\circ}$ CONGRESSO BRASILEIRO DE ENGENHARIA SANITÁRIA E AMBIENTAL. Campo Grande - MS. CD-ROM.

PONTES, P.P. CHERNICHARO, C.A.L., MIRANDA, J.B.A., OLIVEIRA, R.M. (2004) Biomass characterization in UASB reactors used for combined treatment of domestic sewage and excess aerobic sludge produced in trickling filters. In: WORLD CONGRESS ON ANAEROBIC DIGESTION, 10, 2004, Montreal: I.W.A. Vol. 2. pp. 845-850.

PORTO, R. M. (2004). Hidráulica Básica. $3^{\text {a }}$ ed. São Carlos: EESC-USP. 540 p. 
RENNÓ, C.R.A. \& d'ÁVILA, L.R.C. (2005). Estudo hidráulico de reator anaeróbio de manta de lodo - o caso da ETE Santana em Varginha - MG. In: $23^{\circ}$ CONGRESSO BRASILEIRO DE ENGENHARIA SANITÁRIA E AMBIENTAL. Campo Grande MS. CD-ROM.

RISSOLI, C.A.; BERNARDES, R.S. (2005) Estudo de parâmetros cinéticos do reator UASB tratando esgoto doméstico e avaliação biodegradabilidade de seu efluente. In: $23^{\circ}$ CONGRESSO BRASILEIRO DE ENGENHARIA SANITÁRIA E AMBIENTAL. Campo Grande - MS. CD-ROM.

SAKAMOTO, I. K.; SARTI, A.; PASSIG, F. H.; FORESTI, E.; CAMPOS, J. R.; ZAIAT, M.; VARESCHE, M. B. (2005). Avaliação da comunidade microbiana do domínio Bacteria e Archaea em reatores anaeróbios tratando esgoto sanitário. In: Anais do IV SEMINÁRIO DO PROJETO TEMÁTICO, DESENVOLVIMENTO, ANÁLISE, APRIMORAMENTO E OTIMIZAÇÃO DE REATORES ANAERÓBIOS PARA TRATAMENTO DE ÁGUAS RESIDUÁRIAS. São Carlos: EESC/USP. pp. 336-345.

SANEVIX ENGENHARIA LTDA. (2003). Manual de operação de ETEs do tipo $U A S B+B F S$. Vitória (ES). Paginação irregular.

SÃO PAULO (Estado) (1976). Decreto $n^{\circ}$ 8.468, de 8 de setembro de 1976. Dispõe sobre a classificação das águas interiores situadas no Território do Estado de São Paulo. Diário Oficial do Estado, S. Paulo, pp. 4-18.

SILVA, A.L.B.; ANDRADE, M.C.F.E.; LOUZADA, A.G.; CASSINI, S.T.A.; GONÇALVES, R.F. (2005). Comportamento da biomassa metanogênica de lodo de reator UASB tratando esgoto sanitário e lodo de descarte de biofiltros aerados submersos. In: $23^{\circ}$ CONGRESSO BRASILEIRO DE ENGENHARIA SANITÁRIA E AMBIENTAL. Campo Grande - MS. CD-ROM.

SILVA, G.M.; GONÇALVES, R.F. (2005) Desempenho de um sistema UASB + Filtro Biológico Percolador sem etapa de decantação tratando esgoto sanitário. In: $23^{\circ}$ 
CONGRESSO BRASILEIRO DE ENGENHARIA SANITÁRIA E AMBIENTAL. Campo Grande - MS. CD-ROM.

SINGH, K.S. \& VIRARAGHAVAN, T. (2003). Impact of temperature on performance, microbiological, and hydrodynamic aspects of UASB reactors treating municipal wastewater. Water Science and Technology. v. 48, n. 6, pp. 211-217.

SMITH, K. (2006). Methanosaeta thermophila PT. Department of Genetics and Biochemistry, Clemson University. Disponível em: $<$ http://genome.jgipsf.org/finished_microbes/metth/metth.home.html>. Acesso em: 14 jan. 2007.

SOUZA, J.T.; SANTOS, K.D.; COSTA, M.J.C.; COSTA, P.L.F.; MOTA, M.F. (2005) Avaliação do desempenho do reator UASB na desnitrificação de águas residuárias domésticas. In: $23^{\circ}$ CONGRESSO BRASILEIRO DE ENGENHARIA SANITÁRIA E AMBIENTAL. Campo Grande - MS. CD-ROM.

SPEECE, R. E. (1996). Bicarbonate Alkalinity. In: Anaerobic biotechnology for industrial wastewaters. Nashville, Tenn. : Archae Press. pp. 183-219.

VALLEJOS, M. E. H. (1997). Operação e monitoramento do desempenho de reator anaeróbio de manta de lodo (UASB), tratando esgotos sanitários. Dissertação (Mestrado). São Carlos: Escola de Engenharia de São Carlos da Universidade de São Paulo - EESC/USP. 114p.

VERONEZ, F. M. (2001). Desempenho de um reator UASB tratando esgoto sanitário e realizando concomitantemente o adensamento e a digestão do lodo de descarte de biofiltros aerados submersos. Dissertação (Mestrado). Vitória: Universidade Federal do Espírito Santo. 118p.

VERSIANI, B.M.; JORDÃO, E.P.; VOLSCHAN JÚNIOR, I.; DEZOTTI, M.W.C.; AZEVEDO, J.P.S. (2005). Fatores Intervenientes no desempenho de um reator UASB submetido a diferentes condições operacionais. In: $23^{\circ}$ CONGRESSO BRASILEIRO DE ENGENHARIA SANITÁRIA E AMBIENTAL. Campo Grande MS. CD-ROM. 
VIEIRA, W.L.P.B; CARVALHO, E.H; CAMPOS, L.C. (2005). Desempenho do reator UASB da ETE Lages - Aparecida de Goiânia em sua fase inicial de operação. In: $23^{\circ}$ CONGRESSO BRASILEIRO DE ENGENHARIA SANITÁRIA E AMBIENTAL. Campo Grande - MS. CD-ROM. 
ANEXO A - Valores dos parâmetros físico-químicos. 
Tabela A1 - Valores das concentrações de sólidos totais, sólidos totais fixos e sólidos totais voláteis afluentes e efluentes $(\mathrm{mg} / \mathrm{L})$.

\begin{tabular}{|c|r|r|r|r|r|r|r|}
\hline Data & \multicolumn{1}{c|}{ Dia } & \multicolumn{1}{c|}{ STa } & \multicolumn{1}{c|}{ STe } & \multicolumn{1}{c|}{ STFa } & \multicolumn{1}{c|}{ STFe } & \multicolumn{1}{c|}{ STVa } & STVe \\
\hline $15 / 2 / 2006$ & 6 & 1.497 & 673 & & & & \\
\hline $21 / 2 / 2003$ & 12 & 285 & 990 & 29 & 180 & 256 & 810 \\
\hline $6 / 3 / 2006$ & 33 & 546 & 732 & & & & \\
\hline $29 / 3 / 2006$ & 54 & 470 & 484 & 183 & 168 & 288 & 316 \\
\hline $10 / 4 / 2006$ & 68 & 865 & 897 & 163 & 301 & 702 & 596 \\
\hline $26 / 4 / 2004$ & 82 & 583 & 1.006 & & & & \\
\hline $18 / 7 / 2006$ & 162 & 417 & 443 & 225 & 75 & 192 & 368 \\
\hline $2 / 8 / 2006$ & 176 & 506 & 645 & 93 & 155 & 414 & 490 \\
\hline $9 / 8 / 2006$ & 183 & 324 & 543 & 109 & 221 & 215 & 322 \\
\hline $15 e 16 / 08 / 2006$ & 190 & 503 & 793 & 133 & 305 & 370 & 488 \\
\hline $22 / 8 / 2006$ & 197 & 564 & 410 & 274 & 96 & 290 & 314 \\
\hline $4 / 9 / 2006$ & 204 & 708 & 465 & 248 & 153 & 460 & 313 \\
\hline $12 / 9 / 2006$ & 211 & 3.274 & 2.933 & 2.573 & 2.411 & 701 & 522 \\
\hline $26 / 9 / 2006$ & 218 & 2.461 & 2.013 & 1.815 & 1.313 & 646 & 700 \\
\hline $2 / 10 / 2006$ & 225 & 916 & 1.260 & 204 & 375 & 713 & 885 \\
\hline $17 / 10 / 2006$ & 240 & 690 & 801 & 126 & 309 & 564 & 493 \\
\hline $30 / 10 / 2006$ & 253 & 869 & 555 & 186 & 398 & 682 & 157 \\
\hline $6 / 11 / 2006$ & 259 & 673 & 878 & 146 & 409 & 527 & 470 \\
\hline $13 / 11 / 2006$ & 266 & 3.645 & 687 & 3.081 & 211 & 564 & 470 \\
\hline
\end{tabular}

Tabela A2 - Valores das concentrações de sólidos suspensos totais, sólidos suspensos fixos e sólidos suspensos voláteis afluentes e efluentes $(\mathrm{mg} / \mathrm{L})$.

\begin{tabular}{|r|r|r|r|r|r|r|r|}
\hline \multicolumn{1}{|c|}{ Data } & \multicolumn{1}{c|}{ Dia } & \multicolumn{1}{c|}{ SSTa } & \multicolumn{1}{c|}{ SSTe } & \multicolumn{1}{c|}{ SSFa } & \multicolumn{1}{c|}{ SSFe } & \multicolumn{1}{c|}{ SSVa } & \multicolumn{1}{c|}{ SSVe } \\
\hline $15 / 2 / 2006$ & 6 & 174 & 82 & 48 & 12 & 126 & 70 \\
\hline $21 / 2 / 2003$ & 12 & 86 & 135 & 12 & 26 & 74 & 109 \\
\hline $6 / 3 / 2006$ & 33 & 89 & 106 & & 11 & & \\
\hline $29 / 3 / 2006$ & 54 & 114 & 78 & 16 & 21 & 98 & 56 \\
\hline $10 / 4 / 2006$ & 68 & 297 & 144 & 68 & 47 & 229 & 98 \\
\hline $26 / 4 / 2004$ & 82 & 191 & 102 & 11 & 28 & 180 & 74 \\
\hline $18 / 7 / 2006$ & 162 & 112 & 76 & 6 & 13 & 106 & 63 \\
\hline $2 / 8 / 2006$ & 176 & 139 & 75 & 4 & 0 & 135 & 75 \\
\hline $9 / 8 / 2006$ & 183 & 103 & 61 & 13 & 3 & 90 & 59 \\
\hline $15 e 16 / 08 / 2006$ & 190 & 154 & 63 & 14 & 3 & 140 & 60 \\
\hline $22 / 8 / 2006$ & 197 & 211 & 57 & 26 & 0 & 185 & 57 \\
\hline $4 / 9 / 2006$ & 204 & 177 & 74 & 32 & 2 & 145 & 72 \\
\hline $12 / 9 / 2006$ & 211 & 252 & 72 & 151 & 54 & 101 & 72 \\
\hline $26 / 9 / 2006$ & 218 & 351 & 60 & 84 & 12 & 267 & 48 \\
\hline $2 / 10 / 2006$ & 225 & 287 & 68 & 47 & 4 & 240 & 64 \\
\hline $17 / 10 / 2006$ & 240 & 213 & 86 & 0 & 0 & 213 & 86 \\
\hline $30 / 10 / 2006$ & 253 & 372 & 90 & 57 & 7 & 314 & 83 \\
\hline $6 / 11 / 2006$ & 259 & 328 & 139 & 36 & 25 & 292 & 114 \\
\hline $13 / 11 / 2006$ & 266 & 255 & 92 & 73 & 16 & 183 & 76 \\
\hline
\end{tabular}


Tabela A3 - Valores das concentrações de sólidos dissolvidos totais, sólidos dissolvidos fixos e sólidos dissolvidos voláteis afluentes e efluentes $(\mathrm{mg} / \mathrm{L})$.

\begin{tabular}{|r|r|r|r|r|r|r|r|}
\hline \multicolumn{1}{|c|}{ Data } & \multicolumn{1}{c|}{ Dia } & \multicolumn{1}{c|}{ SDTa } & \multicolumn{1}{c|}{ SDTe } & \multicolumn{1}{c|}{ SDFa } & \multicolumn{1}{c|}{ SDFe } & \multicolumn{1}{c|}{ SDVa } & \multicolumn{1}{c|}{ SDVe } \\
\hline $15 / 2 / 2006$ & 6 & 1323 & 591 & & & & \\
\hline $21 / 2 / 2003$ & 12 & 199 & 855 & 17 & 154 & 1371 & 603 \\
\hline $6 / 3 / 2006$ & 33 & 458 & 626 & & & 211 & 881 \\
\hline $29 / 3 / 2006$ & 54 & 356 & 406 & 166 & 146 & 372 & 428 \\
\hline $10 / 4 / 2006$ & 68 & 568 & 753 & 95 & 255 & 636 & 800 \\
\hline $26 / 4 / 2004$ & 82 & 392 & 904 & 219 & 62 & 403 & 932 \\
\hline $18 / 7 / 2006$ & 162 & 305 & 367 & & & 311 & 380 \\
\hline $2 / 8 / 2006$ & 176 & 368 & 570 & 89 & 155 & 371 & 570 \\
\hline $9 / 8 / 2006$ & 183 & 221 & 482 & 96 & 219 & 234 & 484 \\
\hline $15 \mathrm{e} 16 / 08 / 2006$ & 190 & 349 & 730 & 119 & 302 & 363 & 733 \\
\hline $22 / 8 / 2006$ & 197 & 353 & 353 & 248 & 96 & 378 & 353 \\
\hline $4 / 9 / 2006$ & 204 & 531 & 391 & 216 & 151 & 563 & 393 \\
\hline $12 / 9 / 2006$ & 211 & 3022 & 2861 & 2422 & 2357 & 3173 & 2861 \\
\hline $26 / 9 / 2006$ & 218 & 2111 & 1953 & 1731 & 1301 & 2194 & 1965 \\
\hline $2 / 10 / 2006$ & 225 & 629 & 1192 & 157 & 371 & 676 & 1196 \\
\hline $17 / 10 / 2006$ & 240 & 477 & 715 & 126 & 309 & 477 & 715 \\
\hline $30 / 10 / 2006$ & 253 & 497 & 465 & 129 & 391 & 555 & 472 \\
\hline $6 / 11 / 2006$ & 259 & 346 & 739 & 110 & 384 & 381 & 764 \\
\hline $13 / 11 / 2006$ & 266 & 3390 & 595 & 3008 & 195 & 3463 & 611 \\
\hline
\end{tabular}

Tabela A4 - Valores das concentrações de sólidos totais no perfil do reator (mg/L).

\begin{tabular}{|r|r|r|r|r|r|r|r|r|}
\hline \multicolumn{1}{|c|}{ Data } & Dia & $\mathbf{0 , 2 5} \mathbf{~ m}$ & $\mathbf{0 , 8 5} \mathbf{~ m}$ & $\mathbf{1 , 4 5} \mathbf{~}$ & $\mathbf{2 , 0 5} \mathbf{~}$ & $\mathbf{2 , 6 5} \mathbf{~ m}$ & $\mathbf{3 , 2 5} \mathbf{~}$ & $\mathbf{3 , 8 5} \mathbf{~ m}$ \\
\hline $21 / 2 / 2006$ & 12 & & 2.007 & 2.366 & 1.332 & 1.033 & 540 & 793 \\
\hline $6 / 3 / 2006$ & 33 & 1.500 & 1.697 & 5.642 & 1.324 & 2.852 & 990 & 2.437 \\
\hline $22 / 3 / 2006$ & 47 & 448 & 207 & 445 & 417 & 422 & 332 & \\
\hline $29 / 3 / 2006$ & 54 & 563 & 473 & 436 & 433 & 484 & 468 & 499 \\
\hline $10 / 4 / 2006$ & 68 & 27.640 & 663 & 689 & 738 & 798 & 813 & 898 \\
\hline $26 / 4 / 2004$ & 82 & 30.445 & 1.112 & 988 & 1.070 & 1.046 & 1.002 & 1.023 \\
\hline $18 / 7 / 2006$ & 162 & 33.708 & 491 & 465 & 471 & 489 & 515 & 460 \\
\hline $2 / 8 / 2006$ & 176 & 26.926 & 628 & 589 & 610 & 652 & 691 & 697 \\
\hline $22 / 8 / 2006$ & 197 & 18.849 & 501 & 439 & 432 & 440 & 500 & 424 \\
\hline $4 / 9 / 2006$ & 204 & 20.200 & 19.260 & 740 & 475 & 478 & 490 & 480 \\
\hline $26 / 9 / 2006$ & 218 & 41.823 & 19.221 & 18.284 & 11.226 .25 & 4.758 & 4.209 & 3.628 \\
\hline $2 / 10 / 2006$ & 225 & 33.578 & 15.054 & 14.825 & 14.363 & 13.420 & 11.698 & 856 \\
\hline $17 / 10 / 2006$ & 240 & 36.696 & 19.665 & 14.764 & 18.436 & 16.934 & 1.261 & 1.047 \\
\hline $30 / 10 / 2006$ & 253 & 36.328 & 19.485 & 19.011 & 18.388 & 17.619 & 16.688 & 685 \\
\hline $6 / 11 / 2006$ & 259 & 38.558 & 19.070 & 18.551 & 19.213 & 17.720 & 16.581 & 8.281 \\
\hline $13 / 11 / 2006$ & 266 & 36.559 & 19.785 & 18.764 & 18.000 & 17.129 & 15.838 & 795 \\
\hline
\end{tabular}


Tabela A5 - Valores das concentrações de sólidos totais fixos no perfil do reator $(\mathrm{mg} / \mathrm{L})$.

\begin{tabular}{|c|r|r|r|r|r|r|r|r|}
\hline Data & Dia & $\mathbf{0 , 2 5} \mathbf{~}$ & $\mathbf{0 , 8 5} \mathbf{~}$ & $\mathbf{1 , 4 5} \mathbf{~}$ & $\mathbf{2 , 0 5} \mathbf{~}$ & $\mathbf{2 , 6 5} \mathbf{~}$ & $\mathbf{3 , 2 5} \mathbf{~}$ & $\mathbf{3 , 8 5} \mathbf{~}$ \\
\hline $21 / 2 / 2006$ & 12 & & 1250 & 1502 & 412 & 280 & & 73 \\
\hline $6 / 3 / 2006$ & 33 & 1410 & 643 & 2654 & 422 & 1558 & & 620 \\
\hline $22 / 3 / 2006$ & 47 & & & 142 & 180 & 163 & 197 & \\
\hline $29 / 3 / 2006$ & 54 & 191 & 197 & 143 & 156 & 145 & 139 & 156 \\
\hline $10 / 4 / 2006$ & 68 & 10537 & 210 & 213 & 163 & 225 & 223 & 243 \\
\hline $26 / 4 / 2004$ & 82 & 10858 & 542 & 475 & 696 & 527 & 488 & 445 \\
\hline $18 / 7 / 2006$ & 162 & 10523 & 106 & 151 & 155 & 101 & 140 & 8 \\
\hline $2 / 8 / 2006$ & 176 & 8293 & 340 & 180 & 160 & 173 & 366 & 263 \\
\hline $22 / 8 / 2006$ & 197 & 4942 & 173 & 159 & 160 & 176 & 224 & 184 \\
\hline $4 / 9 / 2006$ & 204 & 5227 & 5272 & 320 & 47 & 145 & 122 & 86 \\
\hline $26 / 9 / 2006$ & 218 & 14140 & 7276 & 7178 & 4375 & 3595 & 3151 & 2753 \\
\hline $2 / 10 / 2006$ & 225 & 10019 & 4338 & 4423 & 4303 & 3918 & 3456 & 162 \\
\hline $17 / 10 / 2006$ & 240 & 12182 & 6220 & 4819 & 6034 & 5536 & 99 & 582 \\
\hline $30 / 10 / 2006$ & 253 & 12123 & 6471 & 6250 & 5944 & 5920 & 5610 & 395 \\
\hline $6 / 11 / 2006$ & 259 & 13335 & 6449 & 6213 & 6415 & 6049 & 5683 & 2801 \\
\hline $13 / 11 / 2006$ & 266 & 12633 & 7026 & 6573 & 6484 & 5941 & 5380 & 363 \\
\hline
\end{tabular}

Tabela A6 - Valores das concentrações de sólidos totais voláteis no perfil do reator(mg/L).

\begin{tabular}{|r|r|r|r|r|r|r|r|r|}
\hline \multicolumn{1}{|l}{ Data } & Dia & $\mathbf{0 , 2 5} \mathbf{~ m}$ & $\mathbf{0 , 8 5} \mathbf{~}$ & $\mathbf{1 , 4 5} \mathbf{~}$ & $\mathbf{2 , 0 5} \mathbf{~ m}$ & $\mathbf{2 , 6 5} \mathbf{~}$ & $\mathbf{3 , 2 5} \mathbf{~ m}$ & $\mathbf{3 , 8 5} \mathbf{~ m}$ \\
\hline $21 / 2 / 2006$ & 12 & & 757 & 864 & 920 & $\mathbf{7 5 3}$ & & $\mathbf{7 2 0}$ \\
\hline $6 / 3 / 2006$ & 33 & 90 & 1.053 & 2.988 & 902 & 1.295 & & 1.816 \\
\hline $22 / 3 / 2006$ & 47 & & & 303 & 237 & 258 & 135 & \\
\hline $29 / 3 / 2006$ & 54 & 371 & 276 & 294 & 276 & 339 & 329 & 343 \\
\hline $10 / 4 / 2006$ & 68 & 17.103 & 453 & 476 & 575 & 573 & 590 & 655 \\
\hline $26 / 4 / 2004$ & 82 & 19.587 & 570 & 513 & 374 & 520 & 513 & 578 \\
\hline $18 / 7 / 2006$ & 162 & 23.185 & 386 & 314 & 316 & 388 & 375 & 452 \\
\hline $2 / 8 / 2006$ & 176 & 18.633 & 287 & 409 & 450 & 480 & 326 & 435 \\
\hline $22 / 8 / 2006$ & 197 & 13.907 & 329 & 280 & 272 & 264 & 276 & 240 \\
\hline $4 / 9 / 2006$ & 204 & 14.973 & 13.988 & 420 & 428 & 333 & 367 & 394 \\
\hline $26 / 9 / 2006$ & 218 & 27.683 & 11.945 & 11.106 & 6.851 & 1.163 & 1.058 & 875 \\
\hline $2 / 10 / 2006$ & 225 & 23.559 & 10.716 & 10.403 & 10.060 & 9.503 & 8.241 & 694 \\
\hline $17 / 10 / 2006$ & 240 & 24.514 & 13.445 & 9.945 & 12.403 & 11.398 & 1.163 & 465 \\
\hline $30 / 10 / 2006$ & 253 & 24.205 & 13.014 & 12.761 & 12.445 & 11.699 & 11.078 & 290 \\
\hline $6 / 11 / 2006$ & 259 & 25.223 & 12.621 & 12.339 & 12.798 & 11.671 & 10.899 & 5.480 \\
\hline $13 / 11 / 2006$ & 266 & 23.926 & 12.759 & 12.191 & 11.516 & 11.188 & 10.458 & 431 \\
\hline
\end{tabular}


Tabela A7 - Valores das concentrações de sólidos suspensos totais no perfil do reator $(\mathrm{mg} / \mathrm{L})$.

\begin{tabular}{|r|r|r|r|r|r|r|r|r|}
\hline \multicolumn{1}{l|}{ Data } & Dia & $\mathbf{0 , 2 5} \mathbf{~ m}$ & $\mathbf{0 , 8 5} \mathbf{~}$ & $\mathbf{1 , 4 5} \mathbf{~}$ & $\mathbf{2 , 0 5} \mathbf{~}$ & $\mathbf{2 , 6 5} \mathbf{~}$ & $\mathbf{3 , 2 5} \mathbf{~ m}$ & $\mathbf{3 , 8 5} \mathbf{~}$ \\
\hline $21 / 2 / 2006$ & 12 & 202 & 752 & 1.520 & 76 & 308 & 86 & 140 \\
\hline $6 / 3 / 2006$ & 33 & 116 & 628 & 2.372 & 336 & 1.660 & 792 & 1.364 \\
\hline $22 / 3 / 2006$ & 47 & 180 & 164 & 124 & 112 & 128 & 84 & 44 \\
\hline $29 / 3 / 2006$ & 54 & 207 & 103 & 88 & 70 & 70 & 84 & 38 \\
\hline $10 / 4 / 2006$ & 68 & 27.482 & 104 & 52 & 104 & 76 & 44 & 72 \\
\hline $26 / 4 / 2004$ & 82 & 28.881 & 194 & 140 & 178 & 180 & 120 & 116 \\
\hline $18 / 7 / 2006$ & 162 & 29.003 & 144 & 136 & 138 & 148 & 152 & 108 \\
\hline $2 / 8 / 2006$ & 176 & 30.654 & 100 & 97 & 60 & 77 & 90 & 93 \\
\hline $22 / 8 / 2006$ & 197 & 17.468 & 140 & 80 & 76 & 64 & 104 & 84 \\
\hline $4 / 9 / 2006$ & 204 & 16.495 & 20.401 & 514 & 76 & 70 & 86 & 78 \\
\hline $26 / 9 / 2006$ & 218 & 38.310 & 15.873 & 13.448 & 14.855 & 565 & 102 & 86 \\
\hline $2 / 10 / 2006$ & 225 & 31.855 & 14.402 & 13.935 & 13.480 & 12.375 & 4.210 & 235 \\
\hline $17 / 10 / 2006$ & 240 & 35.795 & 20.610 & 19.018 & 17.748 & 14.890 & 483 & 213 \\
\hline $30 / 10 / 2006$ & 253 & 35.733 & 17.788 & 16.960 & 17.715 & 17.322 & 6.942 & 180 \\
\hline $6 / 11 / 2006$ & 259 & 38.283 & 18.008 & 18.038 & 17.595 & 16.390 & 14.620 & 7.680 \\
\hline $13 / 11 / 2006$ & 266 & 31.749 & 18.935 & 17.585 & 16.778 & 17.393 & 15.563 & 490 \\
\hline
\end{tabular}

Tabela A8 - Valores das concentrações de sólidos suspensos fixos no perfil do reator(mg/L).

\begin{tabular}{|r|r|r|r|r|r|r|r|r|}
\hline \multicolumn{1}{|l}{ Data } & \multicolumn{1}{|l}{ Dia } & $\mathbf{0 , 2 5} \mathbf{~}$ & $\mathbf{0 , 8 5} \mathbf{~ m}$ & $\mathbf{1 , 4 5} \mathbf{~}$ & $\mathbf{2 , 0 5} \mathbf{~}$ & $\mathbf{2 , 6 5} \mathbf{~}$ & $\mathbf{3 , 2 5} \mathbf{~}$ & $\mathbf{3 , 8 5} \mathbf{~ m}$ \\
\hline $21 / 2 / 2003$ & 12 & 130 & 588 & 1.312 & 14 & 260 & 40 & 64 \\
\hline $6 / 3 / 2006$ & 33 & 104 & 368 & 1.340 & 140 & 936 & 424 & 784 \\
\hline $22 / 3 / 2006$ & 47 & 63 & 32 & 16 & 12 & 48 & 16 & 4 \\
\hline $29 / 3 / 2006$ & 54 & 53 & 10 & 18 & & & & \\
\hline $10 / 4 / 2006$ & 68 & 10.687 & 16 & & 28 & 8 & 12 & 4 \\
\hline $26 / 4 / 2004$ & 82 & 10.858 & 56 & 38 & 46 & 52 & 32 & 40 \\
\hline $18 / 7 / 2006$ & 162 & 9.010 & 32 & 30 & 22 & 36 & 40 & 20 \\
\hline $2 / 8 / 2006$ & 176 & 7.844 & 10 & 7 & 3 & 0 & & \\
\hline $22 / 8 / 2006$ & 197 & 4.397 & 16 & 12 & 4 & 16 & 8 & 12 \\
\hline $4 / 9 / 2006$ & 204 & 3.247 & 5.355 & 105 & 6 & 4 & 16 & 14 \\
\hline $26 / 9 / 2006$ & 218 & 11.703 & 4.560 & 3.375 & 4.548 & 187 & 28 & 8 \\
\hline $2 / 10 / 2006$ & 225 & 9.315 & 4.350 & 4.105 & 4.012 & 3.375 & 1.170 & 40 \\
\hline $17 / 10 / 2006$ & 240 & 12.067 & 7.050 & 6.348 & 5.510 & 4.172 & 156 & 50 \\
\hline $30 / 10 / 2006$ & 253 & 12.153 & 5.698 & 5.725 & 5.878 & 5.718 & 2.114 & 70 \\
\hline $6 / 11 / 2006$ & 259 & 13.330 & 6.043 & 6.123 & 5.720 & 5.380 & 4.780 & 2.500 \\
\hline $13 / 11 / 2006$ & 266 & 12.653 & 6.825 & 6.548 & 6.235 & 6.493 & 5.525 & 390 \\
\hline
\end{tabular}


Tabela A9 - Valores das concentrações de sólidos suspensos voláteis no perfil do reator $(\mathrm{mg} / \mathrm{L})$.

\begin{tabular}{|r|r|r|r|r|r|r|r|r|}
\hline \multicolumn{1}{|l|}{ Data } & Dia & $\mathbf{0 , 2 5} \mathbf{~}$ & $\mathbf{0 , 8 5} \mathbf{~}$ & $\mathbf{1 , 4 5} \mathbf{~}$ & $\mathbf{2 , 0 5} \mathbf{~}$ & $\mathbf{2 , 6 5} \mathbf{~}$ & $\mathbf{3 , 2 5} \mathbf{~}$ & $\mathbf{3 , 8 5} \mathbf{~}$ \\
\hline $21 / 2 / 2003$ & 12 & 72 & 164 & 208 & 62 & 48 & 46 & 76 \\
\hline $6 / 3 / 2006$ & 33 & 12 & 260 & 1.032 & 196 & 724 & 368 & 580 \\
\hline $22 / 3 / 2006$ & 47 & 118 & 132 & 108 & 100 & 80 & 68 & 40 \\
\hline $29 / 3 / 2006$ & 54 & 153 & 93 & 70 & & & & \\
\hline $10 / 4 / 2006$ & 68 & 16.795 & 88 & & 76 & 68 & 32 & 68 \\
\hline $26 / 4 / 2004$ & 82 & 18.024 & 138 & 102 & 132 & 128 & 88 & 76 \\
\hline $18 / 7 / 2006$ & 162 & 19.992 & 112 & 106 & 116 & 112 & 112 & 88 \\
\hline $2 / 8 / 2006$ & 176 & 22.810 & 90 & 90 & 57 & 77 & & \\
\hline $22 / 8 / 2006$ & 197 & 13.070 & 124 & 68 & 72 & 48 & 96 & 72 \\
\hline $4 / 9 / 2006$ & 204 & 13.248 & 15.046 & 409 & 70 & 66 & 70 & 64 \\
\hline $26 / 9 / 2006$ & 218 & 26.608 & 11.313 & 10.103 & 10.308 & 378 & 74 & 78 \\
\hline $2 / 10 / 2006$ & 225 & 22.570 & 10.052 & 9.830 & 9.468 & 9.000 & 3.040 & 195 \\
\hline $17 / 10 / 206$ & 240 & 23.728 & 13.560 & 12.670 & 12.237 & 10.717 & 328 & 163 \\
\hline $30 / 10 / 2006$ & 253 & 23.580 & 12.090 & 11.235 & 11.297 & 11.605 & 4.829 & 110 \\
\hline $6 / 11 / 2006$ & 259 & 24.953 & 11.965 & 11.915 & 11.875 & 11.010 & 9.840 & 5.180 \\
\hline $13 / 11 / 2006$ & 266 & 19.096 & 12.110 & 11.038 & 10.543 & 10.900 & 10.038 & 100 \\
\hline
\end{tabular}

Tabela A10 - Valores das concentrações de sólidos sedimentáveis no perfil do reator $(\mathrm{mg} / \mathrm{L})$.

\begin{tabular}{|r|r|r|r|r|r|r|r|r|}
\hline \multicolumn{1}{c|}{ Data } & Dia & $\mathbf{0 , 2 5} \mathbf{~ m}$ & $\mathbf{0 , 8 5} \mathbf{~ m}$ & $\mathbf{1 , 4 5} \mathbf{~}$ & $\mathbf{2 , 0 5} \mathbf{~}$ & $\mathbf{2 , 6 5} \mathbf{~}$ & $\mathbf{3 , 2 5} \mathbf{~ m}$ & $\mathbf{3 , 8 5} \mathbf{~ m}$ \\
\hline $22 / 3 / 2006$ & 47 & 0,8 & 1 & 0,8 & 1 & 0,2 & 0,2 & 0 \\
\hline $10 / 4 / 2006$ & 68 & 0,2 & 0,2 & 0,2 & 0,2 & 0,2 & 0,2 & 0,2 \\
\hline $2 / 8 / 2006$ & 176 & 850 & 0 & 0 & 0 & 0,2 & 0 & 0,2 \\
\hline $22 / 8 / 2006$ & 197 & 830 & 0,06 & 0,02 & 0,01 & 0 & 0,01 & 0,05 \\
\hline $4 / 9 / 2006$ & 204 & 920 & 960 & 10 & 0,2 & 0 & 0 & 0 \\
\hline $26 / 9 / 2006$ & 218 & 998 & 800 & 640 & 715 & 13 & 0,1 & 0,9 \\
\hline $2 / 10 / 2006$ & 225 & 1000 & 900 & 650 & 650 & 650 & 800 & 2 \\
\hline $17 / 10 / 206$ & 240 & 950 & 850 & 780 & 790 & 720 & 10 & 2 \\
\hline $30 / 10 / 2006$ & 253 & 950 & 850 & 800 & 800 & 760 & 340 & 2,4 \\
\hline $6 / 11 / 2006$ & 259 & 1000 & 800 & 800 & 780 & 720 & 330 & 150 \\
\hline $13 / 11 / 2006$ & 266 & 1000 & 840 & 800 & 710 & 650 & 600 & 2 \\
\hline
\end{tabular}


Tabela A11 - Valores das concentrações de $\mathrm{pH}$ e alcalinidades parciais e totais afluentes e efluentes $\left(\mathrm{mgCaCO}_{3} / \mathrm{L}\right)$.

\begin{tabular}{|r|r|r|r|r|r|r|r|}
\hline \multicolumn{1}{|c|}{ Data } & Dia & \multicolumn{1}{|c|}{ pHa } & \multicolumn{1}{c|}{ pHe } & Alc.Parc.a & Alc. Tot.a & Alc.Parc.e & Alc. Tot.e \\
\hline $15 / 2 / 2006$ & 6 & 7,8 & 7,8 & & 298 & & 250 \\
\hline $21 / 2 / 2003$ & 12 & 8,1 & 8,7 & & 138 & & 388 \\
\hline $27 / 2 / 2006$ & 19 & 7,3 & 7,3 & 180 & 243 & 180 & 250 \\
\hline $6 / 3 / 2006$ & 33 & 7,3 & 7,0 & 190 & 230 & 168 & 242 \\
\hline $14 / 3 / 2006$ & 40 & 7,0 & 7,1 & 140 & 212 & 142 & 286 \\
\hline $22 / 3 / 2006$ & 47 & 7,0 & 6,7 & 34 & 95 & 55 & 123 \\
\hline $29 / 3 / 2006$ & 54 & 7,4 & 6,3 & 185 & 237 & & 221 \\
\hline $5 / 4 / 2006$ & 61 & 7,3 & 7,3 & 196 & 245 & 203 & 282 \\
\hline $10 / 4 / 2006$ & 68 & 7,1 & 7,2 & 235 & 343 & 228 & 324 \\
\hline $19 / 4 / 2006$ & 75 & 7,3 & 7,1 & 165 & 243 & 194 & 277 \\
\hline $26 / 4 / 2004$ & 82 & 7,3 & 7,3 & 177 & 273 & 252 & 364 \\
\hline $18 / 7 / 2006$ & 162 & 7,2 & 6,9 & 155 & 240 & 195 & 282 \\
\hline $26 / 7 / 2006$ & 169 & 7,0 & 7,0 & 158 & 252 & 160 & 279 \\
\hline $2 / 8 / 2006$ & 176 & 6,8 & 7,1 & 123 & 175 & 192 & 283 \\
\hline $9 / 8 / 2006$ & 183 & 7,2 & 7,1 & 155 & 198 & 169 & 283 \\
\hline $15 e 16 / 08 / 2006$ & 190 & 7,0 & 7,9 & 170 & 210 & 189 & 298 \\
\hline $22 / 8 / 2006$ & 197 & 7,2 & 7,1 & 204 & 313 & 179 & 272 \\
\hline $4 / 9 / 2006$ & 204 & 6,7 & 6,4 & 141 & 250 & 105 & 242 \\
\hline $12 / 9 / 2006$ & 211 & 7,4 & 7,4 & 309 & 471 & 287 & 476 \\
\hline $26 / 9 / 2006$ & 218 & 7,5 & 7,1 & 309 & 415 & 307 & 448 \\
\hline $2 / 10 / 2006$ & 225 & 6,9 & 6,8 & 141 & 210 & 192 & 309 \\
\hline $17 / 10 / 2006$ & 240 & 7,1 & 7,1 & 155 & 249 & 149 & 391 \\
\hline $30 / 10 / 2006$ & 253 & 7,1 & 6,8 & 154 & 261 & 206 & 340 \\
\hline $6 / 11 / 2006$ & 259 & 7,1 & 7,2 & 155 & 274 & 295 & 447 \\
\hline $13 / 11 / 2006$ & 266 & 7,6 & 7,1 & 363 & 520 & 290 & 449 \\
\hline
\end{tabular}


Tabela A12 - Valores das concentrações de DQO e DBO brutas e filtradas afluentes e efluentes $(\mathrm{mg} / \mathrm{L})$.

\begin{tabular}{|r|r|r|r|r|r|r|r|r|c|}
\hline \multicolumn{1}{|c|}{ Data } & Dia & DQOba & DQObe & DQOfa & DQOfe & DBOba & DBObe & DBOfa & DBOfe \\
\hline $15 / 2 / 2006$ & 6 & 429 & 314 & & & 155 & 64 & & \\
\hline $21 / 2 / 2003$ & 12 & 206 & 376 & & & 75 & 91 & & \\
\hline $27 / 2 / 2006$ & 19 & 591 & 562 & & & & & & \\
\hline $6 / 3 / 2006$ & 33 & 348 & 502 & & & 115 & 83 & & \\
\hline $14 / 3 / 2006$ & 40 & 403 & 355 & & & 402 & 299 & & \\
\hline $22 / 3 / 2006$ & 47 & 204 & 257 & & & & & & \\
\hline $29 / 3 / 2006$ & 54 & 289 & 209 & & & 262 & 304 & & \\
\hline $10 / 4 / 2006$ & 68 & 657 & 501 & 237 & 255 & & & & \\
\hline $19 / 4 / 2006$ & 75 & 448 & 512 & 222 & 214 & 489 & 461 & & \\
\hline $26 / 4 / 2004$ & 82 & 543 & 415 & 229 & 287 & 499 & 232 & & \\
\hline $18 / 7 / 2006$ & 162 & 412 & 327 & 254 & 200 & & & & \\
\hline $26 / 7 / 2006$ & 169 & 437 & 549 & 281 & 351 & 344 & 388 & 260 & 331 \\
\hline $2 / 8 / 2006$ & 176 & 350 & 359 & 130 & 227 & 141 & 293 & 162 & 209 \\
\hline $9 / 8 / 2006$ & 183 & 315 & 444 & 133 & 311 & & & & \\
\hline $15 e 16 / 08 / 2006$ & 190 & 436 & 392 & 183 & 298 & 237 & 350 & 237 & 275 \\
\hline $22 / 8 / 2006$ & 197 & 747 & 431 & 397 & 317 & 336 & 271 & 125 & 84 \\
\hline $4 / 9 / 2006$ & 204 & 507 & 433 & 208 & 293 & 380 & 320 & & \\
\hline $12 / 9 / 2006$ & 211 & 818 & 464 & 381 & 406 & 472 & 283 & 237 & 133 \\
\hline $26 / 9 / 2006$ & 218 & 917 & 495 & 357 & 404 & 470 & 423 & & \\
\hline $2 / 10 / 2006$ & 225 & 668 & 385 & 212 & 244 & & & & \\
\hline $17 / 10 / 2006$ & 240 & 585 & 372 & 224 & 222 & & & 277 & 178 \\
\hline $30 / 10 / 2006$ & 253 & 822 & 389 & 260 & 195 & & & & \\
\hline $6 / 11 / 2006$ & 259 & 637 & 438 & 152 & 157 & & & & \\
\hline $13 / 11 / 2006$ & 266 & 745 & 290 & 370 & 181 & 520 & 360 & 248 & 218 \\
\hline
\end{tabular}

Tabela A13 - Valores das concentrações de ácidos voláteis afluentes (mg/L).

\begin{tabular}{|r|r|r|r|r|r|r|r|r|}
\hline \multicolumn{1}{|c|}{ Data } & Dia & Acético & Propiônico & Isobutírico & Butírico & Isovalérico & Valérico & Capróico \\
\hline $14 / 3 / 2006$ & 40 & 26 & 2 & 0 & 0 & 0 & 0 & 0 \\
\hline $29 / 3 / 2006$ & 54 & 14 & 1 & 0 & 0 & 0 & 0 & 0 \\
\hline $18 / 7 / 2006$ & 162 & 64 & 14 & 1 & 0 & 2 & 1 & 8 \\
\hline $26 / 7 / 2006$ & 169 & 37 & 17 & 1 & 3 & 2 & 1 & 0 \\
\hline $2 / 8 / 2006$ & 176 & 13 & 3 & 1 & 1 & 2 & 0 & 0 \\
\hline $9 / 8 / 2006$ & 183 & 4 & 0 & 0 & 0 & 1 & 0 & 0 \\
\hline $15 e 16 / 08 / 2006$ & 190 & 12 & 2 & 1 & 0 & 2 & 0 & 0 \\
\hline $22 / 8 / 2006$ & 197 & 37 & 10 & 2 & 2 & 3 & 1 & 0 \\
\hline $4 / 9 / 2006$ & 204 & 10 & 0 & 0 & 0 & 2 & 0 & 0 \\
\hline $12 / 9 / 2006$ & 211 & 45 & 11 & 1 & 3 & 3 & 1 & 0 \\
\hline $26 / 9 / 2006$ & 218 & 26 & 4 & 1 & 1 & 2 & 3 & 0 \\
\hline $2 / 10 / 2006$ & 225 & 19 & 10 & 2 & 1 & 3 & 0 & 0 \\
\hline $17 / 10 / 2006$ & 240 & 7 & 1 & 1 & & 1 & 0 & 0 \\
\hline $30 / 10 / 2006$ & 253 & 13 & 0 & 0 & 0 & 0 & 2 & 0 \\
\hline $6 / 11 / 2006$ & 259 & 24 & 2 & 1 & 0 & 2 & 0 & 0 \\
\hline
\end{tabular}


Tabela A14 - Valores das concentrações de ácidos voláteis efluentes (mg/L).

\begin{tabular}{|r|r|r|r|r|r|r|r|r|}
\hline \multicolumn{1}{|c|}{ Data } & Dia & Acético & Propiônico & Isobutírico & Butírico & Isovalérico & Valérico & Capróico \\
\hline $15 / 2 / 2006$ & 6 & 0 & 0 & 0 & 0 & 0 & 0 & 0 \\
\hline $21 / 2 / 2006$ & 12 & 0 & 0 & 0 & 0 & 2 & 0 & 0 \\
\hline $6 / 3 / 2006$ & 26 & 35 & 0 & 0 & 0 & 0 & 0 & 0 \\
\hline $14 / 3 / 2006$ & 33 & 32 & 0 & 0 & 0 & 2 & 0 & 0 \\
\hline $29 / 3 / 2006$ & 47 & 37 & 8 & 2 & 2 & 4 & 0 & 0 \\
\hline $13 / 7 / 2006$ & 82 & 39 & 5 & 2 & 1 & 3 & 0 & 0 \\
\hline $18 / 7 / 2006$ & 162 & 62 & 4 & 2 & 0 & 2 & 0 & 0 \\
\hline $26 / 7 / 2006$ & 169 & 61 & 18 & 2 & 5 & 4 & 2 & 0 \\
\hline $2 / 8 / 2006$ & 176 & 34 & 1 & 2 & 0 & 4 & 0 & 0 \\
\hline $9 / 8 / 2006$ & 183 & 57 & 9 & 3 & 4 & 5 & 1 & 1 \\
\hline $15 e 16 / 08 / 2006$ & 190 & 105 & 3 & 3 & 2 & 5 & 0 & 0 \\
\hline $22 / 8 / 2006$ & 197 & 77 & 8 & 4 & 2 & 5 & 0 & 0 \\
\hline $4 / 9 / 2006$ & 204 & 57 & 7 & 4 & 4 & 8 & 1 & 2 \\
\hline $12 / 9 / 2006$ & 211 & 44 & 11 & 1 & 3 & 3 & 1 & 0 \\
\hline $26 / 9 / 2006$ & 218 & 26 & 4 & 1 & 1 & 2 & 0 & 0 \\
\hline $2 / 10 / 2006$ & 225 & 19 & 10 & 2 & 1 & 3 & 0 & 0 \\
\hline $17 / 10 / 2006$ & 240 & 8 & 1 & 1 & 0 & 1 & 0 & 0 \\
\hline $30 / 10 / 2006$ & 253 & 7 & 4 & 1 & 0 & 1 & 0 & 0 \\
\hline $6 / 11 / 2006$ & 259 & 13 & 0 & 0 & 0 & 0 & 0 & 0 \\
\hline
\end{tabular}

Tabela A15 - Valores das concentrações da série do nitrogênio afluentes e efluentes $(\mathrm{mg} / \mathrm{L})$.

\begin{tabular}{|c|c|c|c|c|c|c|c|c|c|c|c|}
\hline Data & Dia & NTKa & NTKe & $\mathrm{N}-\mathrm{NH}_{3} \mathrm{a}$ & $\mathrm{N}-\mathrm{NH}_{3} \mathrm{e}$ & Norg a & Norg e & $\mathrm{NO}_{2}{ }^{-a}$ & $\mathrm{NO}_{2}^{-} \mathrm{e}$ & $\begin{array}{c}\mathrm{NO}_{3} \\
{ }_{2}\end{array}$ & $\begin{array}{c}\mathrm{NO}_{3}{ }^{-} \\
\mathrm{e}^{-}\end{array}$ \\
\hline $15 / 2 / 2006$ & 6 & & & 91 & 35 & & & & & & \\
\hline $21 / 2 / 2003$ & 12 & & & 21 & 48 & & & & & & \\
\hline $27 / 2 / 2006$ & 19 & & & 80 & 66 & & & & & & \\
\hline $14 / 3 / 2006$ & 40 & 63 & 65 & 39 & 38 & 23 & 26 & & & & \\
\hline $22 / 3 / 2006$ & 47 & 26 & 31 & 14 & 24 & 12 & 7 & & & & \\
\hline $10 / 4 / 2006$ & 68 & 85 & 55 & 68 & 52 & 18 & 3 & & & & \\
\hline $19 / 4 / 2006$ & 75 & & & 46 & 48 & & & 0,0029 & 0,0061 & 2 & 2 \\
\hline $26 / 4 / 2004$ & 82 & 55 & 58 & 54 & 48 & 1 & 10 & 0,0096 & 0,0101 & 2 & 5 \\
\hline $26 / 7 / 2006$ & 169 & 76 & 76 & 60 & 56 & 17 & 20 & 0,0042 & 0,0057 & 1 & 1 \\
\hline $2 / 8 / 2006$ & 176 & 45 & 53 & 28 & 45 & 17 & 8 & 0,0032 & 0,0114 & 8 & 2 \\
\hline $9 / 8 / 2006$ & 183 & 47 & 60 & 37 & 54 & 10 & 7 & 0,0036 & 0,0051 & 2 & 3 \\
\hline $15 \mathrm{e} 16 / 08 / 2006$ & 190 & 54 & 53 & 44 & 50 & 11 & 2 & 0,0047 & 0,0033 & 2 & 4 \\
\hline $22 / 8 / 2006$ & 197 & 92 & 62 & 72 & 53 & 20 & 9 & 0,0085 & 0,0081 & 3 & 3 \\
\hline $4 / 9 / 2006$ & 204 & 60 & 61 & 44 & 53 & 16 & 8 & 0,0024 & 0,0022 & 1 & 2 \\
\hline $12 / 9 / 2006$ & 211 & 100 & 83 & 73 & 64 & 27 & 19 & 0,0029 & 0,0037 & 5 & 7 \\
\hline $26 / 9 / 2006$ & 218 & 81 & 70 & 55 & 44 & 26 & 27 & 0,0036 & 0,0032 & 8 & 8 \\
\hline $2 / 10 / 2006$ & 225 & 59 & 59 & 45 & 51 & 15 & 8 & 0,0054 & 0,0047 & 2 & 3 \\
\hline $17 / 10 / 2006$ & 240 & 73 & 60 & 45 & 53 & 28 & 7 & 0,0033 & 0,006 & 2 & 5 \\
\hline $30 / 10 / 2006$ & 253 & 78 & 65 & 45 & 53 & 33 & 12 & 0,0076 & 0,0058 & 2 & 3 \\
\hline $6 / 11 / 2006$ & 259 & 73 & 67 & 48 & 49 & 26 & 18 & 0,0079 & 0,0165 & 2 & 5 \\
\hline $13 / 11 / 2006$ & 266 & 119 & 89 & 69 & 68 & 50 & 22 & 0,0047 & 0,0041 & 8 & 4 \\
\hline
\end{tabular}


Tabela A16 - Valores das concentrações fósforo total e carbono orgânico total filtrado afluentes e efluentes (mg/L).

\begin{tabular}{|r|r|r|r|r|r|}
\hline \multicolumn{1}{|l|}{ Data } & Dia & \multicolumn{1}{l|}{ Ptotal a } & Ptotal e & COTf a & COTf e \\
\hline $15 / 2 / 2006$ & 6 & 2 & 2 & & \\
\hline $21 / 2 / 2003$ & 12 & 1 & 2 & & \\
\hline $14 / 3 / 2006$ & 40 & 5 & 6 & & \\
\hline $22 / 3 / 2006$ & 47 & 2 & 2 & & \\
\hline $19 / 4 / 2006$ & 75 & 3 & 3 & & \\
\hline $26 / 4 / 2004$ & 82 & 3 & 3 & & \\
\hline $26 / 7 / 2006$ & 169 & 2 & 2 & 75 & 96 \\
\hline $2 / 8 / 2006$ & 176 & 2 & 2 & 25 & 56 \\
\hline $9 / 8 / 2006$ & 183 & 2 & 2 & 33 & 97 \\
\hline $15 e 16 / 08 / 2006$ & 190 & 2 & 2 & 47 & 85 \\
\hline $22 / 8 / 2006$ & 197 & 2 & 2 & 83 & 77 \\
\hline $4 / 9 / 2006$ & 204 & 3 & 3 & 30 & 73 \\
\hline $12 / 9 / 2006$ & 211 & 2 & 2 & 68 & 130 \\
\hline $26 / 9 / 2006$ & 218 & 2 & 2 & 95 & 115 \\
\hline $2 / 10 / 2006$ & 225 & 2 & 2 & 54 & 58 \\
\hline $17 / 10 / 2006$ & 240 & 2 & 2 & 48 & 43 \\
\hline $30 / 10 / 2006$ & 253 & 2 & 2 & 46 & 24 \\
\hline $6 / 11 / 2006$ & 259 & 2 & 2 & 45 & 38 \\
\hline $13 / 11 / 2006$ & 266 & & & 104 & 22 \\
\hline
\end{tabular}


ANEXO B - Análise estatística da demanda química de oxigênio (DQO) 
Tabela B1 - Comparação entre $2^{\mathrm{a}}$ e $3^{\mathrm{a}}$ feira, usando as coletas do dia todo (Afluente).

\begin{tabular}{|c|c|c|c|c|}
\hline$n^{\circ}$ de amostras & $2^{\mathrm{a}}$ & $3^{a}$ & $\left(2^{\mathrm{a}}\right)^{2}$ & $\left(3^{a}\right)^{2}$ \\
\hline 1 & 367 & 428 & 134.689 & 182.927 \\
\hline 2 & 398 & 489 & 158.404 & 239.121 \\
\hline 3 & 639 & 623 & 408.321 & 388.378 \\
\hline 4 & 408 & 608 & 166.382 & 370.272 \\
\hline 5 & 757 & 830 & 572.443 & 688.900 \\
\hline 6 & 550 & 746 & 302.940 & 556.217 \\
\hline 7 & 747 & 822 & 558.009 & 675.684 \\
\hline 8 & 1025 & 579 & 1.050 .625 & 334.662 \\
\hline 9 & 831 & 706 & 690.561 & 498.436 \\
\hline 10 & 350 & 973 & 122.500 & 946.729 \\
\hline 11 & 667 & 795 & 444.889 & 632.025 \\
\hline 12 & 824 & 694 & 678.976 & 481.913 \\
\hline 13 & 357 & 418 & 127.449 & 174.389 \\
\hline 14 & 989 & 366 & 978.121 & 133.809 \\
\hline 15 & 1079 & & 1.164 .241 & \\
\hline$\Sigma$ & 9987,9 & 9076,3 & 7.558 .551 & $6.303 .465,71$ \\
\hline média & 665,86 & 648,31 & & \\
\hline DP & & 179,58 & DP & 254,67 \\
\hline variância & & $32.248,89$ & variância & $64.857,72$ \\
\hline$\left(\sum_{1} X\right)^{2}$ & & $82.379 .221,69$ & $\left(\sum_{2} X\right)^{2}$ & $99.758 .146,41$ \\
\hline Q1 & & $419.235,59$ & Q2 & $908.008,04$ \\
\hline $\mathrm{F}$ & & 2,01 & & \\
\hline $\mathrm{L}$ & & 14 & $L^{\prime}$ & 13 \\
\hline$s 2>s 1$ & & $\mathrm{~L}=\mathrm{N} 2-1$ & & \\
\hline & & $L^{\prime}=N 1-1$ & & \\
\hline$F^{*} 14,13$ & & 2,554 & & \\
\hline
\end{tabular}

Como $F<F^{*} 14,13$ as variâncias são homogêneas.

$t=0,21$

Valores de $\mathrm{t}$ no intervalo:

$\mathrm{t}^{\prime}=1,703$

$\mathrm{t}^{*}=2,052$

$\mathrm{t}^{\prime *}=2,473$

$\mathrm{t}^{* *}=2,771$

$\mathrm{t}^{* * *}=3,69$

Portanto t' > t e a diferença não é significativa. 
Tabela B2 - Comparação entre $2^{\mathrm{a}}$ e $3^{\mathrm{a}}$ feira, usando as coletas do dia todo (Efluente).

\begin{tabular}{|c|c|c|c|c|}
\hline $\begin{array}{c}n^{\circ} \text { de } \\
\text { amostras }\end{array}$ & $2^{a}$ & $3^{a}$ & $\left(2^{a}\right)^{2}$ & $\left(3^{a}\right)^{2}$ \\
\hline 1 & 320 & 395 & 102.400 & 155.946 \\
\hline 2 & 393 & 408 & 154.449 & 166.790 \\
\hline 3 & 379 & 393 & 143.641 & 154.291 \\
\hline 4 & 373,8 & 492 & 139.726 & 242.162 \\
\hline 5 & 371,9 & 515 & 138.309 & 265.431 \\
\hline 6 & 361,9 & 384 & 130.971 & 147.148 \\
\hline 7 & 325,00 & 394 & 105.625 & 154.999 \\
\hline 8 & 377,00 & 362 & 142.129 & 130.682 \\
\hline 9 & 364,00 & 340 & 132.496 & 115.328 \\
\hline 10 & 332 & 311 & 110.224 & 96.534 \\
\hline 11 & 501 & 51 & 251.001 & 263.476 \\
\hline 12 & 364 & 306 & 132.496 & 93.819 \\
\hline 13 & 320 & & 102.400 & \\
\hline 14 & 310 & & 96.100 & \\
\hline 15 & 289 & & 83.521 & \\
\hline$\sum$ & $5.381,60$ & $4.812,10$ & $1.965 .489,66$ & $1.986 .611,99$ \\
\hline média & 358,77 & 401,01 & & \\
\hline DP & & 71,93 & DP & 49,80 \\
\hline variância & & $5.174,53$ & variância & $2.479,65$ \\
\hline$\left(\sum_{1} X\right)^{2}$ & & $23.156 .306,41$ & $\left(\sum_{2} X\right)^{2}$ & $28.961 .618,56$ \\
\hline Q1 & & $56.919,79$ & Q2 & $34.715,09$ \\
\hline $\mathrm{F}$ & & 2,09 & & \\
\hline $\mathrm{L}$ & & 11 & $L^{\prime}$ & 14 \\
\hline$s 1>s 2$ & & $L=N 1-1$ & & \\
\hline & & $L^{\prime}=N 2-1$ & & \\
\hline$F^{*} 14,11$ & & 2,565 & & \\
\hline
\end{tabular}

Como $F<F^{*} 14,11$ as variâncias são homogêneas.

$t=1,8$

Valores de t no intervalo:

$\mathrm{t}^{\prime}=1,708$

$t^{*}=2,06$

$\mathrm{t}^{\prime *}=2,485$

$\mathrm{t}^{* *}=2,787$

$\mathrm{t}^{\star \star *}=3,726$

Portanto $t^{*}>t>t^{\prime}$ e a diferença é significativa, ao nível de 0,1 . 
Tabela B3 - Comparação das médias de DQO afluente entre o período de 8-10 e 10-12 (dados de $2^{\mathrm{a}}$ feira e $3^{\mathrm{a}}$ feira agrupados).

\begin{tabular}{|c|c|c|c|c|}
\hline$n^{\circ}$ de amostras & 8 às 10 & 10 às 12 & $(8 \text { às } 10)^{2}$ & $(10 \text { às } 12)^{2}$ \\
\hline 1 & 367 & 398 & 134.689 & 158.404 \\
\hline 2 & 408 & 757 & 166.382 & 572.443 \\
\hline 3 & 747 & 1025 & 558.009 & 1.050 .625 \\
\hline 4 & 350 & 667 & 122.500 & 444.889 \\
\hline 5 & 357 & 989 & 127.449 & 978.121 \\
\hline 6 & 428 & 489 & 182.927 & 239.121 \\
\hline 7 & 609 & 830 & 370.272 & 688.900 \\
\hline 8 & 579 & 706 & 334.662 & 498.436 \\
\hline 9 & 694 & 418 & 481.913 & 174.389 \\
\hline$\Sigma$ & 4537,8 & 6278,2 & 2.478 .804 & 4.805 .329 \\
\hline média & 504,20 & 697,58 & & \\
\hline DP & 154,45 & & DP & 230,70 \\
\hline variância & $23.855,76$ & & variância & $53.224,56$ \\
\hline$\left(\sum_{1} X\right)^{2}$ & $20.591 .628,84$ & & $\left(\sum_{2} X\right)^{2}$ & $39.415 .795,24$ \\
\hline Q1 & $190.846,08$ & & Q2 & $425.796,52$ \\
\hline $\mathrm{F}$ & 2,23 & & & \\
\hline $\mathrm{L}$ & 8 & & $L^{\prime}$ & 8 \\
\hline$s 2>s 1$ & $L=N 2-1$ & & & \\
\hline & $L^{\prime}=N 1-1$ & & & \\
\hline$F^{\star} 8,8$ & 3,438 & & & \\
\hline
\end{tabular}

Como $F<F^{\star} 8,8$ as variâncias são homogêneas

$t=2,08$

Valores de t no intervalo:

$\mathrm{t}^{\prime}=1,746$

$t^{*}=2,12$

$\mathrm{t}^{\prime *}=2,583$

$\mathrm{t}^{\star *}=2,921$

$\mathrm{t}^{\star \star \star}=4,015$

Portanto $t^{*}>t>t^{\prime}$ e a diferença é significativa (nível $p=0,1$ ). 
Tabela B4 - Comparação das médias de DQO afluente entre o período de 8-10 e 12-13 (dados de $2^{\text {a }}$ feira e $3^{\text {a }}$ feira agrupados).

\begin{tabular}{|c|c|c|c|c|}
\hline$n^{\circ}$ de amostras & 8 às 10 & 12 às 13 & $(8 \text { às } 10)^{2}$ & $(12 \text { às } 13)^{2}$ \\
\hline 1 & 367 & 639 & 134.689 & 408.321 \\
\hline 2 & 408 & 550 & 166.382 & 302.940 \\
\hline 3 & 747 & 831 & 558.009 & 690.561 \\
\hline 4 & 350 & 824 & 122.500 & 678.976 \\
\hline 5 & 357 & 1079 & 127.449 & 1.164 .241 \\
\hline 6 & 428 & 623 & 182.927 & 388.378 \\
\hline 7 & 609 & 746 & 370.272 & 556.217 \\
\hline 8 & 579 & 973 & 334.662 & 946.729 \\
\hline 9 & 694 & 366 & 481.913 & 133.809 \\
\hline$\Sigma$ & 4537,8 & 6631,2 & 2.478 .804 & 5.270 .174 \\
\hline média & 504,20 & 736,80 & & \\
\hline $\mathrm{DP}$ & 154,45 & & DP & 219,18 \\
\hline variância & $23.855,76$ & & variância & $48.038,19$ \\
\hline$\left(\sum_{1} X\right)^{2}$ & $20.591 .628,84$ & & $\left(\sum_{2} X\right)^{2}$ & $43.972 .813,44$ \\
\hline Q1 & $190.846,08$ & & Q2 & $384.305,52$ \\
\hline$(\mathrm{s} 1)^{2}$ & $23.855,76$ & & $(s 2)^{2}$ & $48.038,19$ \\
\hline s1 & 154,45 & & s2 & 219,18 \\
\hline $\mathrm{F}$ & 2,01 & & & \\
\hline $\mathrm{L}$ & 8 & & $L^{\prime}$ & 8 \\
\hline \multirow{2}{*}{$s 2>s 1$} & $I=N 2-1$ & & & \\
\hline & $L^{\prime}=N 1-1$ & & & \\
\hline $\mathrm{F}^{*} 8,8$ & 3,438 & & & \\
\hline
\end{tabular}

Como $\mathrm{F}<\mathrm{F}^{\star} 8,8$ as variâncias são homogêneas

$t=2,60$

Valores de t no intervalo:

$\mathrm{t}^{\prime}=1,746$

$\mathrm{t}^{*}=2,12$

$\mathrm{t}^{\prime *}=2,583$

$t^{* *}=2,921$

$\mathrm{t}^{\star * *}=4,015$

Portanto $t^{* *}>t>t^{* \prime}$ e a diferença é significativa (nível $p=0,02$ ). 
Tabela B5 - Comparação das médias de DQO afluente entre o período de 10-12 e 12-13 (dados de $2^{\text {a }}$ feira e $3^{\text {a }}$ feira agrupados).

\begin{tabular}{|c|c|c|c|c|}
\hline $\mathrm{n}^{\circ}$ de amostras & 10 às 12 & 12 às 13 & $(10 \text { às } 12)^{2}$ & $(12 \text { às } 13)^{2}$ \\
\hline 1 & 398 & 639 & 158.404 & 408.321 \\
\hline 2 & 757 & 550 & 572.443 & 302.940 \\
\hline 3 & 1025 & 831 & 1.050 .625 & 690.561 \\
\hline 4 & 667 & 824 & 444.889 & 678.976 \\
\hline 5 & 989 & 1079 & 978.121 & 1.164 .241 \\
\hline 6 & 489 & 623 & 239.121 & 388.378 \\
\hline 7 & 830 & 746 & 688.900 & 556.217 \\
\hline 8 & 706 & 973 & 498.436 & 946.729 \\
\hline 9 & 418 & 366 & 174.389 & 133.809 \\
\hline$\sum$ & 6278,2 & 6631,2 & 4.805 .329 & $5.270 .173,68$ \\
\hline média & 697,58 & 736,80 & & \\
\hline DP & 230,70 & & DP & 219,18 \\
\hline variância & $53.224,56$ & & variância & $48.038,19$ \\
\hline$\left(\sum_{1} X\right)^{2}$ & $39.415 .795,24$ & & $\left(\sum_{2} X\right)^{2}$ & $43.972 .813,44$ \\
\hline Q1 & $425.796,52$ & & Q2 & $384.305,52$ \\
\hline $\mathrm{F}$ & 0,90 & & & \\
\hline $\mathrm{L}$ & 8 & & $L^{\prime}$ & 8 \\
\hline$s 1>s 2$ & $L=N 1-1$ & & & \\
\hline & $L^{\prime}=N 2-1$ & & & \\
\hline$F^{*} 8,8$ & 3,438 & & & \\
\hline
\end{tabular}

Como $\mathrm{F}<\mathrm{F}^{*} 8,8$ as variâncias são homogêneas

$t=0,37$

Valores de t no intervalo:

$\mathrm{t}^{\prime}=1,746$

$\mathrm{t}^{*}=2,12$

$\mathrm{t}^{\prime *}=2,583$

$\mathrm{t}^{* *}=2,921$

$t^{\star * *}=4,015$

Portanto t' > t, a diferença não é significativa. 
Tabela B6 - Comparação das médias de DQO efluente entre o período de 8-10 e 10-12 (dados de $2^{\mathrm{a}}$ feira e $3^{\mathrm{a}}$ feira agrupados).

\begin{tabular}{|c|c|c|c|c|}
\hline $\mathrm{n}^{\circ}$ de amostras & 8 às 10 & 10 às 12 & $\left(8\right.$ às 10) ${ }^{2}$ & $(10 \text { às } 12)^{2}$ \\
\hline 1 & 320 & 393 & 102.400 & 154.449 \\
\hline 2 & 374 & 372 & 139.726 & 138.309 \\
\hline 3 & 325 & 377 & 105.625 & 142.129 \\
\hline 4 & 332 & 501 & 110.224 & 251.001 \\
\hline 5 & 320 & 310 & 102.400 & 96.100 \\
\hline 6 & 395 & 408 & 155.946 & 166.790 \\
\hline 7 & 492 & 515 & 242.162 & 265.431 \\
\hline 8 & 311 & 306 & 96.534 & 93.819 \\
\hline 9 & 394 & 362 & 154.999 & 130.682 \\
\hline$\Sigma$ & 3262,2 & 3544,3 & $1.210 .018,04$ & $1.438 .712,15$ \\
\hline média & 362,47 & 393,81 & & \\
\hline $\mathrm{DP}$ & 58,71 & & DP & 73,25 \\
\hline variância & $3.447,41$ & & variância & $5.365,93$ \\
\hline$\left(\sum_{1} X\right)^{2}$ & $10.641 .948,84$ & & $\left(\sum_{2} X\right)^{2}$ & $12.562 .062,49$ \\
\hline Q1 & $27.579,28$ & & Q2 & $42.927,43$ \\
\hline $\mathrm{F}$ & 1,56 & & & \\
\hline $\mathrm{L}$ & 8 & & $L^{\prime}$ & 8 \\
\hline$s 2>s 1$ & $L=N 2-1$ & & & \\
\hline & $L^{\prime}=N 1-1$ & & & \\
\hline$F^{*} 8,8$ & 3,438 & & & \\
\hline
\end{tabular}

Como $F<F^{*} 8,8$ as variâncias são homogêneas

$t=1,00$

Valores de t no intervalo:

$\mathrm{t}^{\prime}=1,746$

$t^{*}=2,12$

$\mathrm{t}^{\prime *}=2,583$

$\mathrm{t}^{* *}=2,921$

$\mathrm{t}^{\star \star *}=4,015$

Portanto t' > t e a diferença não é significativa 
Tabela B7 - Comparação das médias de DQO efluente entre o período de 8-10 e 12-13 (dados de $2^{\text {a }}$ feira e $3^{\text {a }}$ feira agrupados).

\begin{tabular}{|c|c|c|c|c|}
\hline$n^{\circ}$ de amostras & 8 às 10 & 12 às 13 & $(8 \text { às } 10)^{2}$ & $(12 \text { às } 13)^{2}$ \\
\hline 1 & 320 & 379 & 102400 & 143641 \\
\hline 2 & 374 & 362 & 139726 & 130971 \\
\hline 3 & 325 & 364 & 105625 & 132496 \\
\hline 4 & 332 & 364 & 110224 & 132496 \\
\hline 5 & 320 & 289 & 102400 & 83521 \\
\hline 6 & 395 & 393 & 155946 & 154291 \\
\hline 7 & 492 & 384 & 242162 & 147148 \\
\hline 8 & 311 & 513 & 96534 & 263476 \\
\hline 9 & 394 & 340 & 154999 & 115328 \\
\hline$\Sigma$ & 3262,2 & 3387,2 & 1210018 & 1303371 \\
\hline média & 362,4667 & 376,3556 & & \\
\hline $\mathrm{DP}$ & 58,71465 & & DP & 59,770313 \\
\hline variância & 3447,41 & & variância & 3572,4903 \\
\hline$(\Sigma 1 X)^{2}$ & 10641949 & & $(\Sigma 2 X)^{2}$ & 11473124 \\
\hline Q1 & 27579,28 & & Q2 & 28579,922 \\
\hline $\mathrm{F}$ & 1,036282 & & & \\
\hline$L$ & 8 & & $\mathrm{~L}^{\prime}$ & 8 \\
\hline \multirow[t]{2}{*}{$s 2>s 1$} & $L=N 2-1$ & & & \\
\hline & $L^{\prime}=N 1-1$ & & & \\
\hline$F^{*} 8,8$ & 3,438 & & & \\
\hline
\end{tabular}

Como $\mathrm{F}<\mathrm{F}^{*} 8,8$ as variâncias são homogêneas

$t=0,497$

Valores de t no intervalo:

$\mathrm{t}^{\prime}=1,746$

$\mathrm{t}^{*}=2,12$

$\mathrm{t}^{\prime *}=2,583$

$\mathrm{t}^{* *}=2,921$

$\mathrm{t}^{* * *}=4,015$

Portanto t' > t e a diferença não é significativa. 
Tabela B8 - Comparação das médias de DQO efluente entre o período de 10-12 e 1213 (dados de $2^{\text {a }}$ feira e $3^{\text {a }}$ feira agrupados).

\begin{tabular}{|c|c|c|c|c|}
\hline $\mathrm{n}^{0}$ de amostras & 10 às 12 & 12 às 13 & $(10 \text { às } 12)^{2}$ & $(12 \text { às } 13)^{2}$ \\
\hline 1 & 393 & 379 & 154449 & 143641 \\
\hline 2 & 372 & 362 & 138309 & 130971 \\
\hline 3 & 377 & 364 & 142129 & 132496 \\
\hline 4 & 501 & 364 & 251001 & 132496 \\
\hline 5 & 310 & 289 & 96100 & 83521 \\
\hline 6 & 408 & 393 & 166790 & 154291 \\
\hline 7 & 515 & 384 & 265431 & 147148 \\
\hline 8 & 306 & 513 & 93819 & 263476 \\
\hline 9 & 362 & 340 & 130682 & 115328 \\
\hline$\Sigma$ & 3544,3 & 3387,2 & 1438712,15 & 1303371,46 \\
\hline média & 393,8111111 & 376,3556 & & \\
\hline $\mathrm{DP}$ & 73,25249901 & & DP & 59,77031268 \\
\hline variância & 5365,928611 & & variância & 3572,490278 \\
\hline$(\Sigma 1 X)^{2}$ & 12562062,49 & & $\left(\sum 2 X\right)^{2}$ & 11473123,84 \\
\hline Q1 & 42927,42889 & & Q2 & 28579,92222 \\
\hline $\mathrm{F}$ & 0,665772979 & & & \\
\hline $\mathrm{L}$ & 8 & & $L^{\prime}$ & 8 \\
\hline \multirow[t]{2}{*}{$\mathrm{s} 1>\mathrm{s} 2$} & $L=N 1-1$ & & & \\
\hline & $L^{\prime}=N 2-1$ & & & \\
\hline$F * 8,8$ & 3,438 & & & \\
\hline
\end{tabular}

Como $\mathrm{F}<\mathrm{F}^{\star} 8,8$ as variâncias são homogêneas

$\mathrm{t}=0,55$

Valores de t no intervalo:

$\mathrm{t}^{\prime}=1,746$

$\mathrm{t}^{*}=2,12$

$\mathrm{t}^{\prime *}=2,583$

$t^{* *}=2,921$

$t^{* * *}=4,015$

Portanto t' > t e a diferença não é significativa. 
ANEXO C - Teste de Atividade Metanogênica Específica. 
Tabela $\mathrm{C} 1$ - Teste de atividade metanogênica do inóculo utilizando esgoto como substrato.

\begin{tabular}{|r|r|r|r|r|r|r|}
\hline $\begin{array}{l}\text { Tempo } \\
\text { (dias) }\end{array}$ & $\begin{array}{l}\text { Área } \\
\text { (mmol) }\end{array}$ & $\mathrm{molCH}_{4}$ & \multicolumn{1}{l|}{$\mathrm{LCH}_{4}$} & gDQOcons & gDQOcons/gSsV & ACUMgDQOcons/gSsV \\
\hline 0,00 & 559 & $-0,00107$ & $-0,0239$ & & & \\
\hline 0,03 & 1755 & $-0,0009$ & $-0,02026$ & & & \\
\hline 0,05 & 3433 & $-0,00068$ & $-0,01515$ & & & \\
\hline 0,06 & 4085 & $-0,00059$ & $-0,01316$ & & & \\
\hline 0,08 & 6099 & $-0,00031$ & $-0,00703$ & & & \\
\hline 0,09 & 7551 & $-0,00012$ & $-0,00261$ & & & \\
\hline 0,12 & 10256 & 0,000251 & 0,005628 & 0,0133363 & 0,002883519 & 0,002883519 \\
\hline 0,14 & 12543 & 0,000562 & 0,012592 & 0,029839 & 0,006451682 & 0,009335201 \\
\hline 0,18 & 14775 & 0,000866 & 0,019389 & 0,0459449 & 0,009934034 & 0,019269235 \\
\hline 0,20 & 20899 & 0,001698 & 0,038037 & 0,0901351 & 0,019488661 & 0,038757897 \\
\hline 0,26 & 23765 & 0,002088 & 0,046764 & 0,1108158 & 0,023960176 & 0,062718073 \\
\hline 0,30 & 34121 & 0,003496 & 0,078299 & 0,1855436 & 0,040117543 & 0,102835616 \\
\hline 0,34 & 29227 & 0,00283 & 0,063397 & 0,150229 & 0,032481955 & 0,135317571 \\
\hline 0,36 & 30093 & 0,002948 & 0,066034 & 0,156478 & 0,033833082 & 0,169150653 \\
\hline
\end{tabular}

Tabela C2 - Teste de atividade metanogênica do inóculo utilizando acetato como substrato.

\begin{tabular}{|r|r|r|r|r|r|r|}
\hline Tempo (dias) & $\begin{array}{l}\text { Área } \\
\text { (mmol) }\end{array}$ & $\mathrm{molCH}_{4}$ & $\mathrm{LCH}_{4}$ & gDQOcons & gDQOcons/gSsV & ACUMgDQOcons/gSSV \\
\hline 0,00 & 917 & $-0,00102$ & $-0,02281$ & & & \\
\hline 0,03 & 6115 & $-0,00031$ & $-0,00698$ & & & \\
\hline 0,05 & 10599 & 0,000298 & 0,006672 & 0,0158113 & 0,001699229 & 0,001699229 \\
\hline 0,06 & 12566 & 0,000565 & 0,012662 & 0,030005 & 0,00322461 & 0,004923839 \\
\hline 0,08 & 20972 & 0,001708 & 0,038259 & 0,0906618 & 0,009743344 & 0,014667183 \\
\hline 0,09 & 27458 & 0,00259 & 0,05801 & 0,1374641 & 0,014773146 & 0,029440329 \\
\hline 0,12 & 38625 & 0,004108 & 0,092015 & 0,218044 & 0,023432996 & 0,052873325 \\
\hline 0,14 & 47889 & 0,005367 & 0,120224 & 0,2848921 & 0,030617098 & 0,083490423 \\
\hline 0,17 & 54419 & 0,006255 & 0,140109 & 0,3320119 & 0,035681021 & 0,119171444 \\
\hline 0,21 & 67634 & 0,008051 & 0,18035 & 0,42737 & 0,045929066 & 0,16510051 \\
\hline 0,26 & 92069 & 0,011373 & 0,254757 & 0,6036904 & 0,064878064 & 0,229978574 \\
\hline 0,30 & 134477 & 0,017138 & 0,383894 & 0,9097021 & 0,097764869 & 0,327743443 \\
\hline 0,34 & 117394 & 0,014816 & 0,331875 & 0,786433 & 0,084517244 & 0,412260687 \\
\hline 0,37 & 122948 & 0,015571 & 0,348787 & 0,82651 & 0,088824293 & 0,50108498 \\
\hline
\end{tabular}


Tabela C3 - Teste de atividade metanogênica do leito de lodo, utilizando esgoto como substrato.

\begin{tabular}{|r|r|r|r|r|r|r|}
\hline $\begin{array}{l}\text { Tempo } \\
\text { (dias) }\end{array}$ & $\begin{array}{l}\text { Área } \\
(\mathrm{mmol})\end{array}$ & $\mathrm{molCH}_{4}$ & $\mathrm{LCH}_{4}$ & gDQOcons & gDQOcons/gSSV & ACUMgDQOcons/gSSV \\
\hline 0,00 & 0 & $-0,00057$ & $-0,0128$ & & & \\
\hline 0,04 & 3205 & $-0,00071$ & $-0,01584$ & & & \\
\hline 0,08 & 0 & $-0,00114$ & $-0,0256$ & & & \\
\hline 0,15 & 2553 & $-0,0008$ & $-0,01783$ & & & \\
\hline 0,21 & 6150 & $-0,00031$ & $-0,00688$ & & & \\
\hline 0,27 & 9259 & 0,000116 & 0,002592 & 0,00614203 & 0,000699787 & 0,000699787 \\
\hline 0,29 & 12742 & 0,000589 & 0,013198 & 0,03127499 & 0,00356329 & 0,004263076 \\
\hline 0,48 & 29945 & 0,002928 & 0,065583 & 0,15541005 & 0,017706512 & 0,021969588 \\
\hline 0,63 & 33778 & 0,003449 & 0,077255 & 0,18306858 & 0,020857763 & 0,042827351 \\
\hline 0,67 & 36769 & 0,003855 & 0,086363 & 0,20465133 & 0,023316774 & 0,066144125 \\
\hline 0,71 & 40937 & 0,004422 & 0,099055 & 0,23472718 & 0,026743441 & 0,092887566 \\
\hline 0,75 & 48183 & 0,005407 & 0,12112 & 0,28701357 & 0,032700646 & 0,125588212 \\
\hline 0,79 & 43634 & 0,004789 & 0,107268 & 0,25418846 & 0,028960745 & 0,154548957 \\
\hline 0,88 & 49966 & 0,00565 & 0,126549 & 0,29987951 & 0,034166516 & 0,188715473 \\
\hline 0,92 & 53337 & 0,006108 & 0,136814 & 0,3242043 & 0,03693794 & 0,225653412 \\
\hline 1,00 & 63906 & 0,007545 & 0,168998 & 0,4004691 & 0,045627105 & 0,271280518 \\
\hline 1,08 & 59055 & 0,006885 & 0,154226 & 0,36546479 & 0,041638919 & 0,312919436 \\
\hline 1,17 & 62615 & 0,007369 & 0,165067 & 0,39115338 & 0,044565726 & 0,357485163 \\
\hline 1,21 & 72742 & 0,008746 & 0,195905 & 0,46422876 & 0,052891507 & 0,41037667 \\
\hline 1,71 & 45849 & 0,00509 & 0,114012 & 0,27017167 & 0,030781778 & 0,441158448 \\
\hline
\end{tabular}

Tabela C4 - Teste de atividade metanogênica do leito de lodo, utilizando acetato como substrato.

\begin{tabular}{|r|r|r|r|r|r|r|}
\hline $\begin{array}{l}\text { Tempo } \\
\text { (dias) }\end{array}$ & $\begin{array}{l}\text { Área } \\
\text { (mmol) }\end{array}$ & $\mathrm{molCH}_{4}$ & $\mathrm{LCH}_{4}$ & gDQOcons & gDQOcons/gSSV & ACUMgDQOcons/gSSV \\
\hline 0,00 & 0 & $-0,00057$ & $-0,0128$ & & & \\
\hline 0,00 & 0 & $-0,00114$ & $-0,0256$ & & & \\
\hline 0,04 & 918 & $-0,00102$ & $-0,02281$ & & & \\
\hline 0,10 & 5868 & $-0,00035$ & $-0,00773$ & & & 0,003869339 \\
\hline 0,17 & 15131 & 0,000914 & 0,020473 & 0,0485138 & 0,003869339 & 0,0106842 \\
\hline 0,23 & 20249 & 0,00161 & 0,036058 & 0,0854447 & 0,006814861 & 0,021908711 \\
\hline 0,25 & 27911 & 0,002651 & 0,059389 & 0,1407329 & 0,011224511 & 0,053572314 \\
\hline 0,44 & 63425 & 0,007479 & 0,167533 & 0,3969983 & 0,031663603 & 0,092417282 \\
\hline 0,58 & 75903 & 0,009175 & 0,20553 & 0,4870382 & 0,038844968 & 0,134366041 \\
\hline 0,63 & 81296 & 0,009909 & 0,221952 & 0,5259535 & 0,041948759 & 0,180088498 \\
\hline 0,67 & 87853 & 0,0108 & 0,241919 & 0,5732682 & 0,045722457 & 0,228281671 \\
\hline 0,71 & 92146 & 0,011384 & 0,254992 & 0,604246 & 0,048193174 & 0,278422411 \\
\hline 0,75 & 95530 & 0,011844 & 0,265296 & 0,6286646 & 0,05014074 & 0,336949084 \\
\hline 0,83 & 110101 & 0,013824 & 0,309667 & 0,7338074 & 0,058526673 & 0,400283093 \\
\hline 0,88 & 118454 & 0,01496 & 0,335103 & 0,7940818 & 0,063334009 & 0,474383394 \\
\hline 0,96 & 137161 & 0,017503 & 0,392067 & 0,9290696 & 0,074100301 & 0,552380556 \\
\hline 1,04 & 143932 & 0,018423 & 0,412686 & 0,9779284 & 0,077997161 & 0,641652195 \\
\hline 1,13 & 163522 & 0,021087 & 0,472339 & 1,1192878 & 0,089271639 & 0,72878692 \\
\hline 1,17 & 159809 & 0,020582 & 0,461033 & 1,0924952 & 0,087134726 & \\
\hline 1,67 & 140073 & 0,017899 & 0,400935 & 0,9500823 & 0,075776221 & \\
\hline
\end{tabular}


ANEXO D - Adensamento do lodo do UASB. 
Tabela D1 - Adensamento do lodo a $0,25 \mathrm{~m}, 0,85 \mathrm{~m}$ e $1,45 \mathrm{~m}$ ao longo do tempo.

\begin{tabular}{|c|c|c|c|c|c|c|c|c|c|c|}
\hline \multirow{2}{*}{ Data } & \multirow{2}{*}{ Dia } & \multicolumn{3}{|c|}{$0,25 \mathrm{~m}$} & \multicolumn{3}{|c|}{$0,85 \mathrm{~m}$} & \multicolumn{3}{|c|}{$1,45 \mathrm{~m}$} \\
\hline & & STV & ST & STVIST & STV & ST & STVIST & STV & ST & STV/ST \\
\hline $21 / 2 / 2006$ & 12 & & & & 757 & 2.007 & $38 \%$ & 864 & 2.366 & $37 \%$ \\
\hline $6 / 3 / 2006$ & 33 & 90 & 1.500 & $6 \%$ & 1.053 & 1.697 & $62 \%$ & 2.988 & 5.642 & $53 \%$ \\
\hline $22 / 3 / 2006$ & 47 & & & & & & & 303 & 445 & $68 \%$ \\
\hline $29 / 3 / 2006$ & 54 & 371 & 563 & $66 \%$ & 276 & 473 & $58 \%$ & 294 & 436 & $67 \%$ \\
\hline $10 / 4 / 2006$ & 68 & 17.103 & 27.640 & $62 \%$ & 453 & 663 & $68 \%$ & 476 & 689 & $69 \%$ \\
\hline $26 / 4 / 2004$ & 82 & 19.587 & 30.445 & $64 \%$ & 570 & 1.112 & $51 \%$ & 513 & 988 & $52 \%$ \\
\hline $18 / 7 / 2006$ & 162 & 23.185 & 33.708 & $69 \%$ & 386 & 491 & $78 \%$ & 314 & 465 & $67 \%$ \\
\hline $2 / 8 / 2006$ & 176 & 18.633 & 26.926 & $69 \%$ & 287 & 628 & $46 \%$ & 409 & 589 & $69 \%$ \\
\hline $22 / 8 / 2006$ & 197 & 13.907 & 18.849 & $74 \%$ & 329 & 501 & $66 \%$ & 280 & 439 & $64 \%$ \\
\hline $4 / 9 / 2006$ & 204 & 14.973 & 20.200 & $74 \%$ & 13.988 & 19.260 & $73 \%$ & 420 & 740 & $57 \%$ \\
\hline $26 / 9 / 2006$ & 218 & 27.683 & 41.823 & $66 \%$ & 11.945 & 19.221 & $62 \%$ & 11.106 & 18.284 & $61 \%$ \\
\hline $2 / 10 / 2006$ & 225 & 23.559 & 33.578 & $70 \%$ & 10.716 & 15.054 & $71 \%$ & 10.403 & 14.825 & $70 \%$ \\
\hline $17 / 10 / 2006$ & 240 & 24.514 & 36.696 & $67 \%$ & 13.445 & 19.665 & $68 \%$ & 9.945 & 14.764 & $67 \%$ \\
\hline $30 / 10 / 2006$ & 253 & 24.205 & 36.328 & $67 \%$ & 13.014 & 19.485 & $67 \%$ & 12.761 & 19.011 & $67 \%$ \\
\hline $6 / 11 / 2006$ & 259 & 25.223 & 38.558 & $65 \%$ & 12.621 & 19.070 & $66 \%$ & 12.339 & 18.551 & $67 \%$ \\
\hline $13 / 11 / 2006$ & 266 & 23.926 & 36.559 & $65 \%$ & 12.759 & 19.785 & $64 \%$ & 12.191 & 18.764 & $65 \%$ \\
\hline
\end{tabular}

